\title{
Hot Rocks from Cold Places: A Field, Geochemical and Geochronological Study from the High Arctic Large Igneous Province (HALIP) at Axel Heiberg Island, Nunavut
}

\author{
by
}

\section{Cole Girard Kingsbury}

A thesis submitted to the Faculty of Graduate and Postdoctoral Affairs in partial fulfillment of the requirements for the degree of

Doctor of Philosophy

in

Earth Sciences

\author{
Ottawa - Carleton Geoscience Centre \\ and \\ Carleton University \\ Ottawa, Ontario
}

(C) 2016

Cole Girard Kingsbury 


\section{Abstract:}

The geology of the Arctic is greatly influenced by a period of widespread Cretaceous magmatic activity, the High Arctic Large Igneous Province (HALIP). Two major tholeiitic magmatic pulses characterize HALIP: an initial 120 -130 Ma pulse that affected Arctic Canada and formally adjacent regions of Svalbard (Norway) and Franz Josef Land (Russia). In Canada, this pulse fed lava flows of the Isachsen Formation. A second 90-100 Ma pulse that apparently only affected the Canadian side of the Arctic, fed flood basalts of the Strand Fiord Formation.

The goal of this thesis is to improve understanding of Arctic magmatism of the enigmatic HALIP through field, remote sensing, geochemical and geochronology investigations of mafic intrusive rocks collected in the South Fiord area of Axel Heiberg Island, Nunavut, and comparison with mafic lavas of the Isachsen and Strand Fiord Formations collected from other localities on the Island.

Ground-based and remote sensing observations of the South Fiord area reveal a complex network of mafic sills and mainly SSE-trending dykes. Two new U-Pb baddeleyite ages of $95.18 \pm 0.35 \mathrm{Ma}$ and $95.56 \pm 0.24 \mathrm{Ma}$ from South Fiord intrusions along with geochemical similarity confirm these intrusions (including the SSE-trending dykes) are feeders for the Strand Fiord Formation lavas. The ages constrain a $3 \mathrm{Ma}$ transition between the two pulses of older tholeiitic and the younger stage of alkaline magmatism that begins with the $92 \mathrm{Ma}$ Wootton Igneous Complex.

Based on trace element and Sm-Nd isotopic data, this 95 Ma pulse of South Fiord intrusives and Strand Fiord Formation lavas are derived from a homogenous upper mantle source that was crustally contaminated by sedimentary rocks of the Sverdrup Basin. In contrast, lavas of the older c. 120-130 Ma Isachsen Formation are derived from a heterogeneous mantle source and experienced significantly less crustal contamination. The mantle heterogeneity of lavas in the Isachsen Formation is probably defined in part by mantle melting that incorporated sediments from paleosubduction fronts ancestral to the Aleutian subduction zone. Furthermore, major element concentrations may also suggest contamination by evaporite diapirs from the Carboniferous Otto Fiord Formation. 


\section{Acknowledgements:}

\section{"It takes a village to raise a Child"}

$\sim$ African Proverb

\section{"It takes a community to intellectually raise a PhD student"}

$\sim$ Paraphrased from above

A Doctor of Philosophy degree is a massive undertaking that takes a community of dedicated individuals guiding aspiring students such as myself through the hoops and milestones even though only one name - mine - appears on the cover of this thesis. Firstly, I would like to thank Drs. Richard Ernst and Brian Cousens for playing a big game of chance 4 years ago in accepting me as their $\mathrm{PhD}$ student, being very supportive while also maintaining high expectations. I thank them greatly for helping me through this monumental project from start to end, sharing a wealth of knowledge in the fields of igneous geochemistry and large igneous provinces (LIPs) as well as unwittingly being "honorary Professors of Cole Management" in the last weeks of this degree journey.

I would also like to thank Dr. Marie-Claude Williamson of the Geological Survey of Canada (GSC) for serving on my advisory committee and taking me on a field season on Axel Heiberg Island in part to help me with the field component of my project, setting me straight when required, as well as providing additional samples from her $\mathrm{PhD}$ thesis in order to supplement my thesis samples. In addition, I thank Dr. Steve Bergman of Shell -a generous and enthusiastic project sponsor - for his help in reviewing thesis chapters as well as lending his expertise on Arctic geology pertaining to HALIP.

I also want to thank Rick McNeil and Steve Day (GSC team members who also were field members in 2013) for their company on Axel Heiberg Island during the 2013 field campaign and Gerry for skillful helicopter piloting and the company he provided during the extra days on the Island due to "Lowey" the low-pressure system. In addition I thank Jeff Harris for assistance in the remote sensing aspect of my work presented herein.

Processing samples both for geochemical, isotopic and $\mathrm{U}-\mathrm{Pb}$ age analysis took up the better part of my time in the middle years of this project, what I call the "dartthrowing" phase. I want to thank Tim Mount for assistance in teaching me how to use the 
rock saw, "blender," and "Alvin" along with making my thin sections and the discussions about sample preparation process. Furthermore, I thank Etienne Menard and Matt Hanewitch for help in sample processing. Thanks to Dr. Shuangquan Zhang for help in guiding me through the process of turning rock powder into excellent $\mathrm{Sm}-\mathrm{Nd}$ isotopic data including sample dissolution, ion exchange chromatography and mass-spectrometer loading and measurements. I also acknowledge Peter Jones in the microprobe lab here at Carleton University for helping me search for baddelyites in diabasic and gabbroic samples, Dr. Ulf, Soderlund at Lund University (Sweden) for separating these and Dr. Sandra Kamo (Jack Satterly geochronology lab, University of Toronto) for obtaining high quality $\mathrm{U}-\mathrm{Pb}$ ages based on baddeleyites along with assistance in data interpretation.

Finally I pay loads of thanks to Sonia Tanguay for being my Paul Menton Centre disability coordinator along with all the meetings we have had together in the last 4 years which helped me process emotions and thoughts and taught me that the sky is still up in the sky. In addition, I thank all of my fellow graduate students past and present in the LIPs and geochemistry research community for their camaraderie, help and support including Chris Rogers, Niko Kastek, Sarah Davey, Susan Kingdon, Dr. Ann Timmermans, Kim Klausen and Matthew Trenkler.

Last but not least, I want to thank my friends and family back home in Oregon including my parental units Steve and Diane as well as friends at " 16 1 12 Hour Fitness" and from KindTree Productions - Autism Rocks for their friendships and support from afar: this thesis is dedicated to them all and to all students presently writing their own thesis knowing that the journey to a complete thesis is a struggle - I salute you.

This thesis was supported financially through an NSERC CRD Grant (CRDPJ 419503-11) to Dr. Richard Ernst, the Polar Continental Shelf Program (PCSP), the Geological Survey of Canada Environmental Geoscience project, a Geological Society of America Research Grant as well as a departmental scholarship.

\section{I count myself very lucky to be surrounded with very supportive people who can see beyond my Quirkiness.}




\section{Preface:}

\section{STATEMENT OF CONTRIBUTIONS:}

\section{Field and sample collections:}

I (Cole Kingsbury) conducted fieldwork in the South Fiord region of Axel

Heiberg Island, northern Canada, that involved documenting structural information about igneous intrusions and their relations with sedimentary rocks as well as making decisions about sample selection under the watchful eyes of Dr. Marie-Claude Williamson and Steven Day (both Geological Survey of Canada). I decided upon the general field area (South Fiord) in consultation with Dr. Marie-Claude Williamson but the specific field traversing area was determined on the spot largely by where snow was sufficiently melted to permit field traverses based on helicopter reconnaissance. The samples I collected from South Fiord were supplemented by archived samples collected by Dr. Marie-Claude Williamson in the Geodetic Hills and Camp Five Creek localities of Axel Heiberg Island initially for her $\mathrm{PhD}$ thesis. These archived samples were bequeathed to me at Dr. Williamson's decision for this thesis as a means for chemical comparisons.

\section{Geochemical processing:}

Once samples from South Fiord along with Dr. Williamson's archived samples arrived, I processed the South Fiord samples to thin section pucks and powder for majorand trace-element along with isotopic geochemistry. Assistants were hired to process Dr. Williamson's samples. Tim Mount (Carleton University) made standard and singlepolished thin sections on my specifications. On return of major- and trace element data from ALS Laboratories in North Vancouver, BC, I chose samples for Sm-Nd isotopic analysis. I weighed and dissolved spiked powders with the spike provided by Dr. Shuangquan Zhang (Carleton University). I then took each through ion exchange chromatography, and prepared and ran each through the TIMS (Thermal Ionization Mass Spectrometer) instrument at Carleton University under guidance from Dr. Shuangquan Zhang and Dr. Brian Cousens. 


\section{Geochronology processing:}

I selected the samples reported herein for $\mathrm{U}-\mathrm{Pb}$ dating based on locating baddeleyites via electron microprobe with assistance from Peter Jones (Carleton University). I then secured the three samples chosen in separate labeled bags and then handed each to Dr. Richard Ernst (Carleton University) for shipment to Dr. Ulf Söderlund (Lund University, Sweden) for baddeleyite separation. Dr. Söderlund then shipped baddeleyite separates from the two samples that yielded baddeleyites to Dr. Sandra Kamo (University of Toronto) for Isotope Dilution Thermal Ionization Mass Sprectrometer (ID-TIMS) U-Pb dating.

\section{Thesis and manuscript construction:}

Unless otherwise indicated, I drafted all figures herein presented. In addition I took the lead in the interpretation of data and their broader significance but benefited greatly from substantive discussions and reviews from Drs. Richard Ernst and Brian Cousens (Carleton University), Dr. Marie-Claude Williamson (Geological Survey of Canada) and Dr. Steven Bergman (Shell). All chapters and sections originate from me unless explicitly stated otherwise.

This thesis is a contribution constructed around three interrelated body chapters (Chapters 2-4) that are written in such a way that they each can be converted into scholarly works in peer-reviewed journals. Because of this structure, repetition in the chapter introductions is present but I have attempted to minimize such. Chapter 3 of this thesis is already published in the Norwegian Journal of Geology under the citation:

Kingsbury, C.G., Ernst, R.E., Cousens, B.L., and Williamson, M.-C., 2016, The High Arctic LIP in Canada: Trace element and Sm-Nd Isotopic evidence for the role of mantle heterogeneity and crustal assimilation: Norwegian Journal of Geology, v. 96, no. 2 p. $13-33$

With the exception of adding data and discussions on major element analysis as well as evaporite contamination in concert with minor stylistic alterations to fit the thesis format, 
all elements of the Norwegian Journal of Geology are included in Chapter 3. Norwegian Journal of Geology copyright policy (http://www.geologi.no/njg) maintains authors' original ownership of copyright under a Creative Commons Attribution 4.0 International license (https://creativecommons.org/licenses/by/4.0/). No copyright transfer occurred

\section{upon final acceptance.}

Chapters 2 and 4 are provisionally aimed for future publication in the Canadian Journal of Earth Sciences and Lithos, respectively, under my first-authorship.

\section{STATEMENT OF ORIGINALITY}

This thesis was born out of a need to fill gaps in understanding a major yet enigmatic episode of Cretaceous magmatic activity in Canada's High Arctic (High Arctic large igneous province; HALIP). Unlike geoscience knowledge in more temperate regions where access to outcrop can be via dirt roads, geoscience knowledge in Arctic regions suffers greatly from extreme inaccessibility coupled with short field seasons measured in terms of weeks when snow is sufficiently melted to permit direct observation of outcrop let alone basic access. As a result, a sizable swath of Arctic Canada lacks detailed ground-based mapping, along with the concomitant paucity of sample availability and analysis:

- Chapter 2: I mapped a geographically small but dense network of sills and dykes along with two lava flows that together were not previously mapped, based on foot traverses within the South Fiord region of Axel Heiberg Island, Nunavut complemented with modern remote sensing techniques.

- Chapter 3: Approximately 40 samples of mafic intrusive rocks derived from sills and dykes as well as a lava flow mapped in Chapter 2 are characterized via petrography, trace elements and $\mathrm{Nd}$ isotopes. These are then compared on a chemical basis with 19 samples derived from Isachsen Formation lava flows from Camp Five Creek and Geodetic Hills localities (also on Axel Heiberg Island). The 
knowledge gap this chapter fills is that these intrusions were affected by crustal contamination whereas the lava flows showed little contamination but evidence of potential subducted sediment derived from ancestral Aleutian and Alaska subduction zones and/or potential contamination from evaporite domes of the Otto Fiord Formation. The distinct petrogenetic histories of the South Fiord intrusions and Isachsen flows reflects their difference in age (c. 90-100 Ma vs c.125 Ma).

- Chapter 4: I link the first two precise U-Pb age determinations of intrusions mapped in the South Fiord locality to the Late Cretaceous Strand Fiord Formation lavas. Previously, the age of these flows were known only via stratigraphic, imprecise K-Ar and Ar-Ar methods. I then describe the significance that traceelement and isotope chemistry of the two age-determined samples have for (1) elucidating the number of magmatic injections within the South Fiord locality, (2) providing insight into the duration of the Strand Fiord Formation lavas, and (3) assessing the geometry of the plumbing system of the Strand Fiord Formation. 


\section{Table Of Contents:}

$\begin{array}{lr}\text { Abstract } & i i \\ \text { Acknowledgements } & i i i \\ \text { Preface } & v \\ \text { Table of Contents } & i x \\ \text { List of Tables } & x i i \\ \text { List of Figures } & x i i i \\ \text { List of Appendixes } & x v\end{array}$

\section{Chapter 1:}

Introduction to the Thesis

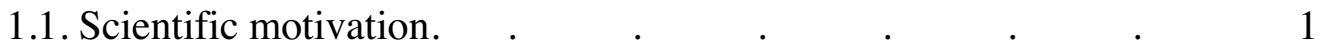

1.2. Bathymetry and evolution of the Arctic basin. . . . 2

1.3. Sverdrup Basin . $\quad . \quad$. $\quad . \quad$. $\quad . \quad$. 5

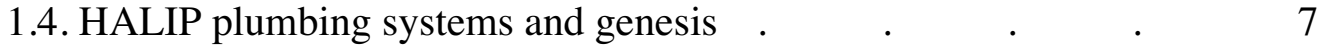

1.5. The Isachsen Formation . $\quad . \quad$. $\quad$. $\quad$. $\quad$. 11

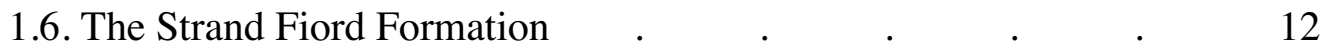

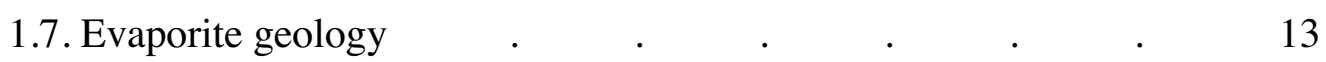

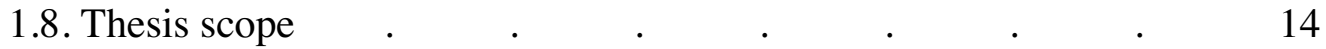

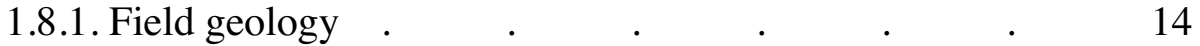

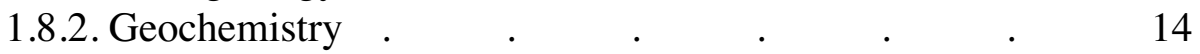

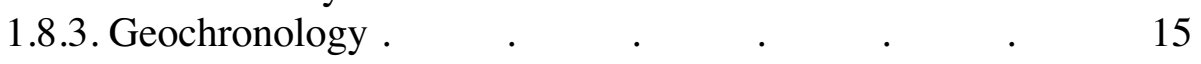

1.8.4. Thesis objectives and structure. $\quad . \quad$. $\quad . \quad 18$

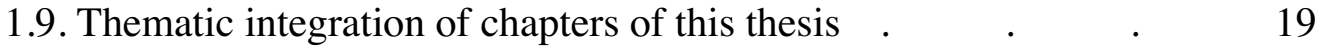

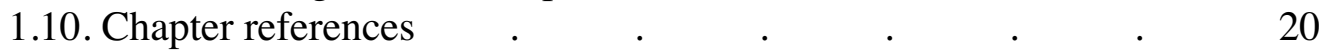

\section{Chapter 2:}

Field mapping and remote sensing of mafic igneous structures in the South Fiord locality, Axel Heiberg Island, Nunavut

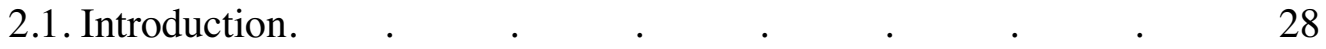

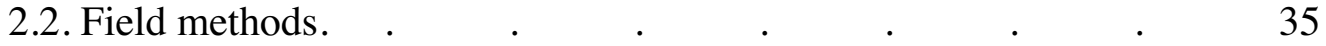

2.3. Field characteristics $\quad . \quad$. $\quad . \quad$. $\quad . \quad$. 36

2.4. Remote sensing for geologic mapping . . . . . . . $\quad$. 44

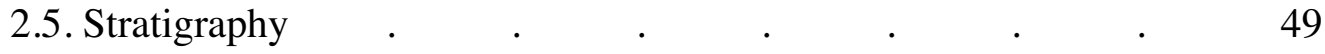

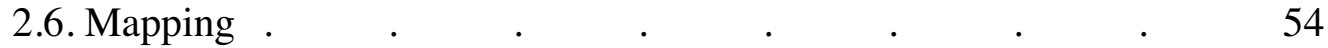

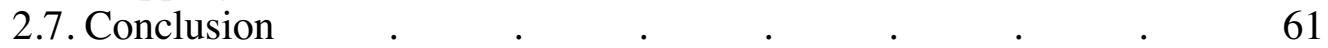

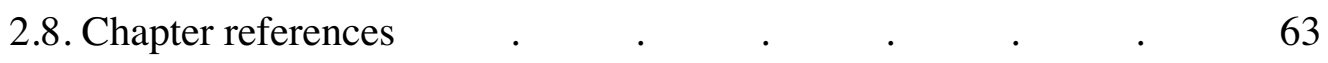




\section{Chapter 3:}

Major, trace element and Sm-Nd Isotopic evidence for the role of mantle heterogeneity and crustal assimilation in HALIP from South Fiord, Geodetic Hills and Camp Five Creek, Axel Heiberg Island.

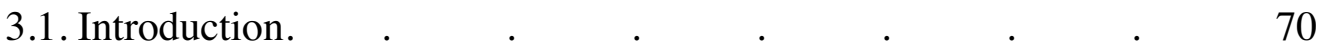

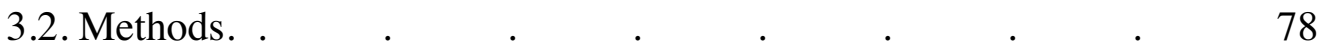

3.2.1. Field and sampling methods $\quad . \quad$.

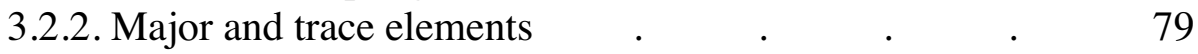

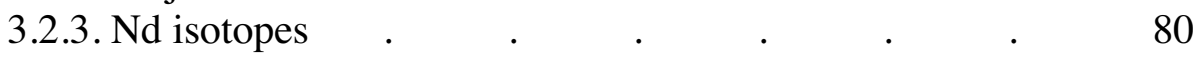

3.3. Results.

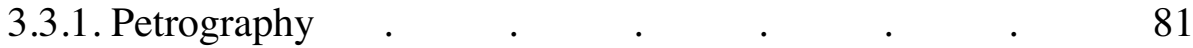

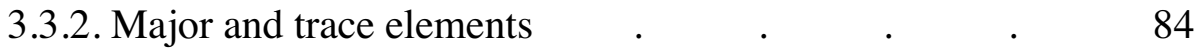

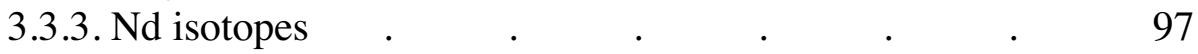

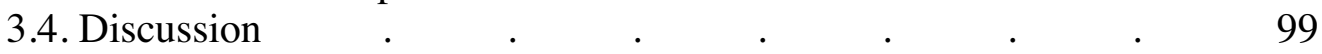

3.4.1. Mantle plume head as the driver for the HALIP . $\quad 102$

3.4.2. Crustal assimilation . . . . . . . . 103

3.4.3. Crustal assimilation modeling assumptions . . . 104

3.4.4. Two component mixing . . . . . $\quad$. 106

3.4.5. Crustal interaction levels $\quad . \quad$. $\quad . \quad$. $\quad . \quad 110$

3.4.6. Subducted sediment as a driver for mantle heterogeneity? 111

3.4.7. Alternative model of interaction with evaporite . 116

3.4.8. Crustal influences on Strand Fiord and Isachsen Formation

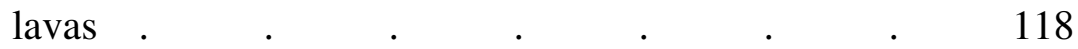

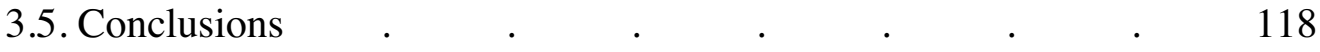

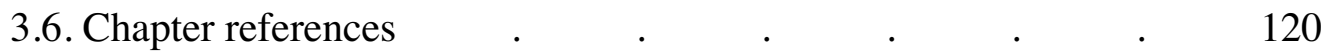

\section{Chapter 4:}

U-Pb Geochronology of the HALIP from Axel Heiberg Island in Nunavut, Canada: implications for magmatic evolution of the Strand

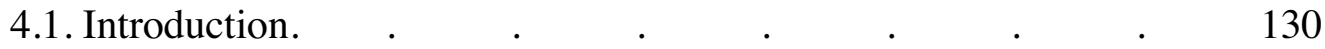

4.1.1. Chapter introduction and scope $\quad . \quad$. $\quad . \quad 130$

4.1.2. The Strand Fiord Formation . $\quad$. $\quad$. $\quad$. 130

4.1.3. Chronostratigraphy . . . . . . . . . $\quad$. 131

4.1.3. Review of previous geochronology $\quad . \quad$. $\quad . \quad$. 133

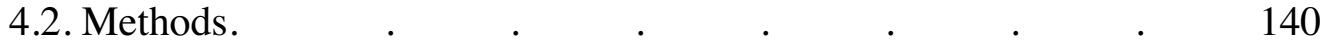

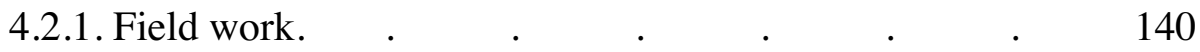

4.2.2. Sample selection and processing _ . . . . $\quad$. 142

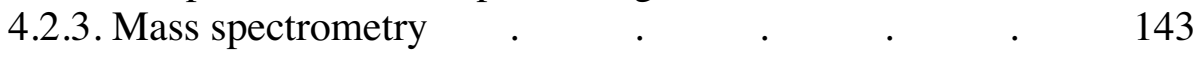

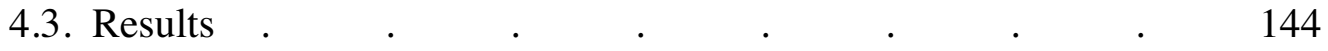

4.3.1. Sample and collection site description . $\quad$. $\quad$. 144

4.3.1.1. Sample 13-CK-16 . . . . . . 144 
4.3.1.2. Sample 13-WJA-C028-A2 . . . $\quad 144$

4.3.2. Baddeleyite morphology and characteristics . . 146

4.3.3. U-Pb geochronology . $\quad$. $\quad$. $\quad$. $\quad . \quad 149$

4.3.3.1. Sample 13-CK-16 . . . . . $\quad$. 149

4.3.3.2. Sample 13-WJA-C028-A2 . $\quad$. $\quad$. 149

4.4. Discussion . . . . . . . $\quad . \quad . \quad 151$

4.4.1. Magmatic evolution of the HALIP . . . . 152

4.4.2. Nature of magmatism in South Fiord . . . . 152

4.4.3. Duration of the Strand Fiord Formation 154

4.4.4. Relations to underlying magmatic intrusion . . $\quad 156$

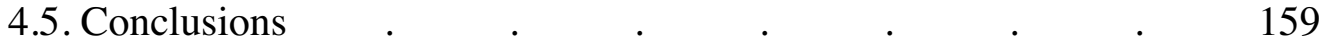

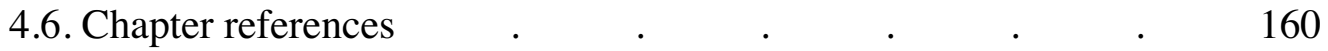

\section{Chapter 5:}

Conclusions

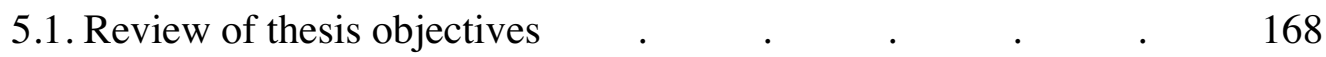

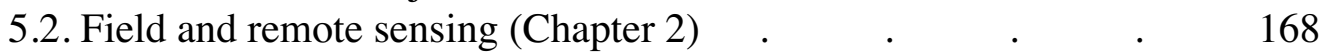

5.3. Geochemistry and Sm-Nd isotopes (Chapter 3) . $\quad$. $\quad 169$

5.4. U-Pb geochronology (Chapter 4) . . . . . . . 172

5.5. Demonstrated integration. . . . . . . . . 173

$\begin{array}{llllllllll}5.6 . & \text { Chapter references } & \text {. } & \text {. } & \text {. } & \text {. } & \text {. } & \text {. } & & 174\end{array}$ 


\section{List of Tables:}

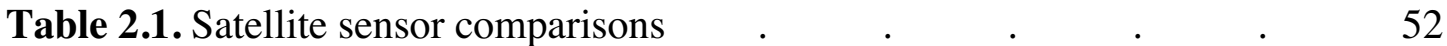

Table 2.2. Characteristics of select mafic units in South Fiord area . $\quad$. 61

Table 4.1. Representative Ar-Ar and K-Ar age determinations . $\quad$. 135

Table 4.2. U-Pb age determinations of HALIP in order of age $\quad$. $\quad$. 137 


\section{List of Figures:}

Note: In situations where figure captions are on the preceding page of the figure it describes, the page number listed is where the actual figure may be found.

Figure 1.1. Arctic bathymetry

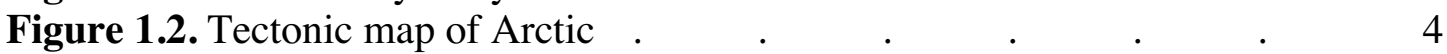

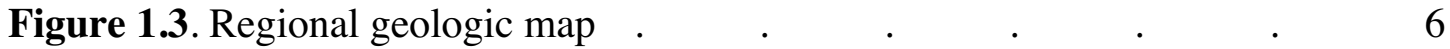

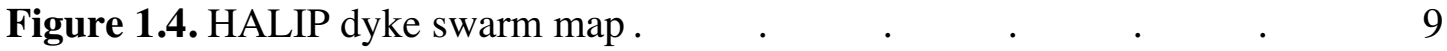

Figure 1.5. HALIP lavas and plumbing system map . $\quad . \quad$. $\quad$. 10

Figure 1.6. Age spectrum "barcode" diagram of previous U-Pb HALIP ages 17

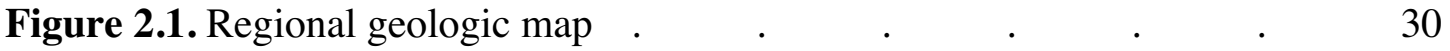

Figure 2.2. Enhanced Landsat imagery of Strand Fiord - Expedition Fiord . $\quad 31$

Figure 2.3. Geologic map of Thorsteinsson and Tozer (1971) . $\quad$. 33

Figure 2.4. Modified geologic map of Jackson and Harrison (2010) . 34

Figure 2.5. Digital elevation model map of South Fiord . $\quad$. $\quad$. 37

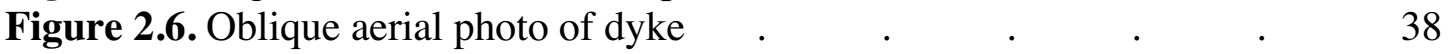

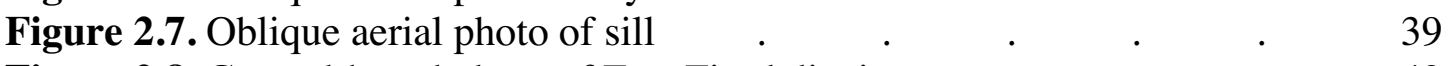

Figure 2.8. Ground-based photo of East Fiord diapir $\quad$. $\quad$. $\quad$. 40

Figure 2.9. True colour Landsat 7 image of South Fiord area $\quad$. $\quad$. 44

Figure 2.10. True colour ASTER image of South Fiord area $\quad$. $\quad$. 45

Figure 2.11. True colour SPOT-6 image of portion of South Fiord . $\quad$. 46

Figure 2.12. Topographic map of foot traverse area with sample sites $\quad$. $\quad 47$

Figure 2.13. Comparative satellite imagery of Cuesta Ridge $\quad$. $\quad$. 50

Figure 2.14. Ground based photo of Cuesta Ridge . $\quad$. $\quad$. $\quad$. 51

Figure 2.15. Cuesta Ridge stratigraphic profile $\quad . \quad$. $\quad . \quad$. 53

$\begin{array}{llll}\text { Figure 2.16. Three field photos of foot traverse area . } \quad . \quad & \text {. } & 57\end{array}$

Figure 2.17. Geologic geologic map from SPOT-imagery . $\quad$ • $\quad$. 59

Figure 2.18. Cartoon cross-section of South Fiord field locality ， . $\quad 60$

Figure 3.1. Pan-Arctic HALIP map . $\quad . \quad$. $\quad$. $\quad . \quad$. $\quad$. 71

Figure 3.2. Outline map of the Sverdrup Basin $\quad . \quad$. $\quad$. $\quad$. 73

Figure 3.3. Cretaceous Sverdrup Basin stratigraphic sequence $\quad$. $\quad$. 74

Figure 3.4. Maps of Axel Heiberg Island and South Fiord . $\quad$. $\quad$. 77

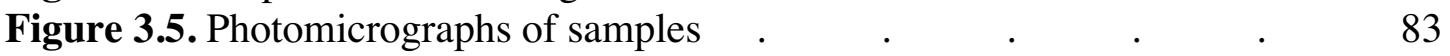

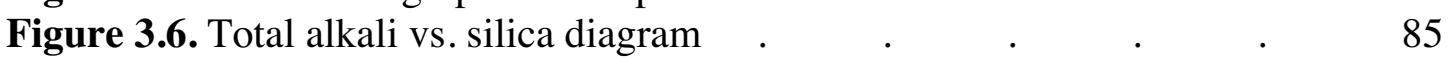

Figure 3.7. Total alkali - Fe - Mg (AFM) ternary plot $\quad$. $\quad . \quad$. $\quad$. $\quad 85$

Figure 3.8. $\mathrm{SiO}_{2}$ vs. major element Harker diagrams $\quad$. $\quad$. $\quad$. $\quad 86$

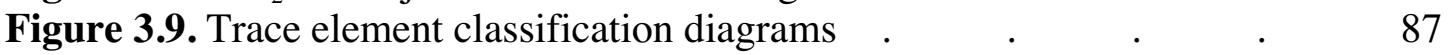

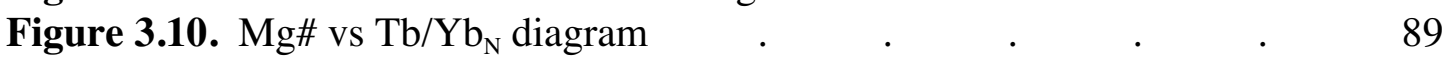

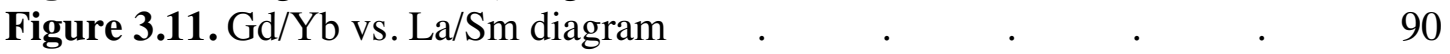

Figure 3.12. Chondrite-normalized REE diagram . $\quad$. $\quad . \quad$. $\quad$. 91

Figure 3.13. Primitive-mantle normalized trace element diagram . $\quad$. 93

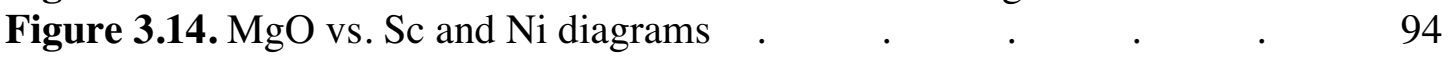




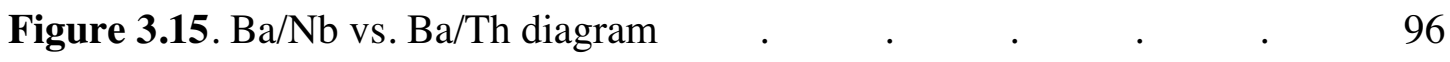

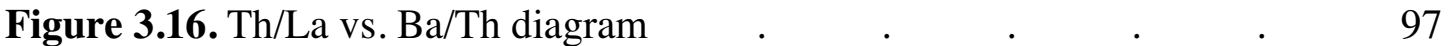

Figure 3.17. $\mathrm{Sm} / \mathrm{Nd}$ whole rock errorchron diagram . $\quad . \quad$. $\quad$. $\quad 99$

Figure 3.18. $\mathrm{Mg \#}$ vs. $\varepsilon \mathrm{Nd}_{\mathrm{t}}$ diagram . $\quad$. $\quad . \quad$. $\quad . \quad$. $\quad 104$

Figure 3.19. Two-component mixing $\mathrm{Th} / \mathrm{La}$ vs $\varepsilon \mathrm{Nd}_{\mathrm{t}}$ diagram $\quad . \quad$. 107

Figure 3.20. Two-component mixing $\mathrm{Nb} / \mathrm{U}$ vs. $\varepsilon \mathrm{Nd}_{\mathrm{t}}$ diagram $\quad . \quad$. 108

Figure 3.21. Two-component mixing $\mathrm{Ba} / \mathrm{Nb}$ vs. $\varepsilon \mathrm{Nd}_{\mathrm{t}}$ diagram $\quad$. $\quad$. 109

Figure 3.22. Two-component mixing $\mathrm{Ba} / \mathrm{Nb}$ vs. $\mathrm{Ba} / \mathrm{Th}$ diagram . $\quad$. 114

Figure 3.23. Silica vs. $\mathrm{CaO}$ diagram . $\quad . \quad$. $\quad . \quad$. $\quad$. 117

Figure 4.1. Cretaceous Sverdrup Basin stratigraphic sequence $\quad$ • $\quad$. 132

Figure 4.2. Outline map of Sverdrup Basin . $\quad . \quad$. $\quad . \quad$. $\quad 134$

Figure 4.3. U-Pb age "barcode" of HALIP . $\quad . \quad$. $\quad . \quad$. 138

Figure 4.4. Pan-Arctic HALIP map . $\quad$. $\quad$. $\quad$. $\quad$. $\quad$. 141

Figure 4.5. South Fiord geologic map with sample locations $\quad$. $\quad$. 145

Figure 4.6. Sample 13-CK-16 baddeleyite images . . . . . . . 147

Figure 4.7. Sample 13-WJA-C028-A2 baddeleyite images . . . 148

Figure 4.8. Sample 13-CK-16 U-Pb concordia diagram . . . $\quad$. 150

Figure 4.9. Sample 13-WJA-C028-A2 U-Pb concordia diagram . $\quad$. 150

Figure 4.10. Weighted mean U-Pb age diagram $\quad . \quad$. $\quad$. $\quad$. 151

Figure 4.11. $\mathrm{Mg \#}$ vs. $\varepsilon \mathrm{Nd}_{\mathrm{t}}$ diagram with batches . $\quad . \quad$. $\quad . \quad 154$

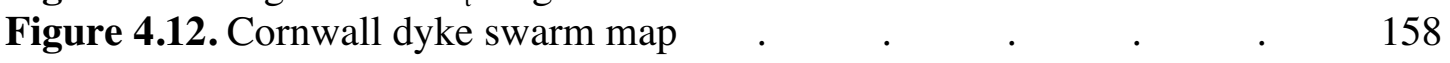




\section{List of Appendixes:}

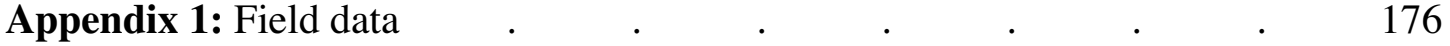

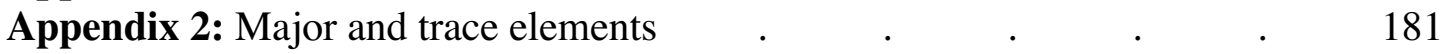

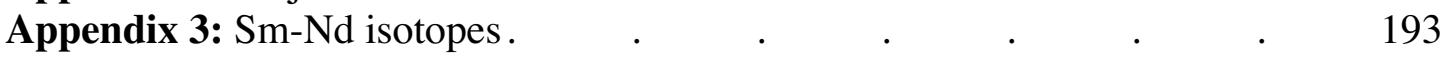

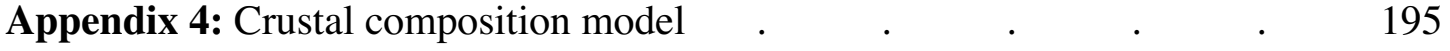

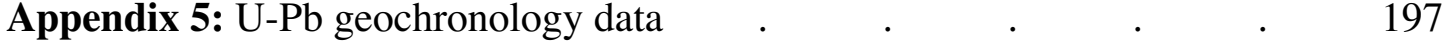

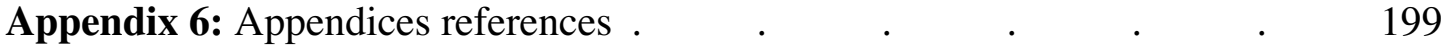




\section{Chapter 1: \\ Introduction to the thesis}

\subsection{SCIENTIFIC MOTIVATION}

Large igneous provinces (LIPs) occur throughout Earth's history, at 20 - 30 myr intervals since $2.5 \mathrm{Ga}$, and at uncertain intervals in the Archean due to poorer preservation (e.g. Ernst, 2014 and references therein). A LIP as defined in Ernst (2014) is an event of widespread, predominantly mafic magmatism with a volume greater than $100,000 \mathrm{~km}^{3}$ and which covers an area of at least $100,000 \mathrm{~km}^{2}$. Furthermore, a LIP is characterized by a magmatic pulse of less than 1-5 Ma or a series of pulses extending over a maximum duration of approximately $50 \mathrm{Ma}$, and which is intraplate in terms of setting and or geochemical character (Ernst, 2014).

This thesis will focus on improving the understanding of the field, chemical, and temporal, tectonic and resource aspects of a poorly understood LIP event that affected Canada's Arctic margin as well as other parts of the circum-Arctic, manifested as the High Arctic Large Igneous Province, or HALIP, from the lens of volcanic and intrusive structures exposed in the South Fiord area of Axel Heiberg Island. The goals of this introductory chapter are threefold: (1) provide basic background into the geology, geography and magmatic history of the Arctic Margins, (2) introduce the geologic evolution of Canada's Arctic Islands with emphasis on its magmatic and volcanic history, and (3) detail the overall objectives this thesis with respect to the HALIP. 


\subsection{BATHYMETRY AND EVOLUTION OF THE ARCTIC BASIN}

The evolution of the Arctic margins through time and the underlying crustal composition of certain elements of its basins are scientifically contentious. The lack of easy access relative to other oceanic basins given the presence of sea-ice and isolation complicate geoscientific advancement in the Arctic. However as climate change gradually makes the Arctic more accessible, knowledge in the geology of the Arctic seafloor becomes increasingly important due to political undercurrents driven in part by Arctic nations' resource ambitions (e.g. Dodds, 2010). What is agreed upon is that, based on bathymetry (e.g. Jakobsson et al., 2012), the Arctic Ocean may be divided into two principal sub-basins: the Eurasian Basin and the Amerasian Basin, divided by the Lomonosov Ridge (Fig. 1.1). The Amerasian Basin itself is further divided into the Canada Basin on the one hand and the Makarov and Podvodnikov basins on the other, with the Alpha-Mendeleev Ridge separating the former from the latter two.

The tectonic evolution of the Amerasian Basin is thought to be mainly the result of rifting along a mid-ocean ridge that was perpendicular to the orientation of the AlphaMendeleev Ridge, with spreading occurring in a "windshield wiper” fashion about a rotational pole in the general vicinity of the Mackenzie River Delta of the Northwest Territories (Fig. 1.2; Lawver et al., 2002; Grantz and Hart, 2012; Shephard et al., 2013). The timing of this rifting event is somewhat controversial: Grantz et al. (2011) places the timing of basin-scale rifting in the Cretaceous while others, for example Shephard et al. (2013), model Arctic Basin rifting as taking place earlier in the Jurassic (prior to the onset of HALIP). What remains highly controversial is the composition of the crust underlying 
the Alpha Ridge: many consider it as being continental in origin (Petrov et al., 2016; Oakey and Saltus, 2016) while others favour the idea that the crust is slightly thickened oceanic crust (e.g. Forsyth et al., 1986; Jackson et al., 1986). Lastly, the most recent tectonic event to affect the Arctic Basin is ultra-slow sea-floor spreading in the Eurasian Basin along the Nansen-Gakkel Ridge that is an Arctic extension of the Mid-Atlantic Ridge. Using magnetic data along with seafloor spreading rate calculations, rifting in the Eurasian Basin appears to have commenced 58 Ma ago (Glebovsky et al., 2006).

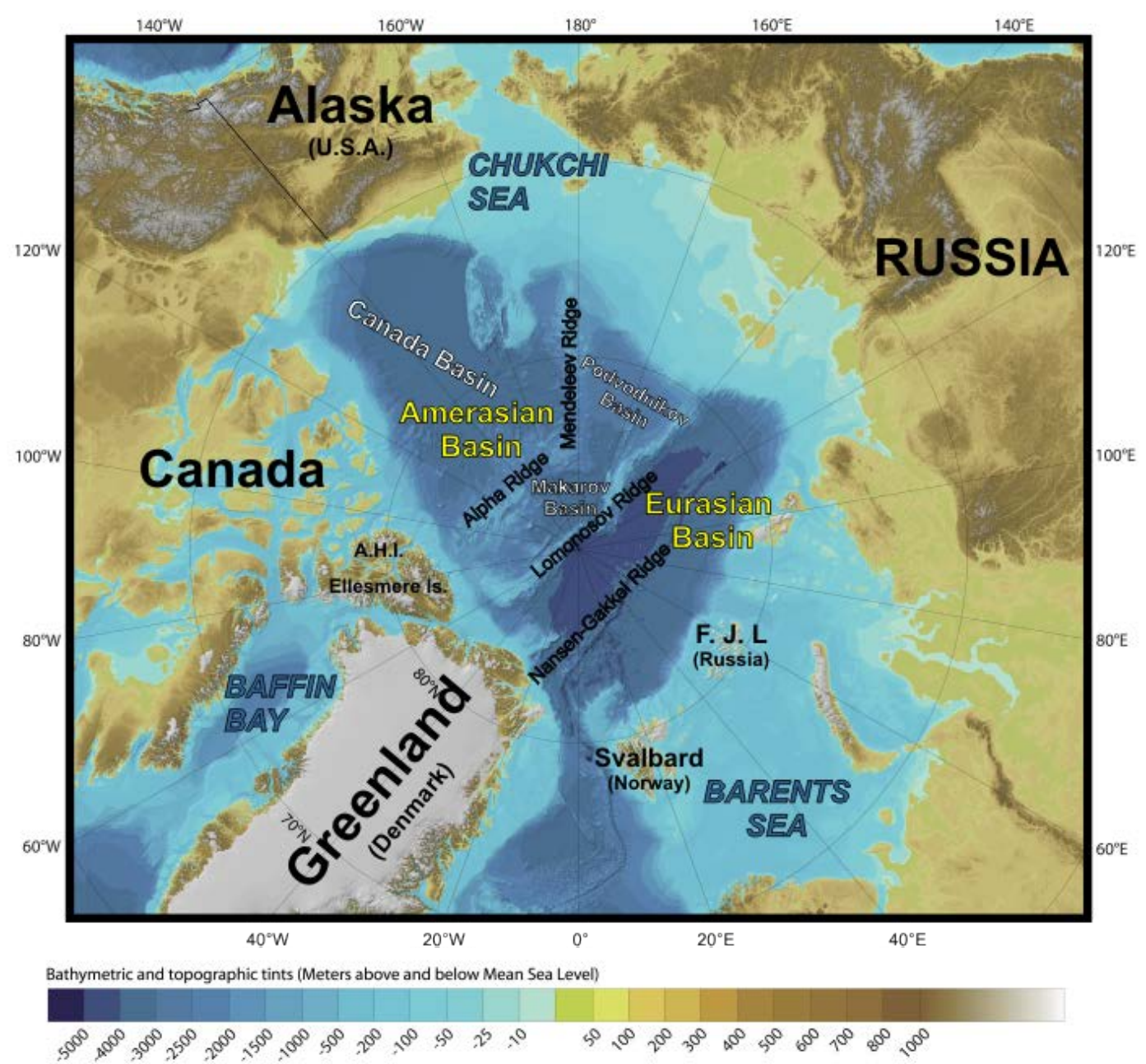

Figure 1.1: Bathymetry map of the Arctic Basin showing prominent bathymetric features and basins. Key to abbreviations: A.H.I. = Axel Heiberg Island; F.J.L. = Franz Josef Land. Modified from Jakobsson et al. (2012). 


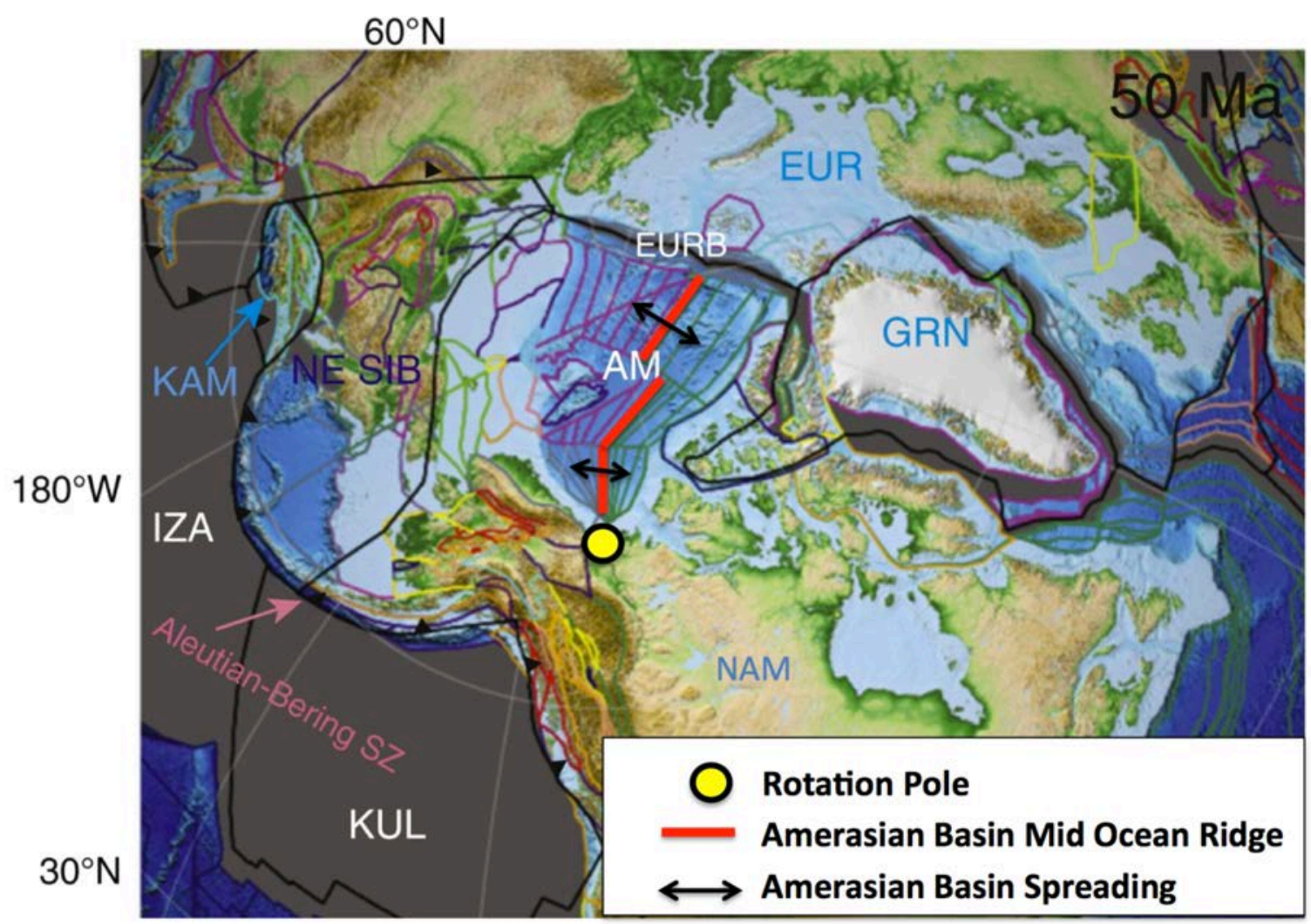

Figure 1.2: Tectonic Map of the Arctic Basin and adjacent regions in a reconstruction at $50 \mathrm{Ma}$ that highlights the rotational rifting of the Amerasian Basin (AM) about a pole in the Mackenzie River Delta. Note that at $50 \mathrm{Ma}$ the Eurasian Basin (EURB) is starting to open as a result of rifting associated with the Nanasen-Gakkel Ridge (Glebovsky et al., 2006). Both green and purple lines in Arctic Ocean represent mid-ocean ridge spreading trajectories on opposite sides of the mid-ocean ridge which is tied to different tectonic blocks. Key to other abbreviations in alphabetical order: EUR = Eurasian Plate, GRN = Greenland Plate, IZA = Izanagi Plate, KAM = Kamchatka Microplate KUL = Kula Plate, $\mathrm{NAM}=$ North American Plate, NE SIB $=$ NE Siberian Plate, $\mathrm{PAC}=$ Pacific Plate. Figure modified from Shephard et al. (2013). 


\subsection{SVERDRUP BASIN}

The geographic focus of this thesis, the South Fiord field area on Axel Heiberg Island, is located along the depositional axis of the elongate, SW-NE oriented, bananashaped Sverdrup Basin (Fig. 1.3). Measuring 1,300 km along axis and $480 \mathrm{~km}$ at its widest, this intracratonic basin, according to Embry and Beauchamp (2008), began to collect sediments in the Early Carboniferous and continued to evolve tectonically and sedimentologically through to the Paleocene when compressional tectonics, leading to the Eocene Eurekan Orogeny, ended sedimentation. The basin is approximately $13 \mathrm{~km}$ thick at its depositional axis. Based on detrital zircon geochronology as well as Sm-Nd isotopic systematics, sediments that constitute the Sverdrup Basin originated from Caledonian sources from what is now northern Greenland as well as the Franklinian mobile belt which lies unconformably below the Sverdrup Basin (Patchett et al., 2004; Røhr et al., 2010).

Initial quantitative subsidence modeling suggested a three phase evolutionary scenario for the Sverdrup Basin whereby high subsidence rates, possibly due to rifting at $330 \mathrm{Ma}, 225 \mathrm{Ma}$ and $124 \mathrm{Ma}$ (corresponding to Upper Mississippian, Upper Triassic and Lower Cretaceous, respectively; Cohen et al., 2013), exponentially grade into lower rates of subsidence (Sweeney, 1977). More recent modeling suggests that the basin experienced only two phases of rifting, signified by high subsidence rates, including initial basin development (Carboniferous - Permian) that was highly controlled by rifting (stretching factor $=\beta=\sim 2$ ) followed by passive subsidence throughout its subsequent development with the exception of a second phase of active extension $(\beta=1.3)$ from the Jurassic through to the Early Cretaceous (Stephenson et al., 1992). The existence of a 
Cretaceous rifting event within the Sverdrup Basin is not universally accepted, as

Sverdrup Basin rifting instead may have occurred in the Triassic as a precursory event leading to the eventual basin-scale rifting of the Amerasian Basin (Hadlari et al., 2016)

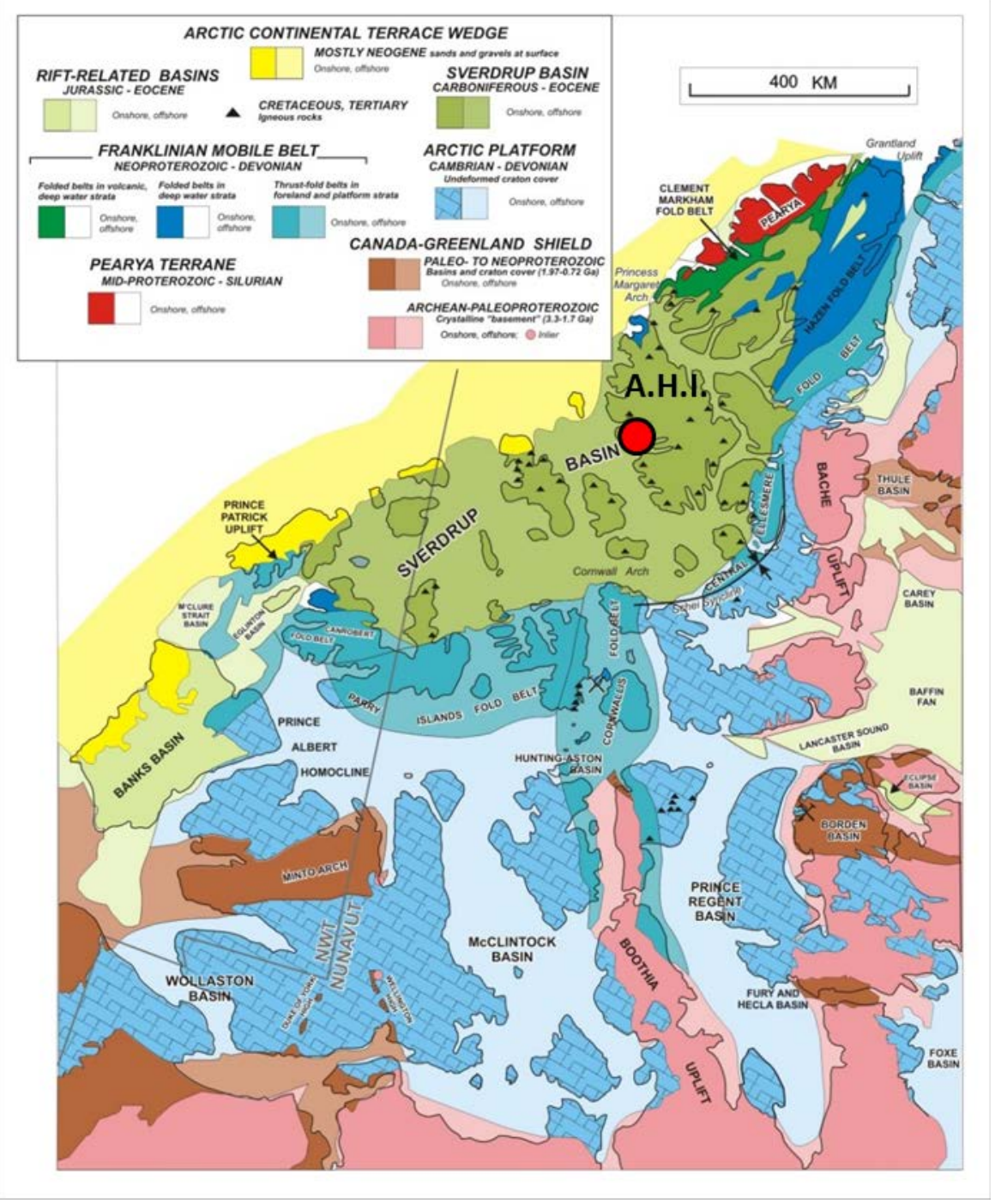

Figure 1.3: Regional geologic map of Canada's Queen Elizabeth Islands highlighting the extent of the Sverdrup Basin as well as the location of the South Fiord field area (red dot) on Axel Heiberg Island (A. H. I.). From Figure 2 of Percival et al. (2014). 


\subsection{HALIP PLUMBING SYSTEM AND GENESIS}

Sedimentary rocks which comprise the Sverdrup Basin are intruded by a gigantic swarm of Cretaceous mafic dykes belonging to the HALIP that are particularly concentrated on Axel Heiberg and Ellesmere islands but also include dykes in Svalbard (Norway) and Franz Josef Land (Russia) as shown in Figure 1.4 (Buchan and Ernst, 2006; Buchan and Ernst, 2013). A more detailed map of Canada's portion of the HALIP is shown in Figure 1.5. These dykes form a radiating pattern that converge to a point just north of Ellesmere Island where the offshore slope meets the southernmost extent of the Alpha Ridge (Fig. 1.4). In certain areas, such as Ellef Ringness Island and in the vicinity of Buchanan Lake (eastern Axel Heiberg Island), large HALIP mafic sills some of which are saucer shaped that measure up to $10 \mathrm{~km}$ in diameter have been mapped (Evenchick et al., 2015; Saumur et al., 2016). When they are tectonically restored to their pre-Gakkel Ridge configuration, exposed dykes and linear geophysical anomalies that are interpreted as dykes from Svalbard and Franz Josef Land extend the radiating pattern seen in Arctic Canada towards the Eurasian side of the Arctic (Buchan and Ernst, 2006; Døssing et al., 2013).

On Ellesmere Island's northern coast, the alkaline Wootton Igneous Complex ("Wootton Intrusion" more informally) is a heterogeneous sill-like intrusion which contains gabbroic and granitic phases (Estrada and Henjes-Kunst, 2013). This intrusion is shown on Figure 1.5. U-Pb age determinations from this intrusion show that emplacement occurred at $92 \mathrm{Ma}$ based on determinations from the gabbroic and microgranite phases (Trettin and Parrish, 1987; Estrada and Henjes-Kunst, 2013). Lastly, on the basis of aeromagnetic and gravity anomalies in the vicinity of Kleybolte Peninsula, 
extreme northwestern Ellesmere Island, another mafic intrusion has been geophysically identified and interpreted as a part of the HALIP (Blanchard, 2016).

The giant radiating pattern of mafic dykes (Figs. $1.4 \& 1.5)$ are magmatic evidence that the origin of the HALIP is a mantle plume head that was centred at the Ellesmere Island slope-Alpha Ridge nexus (Ernst and Buchan, 2003; Buchan and Ernst, 2006). Furthermore, erosional unconformities in Svalbard (Norway) along with southward prograding clinoforms in the Barents Sea provide sedimentary evidence of domal uplift associated with mantle plume activity in the direction towards the Alpha Ridge (Maher, 2001; Polteau et al., 2016). 


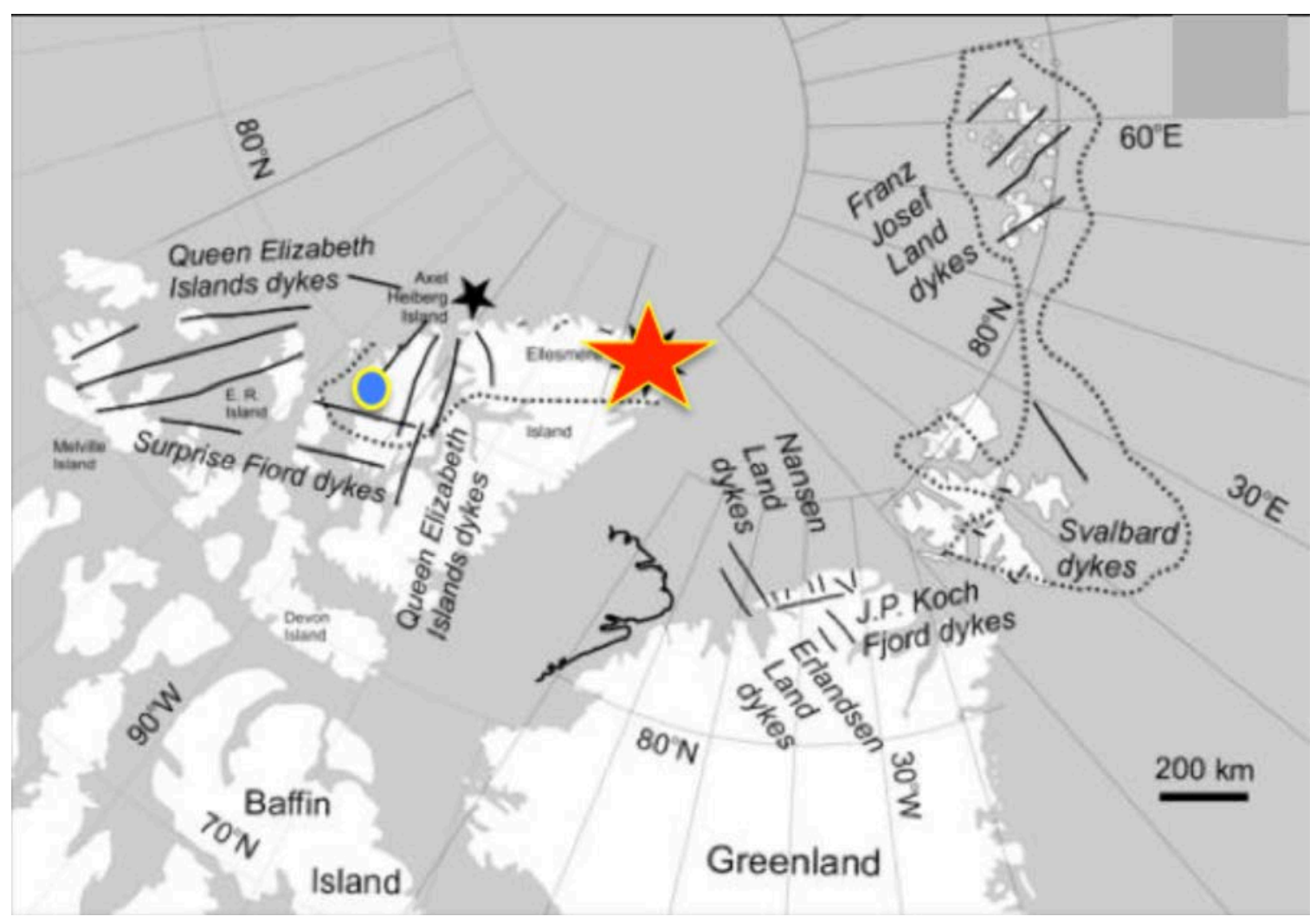

Figure 1.4: Map showing simplified distribution and orientation of major dyke swarms that are the plumbing system of HALIP based on the tectonic configuration at the time of Cretaceous HALIP magmatism. Black star denotes convergence of Queen Elizabeth Island swarm (Buchan and Ernst, 2006). Red star denotes the mantle plume head identified from the radiating dyke swarm pattern after correction for the deformation (mainly westward directed thrusting) associated with the subsequent Eurekean orogeny. Black coastal outline northwest of Greenland represent present-day relative position of Ellesmere Island with respect to Greenland. From Figure 2b in Buchan and Ernst (2006). Location of South Fiord field area, the focus of this thesis, is shown by a blue circle. 


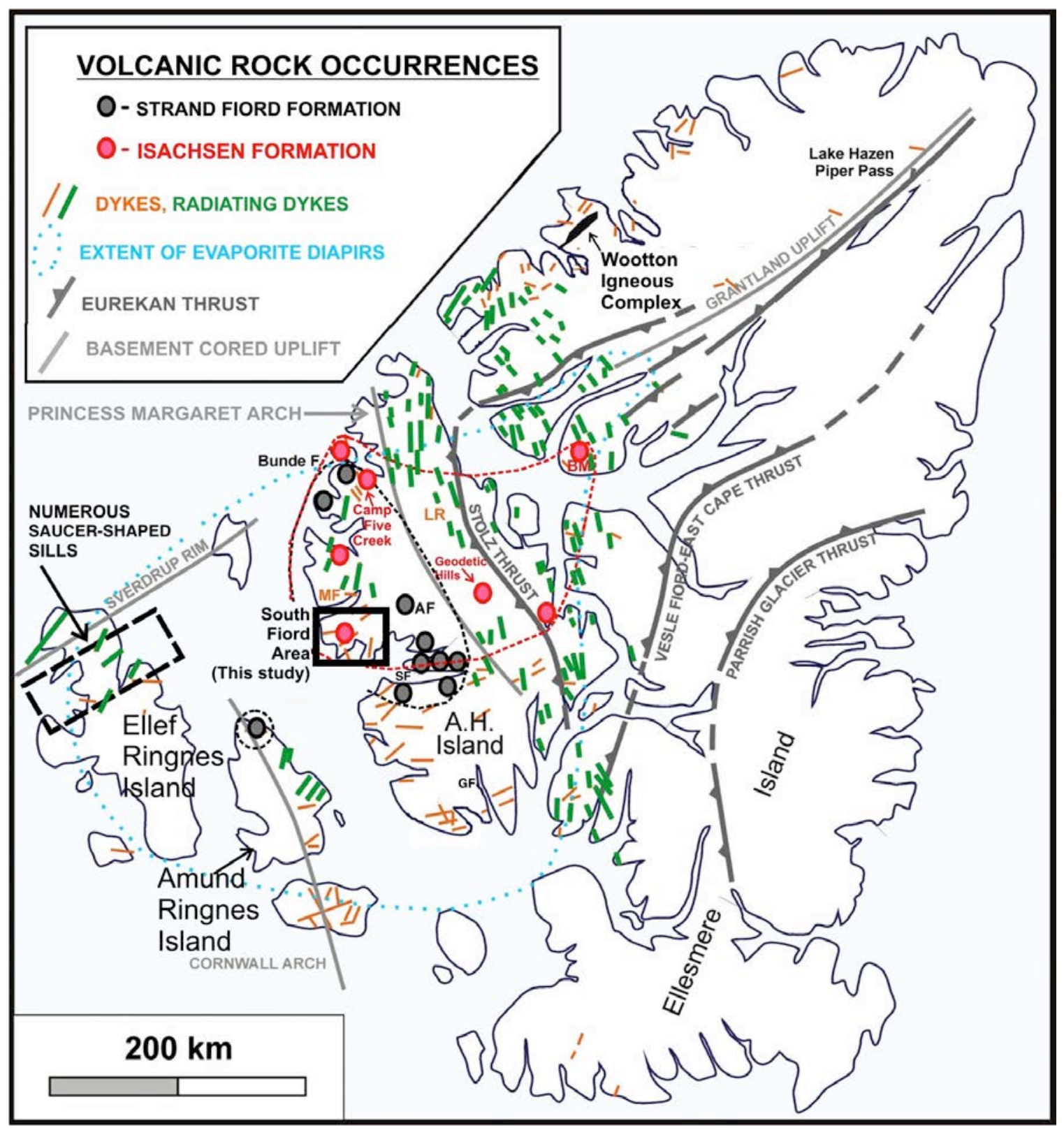

Figure 1.5: Map of Canada's Queen Elizabeth Islands showing the distribution and trends of mafic dykes as well as the geographic distribution (short-dashed lines) and localities (dots) of mafic lavas in the 120 - 130 Ma Isachsen Formation and c. 95 - 100 Ma Strand Fiord Formation basalts. Short-dashed distribution of lavas from Estrada and Henjes-Kunst (2004). Distribution of evaporites from Nassichuk and Davies (1980). Saucer-shaped sill area on Ellef Ringnes Island from Evenchick et al. (2015). Figure modified from Saumur et al. (2016). Key to abbreviations: A. H. = Axel Heiberg; BM = Blue Mountain; LR - Lightfoot River; MF = Middle Fiord; SF = Strand Fiord; GF = Glacier Fiord. 


\subsection{THE ISACHSEN FORMATION}

The Isachsen Formation is a Lower Cretaceous (c. 120 - 130 Ma) lithologic unit that is composed of predominantly sandstones and shales but contains mafic lavas of variable stratigraphic abundance (Embry and Osadetz, 1988). Chemically, the lavas that erupted within the Isachsen Formation are subalkaline tholeiitic basalts (Estrada and Henjes-Kunst, 2004; Jowitt et al., 2014), and characterizing the petrogenetic processes that governed the evolution of the Isachsen Formation basalts is a research goal of this thesis. Stratigraphically, the Isachsen Formation is separated into three members: the basal, sandstone-dominated Paterson Island member, the central shale-rich Rondon Member, and the upper predominantly sandstone-bearing Walker Island member (Embry and Osadetz, 1988; Tullius et al., 2014). Volcanic flows occur in both the Paterson Island and Walker Island members. A stratigraphic profile of the Sverdrup Basin is provided in Chapter 3 (Fig. 3.3) that shows the stratigraphic relations of the Sverdrup Basin (including the Isachsen Formation; Embry and Osadetz, 1988). The depositional environment varies considerably within the Isachsen Formation, with the shale-dominant Rondon member interpreted as marine while the quartz-sandstone-dominated Paterson and Walker Island members record marginal marine, floodplain and meandering stream environments (Tullius et al., 2014). The quartz-rich sandstone has been interpreted as evidence of sediment derived from recycled orogens (e.g. Franklinian mobile belt) and cratonic sources (Tullius et al., 2014). This conclusion is consistent with isotopic and geochemical provenance studies by Patchett et al. (2004) who consider that contributions from the Franklinian mobile belt dominated contributions to the Isachsen Formation. The sedimentation associated with the Isachsen Formation corresponds to the time in which 
the second phase of rifting of the Sverdrup Basin is proposed to have begun (Embry and Beauchamp (2008), see previous section). However under the model favoured by Hadlari et al. (2016), the Isachsen Formation was deposited during passive subsidence of the basin.

\subsection{THE STRAND FIORD FORMATION}

Unlike much of the lithology of the Sverdrup Basin, the Strand Fiord Formation is not sedimentary, but rather a sequence of laterally extensive basaltic lavas which are exposed predominantly on Axel Heiberg Island. The Strand Fiord Formation lavas are compositionally classified as subalkaline tholeiitic basalts and were erupted c. $95-100$ Ma based on chronostratigraphy and Ar-Ar age dating (Estrada and Henjes-Kunst, 2004; Jowitt et al., 2014; Villeneuve and Williamson, 2006; Embry and Osadetz, 1988). Furthermore, this continental flood basalt package features individual flows which range from $6-60 \mathrm{~m}$ in thickness. The Strand Fiord Formation as a whole is thickest on the northwestern coast of Axel Heiberg Island, approaching $800 \mathrm{~m}$ in the vicinity of Bunde Fiord (Fig. 1.5), and thins to zero on the Island's southern coast (Ricketts et al., 1985). The variation in present-day thickness of the Strand Fiord Formation lavas, is controlled by the number of flows as well as erosion. Recent work revealed a $950 \mathrm{~m}$ succession of lavas $\sim 25 \mathrm{~km}$ NE of South Fiord in the general vicinity of Agate Fiord that is abbreviated "AF" in Figure 1.5 (Williamson et al., 2016). It is interesting to note, that contrary to much of the Sverdrup Basin where deposition of each unit is generally symmetric about the depositional axis (Embry and Beauchamp, 2008), the Strand Fiord Formation is among its thickest along the Sverdrup Basin's northern margin in the vicinity of Bunde 
Fiord (Ricketts et al., 1985). The Strand Fiord Formation caps a succession of stratigraphic units associated with Aptian - early Cenomanian transgressive-regressive cycles. Geochemical characterization and fingerprinting of intrusions associated with these lavas are detailed in Chapter 3 and the geochronology of the Strand Fiord lavas is detailed more fully in Chapter 4 of this thesis.

\subsection{EVAPORITE GEOLOGY}

The Sverdrup Basin plays host to many mapped hydrocarbon reservoirs, and for much of these, the principal traps are a network of evaporite diapirs and salt canopies intruded into shallower strata from the Carboniferous Otto Fiord Formation (Embry, 2011; Nassichuk and Davies, 1980; Jackson and Harrison, 2006). The general distribution of these evaporite domes can be seen in Figure 1.5. In one estimation, Axel Heiberg Island contains the second highest concentration of evaporite diapirs in the world, superseded only by Iran (Jackson and Harrison, 2006).

The lithology of the Otto Fiord Formation is heterogeneous, ranging from major units of limestone and evaporite (predominantly anhydrite), with local concentrations of halite in the cores of a couple of domes, in addition to minor sandstone and shale (Nassichuk and Davies, 1980). The thickness of the in-situ, non-diapiric portions of the Otto Fiord Formation varies, with a maximum thickness of $420 \mathrm{~m}$ in northern Ellesmere Island along the depositional axis of the Sverdrup Basin and pinches out towards eastern Axel Heiberg Island distal to the Sverdrup Basin axis (Nassichuk and Davies, 1980). 


\subsection{THESIS SCOPE}

\subsubsection{Field geology}

Apart from detailed field work on Ellef Ringnes Island along with certain locations on Axel Heiberg Island, the distribution of intrusive structures have only been dealt with at the reconnaissance level (Evenchick et al., 2015; Saumur et al., 2016; Williamson et al., 2016). This thesis examines mafic igneous units within the South Fiord region of Axel Heiberg Island (both basaltic lavas and mafic intrusions) which exist as a component of the broader HALIP. Until the 2013 field season (outlined in Chapter 2), the South Fiord region of Axel Heiberg Island was poorly understood in terms of a detailed geologic field assessment. The South Fiord field area was initially selected for its exposures of mafic dykes and sills that intrude the Isachsen Formation, with the idea that this thesis would primarily deal with the volcanic rocks within the Isachsen Formation and their presumed intrusive equivalents. Detailed mapping using field and remote sensing techniques discussed in Chapter 2, provides a firm foundation into the field geology of the South Fiord area and provides context for the chemical and temporal aspects of this HALIP research presented in Chapters 3 and 4, respectively.

\subsubsection{Geochemistry}

Geochemically, the HALIP contains two broad geochemical groupings, a subalkaline group and an alkaline group (Jowitt et al., 2014). Geochemical analyses on samples taken from 121-126 Ma saucer-shaped sills on Ellef Ringnes Island as well as dykes on Ellesmere Island reveal consistent subalkaline basaltic compositions (Evenchick et al., 2015; Hachkowski, 2011). However, the ca. 92 Ma Wootton Igneous Complex 
along with the Hansen Point Volcanics are alkaline. Geochemical studies on the older (ca. 120-130 Ma) Isachsen Formation and younger (ca. 95-100 Ma) Strand Fiord Formation lavas reveal that both are composed of subalkaline basalts (Estrada and Henjes-Kunst, 2004), but that the 90 - 100 Ma Hassel Formation lavas are alkaline (Estrada, 2014). A gap in knowledge this thesis seeks to fill is to determine if there are any diagnostic trace element or isotopic ratios that can be used to distinguish the two main subalkaline groups: the older (ca. 120-130 Ma) Isachsen Formation lavas and the younger (ca. 95-100 Ma) Strand Fiord Formation lavas and what specific processes led to these chemical compositions.

\subsubsection{Geochronology}

Certain aspects relating to the evolution of the HALIP remains poorly constrained. The current geochronology of the HALIP is based mostly on Ar-Ar and stratigraphy as well as some U-Pb dating (see detailed summary in Chapter 4). The stratigraphy of the Sverdrup Basin indicates four cycles of volcanic activity (Embry and Osadetz, 1988). U$\mathrm{Pb}$ and $\mathrm{Ar}-\mathrm{Ar}$ geochronology data suggest three pulses of magmatism: two pulses of subalkaline magmatism occur at ca. 120-130 Ma and ca. 95-100 Ma, corresponding with the two cycles of Isachsen Formation volcanism (ca. 120 - $130 \mathrm{Ma}$ ) and one cycle of Strand Fiord Formation lavas (Fig. 1.6). A third, younger pulse at ca. 80 Ma corresponds to the fourth cycle and is manifested as the Hansen Point Volcanics (Estrada and HenjesKunst, 2013). The intrusions from South Fiord are considered part of the HALIP plumbing system, but prior to this study it was unknown whether they fed $120-130 \mathrm{Ma}$ Isachsen or c. 95 - 100 Ma Strand Fiord Formation flood lavas and therefore represent a 
gap in knowledge. U-Pb ages from intrusions in Franz Josef Land and Svalbard (Corfu et al., 2013) indicate ages of $121 \mathrm{Ma}-124 \mathrm{Ma}$, while the U-Pb ages from the Canadian portion include sills on Ellef Ringnes Island dated at $121 \mathrm{Ma}$ and $126 \mathrm{Ma}$ (Evenchick et al. 2015) and the Wootton Igneous Complex dated at $92 \mathrm{Ma}$ (Estrada and Henjes-Kunst, 2013; Trettin and Parrish, 1987). Despite the growing number of U-Pb age determinations on intrusive rocks, principally associated with the c. $120 \mathrm{Ma}-130 \mathrm{Ma}$ pulse of the HALIP, there is a need to better constrain the timing of the volcanic and intrusive sequences associated with the ca. 95 - 100 Ma Strand Fiord Formation lavas using U-Pb geochronology.

Figure 1.6 (next page): U-Pb age spectrum "barcode" of dated mafic intrusions ascribed to HALIP. Thin horizontal lines represent individual reported ages with grey vertical rectangles representing $2 \sigma$ uncertainties. Lower-case " $b$ " represents age determinations from baddeleyite, lower-case " $t$ " represent age of titanite, determinations without lowercase letters are from zircon. Orange rectangles in the Canada/Greenland column represent the four volcanic cycles of Embry and Osadetz (1988). Question marks to the left of Cycle 3, indicate a gap in U-Pb age data prior to this study . Key to abbreviations: PIM, IF = Paterson Island Member of Isachsen Formation; WIM, IF = Walker Island Member of Isachsen Formation; SFF = Strand Fiord Formation; HPV = Hansen Point Volcanics; W.I.C. $=$ Wootton Igneous Complex; EI= Ellesmere Island; AHI = Axel Heiberg Island, EHI $=$ Ellef Ringnes Island; Svbd $=$ Svalbard (Norway); FJL $=$ Franz Josef Land (Russia). Key to data sources: $1=$ Thórarinsson et al. (2015); $2=$ Trettin and Parrish (1987); 3 = Estrada and Henjes-Kunst (2013); 4 = Evenchick et al. (2015); 5 = Corfu et al. (2013). 


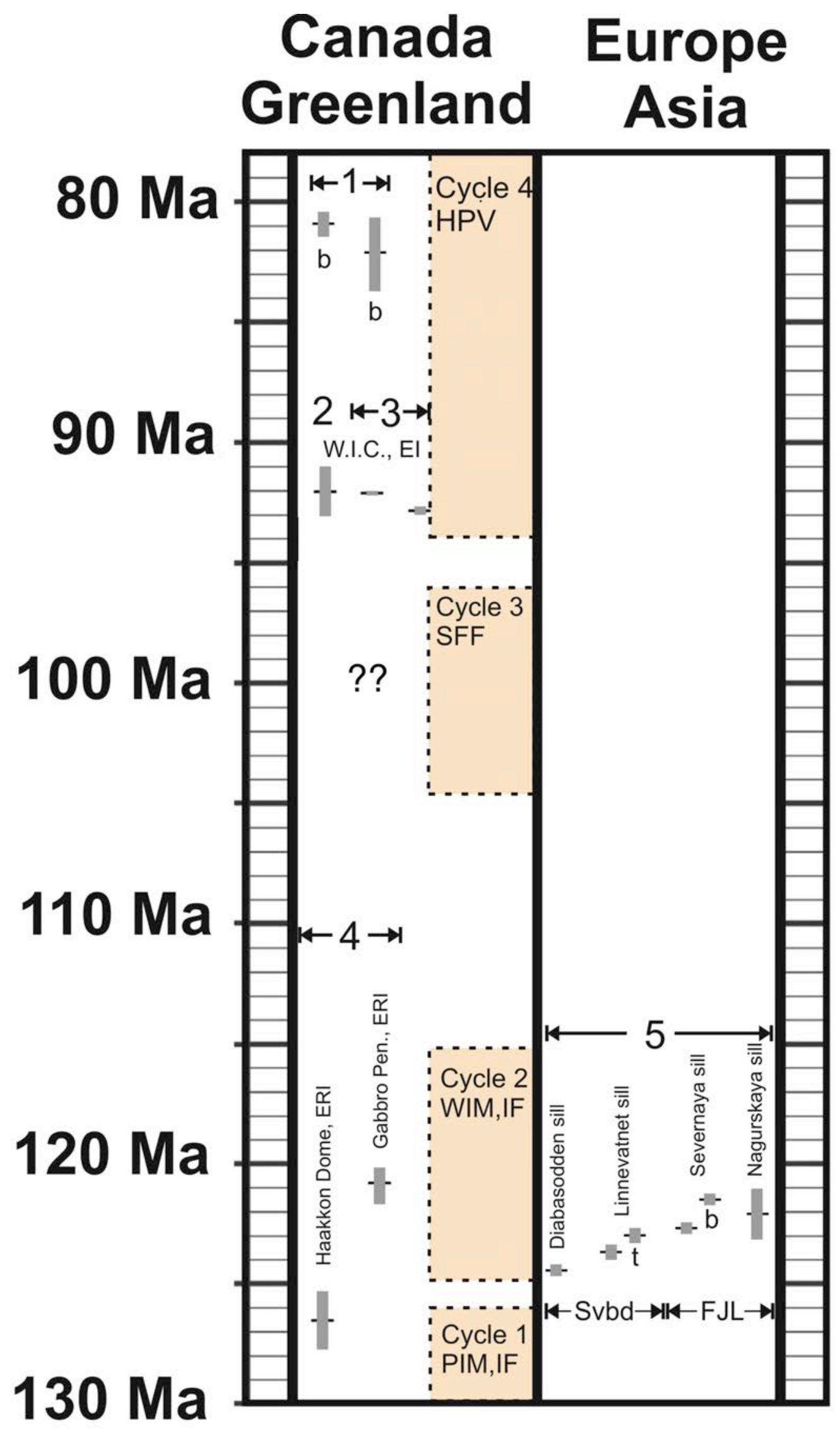




\subsubsection{Thesis objectives and structure}

The objectives of this thesis are threefold:

1. Characterize the geologic relationships between mafic intrusions, lava flows and host sedimentary rocks in the South Fiord field area using remote sensing and field techniques (Chapter 2)

2. Characterize the petrogenetic evolution of mafic magmatism (dykes, sills and volcanic rocks) within South Fiord area, based on major, trace and isotopic study of samples collected in 2013 and compare with reference suites of Isachsen Formation lavas collected at Camp Five Creek and Geodetic Hills (Williamson, pers. commun, 2014; Williamson, 1988) and Strand Fiord Formation flood basalts (based on Jowitt et al. 2014).

3. Constrain the timing of magmatism in the South Fiord field area through high precision U-Pb geochronology and use these dates to (1) link their emplacement time with known magmatic pulses i.e. the Strand Fiord Formation, and (2) speculate on the geometry of the Strand Fiord Formation plumbing system (Chapter 4).

Chapter 2 presents the results of fieldwork and remote sensing mapping in the South Fiord region of Axel Heiberg Island. Newly recognized tabular diabasic intrusions (dykes and sills), in addition to those previously known were characterized in terms of trend, dip and thickness. Furthermore, samples from the South Fiord field area were collected for geochemistry and isotopic study from both South Fiord intrusions and Isachsen Formation lava flows in the area. Chapter 3 provides a geochemical characterization of 
both the Isachsen flows and the South Fiord intrusions and these data are compared with data from Strand Fiord lavas exposed outside of the study area. Chapter 4 presents two new U-Pb ages on South Fiord intrusions which therefore provide the first precise age constraint on the Strand Fiord Formation.

\subsection{THEMATIC INTEGRATION OF CHAPTERS OF THIS THESIS}

This thesis provides a geologic assessment into the occurrence of mafic igneous rocks within South Fiord that exist as a portion of the broader HALIP. In Chapter 2, field and satellite data around the South Fiord region of Axel Heiberg Island were used to map the distribution of igneous intrusions as well as lava flows within the Isachsen Formation both within the South Fiord area and in its periphery in order to provide a field inventory into the types of igneous structures that are present in the South Fiord Field area, and a geological context for the geochemistry and geochronology data of Chapters 3 and 4 . A sample suite collected from intrusions and flows from the South Fiord area were analyzed geochemically and isotopically in order to assess mantle source(s) and sources of crustal contamination as well as comparing these with the geochemistry of the two subalkaline magmatic pulses of HALIP (Isachsen and Strand Fiord). U-Pb age dating on South Fiord intrusions in Chapter 4 completes this geologic assessment by identifying which of the two subalkaline magmatic pulses these intrusions fed and providing constraints on the timing of the HALIP. 


\subsection{CHAPTER REFERENCES}

Blanchard, J., 2016, Geophysical Identification and Characterization of Mafic-Ultramafic Intrusions in Plume Centre Regions: M.Sc. thesis, Carleton University, Ottawa, Ontario, 217 p.

Buchan, K.L., and Ernst, R.E., 2013, Diabase dyke swarms of Nunavut, Northwest Territories and Yukon, Canada: Geological Survey of Canada Open File 7464, 2013; 24 pages ( 1 sheet).

Buchan, K.L., and Ernst, R.E., 2006, Giant dyke swarms and the reconstruction of the Canadian Arctic islands , Greenland , Svalbard and Franz Josef Land, in Hanski, E., Mertanen, S., Ramo, T., and Vuollo, J. eds., Dyke Swarms - Time Markers of Crustal Evolution, Taylor \& Francis, p. 27-48.

Cohen, K.M., Finney, S.C., Gibbard, P.L., and Fan, J.-X., 2013, The ICS International Chronostratigraphic Chart: Episodes, v. 36, p. 199-204, doi: 10.1111/j.15023931.1980.tb01026.x.

Corfu, F., Polteau, S., Planke, S., Faleide, J.I., Svensen, H., Zayoncheck, A., and Stolbov, N., 2013, U-Pb geochronology of Cretaceous magmatism on Svalbard and Franz Josef Land, Barents Sea Large Igneous Province: Geological Magazine, v. 150, no. 6,p. 1127-1135, doi: 10.1017/S0016756813000162.

Dodds, K., 2010, Flag planting and finger pointing: The Law of the Sea, the Arctic and the political geographies of the outer continental shelf: Political Geography, v. 29, no. 2 , p. 63-73, doi: 10.1016/j.polgeo.2010.02.004.

Døssing, A., Jackson, H.R., Matzka, J., Einarsson, I., Rasmussen, T.M., Olesen, A. V, 
and Brozena, J.M., 2013, On the origin of the Amerasia Basin and the High Arctic Large Igneous Province -- Results of new aeromagnetic data: Earth and Planetary Science Letters, v. 363, p. 219-230.

Embry, A.F., 2011, Chapter 36 Petroleum prospectivity of the Triassic-Jurassic succession of Sverdrup Basin, Canadian Arctic Archipelago: Geological Society, London, Memoirs, v. 35, no. 1, p. 545-558, doi: 10.1144/M35.36.

Embry, A.F., and Beauchamp, B., 2008, Chapter 13: Sverdrup Basin, in Miall, A.D. ed., Sedimentary Basins of the World: Volume 5, p. 451-471.

Embry, A.F., and Osadetz, K.G., 1988, Stratigraphy and tectonic significance of Cretaceous volcanism in the Queen Elizabeth Islands, Canadian Arctic Archipelago: Canadian Journal of Earth Sciences, v. 25, p. 1209-1219.

Ernst, R.E., 2014, Large Igneous Provinces: Cambridge University Press, Cambridge, $\mathrm{UK}, 653 \mathrm{p}$.

Ernst, R.E., and Buchan, K.L., 2003, Recognizing mantle plumes in the geological record: Annual Review of Earth and Planetary Sciences, v. 31, no. 1, p. 469-523, doi: 10.1146/annurev.earth.31.100901.145500.

Estrada, S., 2014, Geochemical and $\mathrm{Sr}-\mathrm{Nd}$ isotope variations within Cretaceous continental flood-basalt suites of the Canadian High Arctic, with a focus on the Hassel Formation basalts of northeast Ellesmere Island: International Journal of Earth Sciences, v. 104, p. 1981-2005, doi: 10.1007/s00531-014-1066-x.

Estrada, S., and Henjes-Kunst, F., 2013, 40Ar-39Ar and U-Pb dating of Cretaceous continental rift-related magmatism on the northeast Canadian Arctic margin: 
Zeitschrift der Deutschen Gesellschaft für Geowissenschaften, v. 164, no. 1, p. 107130, doi: 10.1127/1860-1804/2013/0005.

Estrada, S., and Henjes-Kunst, F., 2004, Volcanism in the Canadian High Arctic related to the opening of the Arctic Ocrean: Z. dt. geol. Ges, v. 154, no. 4, p. 579-603.

Evenchick, C.A., Davis, W.J., Bédard, J.H., Hayward, N., and Friedman, R.M., 2015, Evidence for protracted High Arctic large igneous province magmatism in the central Sverdrup Basin from stratigraphy, geochronology, and paleodepths of saucer-shaped sills: Geological Society of America Bulletin, p. 1 - 25, doi: 10.1130/B31190.1.

Forsyth, D.A., Asudeh, I., Green, A.G., and Jackson, H.R., 1986, Crustal structure of the northern Alpha Ridge beneath the Arctic Ocean: Nature, v. 322, no. 6077, p. 349352, doi: $10.1038 / 322349 \mathrm{a} 0$.

Glebovsky, V.Y., Kaminsky, V.D., Minakov, A. N., Merkur'ev, S. A., Childers, V. A., and Brozena, J.M., 2006, Formation of the Eurasia Basin in the Arctic Ocean as inferred from geohistorical analysis of the anomalous magnetic field: Geotectonics, v. 40, no. 4, p. 263-281, doi: 10.1134/S0016852106040029.

Grantz, A., and Hart, P.E., 2012, Petroleum prospectivity of the Canada Basin, Arctic Ocean: Marine and Petroleum Geology, v. 30, no. 1, p. 126-143, doi: 10.1016/j.marpetgeo.2011.11.001.

Grantz, A., Hart, P.E., and Childers, V. A., 2011, Chapter 50 Geology and tectonic development of the Amerasia and Canada Basins, Arctic Ocean: Geological Society, London, Memoirs, v. 35, no. 1, p. 771-799, doi: 10.1144/M35.50. 
Hachkowski, C., 2011, Geochemistry and isotopic analysis of mafic dykes from the Raanes Peninsula, Ellesmere Island, Nunavut, Canada: B.Sc thesis, Carleton University, Ottawa, Ontario, $101 \mathrm{p}$.

Hadlari, T., Midwinter, D., Galloway, J.M., Dewing, K., and Durbano, A.M., 2016, Mesozoic rift to post-rift tectonostratigraphy of the Sverdrup Basin, Canadian Arctic: Marine and Petroleum Geology, v. 76, p. 148-158, doi:

10.1016/j.marpetgeo.2016.05.008.

Jackson, H.R., Forsyth, D.A., and Johnson, G.L., 1986, Oceanic afinities of the Alpha Ridge, Arctic Ocean: Marine Geology, v. 73, p. 237-261.

Jackson, M.P.A., and Harrison, J.C., 2006, An allochthonous salt canopy on Axel Heiberg Island, Sverdrup Basin, Arctic Canada: Geology, v. 34, no. 12, p. 10451048.

Jackson, M.P., and Harrison, J.C., 2010, Geology, Strand Fiord-Expedition Fiord Area, Western Axel Heiberg Island, Nunavut.: Geological Survey of Canada, Map 2157A, scale 1:100,000.

Jakobsson, M., Mayer, L., Coakley, B., Dowdeswell, J.A., Forbes, S., Fridman, B., Hodnesdal, H., Noormets, R., Pedersen, R., Rebesco, M., Schenke, H.W., Zarayskaya, Y., Accettella, D., Armstrong, A., et al., 2012, The International Bathymetric Chart of the Arctic Ocean (IBCAO) Version 3.0: Geophysical Research Letters, v. 39, no. 12, p. 1-6, doi: 10.1029/2012GL052219.

Jowitt, S.M., Williamson, M., and Ernst, R.E., 2014, Geochemistry of the 130 to $80 \mathrm{Ma}$ Canadian High Arctic Large Igneous Province (HALIP) Event and Implications for 
Ni-Cu-PGE Prospectivity: Economic Geology, v. 109, no. 2, p. 281-307.

Lawver, L.A., Grantz, A., and Gahagan, L.M., 2002, Plate kinematic evolution of the present Arctic region since the Ordovician: Geological Society of America Special Papers, v. 360, p. 333-358, doi: 10.1130/0-8137-2360-4.333.

Maher, H.D., 2001, Manifestations of the Cretaceous High Arctic Large Igneous Province in Svalbard: The Journal of Geology, v. 109, no. 1, p. 91-104, doi: $10.1086 / 317960$.

Nassichuk, W.W., and Davies, G.R., 1980, Stratigraphy and sedimentation of the Otto Fiord formation - a major Mississippian-Pennsylvanian evaporite of subaqueous origin in the Canadian Arctic Archipelago, in Irish, E.J.W. ed., Geological Survey of Canada Bulletin 286, Ottawa, ON, p. 87.

Oakey, G.N., and Saltus, R.W., 2016, Geophysical analysis of the Alpha-Mendeleev ridge complex: Characterization of the High Arctic Large Igneous Province: Tectonophysics, doi: 10.1016/j.tecto.2016.08.005.

Patchett, P.J., Embry, A.F., Ross, G.M., Beauchamp, B., Harrison, J.C., Mayr, U., Isachsen, C.E., Rosenberg, E.J., and Spence, G.O., 2004, Sedimentary Cover of the Canadian Shield through Mesozoic Time Reflected by Nd Isotopic and Geochemical Results for the Sverdrup Basin, Arctic Canada: The Journal of Geology, v. 112, no. 1, p. 39-57.

Percival, J.B., Williamson, M.-C., McNeil, R.J., Day, S.J.A., and Harris, J.R., 2014, Morphology of gossans in the Canadian Arctic Islands, in Williamson, M.-C. ed., Environmental and Economic Significance of Gossans, Geological Survey of 
Canada Open File 7718, p. 58-73.

Petrov, O., Morozov, A., Shokalsky, S., Kashubin, S., Artemieva, I.M., Sobolev, N., Petrov, E., Ernst, R.E., Sergeev, S., and Smelror, M., 2016, Crustal structure and tectonic model of the Arctic region: Earth-Science Reviews, v. 154, p. 29-71, doi: 10.1016/j.earscirev.2015.11.013.

Polteau, S., Hendriks, B.W.H., Planke, S., Ganerød, M., Corfu, F., Faleide, J.I., Midtkandal, I., Svensen, H.S., and Myklebust, R., 2016, The Early Cretaceous Barents Sea Sill Complex: Distribution, 40Ar/39Ar geochronology, and implications for carbon gas formation: Palaeogeography, Palaeoclimatology, Palaeoecology, v. 441, p. 83-95, doi: 10.1016/j.palaeo.2015.07.007.

Ricketts, B., Osadetz, K.G., and Embry, A.F., 1985, Volcanic style in the Strand Fiord Formation (Upper Cretaceous), Axel Heiberg Island, Canadian Arctic Archipelago: Polar Research, v. 3, no. 1, p. 107-122, doi: 10.1111/j.1751-8369.1985.tb00497.x.

Røhr, T.S., Andersen, T., Dypvik, H., and Embry, A.F., 2010, Detrital zircon characteristics of the Lower Cretaceous Isachsen Formation, Sverdrup Basin: source constraints from age and Hf isotope data: Canadian Journal of Earth Sciences, v. 47, p. 255-271, doi: 10.1139/E10-006.

Saumur, B.-M., Dewing, K., and Williamson, M.-C., 2016, Architecture of the Canadian portion of the High Arctic Large Igneous Province and implications for magmatic $\mathrm{Ni}-\mathrm{Cu}$ potential: Canadian Journal of Earth Sciences, v. 53, p. 528-542.

Shephard, G.E., Müller, R.D., and Seton, M., 2013, The tectonic evolution of the Arctic since Pangea breakup: Integrating constraints from surface geology and geophysics 
with mantle structure: Earth-Science Reviews, v. 124, p. 148-183, doi:

10.1016/j.earscirev.2013.05.012.

Stephenson, R.A., Boerstoel, J., Embry, A.F., and Ricketts, B.D., 1992, Subsidence analysis and tectonic modelng of the Sverdrup Basin, in ICAM Proceedings, p. 149154.

Sweeney, J.F., 1977, Geological Society of America Bulletin Subsidence of the Sverdrup Basin , Canadian Arctic Islands Subsidence of the Sverdrup Basin , Canadian Arctic Islands: Geological Society of America Bulletin, v. 88, no. 88, p. 41-48, doi: 10.1130/0016-7606(1977)88<41.

Thorsteinsson, R., and Tozer, E.T., 1971, Geology, Middle Fiord, District of Franklin: Geological Survey of Canada, Map 1299A, scale 1:250,000.

Trettin, H.P., and Parrish, R., 1987, Late Cretaceous bimodal magmatism, northern Ellesmere Island: isotopic age and origin: Canadian Journal of Earth Sciences, v. 24, p. 257-265.

Tullius, D.N., Leier, A.L., Galloway, J.M., Embry, A.F., and Pedersen, P.K., 2014, Sedimentology and stratigraphy of the Lower Cretaceous Isachsen Formation: Ellef Ringnes Island, Sverdrup Basin, Canadian Arctic Archipelago: Marine and Petroleum Geology, v. 57, p. 135-151, doi: 10.1016/j.marpetgeo.2014.05.018.

Villeneuve, M., and Williamson, M.-C., 2006, 40Ar-39Ar dating of mafic magmatism from the Sverdrup Basin Magmatic Province, in Scott, R.A. and Thurston, D.K. eds., Proceedings of the Fourth International Conference on Arctic Margins, p. 206215. 
Williamson, M.-C., 1988, The Cretaceous igneous province of the Sverdrup Basin, Canadian Arctic: Field relations and petrochemical studies: Ph.D. thesis, Dalhousie University, Halifax, Nova Scotia, 417 p.

Williamson, M.-C., Saumur, B.-M., and Evenchick, C.A., 2016, HALIP volcanicintrusive complexes, Axel Heiberg Island, Nunavut in Williamson, M.-C., Ed.: Report of Activities for High Arctic Large Igneous Province (HALIP)-GEM 2 Western Arctic Region Project: Bedrock Mapping and Mineral Exploration: Geological Survey of Canada Open File 7950, p. 14-26, doi: 10.4095/297487. 


\section{Chapter 2:}

\section{Field mapping and remote sensing of mafic igneous structures in the South Fiord locality, Axel Heiberg Island, Nunavut.}

\subsection{INTRODUCTION}

The geology of Queen Elizabeth Islands in Canada's High Arctic is dominated by the Carboniferous - Eocene Sverdrup Basin and the underlying Neoproterozoic Devonian Franklinian Mobile Belt (Fig. 2.1). As Chapter 1 points out, the Franklinian Mobile Belt was the result of convergent plate tectonics during the Silurian to Devonian and, based on Nd isotope and trace element data (Patchett et al., 1999), consists of sediments derived from the underlying Canadian Shield as well as Caledonian sources transported from the direction of present-day Greenland. The overlying Sverdrup Basin is a long-lived, rift-sag sedimentary basin that underwent repeated episodes of active extension and passive subsidence throughout its depositional life (Embry and Beauchamp, 2008; Hadlari et al., 2016). Clastic sediment sources that fed the Sverdrup Basin from 450 to $80 \mathrm{Ma}$ can also be identified on the basis of $\mathrm{Nd}$ and trace element geochemistry; these include the underlying Franklinian Mobile Belt as well as Caledonian sources, with a paucity of clastics from shield sources (Patchett et al., 2004).

South Fiord is located on the northwestern margin of the Strand Fiord Expedition Fiord region on the west central coast of Axel Heiberg Island. Based on analysis of a Landsat-7 mosaic (Fig. 2.2), this region is characterized by a complex valley-and-ridge style topography similar to the Appalachian Mountains of the eastern United States (Williamson et al., 2006). Much of the topographic variation in the Strand 
Fiord - Expedition Fiord area is the result of two distinct geologic processes. The first is continuous intrusion-induced deformation brought on by evaporitic diapirs sourced from the Carboniferous Otto Fiord Formation, a heterogeneous evaporite carbonate unit which exists in the central axis of the Sverdrup Basin (Nassichuk and Davies, 1980; Jackson and Harrison, 2006). It is notable that Axel Heiberg Island and adjacent regions of Canada's far north contain the second highest concentration of exposed evaporite diapirs, exceeded only by Iran (Jackson and Harrison, 2006). The second event to influence topographic variation in the Strand Fiord - Expedition Fiord area occurred in the Eocene when northward movement of Greenland caused compressive deformation and block tilting in Canada's Arctic Islands during the Eurekan Orogeny (Tessensohn and Piepjohn, 2000). 


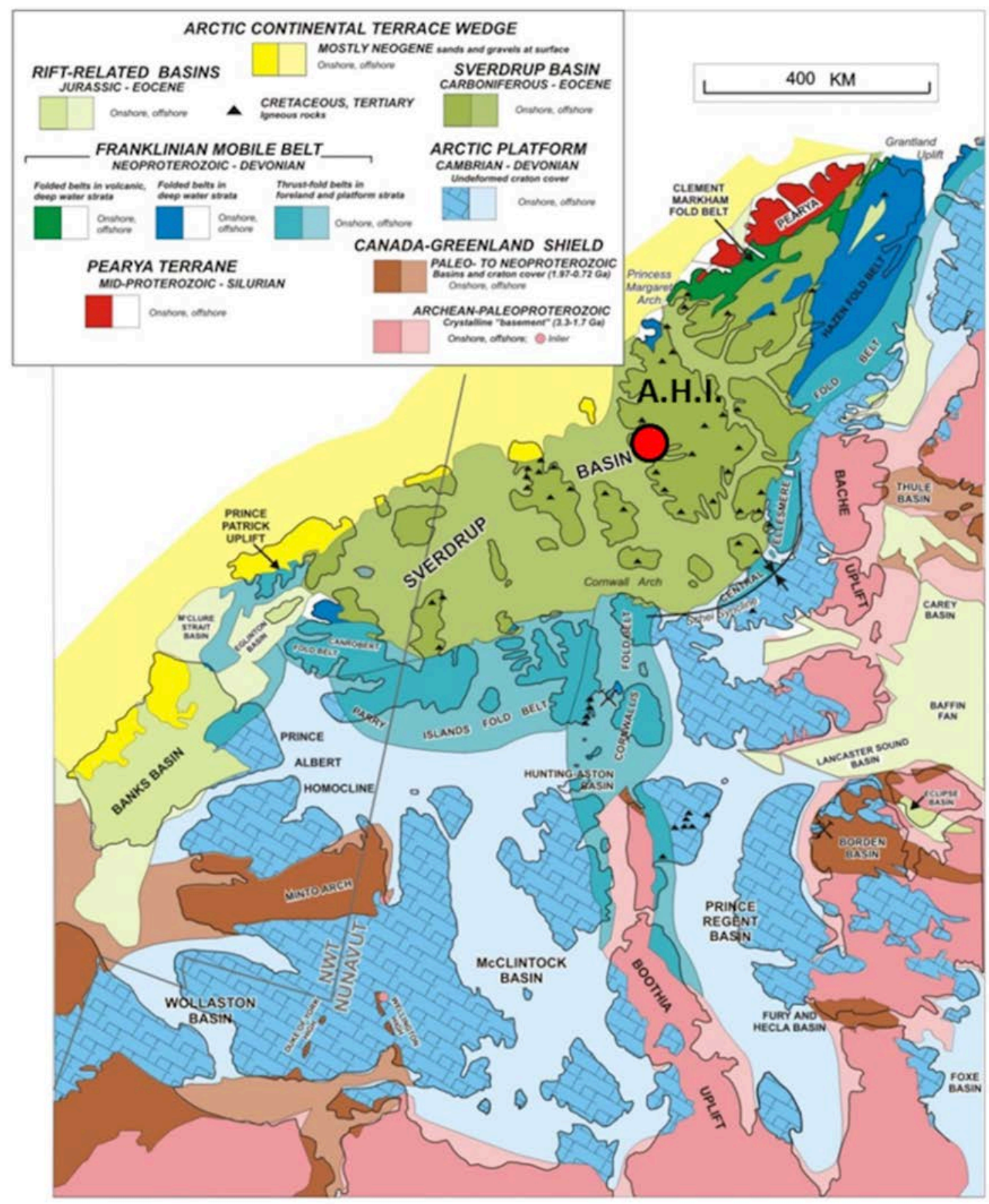

Figure 2.1: Regional geologic map of the Canadian Arctic Islands. A.H.I denotes Axel Heiberg Island and the red circle marks the location of South Fiord field locality, the focus of this study. Figure 2 of Percival et al. (2014). 


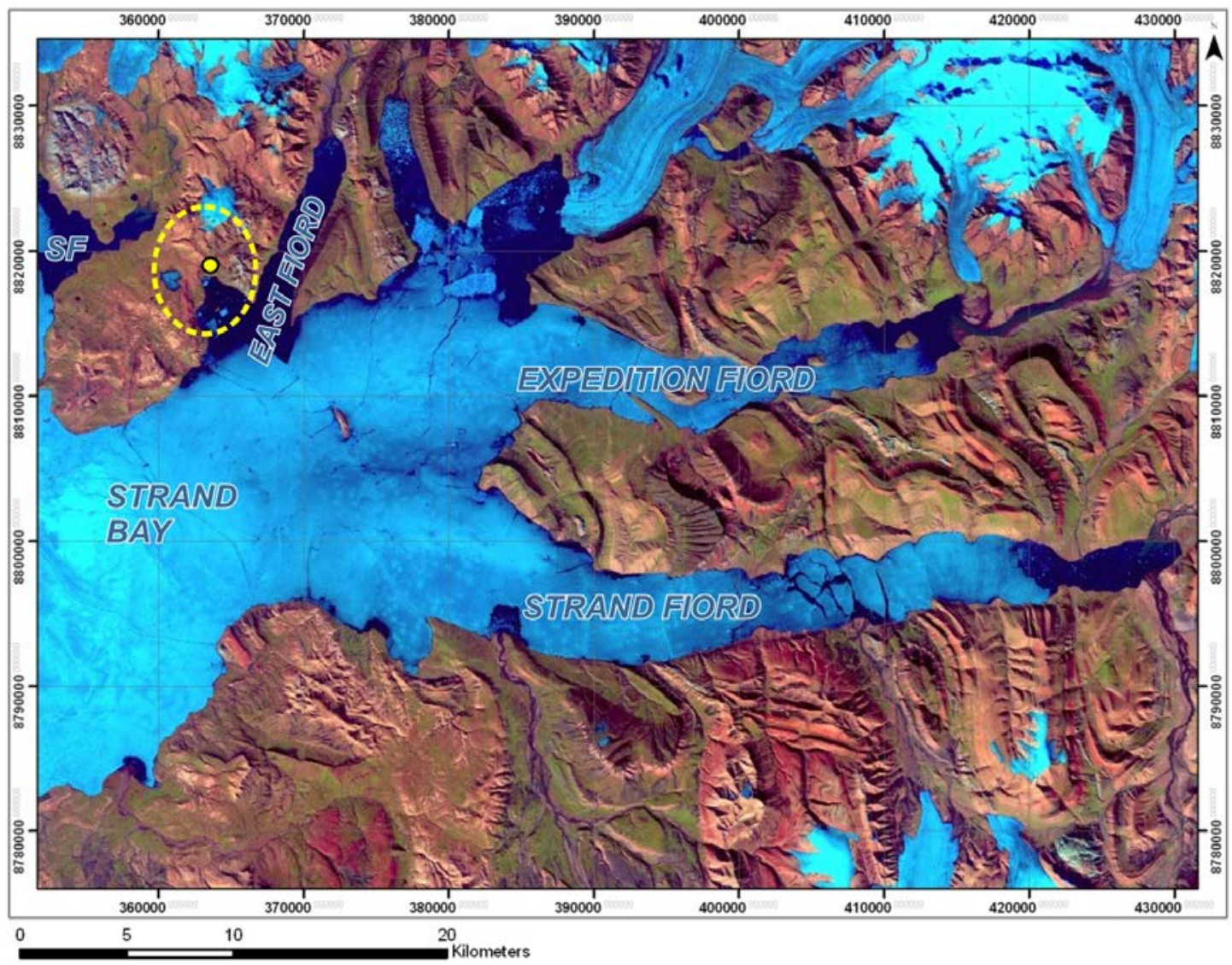

Figure 2.2: Enhanced Landsat-7 TM showing the general topography of the Strand Fiord - Expedition Fiord region on Axel Heiberg Island, Nunavut. Note the prominent valley and ridge-style topography of the region that is situated southeast of the South Fiord 2013 study area. Key to symbols and acronyms: SF = South Fiord; yellow dot $=$ South Fiord base camp; yellow dashed ellipse $=$ foot traverse area. Modified from Williamson et al. (2006). Coordinates are in Universal Transverse Mercator (UTM) Zone 15.

The Strand Fiord - Expedition Fiord area, including the South Fiord field area, is endowed with mafic intrusive units and lava flows which are part of regionally extensive dyke swarms and sill networks that comprise the plumbing system of voluminous Cretaceous volcanic lava flows distributed across Arctic Canada (Ricketts et al., 1985; Williamson, 1988; Buchan and Ernst, 2006; Evenchick et al., 2015; Saumur et al., 2016). Together with mafic dyke swarms and sill provinces in Franz Josef Land, Russia (Dibner, 
1998), Svalbard, Norway and the Barents Sea (Senger et al., 2014; Nejbert et al., 2011;

Polteau et al., 2016) these features are tectonically dismembered remnants of a once contiguous large igneous province (LIP) known as the High Arctic LIP (HALIP) (Drachev and Saunders, 2006; Maher, 2001). There are some data that suggest that HALIP-related sills, dykes and volcanic rocks are also distributed throughout the AlphaMendeleev Ridge region (Petrov et al., 2016; Oakey and Saltus, 2016; c.f. Døssing et al., 2013).

The first (and thus far only) published geologic map which encompasses the entire extent of South Fiord area dates back to 1971 (Fig. 2.3; Thorsteinsson and Tozer, 1971). The authors of this map principally used aerial photos along with spot observations from aircraft - no ground-based work - and from these methods they traced four geologic units within the South Fiord field area: (1) Jurassic-Cretaceous sedimentary rocks of the Savik, Awingak, and Deer Bay Formations (as a single undivided package), (2) Lower Cretaceous Isachsen Formation, (3) evaporite diapirs from the Carboniferous Otto Fiord Formation and (4) mafic intrusive rocks that they interpreted as dykes. More recently, a geologic map of the Strand Fiord - Expedition Fiord region on Axel Heiberg Island was published (Jackson and Harrison, 2010; Fig. 2.4) which improved on the earlier Thorsteinsson and Tozer (1971) map by way of adding sub-divisions of the older units (Savik, Awingak and Deer Bay Formations). The South Fiord region of this study remained unmapped at a suitable scale, and completely lacking in ground-based geological observations that are necessary in order to provide context for analytical work in subsequent chapters. 


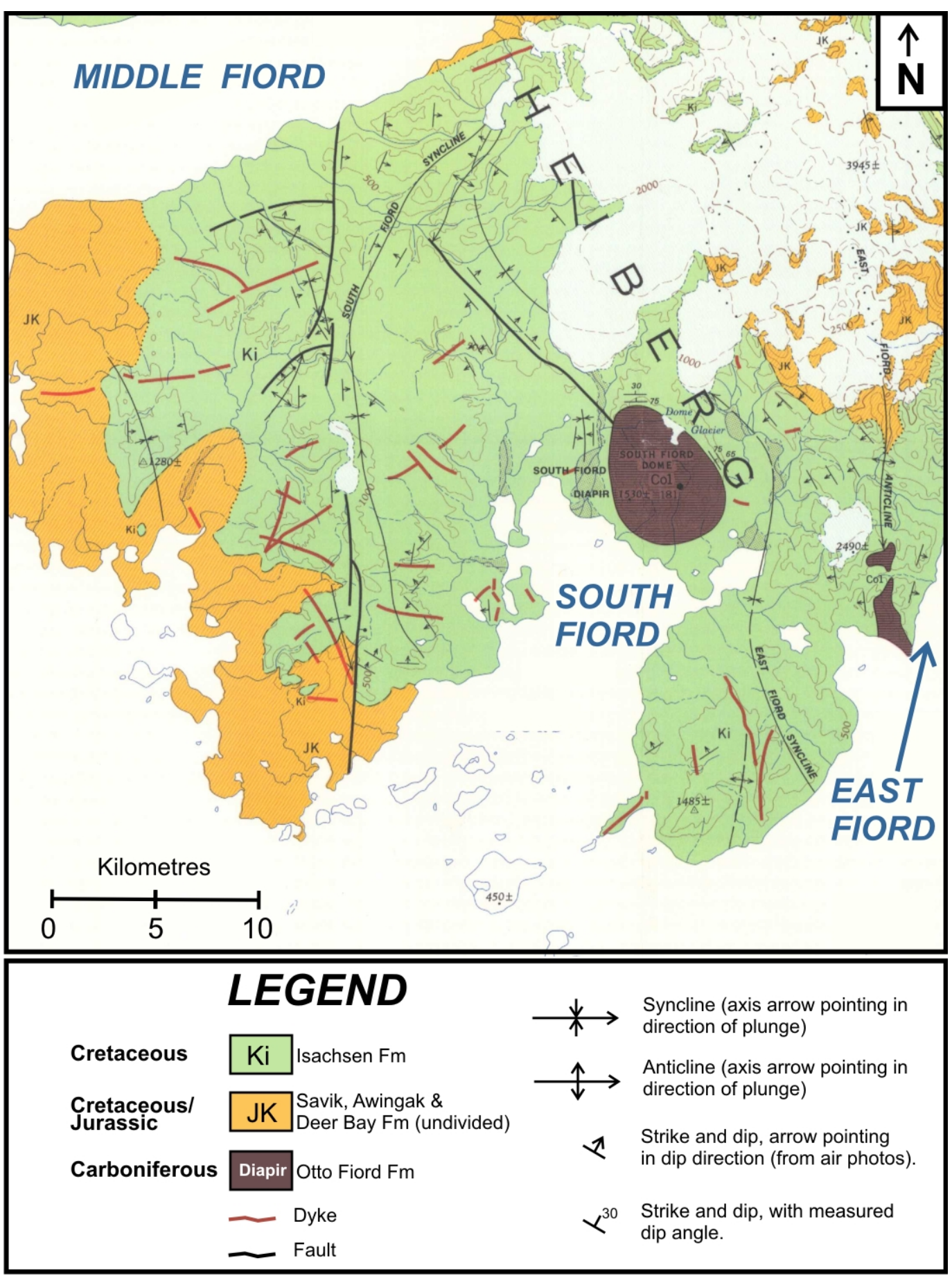

Figure 2.3: Part of the 1:250,000 scale geologic map in the vicinity of South Fiord, Axel Heiberg Island from Thorsteinsson and Tozer (1971). Note that much of the peninsula west of the South Fiord Diapir consists of sedimentary rocks mapped as undivided Isachsen Formation. 


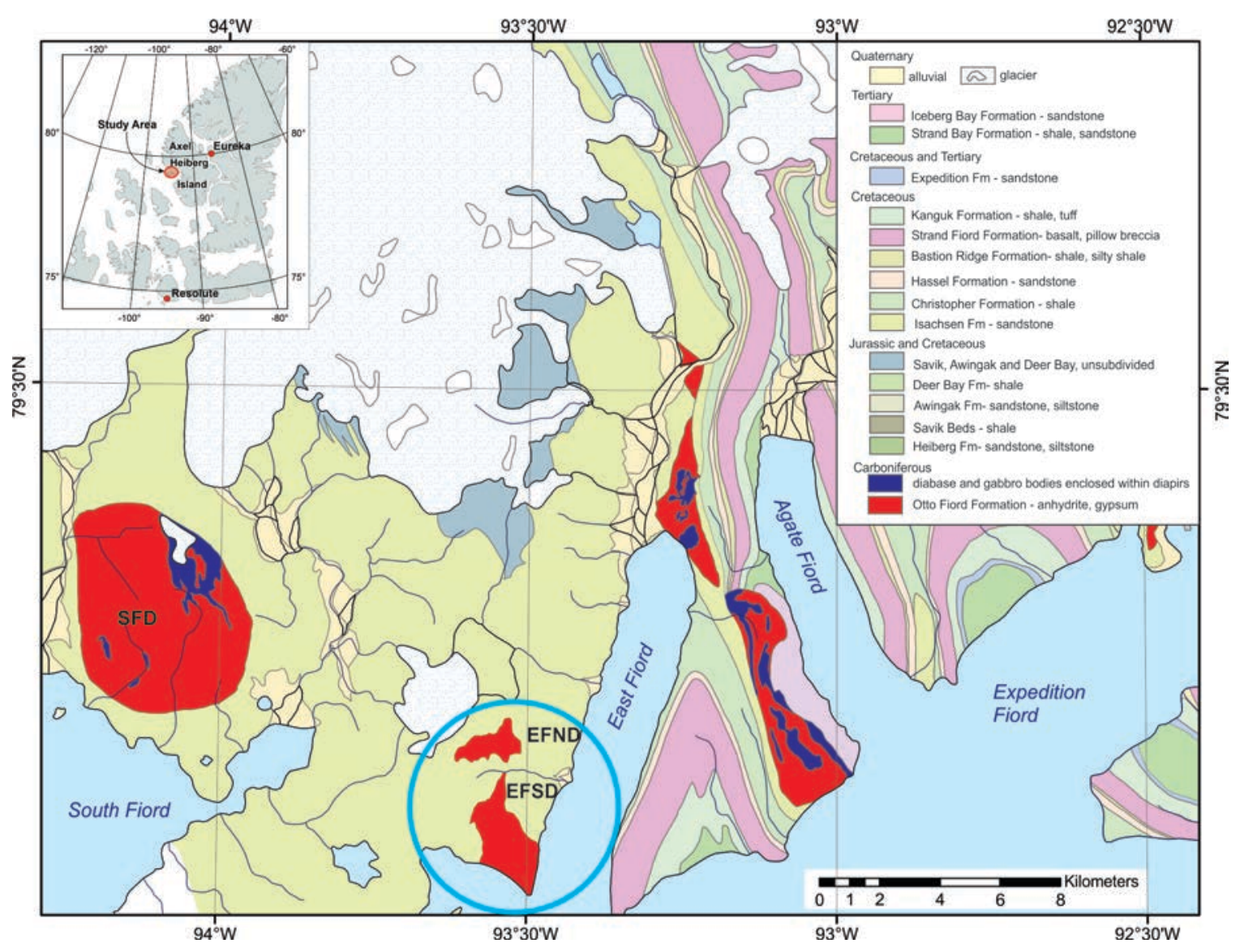

Figure 2.4: Simplified and updated geologic map of East Fiord and the eastern margins of the South Fiord Field locality on Axel Heiberg Island, Nunavut. Key to acronyms: SFD $=$ South Fiord Diapir, EFND = East Fiord North Diapir and EFSD = East Fiord South Diapir. Base map simplified from Jackson and Harrison (2010) as used in Fig. 8 of Williamson et al. (2014). The blue circle represents the "foot traverse area."

The objectives of this chapter will focus on expanding the previous mapping efforts on Axel Heiberg Island by Thorsteinsson and Tozer (1971) and Jackson and Harrison (2010) by using the capabilities of modern remote sensing techniques along with a targeted foot traverse and helicopter-based campaign to produce more detailed mapping of mafic intrusive rocks. The goals of this chapter are twofold: (1) document and describe the emplacement style of mafic intrusive structures (dyke vs. sill) in the South Fiord region, as well as mafic lava flows within the Isachsen Formation and (2) to produce a map of the geology in the South Fiord locality using a combination of field 
observations as well as high resolution satellite imagery with a particular focus on the geometry of intrusive bodies. This map will (a) provide details of the HALIP units in an area not previously mapped in detail (e.g. Saumur et al., 2016; Williamson et al., 2016; Evenchick et al., 2015) and (b) provide a context for the geochemical analyses and age determinations on the magmatic intrusions (dykes and sills) and lava flows in subsequent chapters.

\subsection{FIELD METHODS}

Over four weeks in July of 2013, a team of researchers from the Geological Survey of Canada and myself conducted a multi-disciplinary geoscience investigation surrounding South Fiord in order to investigate mafic igneous rocks, evaporite diapirs and permafrost-influenced base-metal gossan development through mineralogy and stream sediment geochemistry (Kingsbury et al., 2014). Fieldwork involved traverses covering a $\sim 2 \mathrm{~km}$ radius surrounding a base camp pitched close to the western periphery of East Fiord South Diapir (here after termed the "Foot Traverse Area"). Additional samples of mafic rock were collected by helicopter on the $20 \mathrm{~km}$ x $30 \mathrm{~km}$ peninsula ("Helicopter" peninsula) due west of South Fiord Diapir as well as the smaller peninsula to its south. Sample collection sites were located using handheld GPS. Field observations (Field Notes in Appendix A) and photographs were used to document field relations between lithological units and outcrop characteristics, which were then used to construct a more detailed geologic map focusing on the intrusions of igneous rocks. 


\subsection{FIELD CHARACTERISTICS}

Figure 2.5 is a hillshade terrain map of the South Fiord field area derived from a digital elevation model (DEM) supplied by Natural Resources Canada (http://geogratis.gc.ca/api/en/nrcan-rncan/ess-sst/C40ACFBA-C722-4BE1-862E146B80BE738E.html) showing the general topography of South Fiord. For a relatively small geographical region, the South Fiord field area contains a diverse array of landform features including ridges, valleys and domes (Fig. 2.5).

Over much of the two peninsulas, including the Helicopter Peninsula, west and south of the South Fiord Diapir, the landscape is characterized by plateau-like topography with intervening "v-shaped" valleys that channel seasonal streams of snowmelt runoff. This plateau-like topography is chiefly controlled by the sub-horizontal orientation of the underlying sedimentary beds with the more resistant beds forming prominent cliffs. In a number of locations, the sub-horizontal sedimentary rocks are cut by mafic dykes that are predominantly less than $5 \mathrm{~m}$ in width (Fig. 2.6) as well as cut by sills that vary in thickness from $\sim 5 \mathrm{~m}$ to greater than $50 \mathrm{~m}$ (Fig. 2.7). 


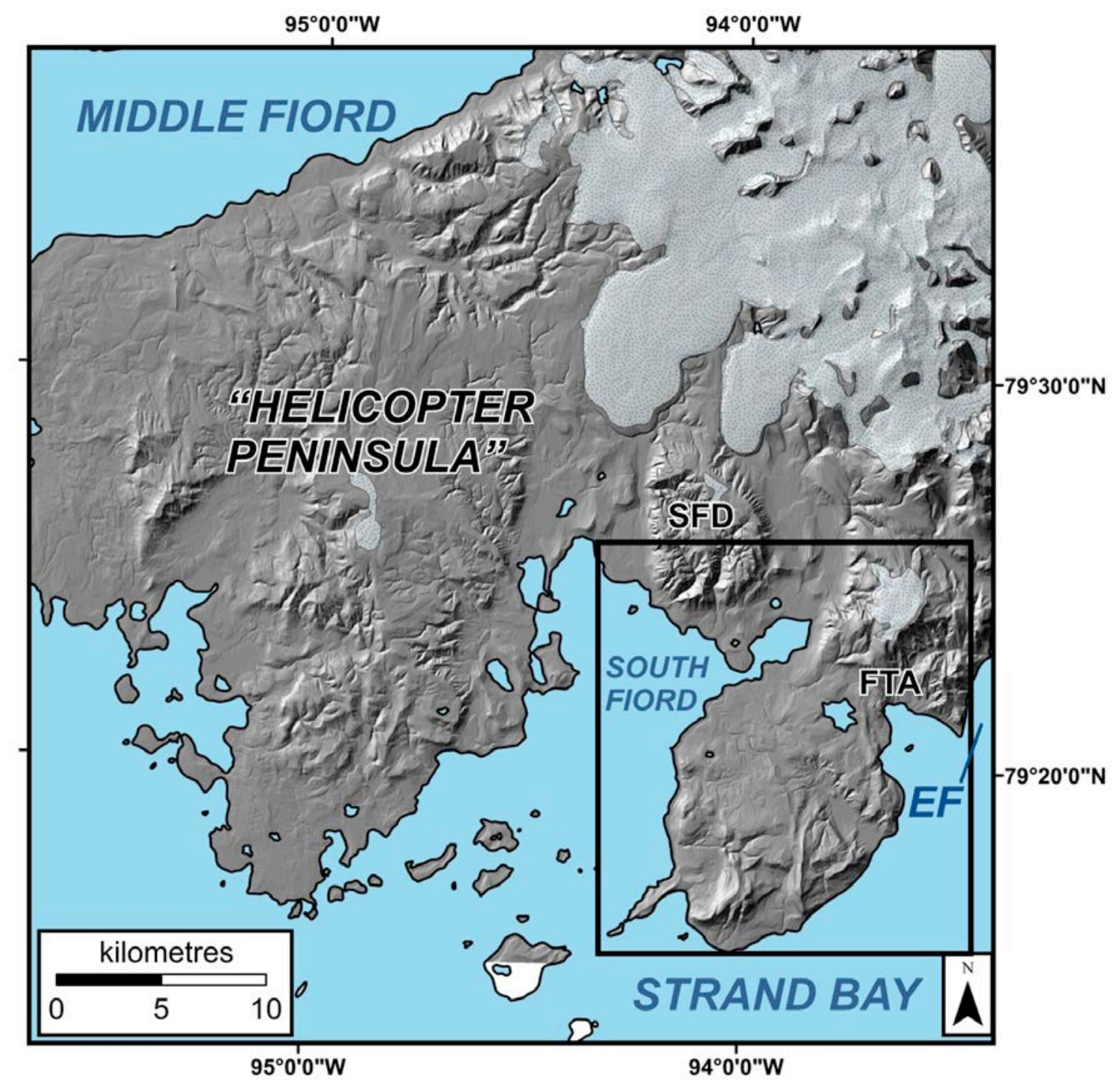

Figure 2.5: Digital Elevation model (DEM) of the South Fiord region showing general topography as a hillshade with water masked in blue. The DEM was supplied by Natural Resources Canada. Stippled pattern mostly concentrated in the northeastern part denotes glaciers and the dome east of the figure's centre is the South Fiord Diapir (SFD). Black box in southeast represents extent of Figures $2.11 \& 2.17$ in this chapter. FTA $=$ Foot Traverse Area, EF = East Fiord. The stippled area in the northeast of this figure, denotes glaciers. 


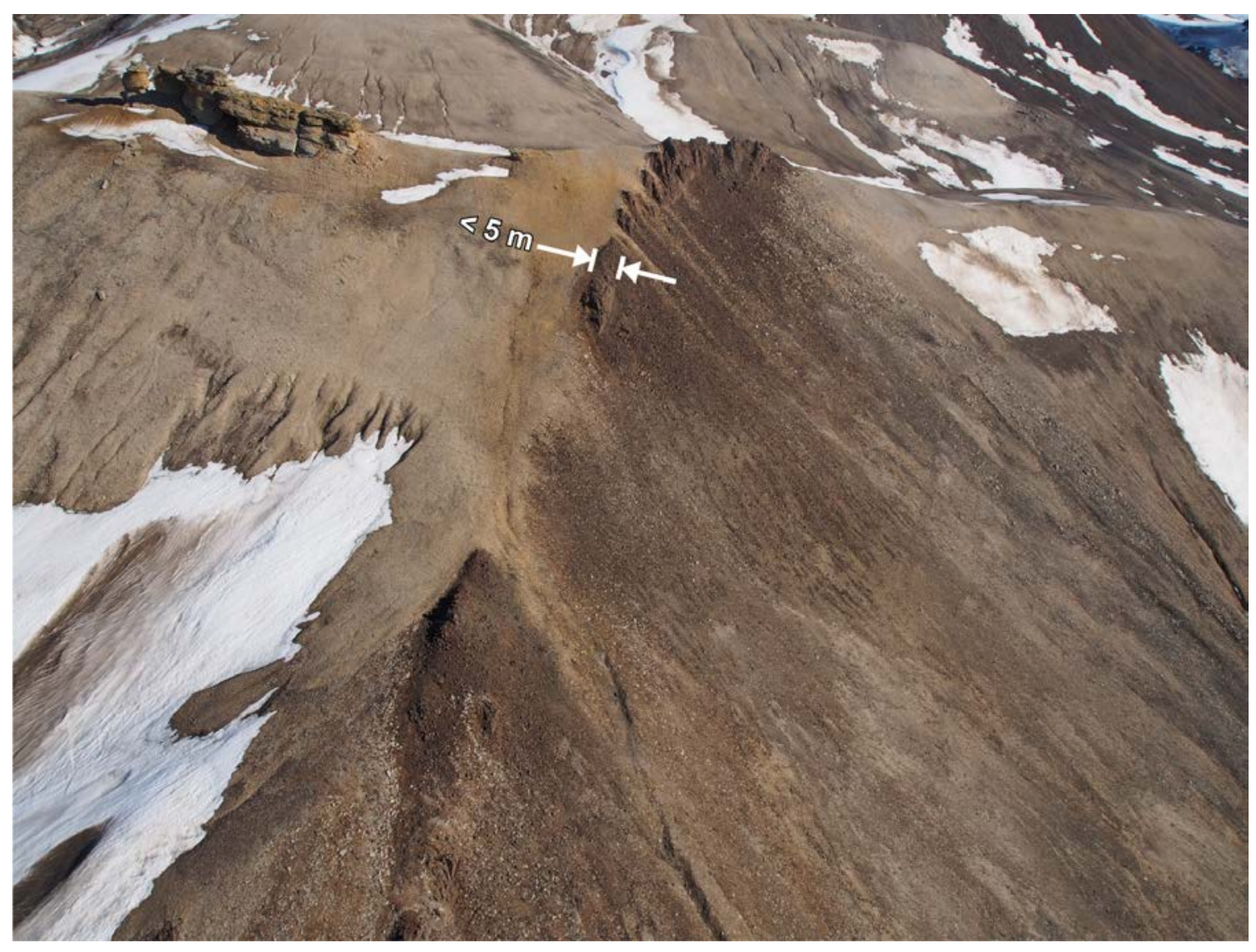

Figure 2.6: Oblique aerial photo showing a thin $(<5 \mathrm{~m})$ dark coloured dyke cutting lightcoloured sedimentary rocks of the Isachsen formation. 


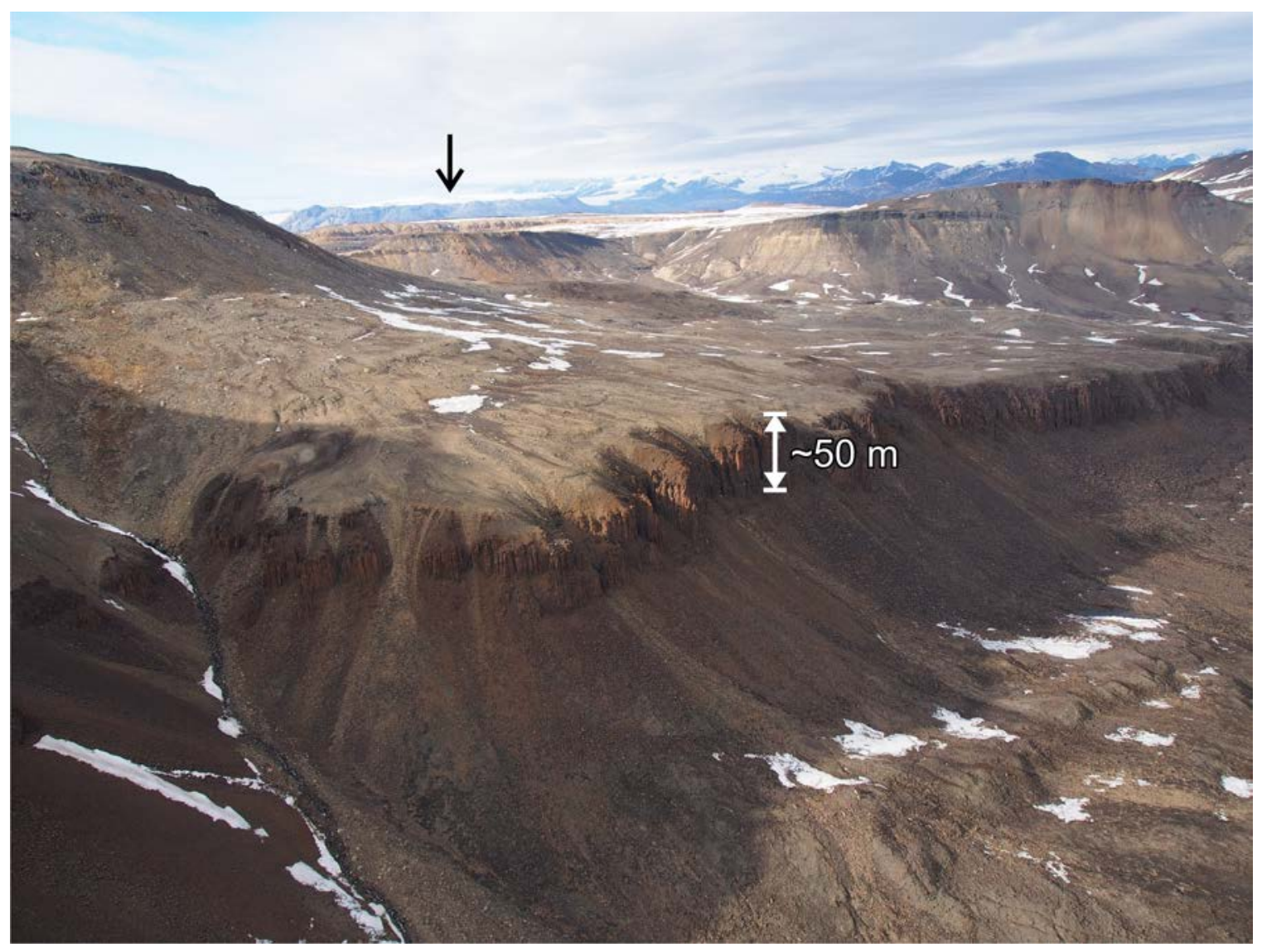

Figure 2.7: Oblique aerial photo showing a dark coloured $~ 50 \mathrm{~m}$ thick sill intruding light-coloured sedimentary rocks of the Isachsen Formation in the image foreground. North is towards the background. Note the ensemble of vertical columnar joints. Black arrow points to the South Fiord Diapir in the far background. This is sill S11 in Table 2.2

In contrast to the plateau-style relief characterizing points west and south of the South Fiord Diapir, the topography surrounding the East Fiord South Diapir (elevation $\sim 320 \mathrm{~m}$ ) has high relief (Fig. 2.8), thereby marking the western limits of the intense valley-and-ridge style topography seen in the Strand Fiord - Expedition Fiord region of Axel Heiberg Island that then transitions into the plateau style relief in the "Helicopter Peninsula' (Fig. 2.5). Much of what characterizes the geomorphology around the periphery of East Fiord South Diapir (Fig. 2.8) can be described as a series of ridges that 
are heavily mantled with talus slopes predominantly comprising disaggregated boulders of mafic rocks with minor sandstones.

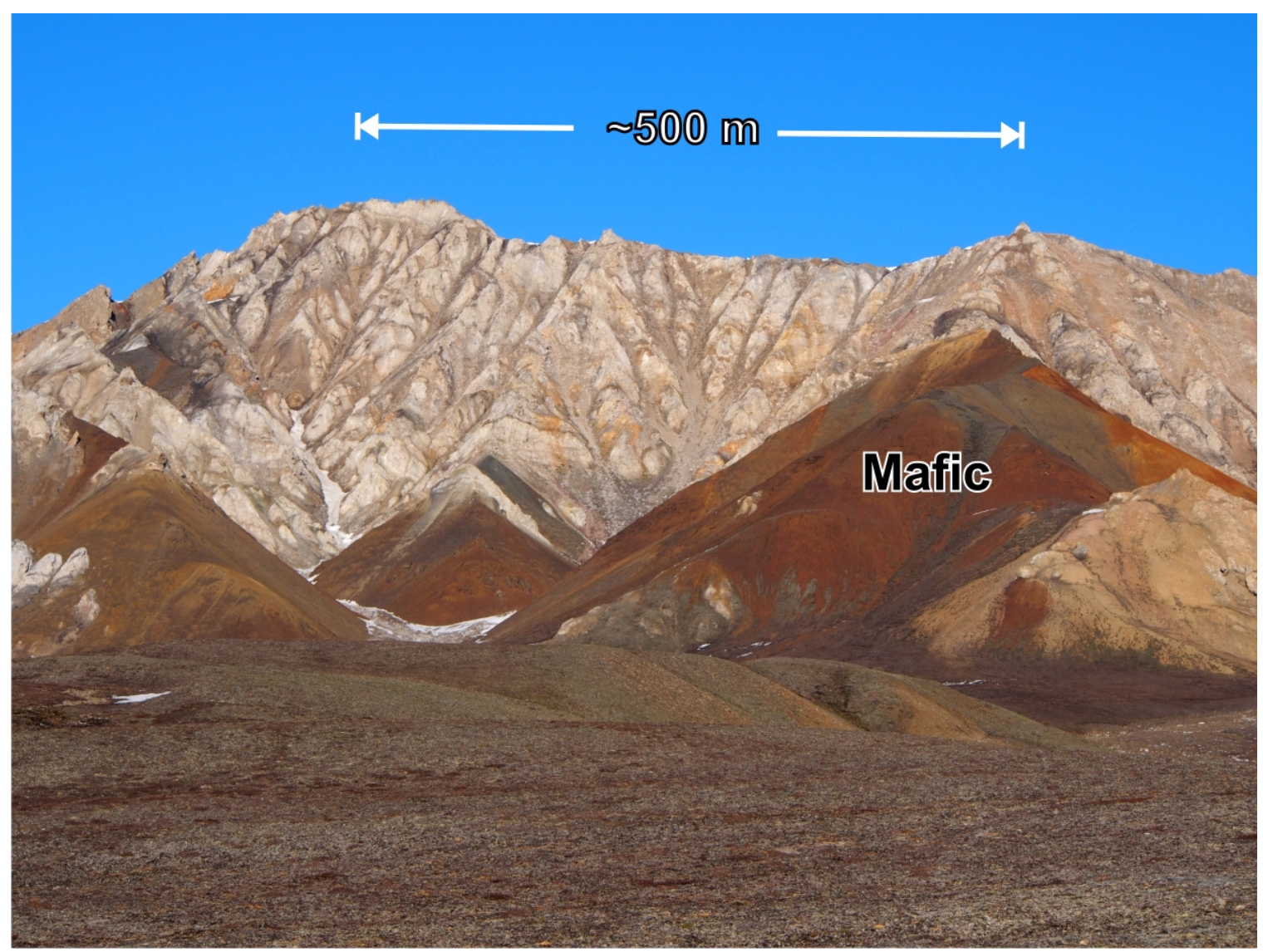

Figure 2.8: Ground-based photo, looking east, showing light coloured East Fiord South Diapir which is intruding and disaggregating dark-coloured mafic rocks (labeled) forming talus aprons on the middle to lower slopes.

A prominent physical characteristic is the stark colour contrasts between mafic units on the one hand, and sedimentary rocks and evaporites on the other (Figs. 2.6-2.8). Sedimentary sequences, especially sandstones which outcrop prominently in many locations and can serve as sedimentary marker beds, are typically buff-coloured in light shades of yellow and orange. Evaporites (Fig. 2.8) are also a light shade though the 
colour is more uniformly buff. In contrast, mafic rocks that outcrop in the field area are very dark shades of grey, red and orange. The colour contrasts and spectral differences noted above are important for geological mapping based on remotely sensed imagery (e.g. Behnia et al., 2012).

\subsection{REMOTE SENSING FOR GEOLOGICAL MAPPING}

Effective geological application of remote sensing in the South Fiord region is possible chiefly due to the lack of significant vegetation that results due to the polar climate. This allows satellite sensors to image bedrock directly, that in turn (1) permits selecting a field location that maximizes scientific potential in terms of characterizing mafic intrusions and their relationships to country rock prior to the commencement of fieldwork, and (2) enable the construction of geologic maps using the imagery as a base upon completion of fieldwork. This represents what is referred to remote predictive mapping (Behnia et al., 2012; Harris et al., 2012).

Ground truthing during the field campaign then provided the opportunity to crosscheck the broad lithology type (mafic igneous vs. sedimentary) seen on satellite imagery with that based on field observations. Utilizing remote predictive mapping for the broad lithology determinations allowed fieldwork to strategically focus on aspects that cannot be detected via remote sensing, such as whether or not a particular mafic unit is a sill, dyke, or a lava flow using textural and physical characteristics such as the orientation of columnar jointing or the abundance of vesiculation. While the National Earth Observation Data Framework Catalogue of Natural Resources Canada's National Airphoto Library (https://neodf.nrcan.gc.ca/neodf_cat3/index.php?lang=en) does show 
that airphotos do exist for the South Fiord area, these are black and white. Instead, multispectral satellite imagery was chosen to provide a more realistic representation of the field characteristics, and in the case of SPOT-6 that is discussed below, was customacquired in order to control for and minimize snow-cover, shadows and clouds to provide the best possible imagery for multispectral-based mapping.

All remote sensing analysis in this thesis was done within the geographic information system, ArcGIS $\AA_{\text {v. }}$ 10.1. Initial remotely-sensed investigations of the South Fiord area were carried out with Landsat -7 imagery (Fig. 2.9) which has spatial resolution of $30 \mathrm{~m}$ (Wilford and Creasey, 2002). True-colour imagery (Fig. 2.9) of South Fiord revealed lighter regions and darker regions. The lighter regions, which are concentrated chiefly in the 'Helicopter Peninsula' (Fig. 2.9), appear to be sedimentary rocks and local evaporite domes when cross-referenced with the geological map (Thorsteinsson and Tozer, 1971; Fig. 2.3). Darker areas imaged by Landsat may be either mafic rocks or, in low-lying areas, vegetation.

The second satellite system used for geologic remote-sensing was the Advanced Spaceborne Thermal Emission and Reflectance Radiometer (ASTER) sensor (National Atmospheric and Space Administration, 2004). Figure 2.10 shows the South Fiord region via ASTER-satellite imagery. The ASTER sensors improve the true-colour imagery of Landsat-7 on two fronts: the first is that the three visual to near infrared (VNIR) bands have a spatial resolution of $15 \mathrm{~m} / \mathrm{pixel}$ (National Atmospheric and Space Administration, 2004) thereby doubling the resolution capable using Landsat-7 TM. The second is that the imagery provides a near-photorealistic representation of the area: vegetation is vibrant-green (since the image was acquired in late summer), mafic rocks manifest as 
dark-red, -orange or -grey zones, and sedimentary rocks and evaporite diapirs are buff, tan to light orange (Fig. 2.8)-all similar to their visual colour characteristics in the field. Furthermore, with the improved spatial resolution ( $15 \mathrm{~m} / \mathrm{pixel})$, smaller-scale features may be seen, including the thicker mafic dykes that can be seen cross-cutting the sedimentary rocks within the 'Helicopter Peninsula'.

In addition to the Landsat-7 TM and ASTER imagery that are described above, $1.5 \mathrm{~m} /$ pixel SPOT-6 data (Satellite Imaging Corporation, 2005) was acquired that focused on the detailed field area along with portions of the South Fiord Diapir and points due south (Fig. 2.11). One observation that can be made on the SPOT-6 imagery is that sedimentary rocks, which have a generally buff to tan coloration appearance in SPOT-6, show shifts in colour tone that correspond to variations in lithology in the peninsula south of the South Fiord Diapir. Thus, using imagery derived from the sensors aboard SPOT-6 makes it possible not only to discriminate between major lithology variations such as sedimentary rocks from mafic rocks, as is also possible with the ASTER and Landsat-7 TM imagery, but that individual lithological variations within sedimentary sequences are also detected. This step in resolution would aid in determining the intrusive style of mafic rocks (this study) along with divisions of sedimentary beds (future mapping). 


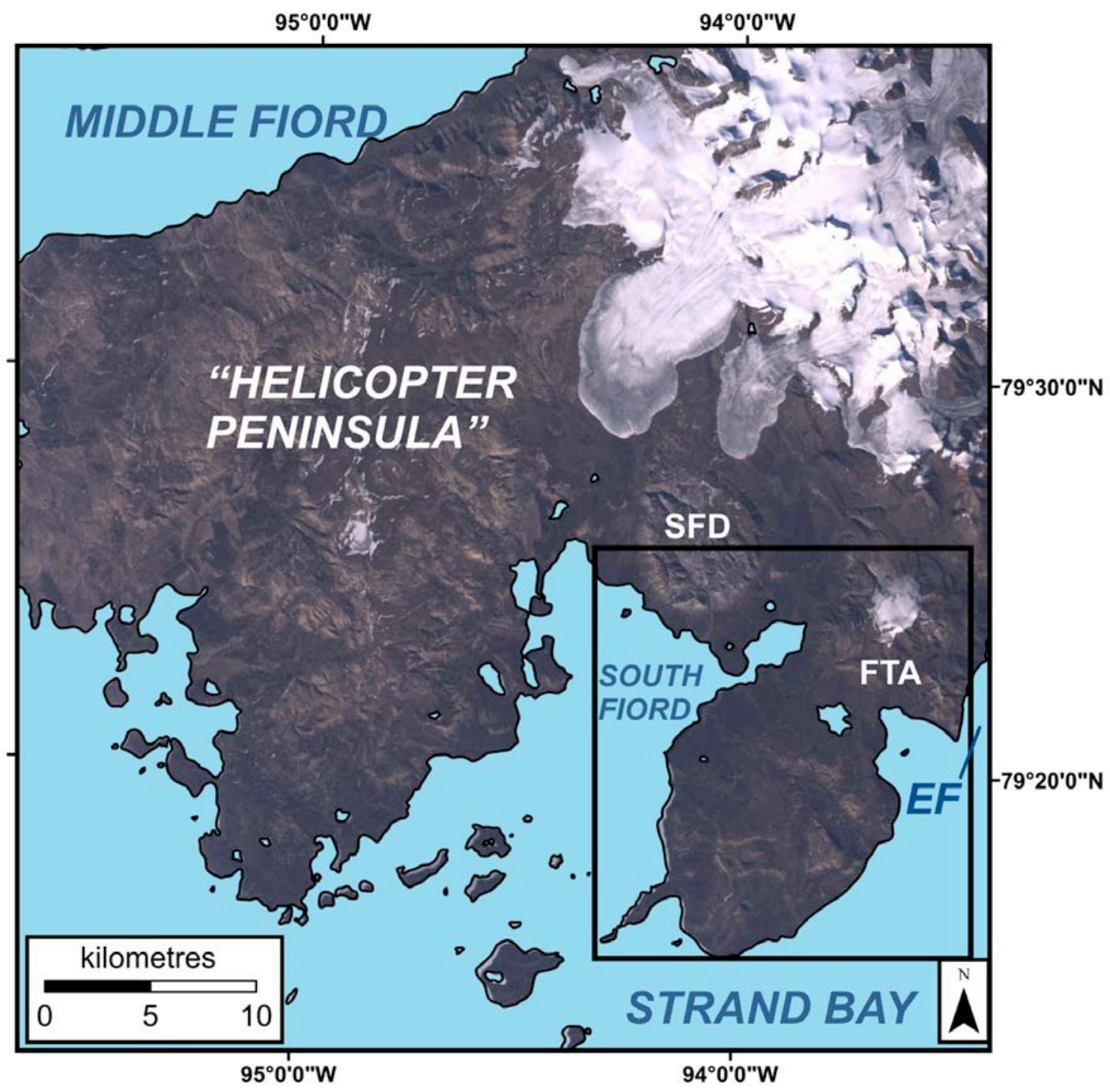

Figure 2.9: True colour Landsat-7 Thematic Mapper image of the South Fiord region including the "Helicopter Peninsula" (see text) with water masked in blue. Multi-spectral bands 3, 2 and 1 are entered into in the Red, Green and Blue channels, respectively. The dome east of the figure's centre is the South Fiord Diapir (SFD). Black box in southeast represents extent of Figures $2.11 \& 2.17$ in this chapter. FTA $=$ Foot Traverse Area, EF = East Fiord. The stippled area in the northeast of this figure, denotes glaciers. 


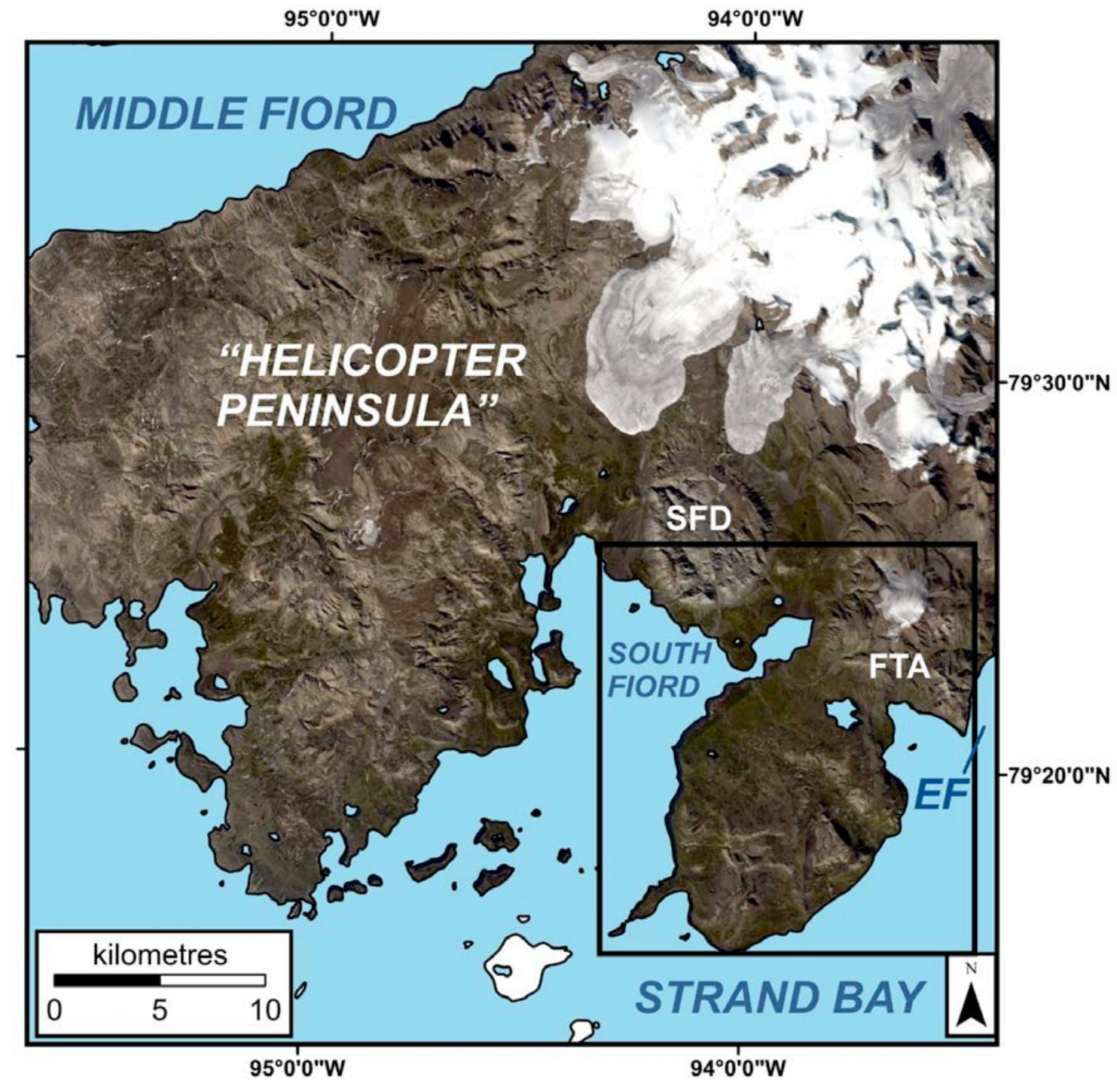

Figure 2.10: True colour ASTER image of the South Fiord region including the "Helicopter Peninsula" (see text) with water masked in blue. Multi-spectral bands 1, 2 and 3 are entered into in the Red, Green and Blue channels, respectively. The dome east of the figure's centre is the South Fiord Diapir (SFD). Black box in southeast represents extent of Figures $2.11 \& 2.17$ in this chapter. FTA $=$ Foot Traverse Area, EF = East Fiord. The white area in the northeast of this figure denotes glaciers. 


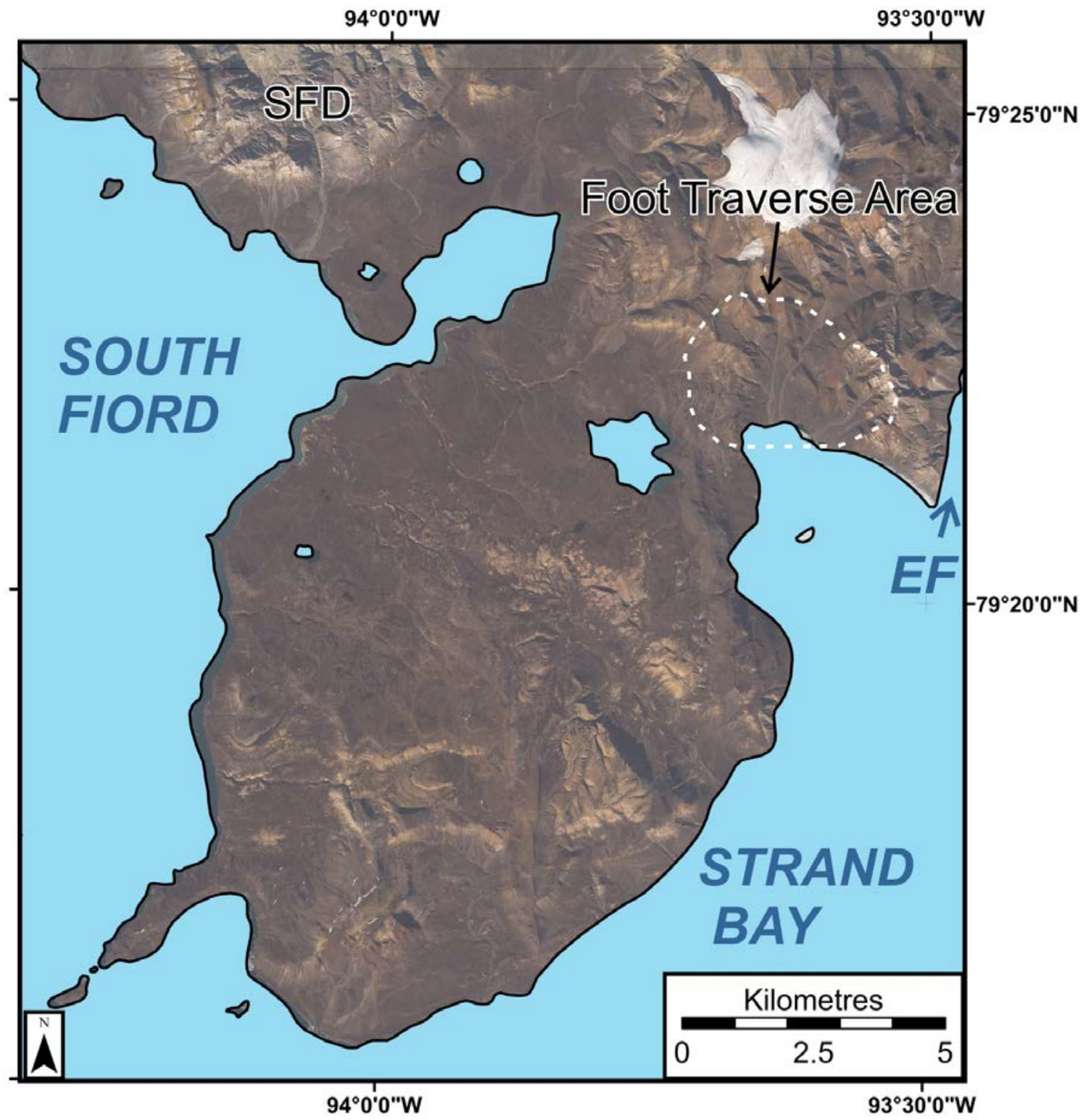

Figure 2.11: True-Colour SPOT-6 imagery of a portion of the South Fiord region located south and southwest of the South Fiord Diapir where foot traversing and select helicopter supported sample collection took place. Water is masked in blue. Key to abbreviation, EF $=$ East Fiord; SFD $=$ South Fiord Diapir. The white area in the northeast of this figure is a glacier.

The vast majority of the 2013 field season was spent mapping and collecting bedrock samples focused on the periphery of the East Fiord South Diapir in order to support concurrent Geological Survey of Canada studies on gossans (e.g. Williamson et 
al., 2014), hydrochemistry and stream sediment geochemistry (McNeil et al., 2014).

Therefore, some samples collected for this thesis were collected at the same locality as gossans. As Figure 2.12 demonstrates, this frequently involved collecting bedrock material in a topographically challenging location due to diapir-related disaggregation of the surrounding sedimentary and mafic rocks. The high topography in concert with talus slopes necessitated sample collection within a smaller geographic area than would have been permitted in more topographically subdued areas such as the "Helicopter Peninsula." Unfortunately, the Helicopter Peninsula was largely snow-covered at the time of 2013 field season. The SPOT-6 data acquisition was primarily focused on coverage for this complicated area, as well as the peninsula south of the South Fiord Diapir where one sample was collected for a U-Pb age determination (Chapter 4).

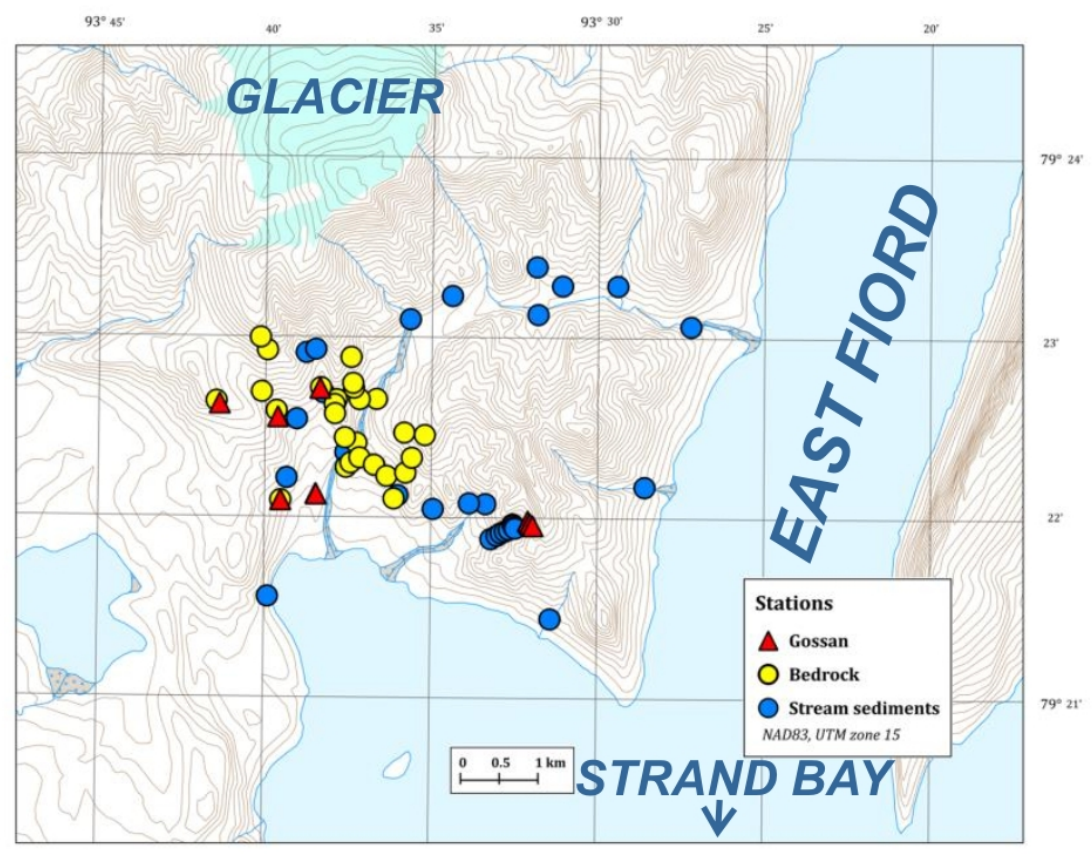

Figure 2.12: Topographic map of the foot traverse portion of the South Fiord field site on Axel Heiberg Island, Nunavut showing locations for bedrock sampling (this study) as well as gossan (Percival et al., 2014; Williamson et al., 2014) and stream sediments (McNeil et al., 2014). Figure from McNeil et al. (2014) and Williamson et al. (2014). 
Each of the three sensor types introduced above has advantages and drawbacks in terms of spatial resolution and spectral richness. To compare detailed mapping using SPOT-6 imagery with Landsat-7 and ASTER imagery, Figure 2.13 shows data from all three sensors (true-colour on each) at the Cuesta Ridge locality. At the common scale used, Landsat-7 (Fig. 2.13A) is highly pixelated, having spatial resolution of $30 \mathrm{~m}$ and in true-colour is not very spectrally rich (United States Geological Survey, 2015) making it hard to identify local characteristics such as outcrop quality and to differentiate between individual lithological units in complex regions. ASTER imagery (Fig. 2.13B) improves on Landsat in that the true-colour image has better colour contrast, and the spatial resolution $(15 \mathrm{~m})$ is doubled in comparison with Landsat-7 data. Significant progress in mapping complex regions like the South Fiord area is facilitated by using the capabilities of SPOT-6 (Fig. 2.13C) which has still greater spectral richness and a spatial resolution of $1.5 \mathrm{~m}$ (Satellite Imaging Corporation, 2005) and as a result, allows mapping of individual lithological units at the Cuesta Ridge site. Table 2.1 compares the spatial resolution and spectral information from these sensors.

Given its greater resolution and spectral richness, SPOT-6 imagery is used for the purpose of producing an initial geologic map that focuses on the distribution of dykes, sills, lava flows that intrude within or erupt over sedimentary rocks comprising the country rock present in the foot traverse area and the peninsula south of the South Fiord Diapir (see Section 2.6). 
Table 2.1: Satellite sensor comparisons of bands used for this study.

\begin{tabular}{|l||l|l|l|}
\hline \multicolumn{1}{|c||}{} & Landsat -7 & ASTER & SPOT - 6 \\
\hline \hline Spatial Resolution & $30 \mathrm{~m}$ & $15 \mathrm{~m}$ & $1.5 \mathrm{~m}$ \\
\hline Spectral wavelength (in $\mu \mathrm{m})$ & & & \\
\hline Band 1 & $0.45-0.52$ Blue & $0.52-0.60$ Green & $0.46-0.53$ Blue \\
\hline Band 2 & $0.52-0.60$ Green & $0.63-0.69$ Red & $0.53-0.59$ Green \\
\hline Band 3 & $0.63-0.69$ Red & N/A & $0.63-0.70$ Red \\
\hline Band 3N (Nadir) & N/A & $0.76-0.86$ NIR & $0.76-0.89$ NIR \\
\hline Band 3B (Backward) & N/A & $0.76-0.86$ NIR & N/A \\
\hline Reference & USGS (2015) & NASA (2004) & SIC (2005) \\
\hline
\end{tabular}

Notes:

NIR = Near infrared

$\mathrm{N} / \mathrm{A}=$ Not applicable

$\mathrm{SIC}=$ Satellite Imaging Corporation

Band numbers keyed only for Landsat and ASTER.

SPOT 6 Bands arranged in ascending wavelength order and not connected to Band \#

\subsection{STRATIGRAPHY}

As a general rule the field relations between igneous intrusions and the sedimentary country rock are unclear within the foot-traverse area due to extensive aprons of talus mantling ridge and mountain slopes that cover lithologic contacts. However, the Cuesta Ridge stratigraphic section exposes a sequence of coherent sedimentary beds and lava flows with excellent outcrop exposure (Fig. 2.14) allowing for first-order stratigraphic characterization of the rocks that comprise the South Fiord field site. Ground based observations, along with analysis of SPOT imagery, reveal no direct connection between the lavas present at Cuesta Ridge with the plumbing system exposed in South Fiord. Furthermore, no field evidence was found that allowed assessment of their flow direction. All sedimentary rocks in the detailed field area belong to the Isachsen Formation (Jackson and Harrison, 2010; Thorsteinsson and Tozer, 1971). 

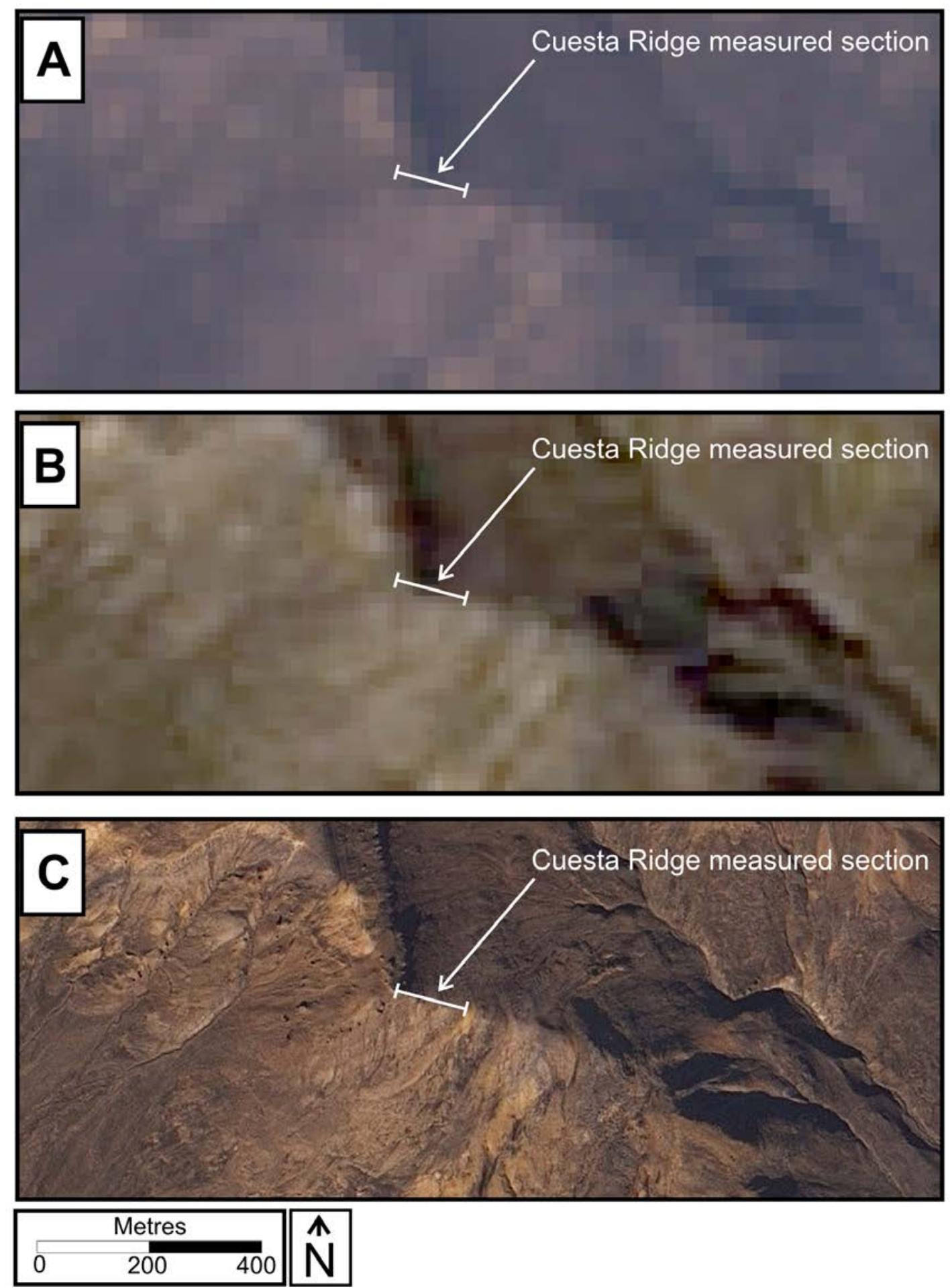

Figure 2.13: Comparative satellite imagery of the Cuesta Ridge stratigraphic section showing the distinction in resolution and spectral characteristics of (a) $30 \mathrm{~m}$ pixel resolution Landsat-7; (b) $15 \mathrm{~m}$ pixel resolution of ASTER and (c) $1.5 \mathrm{~m}$ pixel resolution SPOT-6. Note that many individual sedimentary beds along with details about outcrop quality can be resolved at the resolution SPOT-6 offers but not Landsat-7 or ASTER. 


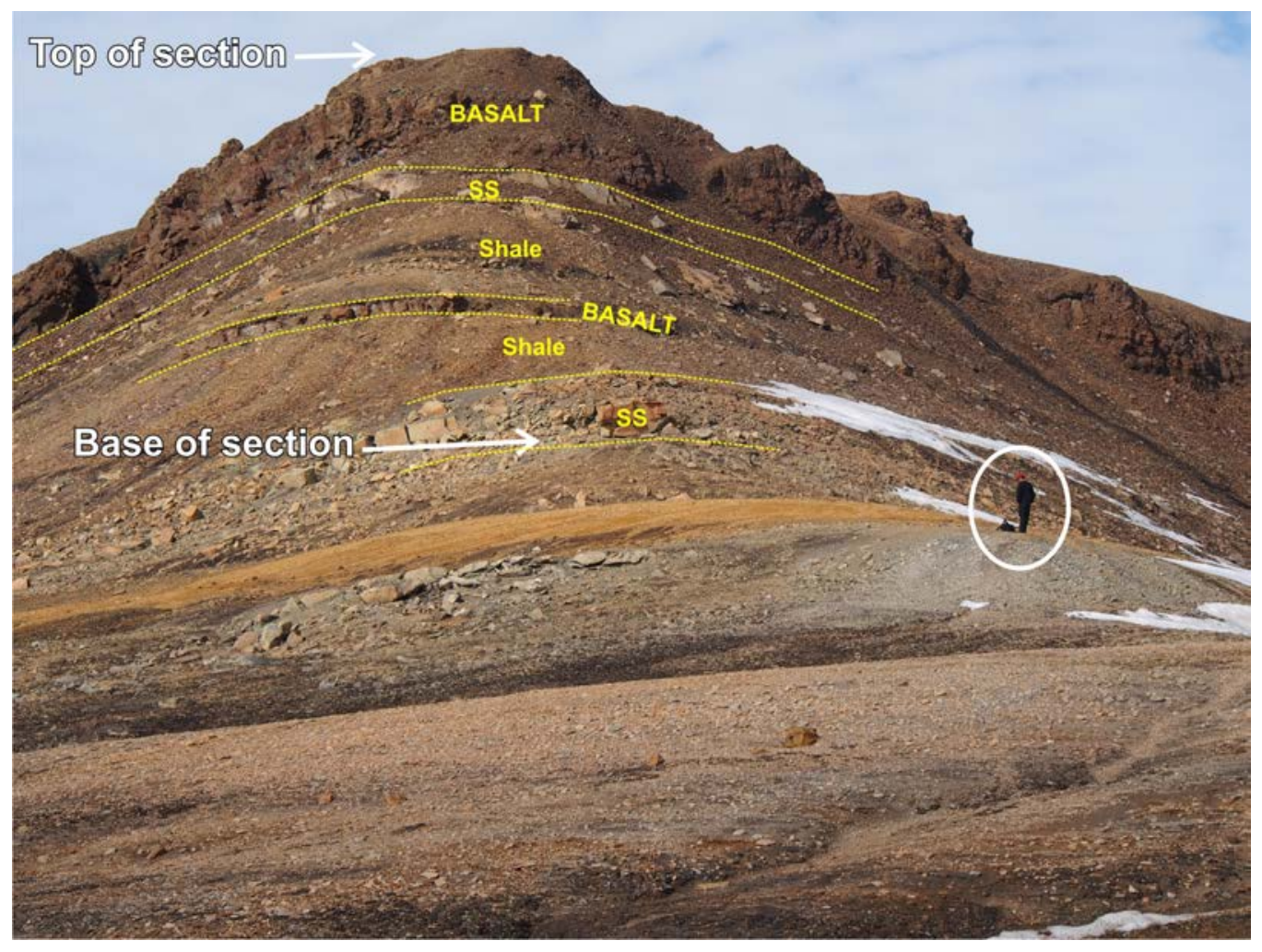

Figure 2.14: Ground-based photograph showing the Cuesta Ridge stratigraphic section. For scale note the author is present to the centre-right of the image (circled; $2 \mathrm{~m}$ ). Note the distinctive differences in outcrop behaviour between prominently-cropping sandstone (SS) and basaltic lavas on the one hand with recessive shale units on the other.

Furthermore, note the visual differences between the dark-coloured basaltic flows with the buff-coloured sandstones.

The Cuesta Ridge stratigraphic column is shown in Figure 2.15 and features two sub-aerial lava flows which were identified as flows on the basis of (1) pahoehoe casts at the base of the thin sandstone in contact above the lower flow and (2) the presence of scoriaceous tops on a second lava flow. The two lava flows measure $2 \mathrm{~m}$ and $10 \mathrm{~m}$ in thickness, respectively.

The Cuesta Ridge flows erupted over an Isachsen Formation sedimentary sequence that is dominated by quartzose sandstone and shales which broadly characterize both the Paterson and Walker Island Members of the Isachsen Formation (Tullius et al., 
2014). The similarities in lithologic assemblages between the Paterson and Walker Island Members raises questions as to which of the two sedimentary sequences are exposed on Cuesta Ridge. The most recent published map which includes part of the South Fiord area (Jackson and Harrison, 2010) does not subdivide the Isachsen Formation into its constituent members. Nonetheless inferences may be made as to which member of the Isachsen Formation exists within the South Fiord area on the basis of the presence of volcanic rocks. In Figures 4a \& b of Embry and Osadetz (1988) they show a thicknesscalibrated geographic distribution map of volcanic rocks associated with the Paterson and Walker Island Members and note that the southern limit of the exposed extent in the Paterson Island Member (e.g. "zero line") is north of the South Fiord field area whereas the "zero line" of Walker Island Member volcanic rocks is well south of the South Fiord field area. However the Paterson Island Member is mapped on Ellef Ringness Island, significantly southwest of the Paterson Island Member "zero line" of volcanic lavas from Embry and Osadetz (1988) that contain a locality of volcanogenic rocks but no apparent lavas (Evenchick et al., 2015). This leads to a tentative conclusion that Cuesta Ridge in the South Fiord study area more likely exposes the Walker Island Member rather than older Paterson Island Member, but a more robust sedimintological and stratigraphic study needs to be undertaken in a future study. 


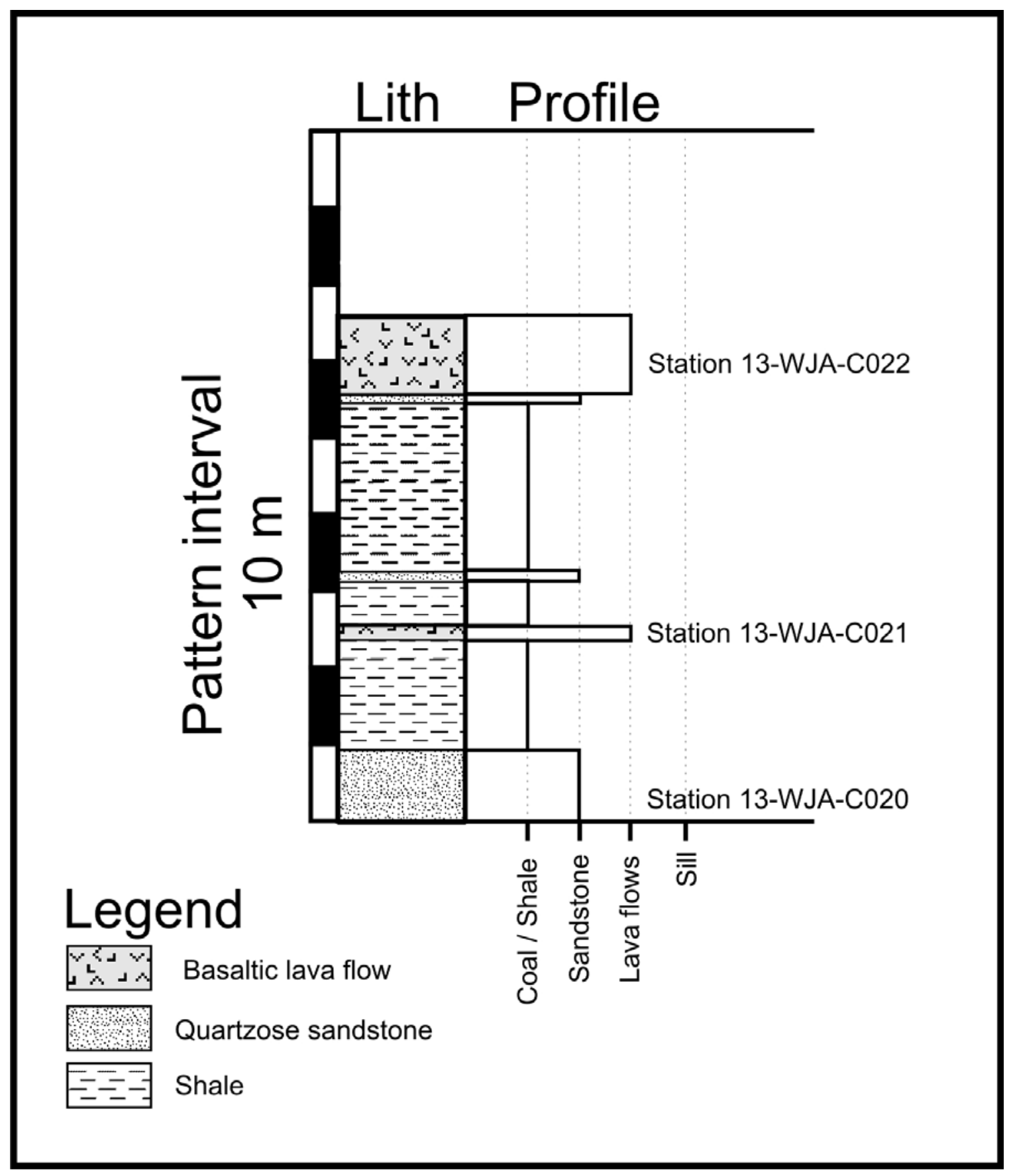

Figure 2.15: Measured stratigraphic section of Cuesta Ridge showing lithology types, outcrop profile and sample stations comprising the Cuesta Ridge section.

The presence of a well-exposed succession of sedimentary rocks and lava flows within the Cuesta Ridge locality (Figs. 2.14) permits a general interpretation of the 
sedimentary and eruption setting for those lavas. The presence of shales along with sandstone interbeds (Fig. 2.14) along with the lack of pillow structures and palagonite within the exposed mafic lava flows leads to my interpretation that these flows are subareal lavas erupted within a broad, low-lying, tidally-influenced plain that was intermittently submerged (deposition of shales) as relative sea level fluctuated over the time of deposition. This interpretation is broadly consistent with the interpretation of Tullius et al. (2014) that the Walker Island Member, where exposed on northern Ellef Ringnes Island and along the Sverdrup Basin depositional axis through the South Fiord region, records a succession of marginal marine and fluvial deposits and regression of the shoreline. Further work on this area as well as the peninsula west of the South Fiord Diapir should seek to (a) determine and clarify the distribution of the Paterson Island and Walker Island Members by tracing the extent of the intervening shale-dominant Rondon Member.

\subsection{MAPPING}

The relationships between intrusive bodies and their host sedimentary rocks within the foot traverse area west of the East Fiord South Diapir are comparatively difficult to diagnose when compared with the dykes and sills in the peninsulas west and south of the South Fiord Diapir (Figs. $2.6 \& 2.7$ ). This is principally due to the high topographic relief owing to an intruding diapir of evaporite (East Fiord South Diapir) that, in concert with permafrost, promotes physical weathering of rock producing extensive aprons of talus that conceal the underlying bedrock (Figs. 2.16A \& B). Therefore within the foot traverse area, it is difficult to determine the thicknesses of 
mafic intrusions. Where mafic rock crop out, it typically manifests as localized sets of remnant columnar cooling joints measuring 10s of $\mathrm{m}$ in lateral extent (e.g Fig. 2.16B \&C) that typically cap the local ridges. In terms of the intrusions, as outcrop quality was generally poor due to talus aprons in the vicinity of the East Fiord Diapir South, it became obvious that certain criteria needed to be established in order to discriminate between intrusions that were dykes or sills so that the geometry and internal structure of intrusive networks may be characterized. In many cases, igneous rocks that are in-situ and that exist as outcrop are characterized by small sets of columnar jointing tops that are oriented perpendicular to the cooling fronts. In regions free from substantial tectonic influences such as the peninsula west of the South Fiord Diapir, sills are characterized by columnar jointing that are oriented sub-vertically (as would be expected, see Fig. 2.7) whereas the orientation of columns in dykes are sub-horizontal.

A main outcome of this field / remote sensing study is that a concentration of tabular intrusions are present immediately west of East Fiord South Diapir which previous air photo-based mapping either missed (Thorsteinsson and Tozer, 1971) or simplified greatly (Jackson and Harrison, 2010). These include approximately seven sills, one dyke and two lava flows within the foot traverse area (Fig. 2.17) along with dykes and sills in the peninsula SW of the foot traverse area. Table 2.2 itemizes mafic igneous bodies in the South Fiord area that were sampled. The proximity of these lava exposures with the intrusive bodies leads to the hypothesis that the foot traverse area exposes a connected volcanic-intrusive complex similar to that mapped on Axel Heiberg Island by Williamson et al. (2016). Subsequent chapters in this thesis will further explore this idea 
of a link between the intrusions and the volcanics based on geochemical and age determination analyses.

Since much of the foot traverse area is situated west of the East Fiord Anticline axis that is cored by the East Fiord Diapir, sedimentary beds dip west (Jackson and Harrison, 2010). On the basis of field reconnaissance mapping, the west-dipping sedimentary sequence is observed at the Cuesta Ridge section. Therefore, if columnar joint tops dip west -parallel to the stratigraphic sequence -- then the structure is a sill. Conversely, if the upper surface of columnar joint sets dip east towards the diapir then the intrusion is a dyke. An interpretative cartoon cross-section resulting from applying the criteria outlined above is shown in Figure 2.18. The result of this mapping within the field traverse area exposes a region of mafic intrusions (both sills and dykes) along with two lava flows not previously mapped at this level of detail and of similar style to other intrusive volcanic complexes which contain sills and dykes of the HALIP documented elsewhere on Axel Heiberg Island (Williamson et al., 2016; Saumur et al., 2016).

Figure 2.16 (Next 2 pages): Three photographs showing perspectives of a field site in the foot traverse region of the study area. Note extensive apron of talus. (A) Photograph looking north. White dashed arrows mark dip direction of tabular mafic intrusions, the easternmost of which is sill S1 in Table 2.2; (B) Another perspective showing columnar jointing of sill S1 of Table 2.2; (C) Closer perspective of remnant columnar jointing from sill S1 oriented from lower right to upper left. Red and blue stars are co-registration marks situated atop prominent features visible in Fig. 2.16A-B. Distance between points $\mathrm{A}$ and $\mathrm{B}$ is $\sim 80 \mathrm{~m}$ and between points $\mathrm{C}$ and $\mathrm{D}$ is $\sim 200 \mathrm{~m}$ along the ridgeline. 

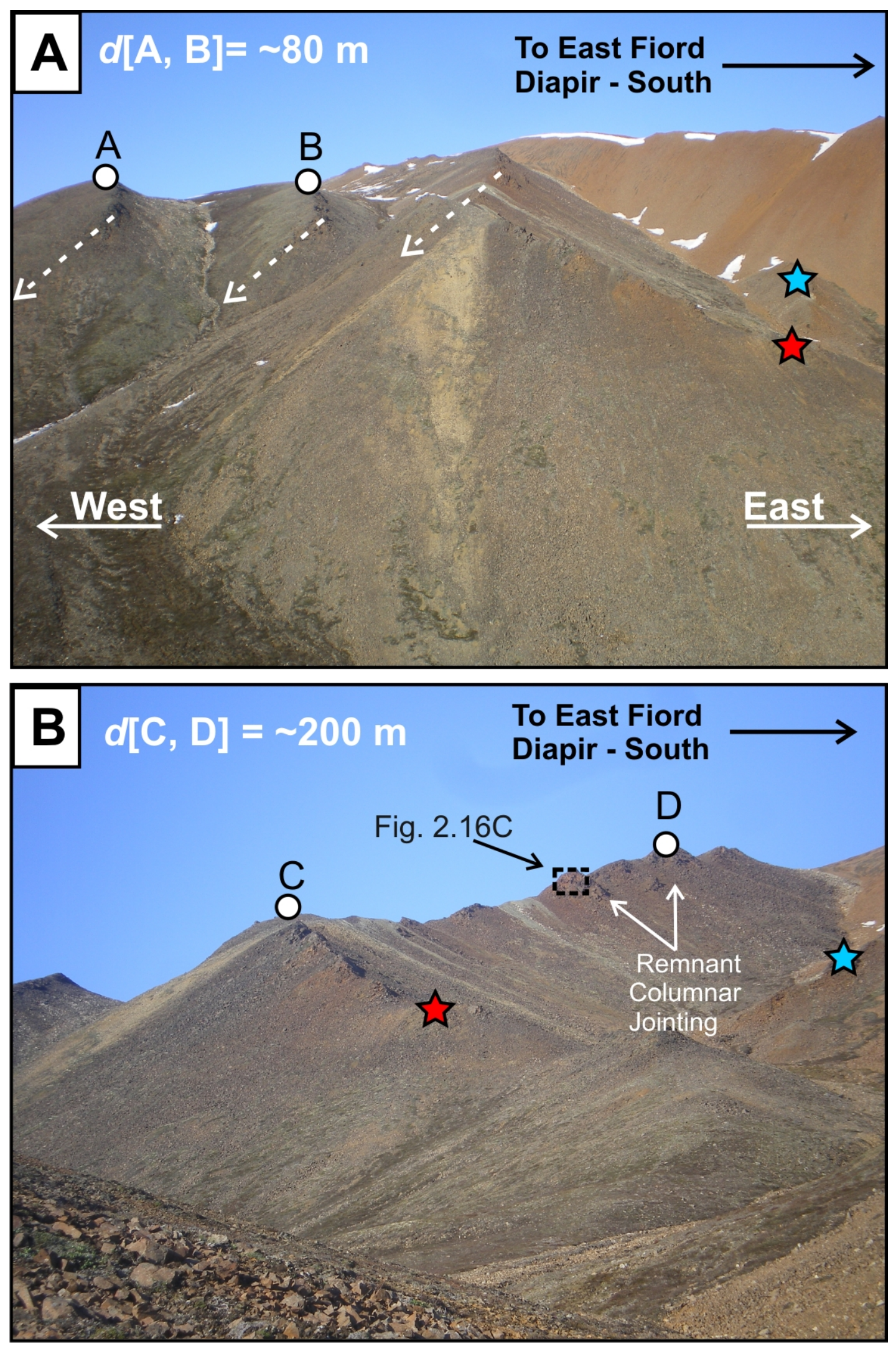


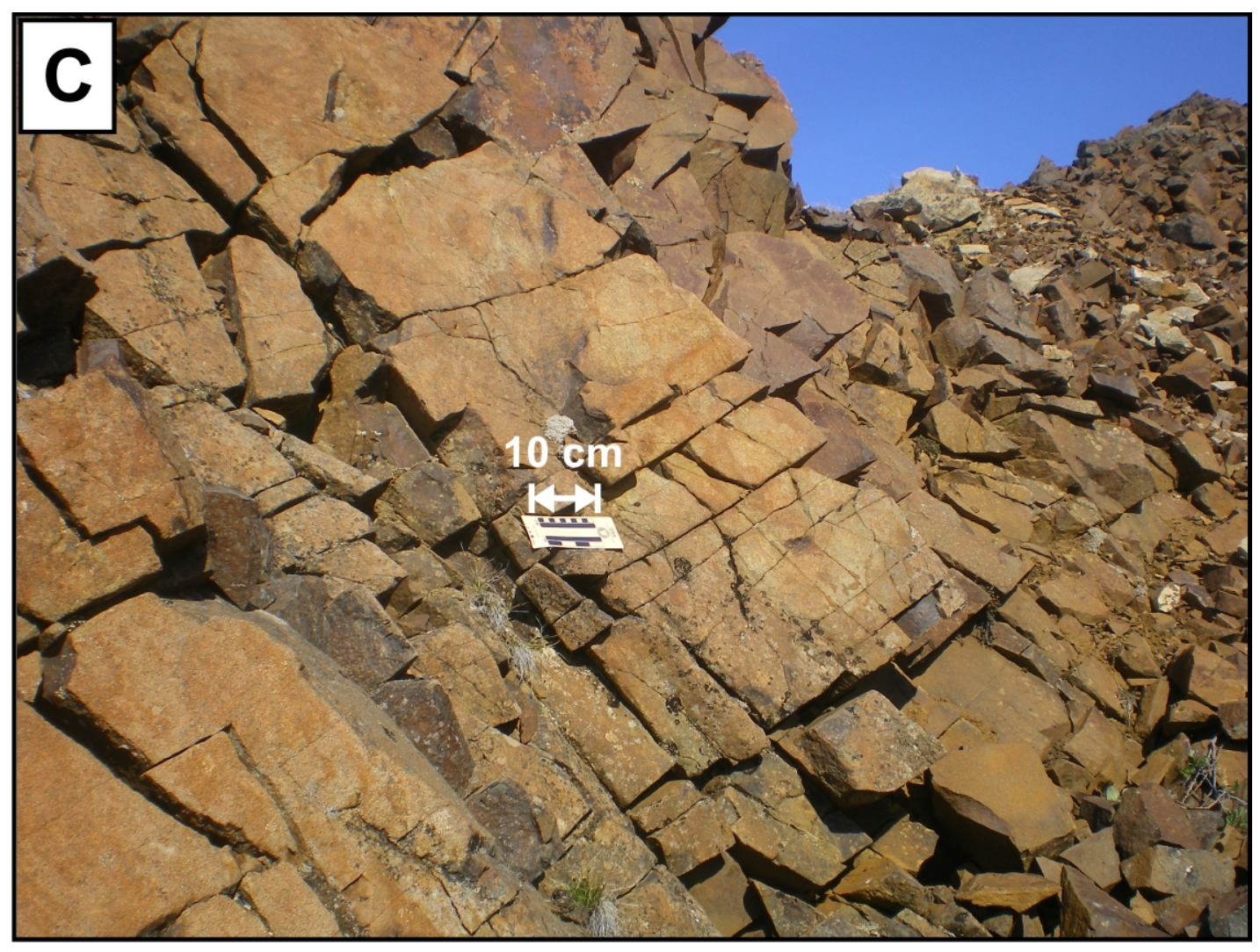




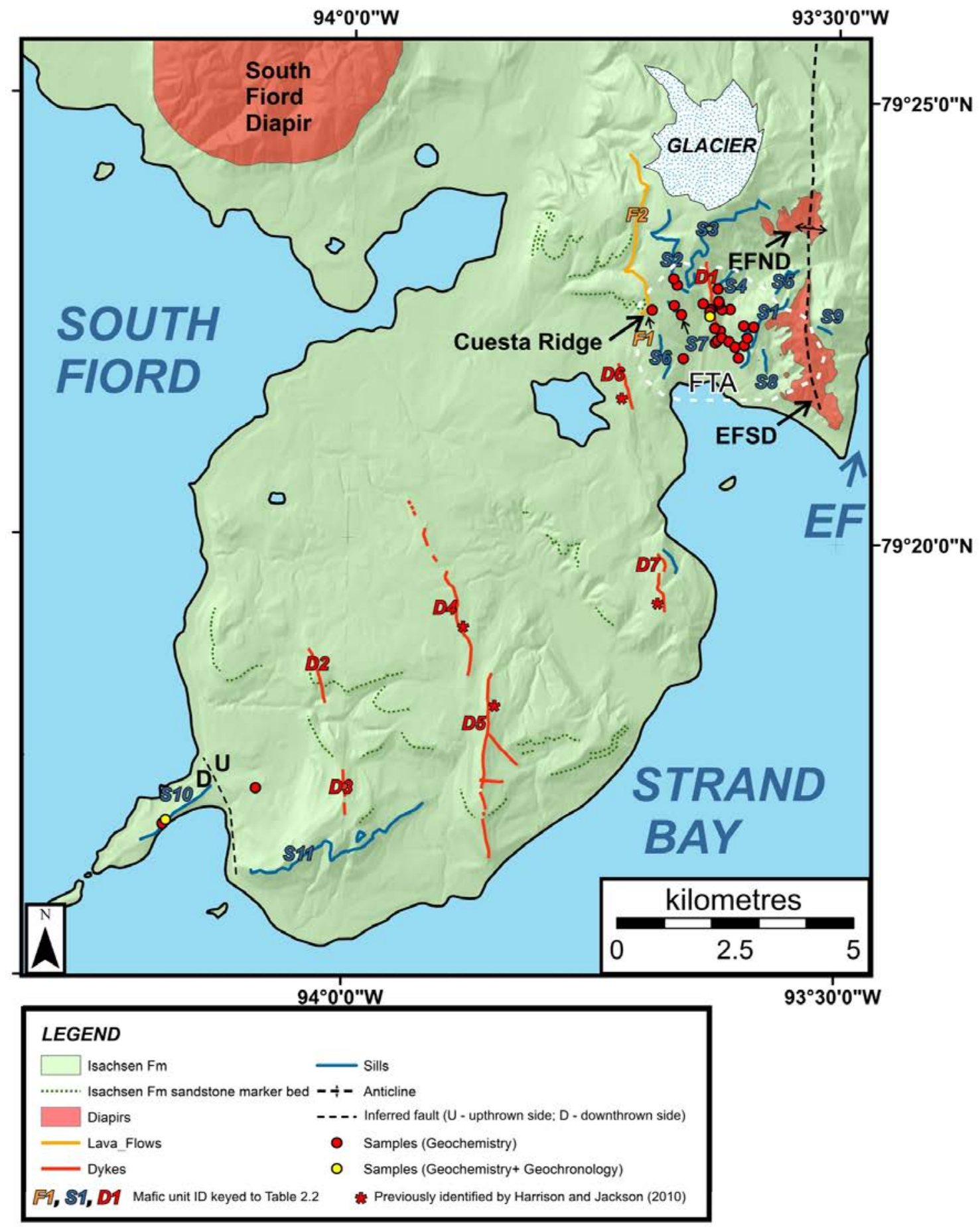

Figure 2.17. Geologic map derived from SPOT-6 imagery draped onto a DEM showing sample locations for geochemistry and geochronology. Key to abbreviation, EF = East Fiord; EFND = East Fiord North Diapir; EFSD = East Fiord South Diapir. FTA $=$ Foot Traverse Area (white dashed enclosure). 


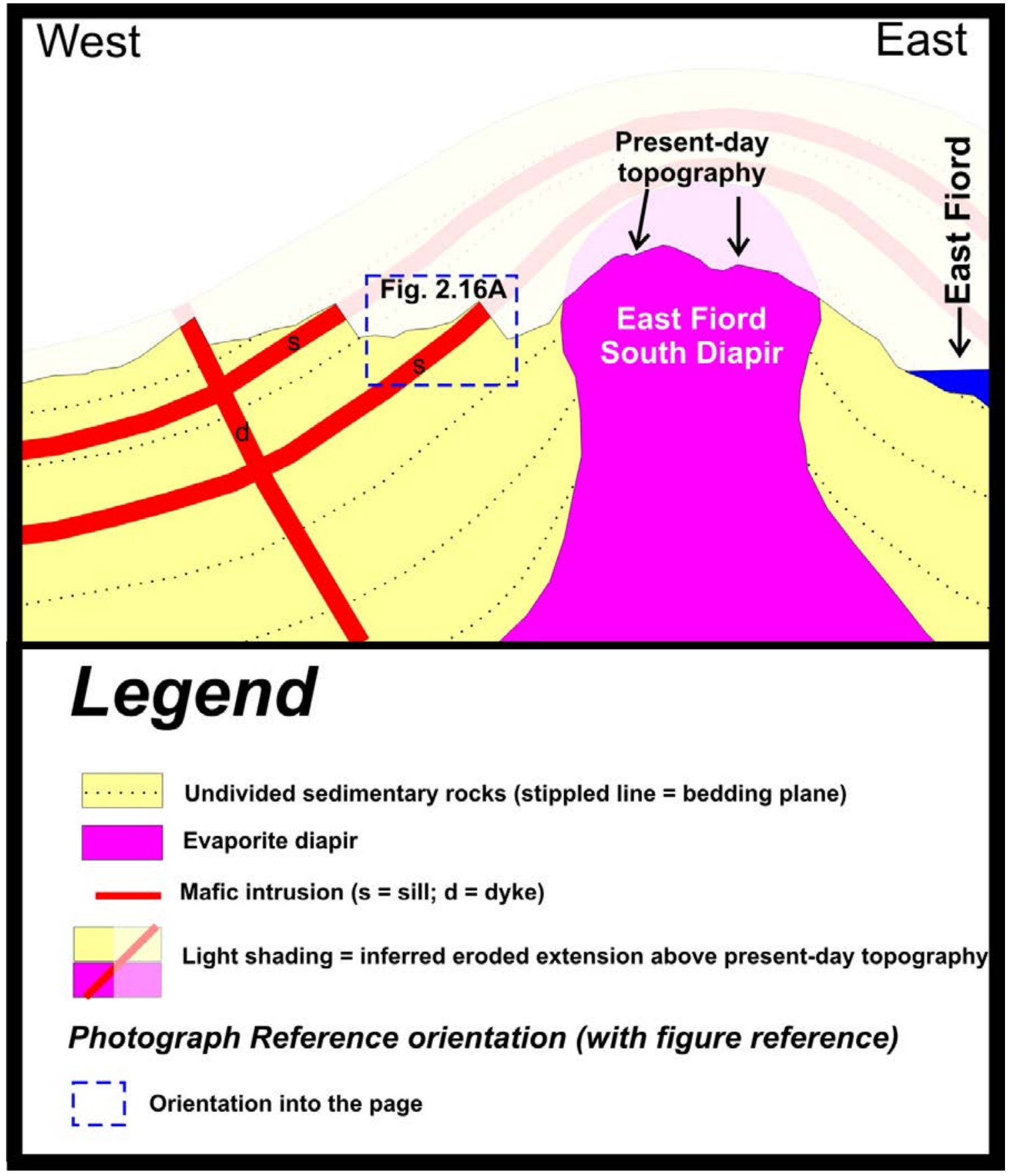

Figure 2.18: Cartoon cross section of the South Fiord Field locality showing relations between sedimentary rocks, mafic intrusions and the East Fiord South Diapir. 


\begin{tabular}{|c|c|c|c|c|c|}
\hline $\begin{array}{l}\text { ID on } \\
\text { Fig. } 2.17\end{array}$ & Type & Thickness & Strike & $\begin{array}{l}\text { Dip } \\
\text { (degrees, dir) }\end{array}$ & Other information \\
\hline D1 & Dyke & $\sim 10 \mathrm{~m}$ & NNW & $45, \mathrm{NE}$ & Thickness estimated, U-Pb age (Ch. 4) \\
\hline D2 & Dyke & $\sim 5 \mathrm{~m}$ & SSE & sub-vertical & $\begin{array}{l}\text { Did not sample. Thickness derived } \\
\text { from estimates on SPOT imagery. }\end{array}$ \\
\hline D3 & Dyke & $\sim 5 \mathrm{~m}$ & SSE & sub-vertical & $\begin{array}{l}\text { Did not sample. Thickness derived } \\
\text { from estimates on SPOT imagery. D3 } \\
\text { continuation of D2? }\end{array}$ \\
\hline D4 & Dyke & $5-10 m$ & SSE & sub-vertical & $\begin{array}{l}\text { Did not visit. Thickness from } \\
\text { estimates on SPOT imagery. }\end{array}$ \\
\hline D5 & Dyke & $\sim 10 \mathrm{~m}$ & $\mathrm{~S}$ & sub-vertical & $\begin{array}{l}\text { Did not visit. Thickness from } \\
\text { estimates on SPOT imagery. Possibly } \\
\text { continuation from D4 }\end{array}$ \\
\hline D6 & Dyke & $\sim 5 \mathrm{~m}$ & SSE & sub-vertical & $\begin{array}{l}\text { Did not visit. Thickness from } \\
\text { estimates on SPOT imagery. }\end{array}$ \\
\hline D7 & Dyke & $\sim 10 \mathrm{~m}$ & $\mathrm{~S}$ & sub-vertical & $\begin{array}{l}\text { Did not visit. Thickness from } \\
\text { estimates on SPOT imagery. Possibly } \\
\text { continuation of D6 }\end{array}$ \\
\hline F1 & $\begin{array}{l}\text { Lava } \\
\text { Flow }\end{array}$ & $2 \mathrm{~m}$ & NNW & $25, W$ & Pahoeheoe \\
\hline F2 & $\begin{array}{l}\text { Lava } \\
\text { Flow }\end{array}$ & $10 \mathrm{~m}$ & SSE & $25, W$ & Scoria flow top \\
\hline S1 & Sill & $\sim 5 \mathrm{~m}$ & SW & 45, NW & Shown on Fig. 2.16 B\&C \\
\hline S2 & Sill & $1.8 \mathrm{~m}$ & sW & $\sim 20, W$ & Thickness measured via tape \\
\hline S3 & Sill & $20-30 m$ & sw & $\sim 20, W$ & Thickness estimated from field photo \\
\hline S4 & Sill & $\sim 10 \mathrm{~m}$ & sW & $\sim 15, W$ & diabasic texture \\
\hline S5 & Sill & unmeas & sw & w & \\
\hline s6 & Sill & unmeas & sW & $\sim 20, W$ & \\
\hline S7 & Sill & $10 \mathrm{~m}$ & SE & $\sim 15 \mathrm{SW}$ & Thickness estimated from field photo \\
\hline $\mathrm{s} 8$ & Sill & $<10 \mathrm{~m}$ & sW & w & $\begin{array}{l}\text { Did not visit. Trend estimate from } \\
\text { SPOT imagery. }\end{array}$ \\
\hline S9 & Sill & $<10 \mathrm{~m}$ & NW & NNE & $\begin{array}{l}\text { Did not visit. Trend estimate from } \\
\text { SPOT imagery. }\end{array}$ \\
\hline S10 & Sill & $>50 \mathrm{~m}$ & sW & $\sim 15$, NNW & U-Pb age (Ch. 4) \\
\hline S11 & Sill & $>50 \mathrm{~m}$ & sW & $\sim 15$, NNW & Probably faulted continuation of $\mathrm{S} 10$. \\
\hline
\end{tabular}

\subsection{CONCLUSION}

On the basis of remote sensing mapping used in tandem with targeted groundbased traverse and helicopter support, the South Fiord field area is shown to include 
abundant mafic sills and dykes, some of which appear to have been deformed by the subsequent intrusion of East Fiord South Diapir (Figs $2.17 \&$ 2.18). Sill thickness ranges from $1.8 \mathrm{~m}$ to $50 \mathrm{~m}$ and averages $5-10 \mathrm{~m}$. The sills average approximately $5 \mathrm{~m}$ thick and are concentrated within Isachsen Formation sedimentary units that include quartzose sandstones and shales. The dyke within the foot traverse area (D1) is estimated to be 10 $m$ in thickness and this and the other dykes that bisect the area have an average trend of NNW-SSE. The presence of two lava flows within the Isachsen Formation and their proximity to intrusive bodies provides for a working hypothesis that the lavas, dykes and sills together potentially compose a connected volcanic-intrusive complex. Finally, as the focus of this study was to understand the nature of emplacement of mafic bodies (intrusions vs. lava flow, sill vs. dyke) and their relationship with the Isachsen Formation sedimentary rocks, no visible connection between the lava flows at Cuesta Ridge and the plumbing system exposed therein are observed. This hypothesis can be tested by evaluating geochemical similarities and differences between South Fiord intrusive bodies and lava flows (Chapter 3) and through U-Pb geochronology (Chapter 4). As the foottraverse area immediately west of East Fiord South Diapir is heavily mantled in talus, it remains unclear how any faulting (if there was indeed faulting) may have affected the distribution of mafic intrusions and the geometry of sedimentary rocks. Based on firstorder stratigraphic work (Figs. $2.14 \& 2.15$ ), the sedimentary rocks comprising the Cuesta ridge section are part of a marginal marine facies that, when combined with the presence of subaerial lavas, suggest that these Lower Cretaceous lavas erupted over a broad, low-lying plain proximal to the paleo-coastline. 


\subsection{CHAPTER REFERENCES}

Behnia, P., Harris, J.R., Rainbird, R.H., Williamson, M.C., and Sheshpari, M., 2012, Remote predictive mapping of bedrock geology using image classification of Landsat and SPOT data, western Minto Inlier, Victoria Island , Northwest

Territories , Canada: International Jornal of Remote Sensing, v. 33, no. 21, p. 37-41.

Buchan, K.L., and Ernst, R.E., 2006, Giant dyke swarms and the reconstruction of the Canadian Arctic islands , Greenland , Svalbard and Franz Josef Land, in Hanski, E., Mertanen, S., Ramo, T., and Vuollo, J. eds., Dyke Swarms - Time Markers of Crustal Evolution, Taylor \& Francis, p. 27-48.

Dibner, V.D., 1998, The geology of Franz Josef Land - an introduction, in Solheim, A., Musatov, E., and Heintz, N. eds., Geological Aspects of Franz Josef Land and the Northerenmost Barents Sea, Oslo, p. 10-17.

Døssing, A., Jackson, H.R., Matzka, J., Einarsson, I., Rasmussen, T.M., Olesen, A. V, and Brozena, J.M., 2013, On the origin of the Amerasia Basin and the High Arctic Large Igneous Province -- Results of new aeromagnetic data: Earth and Planetary Science Letters, v. 363, p. 219-230.

Drachev, S., and Saunders, A., 2006, The early Cretaceous Arctic LIP: its geodynamic setting and implications for Canada Basin opening, in Scott, R.A. and Thurston, D.K. eds., Proceedings of the Fourth International Conference on Arctic Margins, Anchorage, USA.

Embry, A.F., and Beauchamp, B., 2008, Chapter 13: Sverdrup Basin, in Miall, A.D. ed., Sedimentary Basins of the World: Volume 5, p. 451-471.

Embry, A.F., and Osadetz, K.G., 1988, Stratigraphy and tectonic significance of 
Cretaceous volcanism in the Queen Elizabeth Islands, Canadian Arctic Archipelago: Canadian Journal of Earth Sciences, v. 25, p. 1209-1219.

Evenchick, C.A., Davis, W.J., Bédard, J.H., Hayward, N., and Friedman, R.M., 2015, Evidence for protracted High Arctic large igneous province magmatism in the central Sverdrup Basin from stratigraphy, geochronology, and paleodepths of saucer-shaped sills: Geological Society of America Bulletin, p. B31190.1, doi: 10.1130/B31190.1.

Hadlari, T., Midwinter, D., Galloway, J.M., Dewing, K., and Durbano, A.M., 2016, Mesozoic rift to post-rift tectonostratigraphy of the Sverdrup Basin, Canadian Arctic: Marine and Petroleum Geology, v. 76, p. 148-158, doi:

10.1016/j.marpetgeo.2016.05.008.

Harris, J.R., Grunsky, E.C., He, J., Gorodetzky, D., and Brown, N., 2012, A robust, cross-validation classification method (RCM) for improved mapping accuracy and confidence metrics: Canadian Journal of Remote Sensing, v. 38, no. 1, p. 69-90, doi: $10.5589 / \mathrm{m} 12-013$

Jackson, M.P.A., and Harrison, J.C., 2006, An allochthonous salt canopy on Axel Heiberg Island, Sverdrup Basin, Arctic Canada: Geology, v. 34, no. 12, p. 10451048.

Jackson, M.P., and Harrison, J.C., 2010, Geology, Strand Fiord-Expedition Fiord Area, Western Axel Heiberg Island, Nunavut.: Geological Survey of Canada, Map 2157A, scale 1:100,000.

Kingsbury, C.G., Ernst, R.E., Cousens, B.L., and Williamson, M.-C., 2016, The High Arctic LIP in Canada: Trace element and Sm-Nd Isotopic evidence for the role of 
mantle heterogeneity and crustal assimilation: Norwegian Journal of Geology, v. 96, no. 2, p. 13-33.

Kingsbury, C.G., Williamson, M.-C., Day, S.J., and McNeil, R.J., 2014, The 2013

Isachsen expedition to Axel Heiberg Island, Nunavut, Canada: a field report:

Geological Survey of Canada, Open File 7539, 2014; 6 pages (1 sheet), doi:10.4095/293842,.

Maher, H.D., 2001, Manifestations of the Cretaceous High Arctic Large Igneous

Province in Svalbard: The Journal of Geology, v. 109, no. 1, p. 91-104, doi:

$10.1086 / 317960$

McNeil, R.J., Day, S.J.A., and Williamson, M.-C., 2014, Stream sediment and water geochemical study, Axel Heiber Island, Nunavut, Canada, in Williamson, M.-C. ed., Environmental and Economic Significance of Gossans, Geological Survey of Canada Open FIle 7718, p. 85-96.

Nassichuk, W.W., and Davies, G.R., 1980, Stratigraphy and sedimentation of the Otto Fiord formation - a major Mississippian-Pennsylvanian evaporite of subaqueous origin in the Canadian Arctic Archipelago, in Irish, E.J.W. ed., Geological Survey of Canada Bulletin 286, Ottawa, ON, p. 87.

National Atmospheric and Space Administration, 2004, ASTER Instrument Characteristics: http://asterweb.jpl.nasa.gov/characteristics.asp (accessed 13 May 2016).

Nejbert, K., Krajewski, K.P., Dubinska, E., and Pécskay, Z., 2011, Dolerites of Svalbard, north-west Barents Sea Shelf: age, tectonic setting and significance for geotectonic interpretation of the High-Arctic Large Igneous Province: Polar Research, v. 30, no. 
0, p. 1-24, doi: 10.3402/polar.v30i0.7306.

Oakey, G.N., and Saltus, R.W., 2016, Geophysical analysis of the Alpha-Mendeleev ridge complex: Characterization of the High Arctic Large Igneous Province: Tectonophysics, doi: 10.1016/j.tecto.2016.08.005.

Patchett, P.J., Embry, A.F., Ross, G.M., Beauchamp, B., Harrison, J.C., Mayr, U., Isachsen, C.E., Rosenberg, E.J., and Spence, G.O., 2004, Sedimentary Cover of the Canadian Shield through Mesozoic Time Reflected by Nd Isotopic and Geochemical Results for the Sverdrup Basin, Arctic Canada: The Journal of Geology, v. 112, no. 1, p. 39-57.

Patchett, P.J., Roth, M.A., Canale, B.S., de Freitas, T.A., Harrison, J.C., Embry, A.F., and Ross, G.M., 1999, Nd isotopes, geochemistry, and constraints on sources of sediments in the Franklinian mobile belt, Arctic Canada: Geological Society of America Bulletin, v. 111, no. 4, p. 578-589, doi: 10.1130/00167606(1999)111<0578:NIGACO>2.3.CO;2.

Percival, J.B., Williamson, M.-C., McNeil, R.J., Day, S.J.A., and Harris, J.R., 2014, Morphology of gossans in the Canadian Arctic Islands, in Williamson, M.-C. ed., Environmental and Economic Significance of Gossans, Geological Survey of Canada Open FIle 7718, p. 58-73.

Petrov, O., Morozov, A., Shokalsky, S., Kashubin, S., Artemieva, I.M., Sobolev, N., Petrov, E., Ernst, R.E., Sergeev, S., and Smelror, M., 2016, Crustal structure and tectonic model of the Arctic region: Earth-Science Reviews, v. 154, p. 29-71, doi: 10.1016/j.earscirev.2015.11.013.

Polteau, S., Hendriks, B.W.H., Planke, S., Ganerød, M., Corfu, F., Faleide, J.I., 
Midtkandal, I., Svensen, H.S., and Myklebust, R., 2016, The Early Cretaceous

Barents Sea Sill Complex: Distribution, 40Ar/39Ar geochronology, and implications for carbon gas formation: Palaeogeography, Palaeoclimatology, Palaeoecology, v. 441, p. 83-95, doi: 10.1016/j.palaeo.2015.07.007.

Ricketts, B., Osadetz, K.G., and Embry, A.F., 1985, Volcanic style in the Strand Fiord Formation (Upper Cretaceous), Axel Heiberg Island, Canadian Arctic Archipelago: Polar Research, v. 3, no. 1, p. 107-122, doi: 10.1111/j.1751-8369.1985.tb00497.x. Satelite Imaging Corporation, 2005, SPOT-6 Satelite Sensor: http://www.satimagingcorp.com/satellite-sensors/spot-6/ (Accessed 15 July 2016). Saumur, B.-M., Dewing, K., and Williamson, M.-C., 2016, Architecture of the Canadian portion of the High Arctic Large Igneous Province and implications for magmatic Ni-Cu potential: Canadian Journal of Earth Sciences, v. 53, p. 528-542.

Senger, K., Tveranger, J., Ogata, K., Braathen, A., and Planke, S., 2014, Late Mesozoic magmatism in Svalbard: A review: Earth-Science Reviews, v. 139, p. 123-144, doi: 10.1016/j.earscirev.2014.09.002.

Tessensohn, F., and Piepjohn, K., 2000, Eocene compressive deformation in Arctic Canada, North Greenland and Svalbard and its plate tectonic causes: Polarforschung, v. 68 , no. $1-3$, p. $121-124$.

Thorsteinsson, R., and Tozer, E.T., 1971, Geology, Middle Fiord, District of Franklin: Geological Survey of Canada, Map 1299A, scale 1:250,000.

Tullius, D.N., Leier, A.L., Galloway, J.M., Embry, A.F., and Pedersen, P.K., 2014, Sedimentology and stratigraphy of the Lower Cretaceous Isachsen Formation: Ellef Ringnes Island, Sverdrup Basin, Canadian Arctic Archipelago: Marine and 
Petroleum Geology, v. 57, p. 135-151, doi: 10.1016/j.marpetgeo.2014.05.018.

United States Geological Survey, 2015, Frequently Asked Questions about the Landsat Missions: http://landsat.usgs.gov/best_spectral_bands_to_use.php (Accessed 30 June 2016).

Wilford, J., and Creasey, J., 2002, Landsat thematic mapper, in Papp, E. ed., Geophysical and Remote Sensing Methods for Regolith Exploration, CRCLEME Open File Report 144, p. 6-12.

Williamson, M.-C., 1988, The Cretaceous igneous province of the Sverdrup Basin, Canadian Arctic: Field relations and petrochemical studies: Ph.D. thesis, Dalhousie University, Halifax, Nova Scotia, 417 p.

Williamson, M.-C., Lyon, S.A., Budkewitsch, P., and Zentilli, M., 2006, Evaporite deposits in volcanic fields as potential targets in the search for extraterrestrial life: Examples from Axel Heiberg Island, Canadian Arctic Archipelago, in Program, Exploration Canada, Canadian Space Agency, p. 14 (Poster).

Williamson, M.-C., McNeil, R.J., Day, S.J.A., McCurdy, M.W., Rainbird, R.H., and Grunsky, E.C., 2014, Environmental impact of gossans revealed by orientation surveys for base metals in the Canadian Arctic Islands, in Williamson, M.-C. ed., Environmental and Economic Significance of Gossans, Geological Survey of Canada Open FIle 7718, p. 74-84.

Williamson, M.-C., Saumur, B.-M., and Evenchick, C.A., 2016, HALIP volcanicintrusive complexes, Axel Heiberg Island, Nunavut, in Williamson, M.-C. ed., Report of Activities for High Arctic Large Igneous Province (HALIP)-GEM 2 Western Arctic Region Project: Bedrock Mapping and Mineral Exploration: 
Geological Survey of Canada Open File 7950, p. 14-26, doi: 10.4095/297487. 


\section{Chapter 3:}

\section{Major, trace element and Sm-Nd isotopic evidence for the role of mantle heterogeneity and crustal assimilation in HALIP from South Fiord, Geodetic Hills and Camp Five Creek, Axel Heiberg Island}

\section{Note: This chapter is mostly based on the publication (see preface):}

Kingsbury, C.G., Ernst, R.E., Cousens, B.L., and Williamson, M.-C., 2016, The High Arctic LIP in Canada: Trace element and Sm-Nd isotopic evidence for the role of mantle heterogeneity and crustal assimilation: Norwegian Journal of Geology, v. 96, no. 2, p. 13-33.

\subsection{INTRODUCTION}

The Mesozoic geodynamic evolution and the timing of tectonic events leading to the present-day configuration of the Arctic Ocean and its margins represent one of the last major ocean basin-scale puzzles to be understood in elucidating post-Pangaea rifting events. The Circum-Arctic landmasses of Canada, Norway and western Siberia (Russia) along with offshore regions (for example, the Alpha - Mendeleev Ridge) are endowed with extensive mafic dyke swarms, sill provinces and lavas of Cretaceous age that have historically been amalgamated into, and been understood as fragments of, a oncecontiguous "High Arctic large igneous province" (HALIP) (Fig. 3.1; Drachev and Saunders, 2006; Maher, 2001).

Giant mafic dyke swarms are a major constituent of the HALIP, largely in Canada but significant tabular intrusions also exist on Svalbard (Nejbert et al., 2011; Senger et al., 2014) and Franz Josef Land (Amundsen et al., 1998; Bailey and Brooks, 1988 and references therein). In the Canadian Arctic islands, the Queen Elizabeth Islands dykes form a radiating swarm of $\sim 900 \mathrm{~km}$ in maximum length that focusses just off the northern 
Ellesmere Island coast (Fig. 3.1). These dyke swarms, along with evidence of Cretaceous domal uplift centered north of Svalbard (Maher, 2001), suggest that the HALIP was fed by a mantle plume head centred north of Ellesmere Island near the Alpha Ridge (e.g.

Ernst and Buchan, 2003; also Maher, 2001).

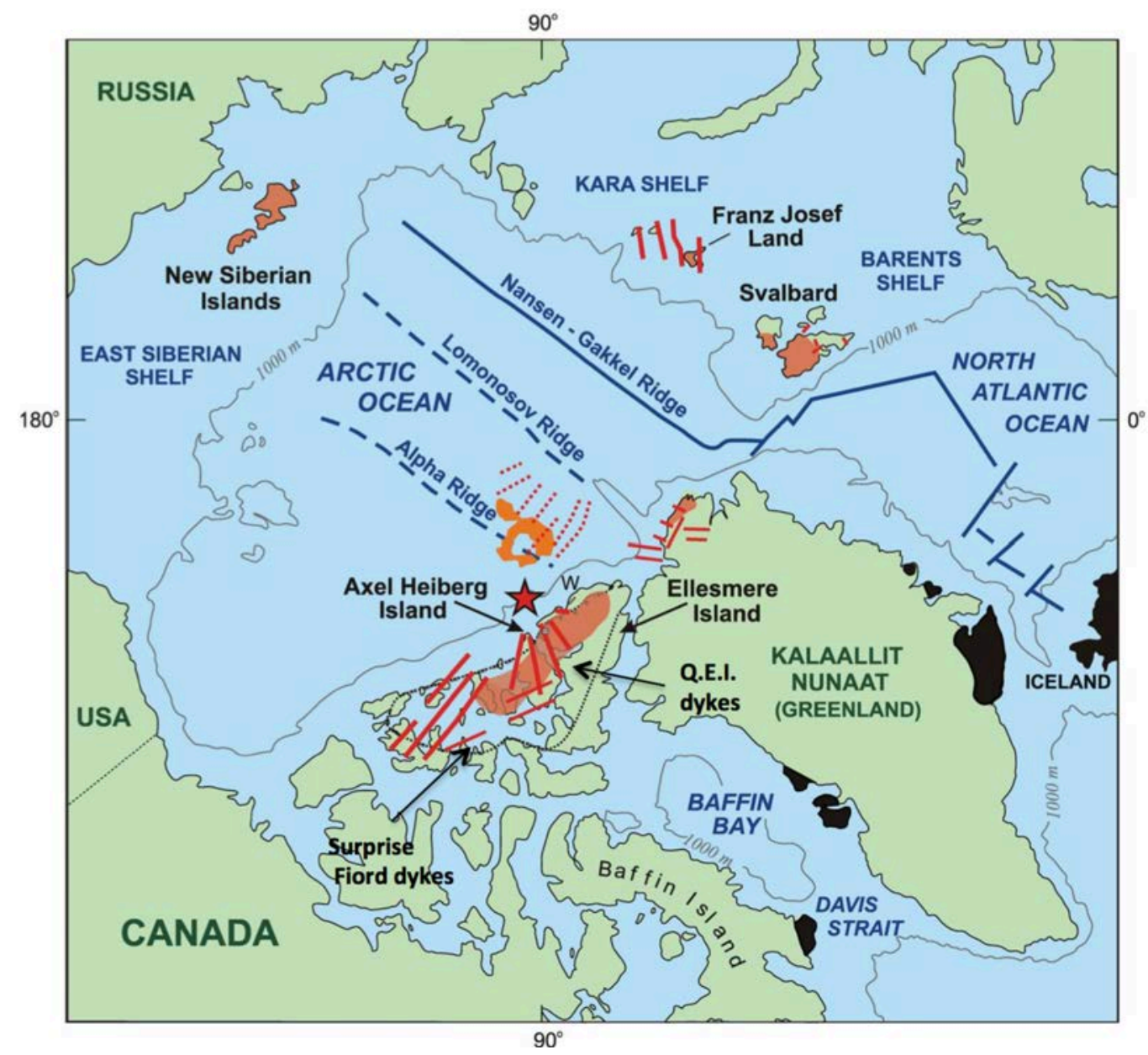

Figure 3.1: Pan-Arctic map showing distribution of dykes (red lines) as well as lavas and sills (orange-red shading) ascribed to the HALIP (Jowitt et al., 2014) exposed on land. Red star denotes probable location of mantle plume from Buchan and Ernst (2006). Black shading denotes the unrelated and younger North Atlantic Igneous Province. Dyke swarm distribution from Buchan and Ernst (2006). Q.E.I = Queen Elizabeth Islands. The orange circular anomaly along with stippled red lines in the Arctic Ocean, denoting aeromagnetic anomalies, are from (Døssing et al., 2013). "W" on northern Ellesmere Island represents the location of the Wootton igneous complex, a part of the HALIP and which is discussed in the text. Black irregular thin stippled line on the Canadian side outlines the Sverdrup Basin. 
The Canadian component of the HALIP is associated with the Cretaceous tectonic rejuvenation of the Sverdrup basin, a long-lived epicontinental sedimentary basin that developed between the Carboniferous and the end of the Cretaceous (Fig. 3.2; Embry, 2011; Embry and Osadetz, 1988). Whereas much of the Sverdrup Basin evolution was by way of passive subsidence coupled with periods of uplift, this passive state of development was punctuated by two major active episodes: an initial active rifting which marked initial basin formation in the Carboniferous and a second rejuvenated period of subsidence during the interval between the Early Cretaceous and Cenomanian (Embry and Beauchamp, 2008). Mounting evidence from elsewhere on the globe strongly suggests that in many cases, but not all, LIPs herald major breakup events, such as the 201 Ma Central Atlantic Magmatic Province, the 135 Ma Parana - Etendeka LIP and the 60 Ma North Atlantic Igneous Province for the staged rifting of the central, southern and northern Atlantic Ocean, respectively (White and McKenzie, 1989; Milner et al., 1995; Peate, 1997; Courtillot et al, 1999; Marzoli, 1999; Smallwood and White, 2002; Ernst, 2014).

On the basis of previous stratigraphic work (Embry and Osadetz, 1988), four Cretaceous HALIP volcanic cycles occurred within Canada (Fig. 3.3): (1) Paterson Island Member of the Isachsen Formation (Valanginian - early Barremian); (2) Walker Island member of the Isachsen Formation (Late Barremian - Aptian); (3) Strand Fiord Formation (Late Aptian - early Cenomanian); and finally (4) Hansen Point volcanics (late Cenomanian - Maastrichtian), Embry and Osadetz (1988). Cycles 1, 2, 3, and 4 correspond with approximate ages of $130 \mathrm{Ma}, 120 \mathrm{Ma}, 100 \mathrm{Ma}$ and $85 \mathrm{Ma}$ (Embry and Osadetz, 1988; Cohen et al., 2013). The HALIP historically has been divided into two 
chemical suites: a tholeiitic suite from 130 - $80 \mathrm{Ma}$ and younger alkaline suite from 85 $60 \mathrm{Ma}$ (Tegner et al., 2011). In the Canadian component of the HALIP, the tholeiitic suite corresponds with events $1-3$ (Isachsen Formation and the Strand Fiord Formation) whereas the alkaline suite is represented by event 4 (Hansen Point Volcanics) (Williamson, 1988; Embry and Osadetz, 1988; Jowitt et al., 2014).

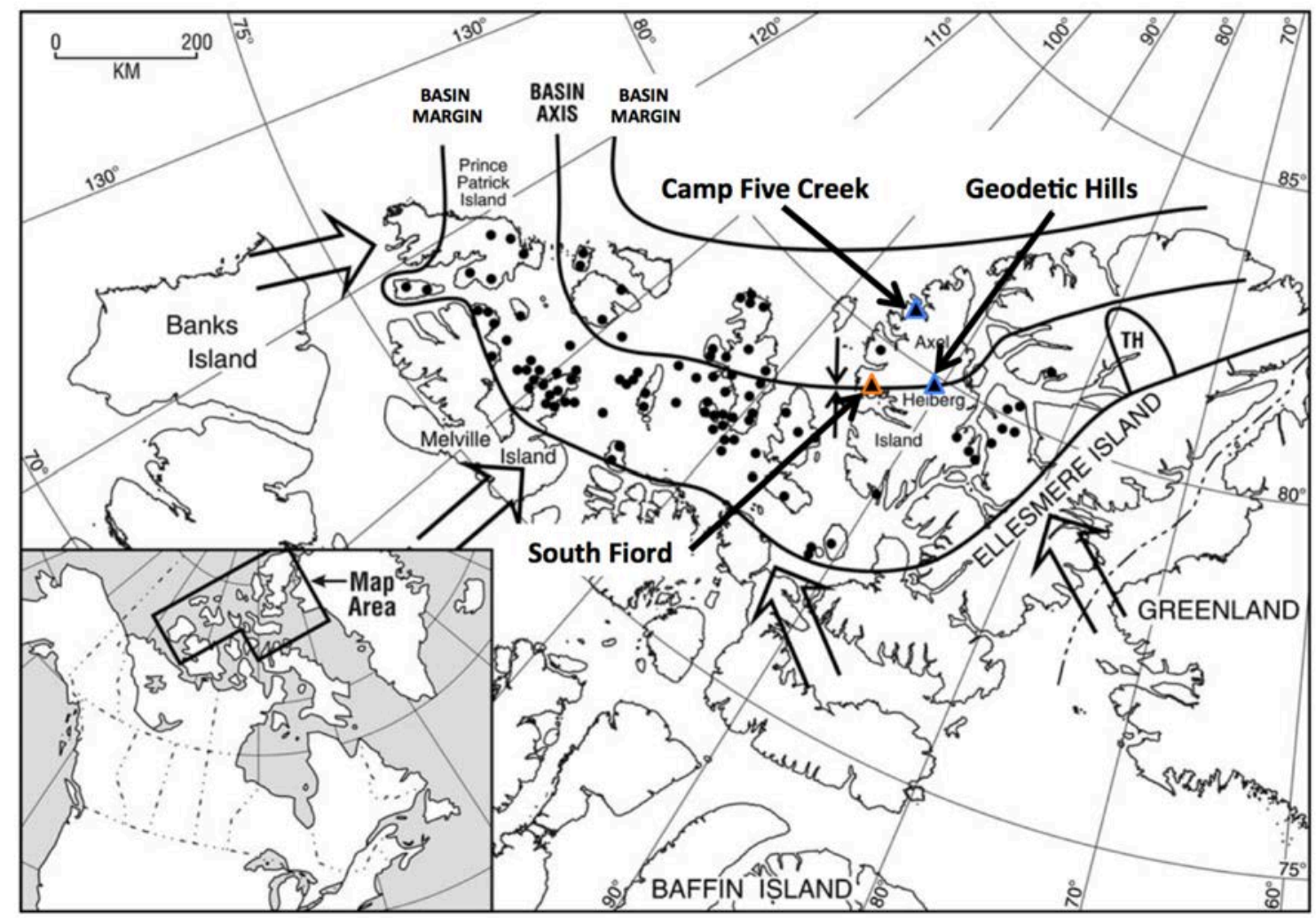

Figure 3.2: Outline map of the Sverdrup Basin showing study sites of South Fiord (intrusives) along with Geodetic Hills and Camp Five Creek for the Isachsen Formation lavas. Outline colours of the triangles keyed to symbol colour used in geochemical plots and Figure 3.3. Black dots represent wells drilled (Embry and Beauchamp, 2008). TH denotes Tanquary High and the large north to northwest pointing arrows south of the basin denote sediment provenance (map modified from Embry and Beauchamp, 2008). 


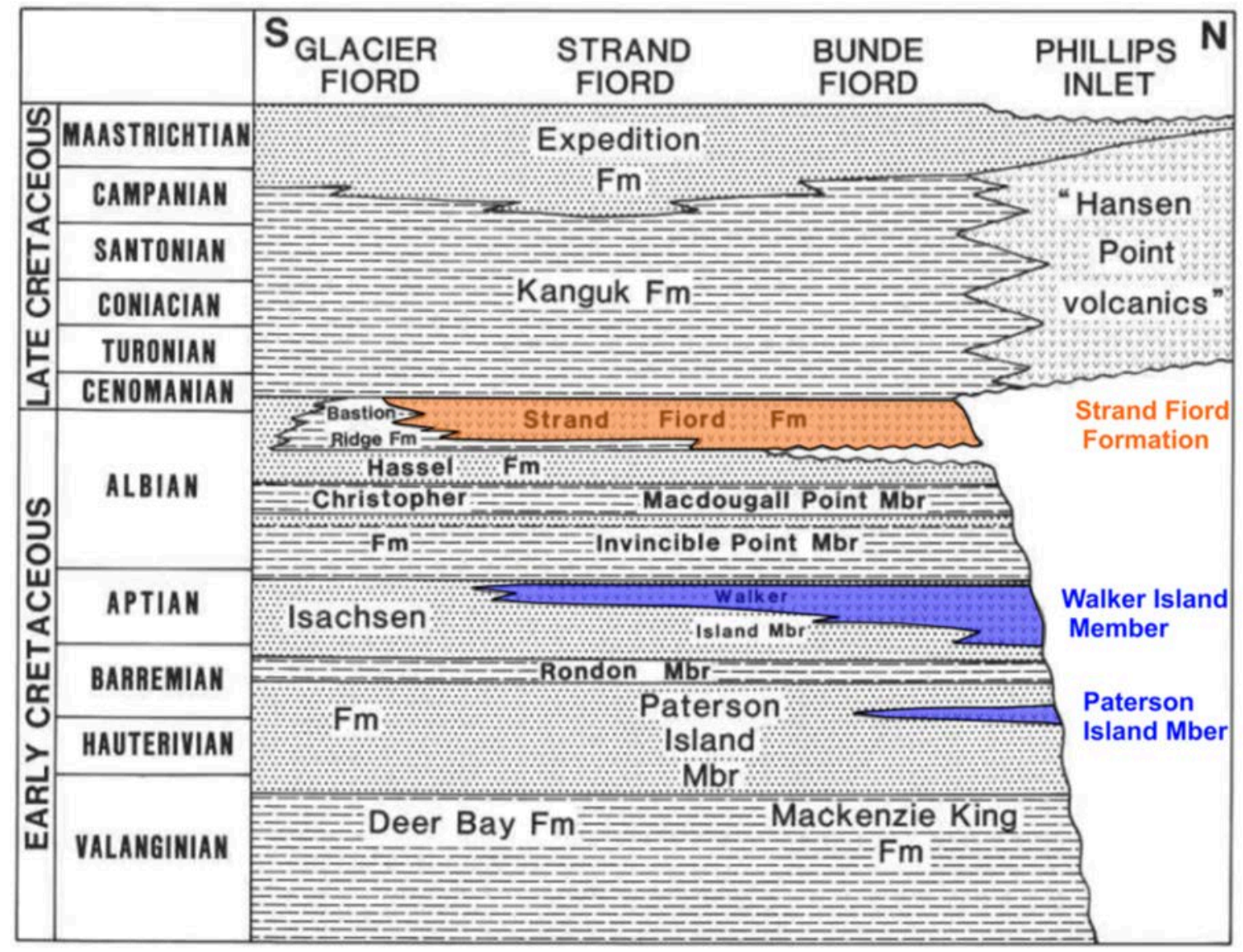

Figure 3.3: Stratigraphic sequence of the Cretaceous component of the Sverdrup basin highlighting the younger Strand Fiord Formation lavas (in orange) and the older Isachsen Formation lavas (in blue). Original diagram from (Embry and Osadetz, 1988). Orange and blue colours of the Strand Fiord Formation and Isachsen Formation lavas (respectively) are used for the geochemical plot symbols in the Results and Discussion sections, Sections 3.3 and 3.4, respectively.

Earlier age studies using the K-Ar and Ar-Ar methods suggested that a pulse of magmatism occurred in the Canadian Arctic from $112 \mathrm{Ma}-152 \mathrm{Ma}$ along with a later pulse associated with the Strand Fiord Formation lavas from $95 \mathrm{Ma}-100 \mathrm{Ma}$

(Villeneuve and Williamson, 2006 and references therein). In Svalbard, K-Ar ages from sills suggest magmatism occurred from $80-125 \mathrm{Ma}$ with a peak at $117 \mathrm{Ma}$ and an Ar-Ar 
age of 120 Ma was recently determined from a sill in Svalbard (Nejbert et al., 2011; Polteau et al., 2016).

A small and growing number of U-Pb ages on tabular doleritic intrusions along with the gabbroic Wootton Igneous Complex (northern Ellesmere Island) are clarifying and constraining ages from earlier K-Ar an Ar-Ar studies and yielding evidence of magmatic activity between 121 -126 Ma and 92 Ma (Evenchick et al., 2014; Evenchick et al., 2015; Estrada and Henjes-Kunst, 2013; Corfu et al., 2013; Trettin and Parrish, 1987). On the Eurasian side of the Arctic (Svalbard, Norway and Franz Josef Land, Russia) U-Pb ages from four diabasic sills (two each from Svalbard Franz Josef Land) along with a bentonite ash layer yield a tight age range from 122 - $126 \mathrm{Ma}$ (Corfu et al., 2013). In Canada, three U-Pb ages from two diabasic sills and a single pyroclastic unit (which might be unrelated to the HALIP) are 120 and $126 \mathrm{Ma}$ (two sills) and $105 \mathrm{Ma}$ (pyroclastic unit), on Ellef Ringnes Island (Evenchick et al., 2014; Evenchick et al., 2015). This collection of $\mathrm{U}-\mathrm{Pb}$ data suggests that magmatism was more protracted in the Canadian side of the Arctic when compared with the age range on the Eurasian side. Specifically, in addition to the 120-125 Ma pulse of magmatism scattered about the Arctic Margins, a younger episode of mafic magmatism ensued approximately $30 \mathrm{Ma}$ later, largely affecting the Canadian side of the Arctic Ocean. Two separate studies on the gabbroic - microgranite Wootton Igneous Complex, located along the extreme northern Ellesmere Island coast, yielded U-Pb ages of 92.0 \pm 1.0 Ma (Trettin and Parrish, 1987) and 92.1 \pm 0.1 Ma (Estrada and Henjes-Kunst, 2013) on the gabbroic component, as well

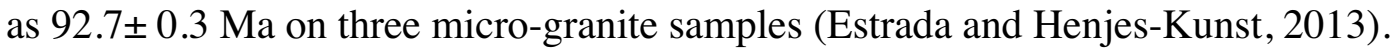


On the basis of trace element and precious metal analysis, the Canadian component of the HALIP was divided into "tholeiitic" (Strand Fiord Formation lavas and intrusions) and "mildly alkaline" (Hassel Formation) groups (Jowitt et al., 2014). Initial Sm-Nd isotopic analyses on the younger volcanic suite (Strand Fiord Formation lavas) and the older volcanic suite (Isachsen Formation lavas) suggests that they were both derived from an upper mantle source (Estrada and Henjes-Kunst, 2004). The tholeiitic rocks may have $\mathrm{Ni}-\mathrm{Cu}-\mathrm{PGE}$ potential owing to trace element evidence of crustal assimilation along with variable precious metal ratios (Jowitt et al., 2014).

One powerful tool that may be used in assessing whether these igneous rocks are petrogenetically related HALIP fragments is $\mathrm{Sm}-\mathrm{Nd}$ isotope geochemistry. In Canada, $\mathrm{Nd}$ isotopic data are available in the literature for four flows from the Early Cretaceous Isachsen Formation Basalts and four lavas from the earliest Late Cretaceous Strand Fiord Formation basalts (Estrada and Henjes-Kunst, 2004). Herein, we present trace-element data along with 20 new Sm-Nd isotopic analyses derived from samples collected from western Axel Heiberg Island in the vicinity of South Fiord during a field expedition in 2013 (Figs. 3.2 \& 3.4) and from previously-collected samples of Isachsen Formation flows at Geodetic Hills, central Axel Heiberg Island and Camp Five Creek, northwestern Axel Heiberg Island (Fig. 3.2; Williamson, 1988; Williamson, unpublished data). These data allow characterization of the geochemistry of mantle sources for the HALIP, as well as post-melting processes which may have affected the initial chemistry of these melts. Did primary magmas interact with specific lithospheric mantle or crustal material, and if 

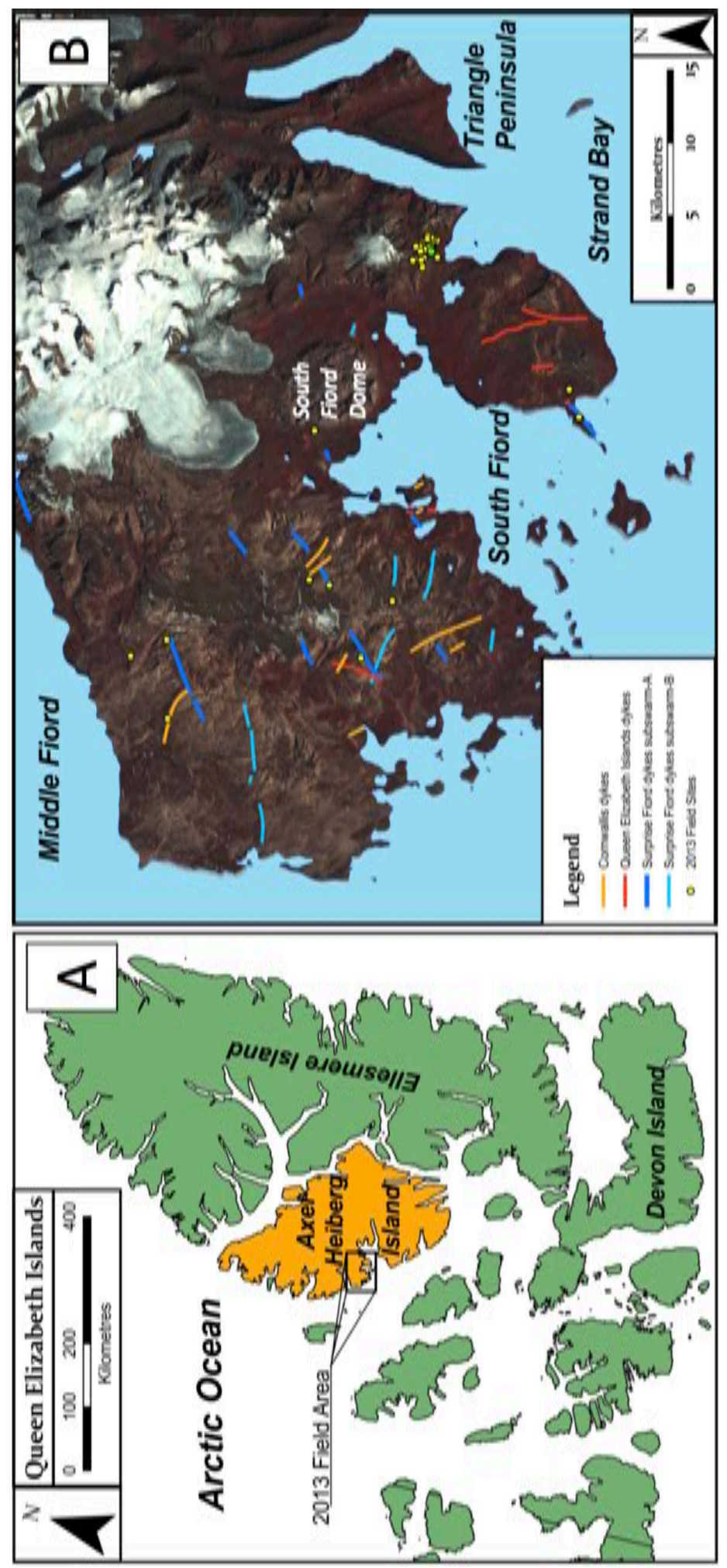

Figure 3.4: (a) Map showing Axel Heiberg Island (orange) and the location of the 2013 South Fiord field area. (b) False-colour Landsat-7 satellite imagery of the South Fiord area showing locations of field sites (this study) and previously-mapped representative dykes of HALIP swarms (Buchan and Ernst, 2013). See also Figure 2.17 in Chapter 2 for more detailed mapping and sample locations. 
crustal interaction did occur was it with basement rocks of continental crust (i.e., cratonic), or with the sedimentary packages that overlie the cratonic basement? Finally, since volcanism associated with the younger Strand Fiord Formation and older Isachsen Formation lavas must be fed through a network of dominantly tabular intrusions, we aim to determine whether the tabular intrusions in the vicinity of South Fiord (described below) were feeders of the Strand Fiord Formation and/or the Isachsen Formation lavas.

\subsection{METHODS}

\subsubsection{Field and sampling methods}

Approximately 40 samples were collected from sills and dykes of the South Fiord area with thickness typically less than $10 \mathrm{~m}$, as well as from one lava flow of the Isachsen Formation (see Table 2.2 in Chapter 2; Kingsbury et al., 2014). However, owing to such factors as deformation due to intruding evaporitic diapirs (e.g. South Fiord Dome; Fig. 3.4) as well as Paleocene - Eocene Eurekan orogeny deformation (Embry and Beauchamp, 2008), coupled with cyclic freeze-thaw processes, much of the topography consists of ridges mantled with talus (Chapter 2). Thus, it was commonly a challenge to determine whether intrusions were conformable with or cross-cutting sedimentary bedding. Samples were collected from both chilled margins and centres of the intrusions with the field appearance varying from aphanitic to phaneritic (crystals $<1 \mathrm{~cm}$ in long dimension). One sample (sample 13-WJA-C028A2) was collected from the exposed upper part of a $\sim 50 \mathrm{~m}$ sill, and stood out in being gabbroic with crystals as large as $1 \mathrm{~cm}$ in the long dimension. In addition to these samples from the South Fiord area, 19 supplemental samples of Isachsen Formation lavas from Geodetic Hills and Camp Five 
Creek were included in the sample set (locations shown in Fig. 3.2;Williamson, 1988; Williamson, unpublished data).

\subsubsection{Major and trace elements}

Rock samples were cut with a continuous-rim diamond-impregnated saw ensuring that all weathered surfaces were removed. A small section of a slab from each rock was made into a thin section puck whereas another small section was allocated to precontaminate the crusher prior to each run, thereby reducing the risk of crosscontamination. Each slabbed rock was crushed in a Bico® WD Chipmunk crusher and sieved through a 10 mesh sieve (maximum chip size $2 \mathrm{~mm}$ ) that was cleaned after each run. After each sample was crushed, the crusher was cleaned thoroughly using compressed air, water and ethyl alcohol and dried and inspected to further ensure that risk of cross-contamination was minimized. Crushed sample was then pulverized using a Rocklabs ${ }^{\circledR}$ shatterbox fitted with an agate mill head. Three runs of two minutes each per sample at 750 revolutions per minute were done and included one pre-contaminate run and two aliquots each of $\sim 10$ grams for each sample. In order to prevent cross contamination at this step, the agate mill was vigorously cleaned with water and dried with paper towel, then air-dried, and wiped with ethyl alcohol in addition to being visually inspected after each sample was processed to ensure cleanliness of the mill. In addition, prior to the first sample run and after every fifth sample, to further ensure no cross contamination of the agate mill, a run with 95\%-pure silica sand was processed. Three batches of samples, each with an internal standard (10-LT-05, a basaltic andesite from Lake Tahoe, California) were sent to ALS Geochemistry laboratories in North Vancouver, BC (http://www.alsglobal.com) for major element analysis via Inductively 
Coupled Plasma Atomic Emissions Spectrometry (ICP-AES) as well as trace and rareearth element (REE) analysis via Inductively Coupled Plasma Mass Spectrometry (ICPMS). Trace element analytical uncertainties $(1 \sigma)$ for ALS Geochemistry laboratories based on repeat analysis of the Lake Tahoe internal standard are less than 1 ppm with the exception of $\mathrm{Ba}(15.8 \mathrm{ppm}), \mathrm{Ce}(2.0 \mathrm{ppm}), \mathrm{Cr}$ (12 pm), Sr (16.0 ppm), V (8 ppm), Zr (5 ppm), $\mathrm{Co}$ (1.6 ppm), $\mathrm{Cu}(2.71 \mathrm{ppm}), \mathrm{Ni}(4.8 \mathrm{ppm}), \mathrm{Pb}(1.6 \mathrm{ppm})$ and $\mathrm{Zn}$ (3 ppm). Major element uncertainties $(1 \sigma)$ are less than $0.10 \mathrm{wt} \%$ with the exception of $\mathrm{SiO}_{2}(0.49 \mathrm{wt} \%)$, $\mathrm{Al}_{2} \mathrm{O}_{3}(0.20 \mathrm{wt} \%), \mathrm{Fe}_{2} \mathrm{O}_{3}(0.11 \mathrm{wt} \%), \mathrm{CaO}(0.15 \mathrm{wt} \%)$ and $\mathrm{Na}_{2} \mathrm{O}(0.12)$.

\subsubsection{Nd isotopes}

Rock powders were spiked with a mixed ${ }^{148} \mathrm{Nd}-{ }^{149} \mathrm{Sm}$ spike before being dissolved in a mixed solution of $\sim 29 \mathrm{M} \mathrm{HF}$ and $\sim 16 \mathrm{M} \mathrm{HNO}_{3}$. The samples were then dried down on a hotplate before being re-dissolved with $8 \mathrm{M} \mathrm{HNO}_{3}$ and $6 \mathrm{M} \mathrm{HCl}$ sequentially. The dried residue of each sample was finally dissolved in $2.5 \mathrm{M} \mathrm{HCl}$ prior to being loaded onto 14-ml Bio-Rad borosilicate glass chromatography columns containing $3.0 \mathrm{ml}$ of Dowex AG50W-X8 cation resin. REE were eluted with $2.5 \mathrm{~N} \mathrm{HCl}$ and $6 \mathrm{M} \mathrm{HCl}$, respectively. REE fractions were then dissolved in $0.26 \mathrm{M} \mathrm{HCl}$ and loaded onto Eichrom Ln Resin chromatographic columns containing Teflon powder coated with HDEHP [di(2ethylhexyl) orthophosphoric acid] (Richard et al., 1976). Nd was eluted with $0.26 \mathrm{M} \mathrm{HCl}$, followed by $\mathrm{Sm}$ with $0.5 \mathrm{M} \mathrm{HCl}$.

The isotope ratios were measured using a Thermo Finnigan Triton thermal ionization mass spectrometer (TIMS) housed at the Isotope Geochemistry and Geochronology Research Centre, Carleton University, Ottawa Canada. Nd and Sm 
fractions were loaded with $\mathrm{H}_{3} \mathrm{PO}_{4}$ onto one side of a double rhenium filament assembly. The isotope ratios were measured at temperatures of $1700-1800^{\circ} \mathrm{C}$ and are normalized to ${ }^{146} \mathrm{Nd} /{ }^{144} \mathrm{Nd}=0.72190$. An Isotope Geochemistry and Geochronology Research Centre (IGGRC)'s in-house Nd standard was routinely measured and an average value of ${ }^{143} \mathrm{Nd} /{ }^{144} \mathrm{Nd}$ ratio was $0.511826 \pm 0.000007(1 \sigma)$ over a period of three years; this value is equivalent to ${ }^{143} \mathrm{Nd} /{ }^{144} \mathrm{Nd}=0.511855$ reported for the La Jolla $\mathrm{Nd}$ standard based on comparative runs of the two standards. Sm and Nd concentrations were measured precisely within $1 \%$, whereas ${ }^{147} \mathrm{Sm} /{ }^{144} \mathrm{Nd}$ ratios are reproducible to $0.5 \%$. Analyses of the USGS standard BCR-2 yield Nd = 28.7 ppm $(\mathrm{n}=3), \mathrm{Sm}=6.7 \mathrm{ppm}(\mathrm{n}=3)$, and ${ }^{143} \mathrm{Nd} /{ }^{144} \mathrm{Nd}=0.512644 \pm 0.000012(1 \sigma, \mathrm{n}=10)$. Total procedural blanks for Nd were less than $40 \mathrm{pg}$.

\subsection{RESULTS}

\subsubsection{Petrography}

Thin section analyses of samples reveal that rocks from South Fiord intrusions and Isachsen Formation lavas show primary igneous textures and igneous mineral assemblages typical of mafic rocks. In terms of primary igneous mineralogy, the bulk of the volume (>90 vol\%) consists of plagioclase feldspar and clinopyroxene (Fig. 3.5). Olivine is either absent or rarely present in trace amounts in less differentiated samples. Free quartz exists in trace amounts in more chemically evolved samples, particularly the sample collected from the top of the $>50 \mathrm{~m}$ thick sill (Fig. 3.5A). Ilmenite and magnetite are present in varying quantities. South Fiord intrusive rocks typically display sub-ophitic textures (Fig. 3.5C \& 3.5D) whereas lavas are characterized by mm-sized plagioclase 
phenocrysts in a groundmass of plagioclase and clinopyroxene (Figs. 3.5D - 3.5E). Whereas many samples are fresh (Figs. 3.5B, D \& E), some show some degree of secondary alteration, saussuritized plagioclase and amphibole-after-clinopyroxene (Figs. 3.5C \& 3.5F). Such evidence of alteration likely caused varying degrees of mobility of large ion lithophile elements and silica. Therefore, this study relies mostly on the systematics of the more immobile high field strength and REE rather than total-alkali silica systematics (cf., LeBas et al., 1986).

Figure 3.5 (next page): Crossed-polar photomicrographs of samples from the South Fiord intrusives (A-C) and Isachsen Formation lavas (D-F) with sample ID numbers included. (A) sample of gabbro of having basaltic andesite composition from the $>50 \mathrm{~m}$ sill, (B) representative sample of fresh sub-ophitic dolerite, (C) representative sub-ophitic dolerite showing alteration of primary mineralogy; (D-E) representative unaltered lavas showing phenocrysts of plagioclase within a groundmass of plagioclase and clinopyroxene, (F) Isachsen Formation lava showing extensive alteration of plagioclase phenocrysts and in the groundmass to clay. Key to mineral ID: $\mathrm{Pl}=$ plagioclase; $\mathrm{Cpx}=$ clinopyroxene; $\mathrm{Qtz}=$ quartz; Ox $=$ oxides. 

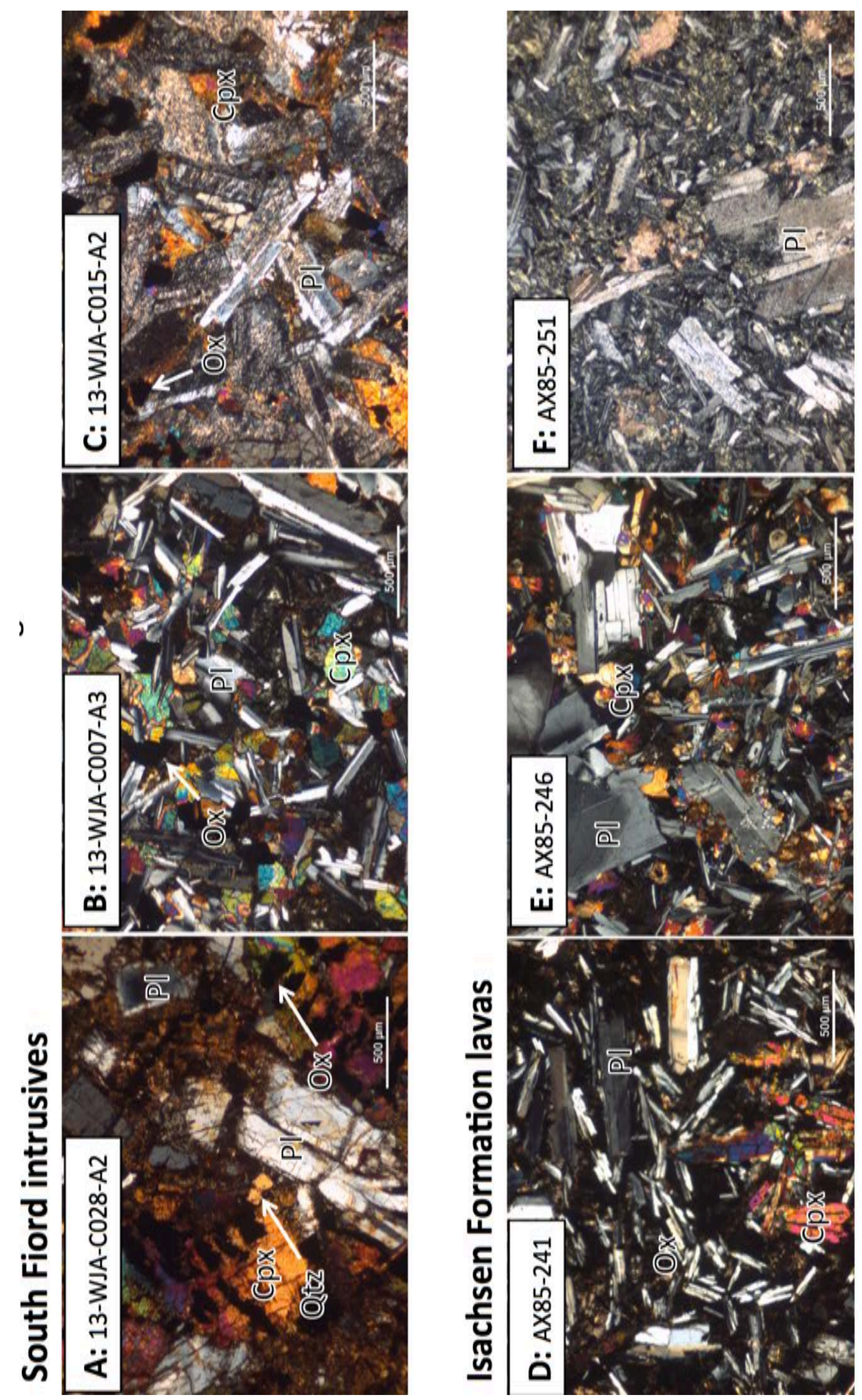


\subsubsection{Major and trace elements}

In terms of total alkali-silica major element classification of LeBas et al. (1986) the three magmatic suites of this study, the intrusive rocks of the South Fiord area ("South Fiord intrusives") along with the lavas of the Isachsen and Strand Fiord Formation are classified as basalts to basaltic andesites (Fig. 3.6). The Strand Fiord Formation data are from Jowitt et al. (2014). A few samples from Isachsen Formation lavas are silica-poor having $\mathrm{SiO}_{2} 41 \%$ - 45\%. Furthermore, based on the AFM diagram of Irvine and Baragar (1971), all South Fiord intrusive rocks and lavas of the Isachsen Formation and Strand Fiord Formation are tholeiitic (Fig. 3.7). Harker plots showing the relationship between $\mathrm{SiO}_{2}$ and several major elements are shown in Figure 3.8. Strand Fiord Formation lavas along with South Fiord intrusive rocks show no discernable trends in $\mathrm{Al}_{2} \mathrm{O}_{3}, \mathrm{MgO}, \mathrm{TiO}_{2}$ and $\mathrm{P}_{2} \mathrm{O}_{5}$ but there appears to be a wide variance in $\mathrm{K}_{2} \mathrm{O}(0.2-2$ wt $\%$ ) within a narrow $\mathrm{SiO}_{2}$ range $(45-55 \mathrm{wt} \%)$, a trend that is similarly shown in $\mathrm{Na}_{2} \mathrm{O}$ space. The Isachsen Formation lavas, in contrast, appear silica -poor when compared with the South Fiord intrusive rocks along with the Strand Fiord Formation lavas. The unusual compositions of some of these lavas (e.g. picrobasalt) may be due to alteration caused by evaporite interaction which is discussed in this chapter in Section 3.4.7.

Utilizing immobile trace element compositions (Appendix 2), all but one sample collected near South Fiord, Camp Five Creek and Geodetic Hills are chemically classified as subalkaline basalts on the basis of $\mathrm{Nb} / \mathrm{Y}$ vs. $\mathrm{Zr}$ /Ti systematics (Fig. 3.9A; Pearce and Norry, 1979). The exception plots as basaltic andesite and was collected from the upper portion of a 50 m-thick sill near South Fiord (sill S10; Chapter 2; Table 2.2). 


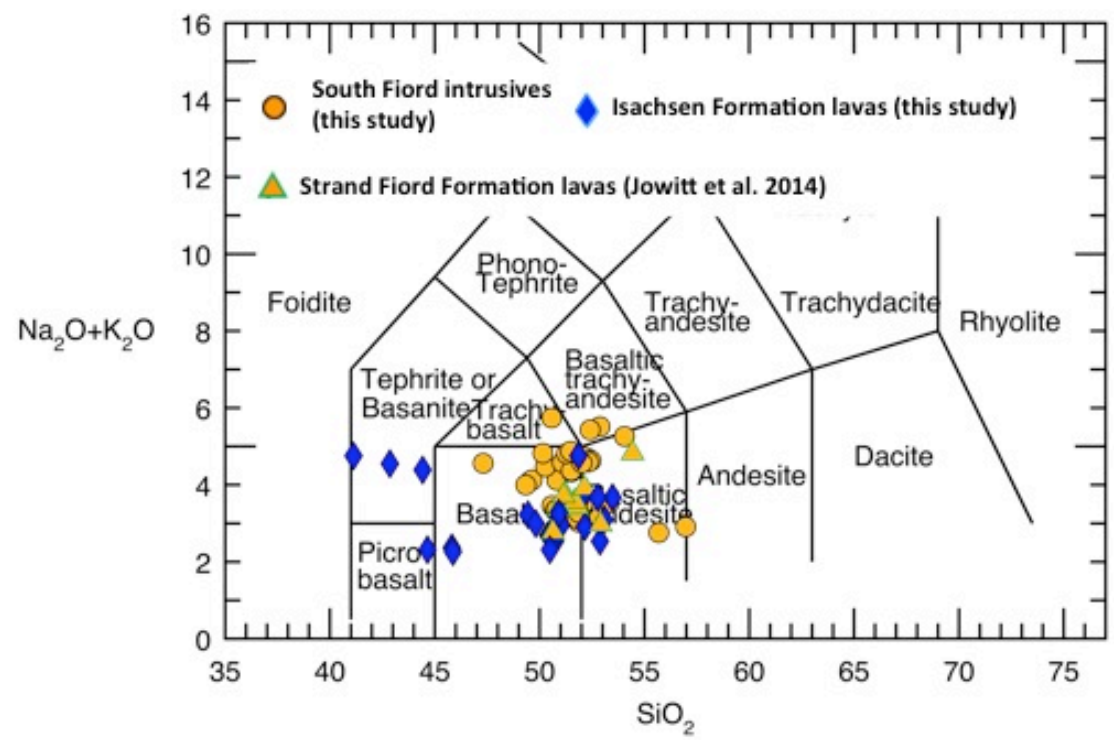

Figure 3.6: Total alkali vs. silica diagram of HALIP mafic rocks. Classification based on LeBas et al. (1986).

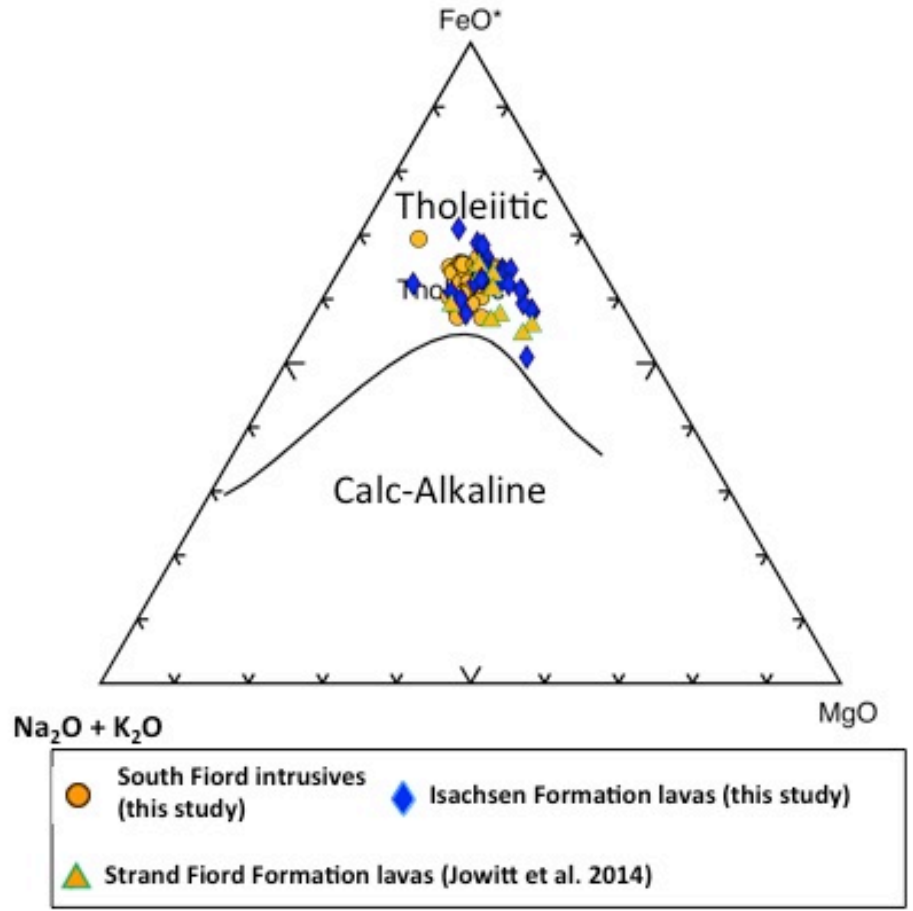

Figure 3.7: Total alkali - Iron - Magnesium (AFM) ternary plot of HALIP rocks. Classification diagram from Irvine and Baragar (1971). 

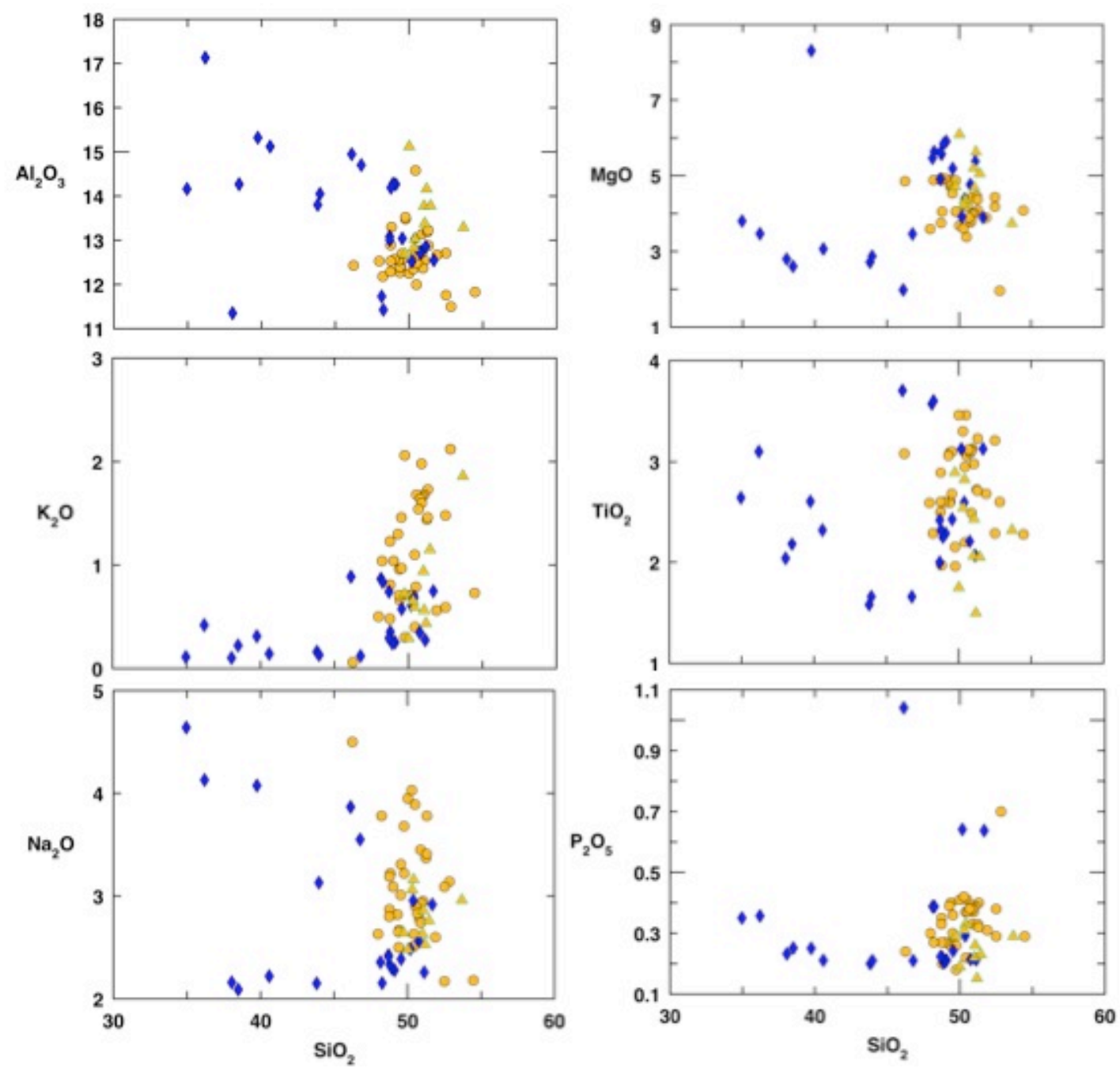

Figure 3.8: $\mathrm{SiO} 2$ versus various major element oxides of HALIP rocks. Symbols are as Figure 3.7.

Figure 3.9 (next page): (a) $\mathrm{Nb} / \mathrm{Y}$ vs. $\mathrm{Zr} / \mathrm{Ti}$ classification of lavas and intrusive rocks in this study based on the scheme of Pearce and Norry (1979). Data normalized on a volatile-free basis. The one sample in the andesite field is the highly differentiated gabbro (Sample 13-WJA-C028A2) whereas the Strand Fiord Formation lavas plot with the South Fiord intrusives and Isachsen lavas, (b) $\mathrm{Nb} / \mathrm{Yb}$ vs. Th/Yb classification systematics of Pearce (2008). Note that all samples plot above E-MORB signifying magma-crust interaction. Key to reference footnote: [1] (Jowitt et al., 2014). 


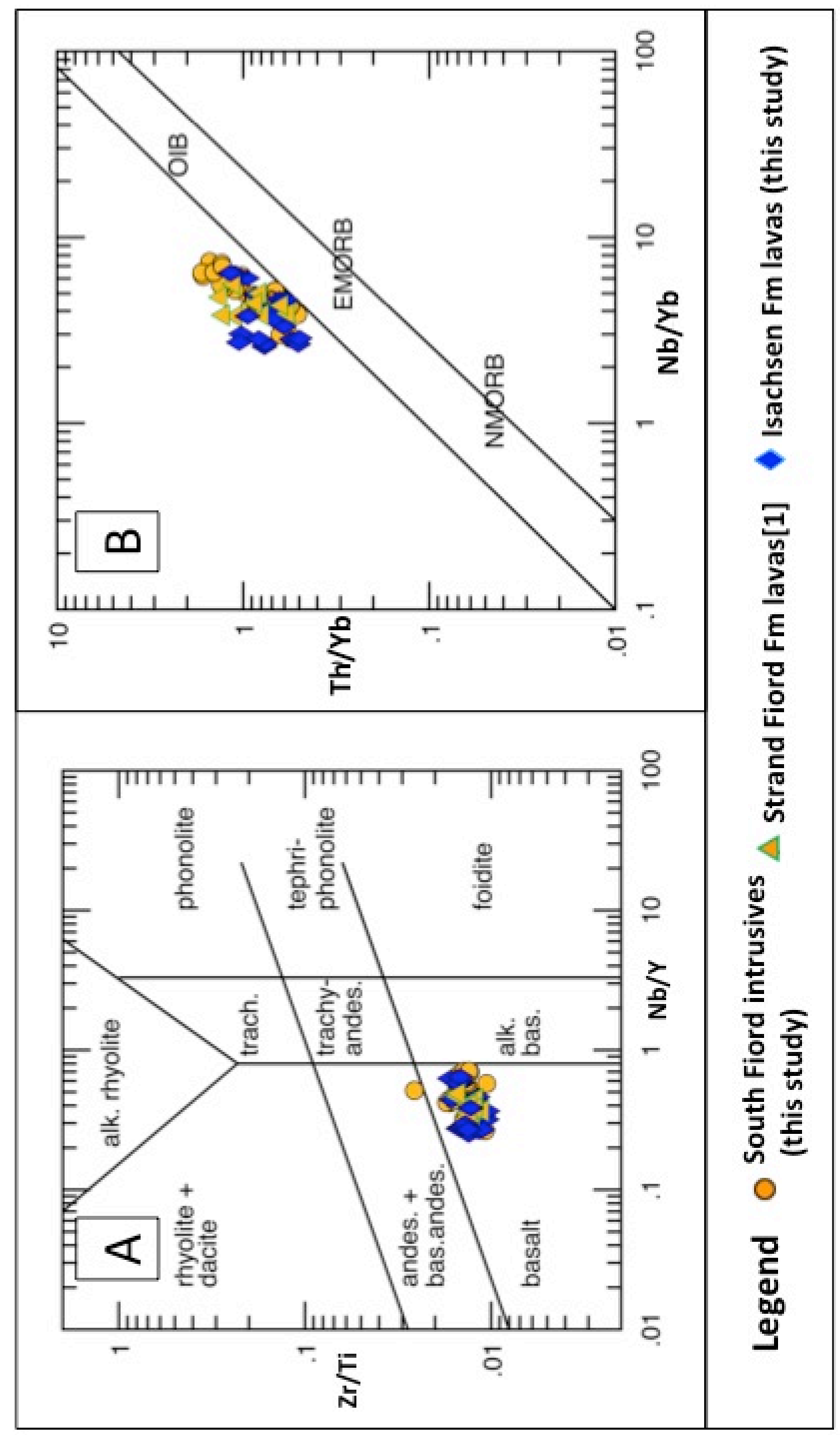


When the intrusive rocks collected in the South Fiord locality are compared with Isachsen Formation lavas from Camp Five Creek and Geodetic Hills, the two suites not only plot largely as subalkaline basalts, but display nearly identical $\mathrm{Nb} / \mathrm{Y}$ vs. $\mathrm{Zr} / \mathrm{Ti}$ compositional ranges. Furthermore, in a $\mathrm{Nb} / \mathrm{Yb}$ vs. $\mathrm{Th} / \mathrm{Yb}$ plot, the South Fiord intrusives along with Isachsen Formation lavas plot slightly above the Enriched Mid-Ocean Ridge Basalt (E-MORB) section of the Normal Mid-Ocean Ridge Basalt (N-MORB) - Ocean Island Basalt (OIB) diagonal array (Pearce, 2008; Fig. 3.9B). This indicates that the parental magmas and lavas (a) have chemistries consistent with E-MORB and (b) have Th enrichment consistent with some degree of interaction with crustal material. $\mathrm{Tb} / \mathrm{Yb} \mathrm{b}_{\mathrm{N}}$ (a proxy for melting depth) of intrusive samples from the South Fiord region cluster tightly between $\sim 1.3$ and $\sim 1.5$ with one sample having a lower $\mathrm{Tb} / \mathrm{Yb}_{\mathrm{N}}$ of 1.1 (Fig. 3.10). $\mathrm{The} \mathrm{Tb} / \mathrm{Yb}_{\mathrm{N}}$ values of Isachsen Formation lavas from the South Fiord area largely overlap with those from Camp Five Creek and Geodetic Hills areas and many of these samples also largely overlap with the South Fiord intrusive data, but there are a significant number of samples with higher ratios (1.6-1.8). Figure 3.11 shows the relationship between $\mathrm{Gd} / \mathrm{Yb}$ (another proxy for depth of partial melting with higher values signifying melting in the garnet stability field) and La/Sm (higher values signify greater source enrichment, crustal assimilation and/or lower degree of partial melting; Pearce, 2008). The Isachsen Formation lavas can be divided into two groups: one displaying low La/Sm and a second displaying higher $\mathrm{La} / \mathrm{Sm}$. These two groups show little variation of $\mathrm{La} / \mathrm{Sm}$ and a wide variation of $\mathrm{Gd} / \mathrm{Yb}$ within each group. Conversely, intrusive rocks from the South Fiord locality display a comparatively narrow $\mathrm{Gd} / \mathrm{Yb}$ 
range (occupying the lower half of the Isachsen Formation flow array) and a wider range in $\mathrm{La} / \mathrm{Sm}$.

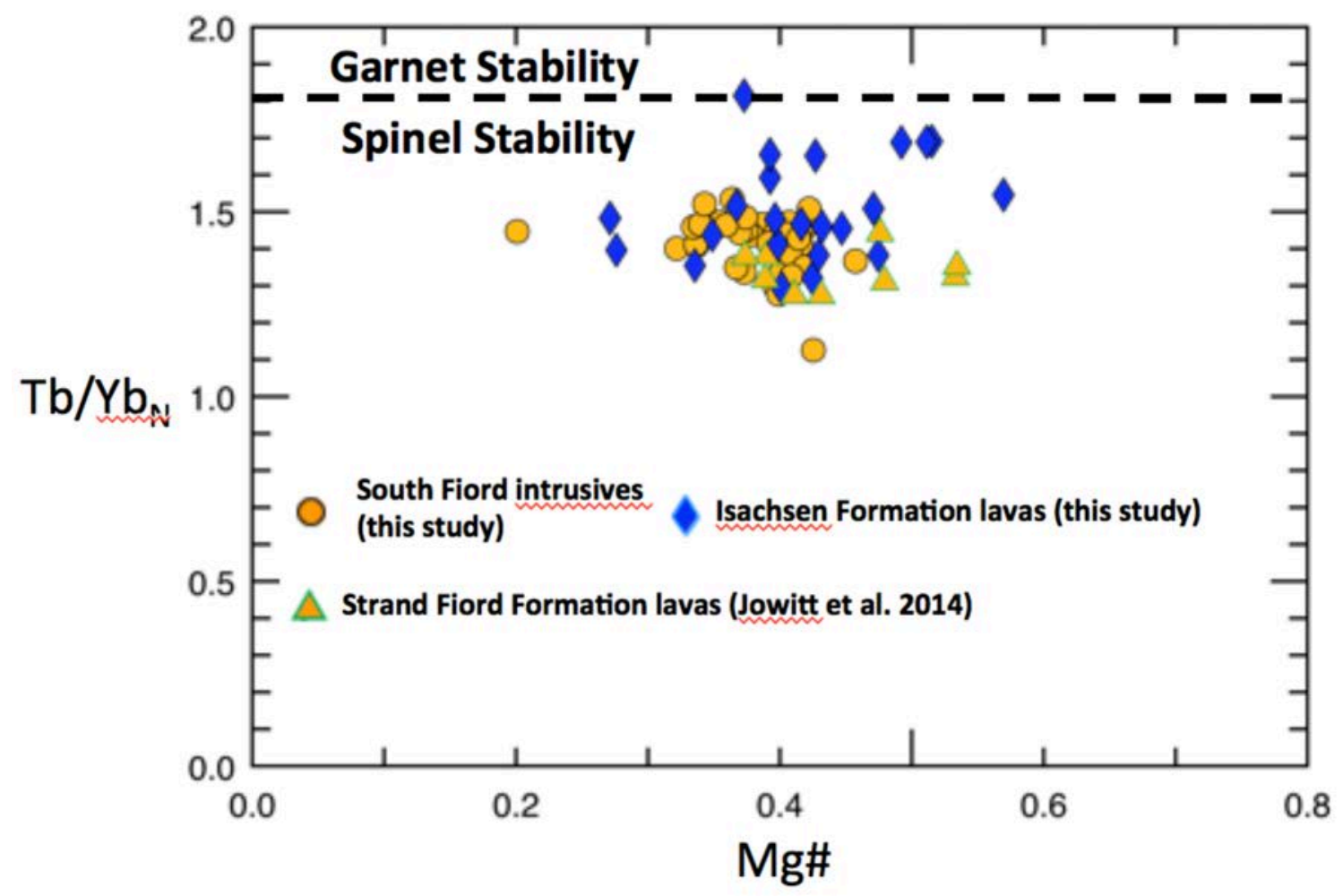

Figure 3.10: $\mathrm{Mg \#}$ vs. $\mathrm{Tb} / \mathrm{Yb}(\mathrm{N})$ diagram. Note that the Isachsen Formation lavas display chemical evidence of deeper melting those that of the South Fiord intrusives and the Strand Fiord Formation lavas. Tb/Yb values are normalized to McDonough and Sun (1995) and the spinel-garnet transition line is from (Wang et al., 2002). Symbols used herein are the same as Figure 3.9.

Figure 3.12 compares the chondrite-normalized REE patterns (Sun and McDonough, 1989) of the South Fiord intrusives (Fig. 3.12A) with the Isachsen Formation lavas (Fig. 3.12B). Both suites show enrichment of light REE relative to the heavy REE, with patterns similar to those of E-MORB (Sun and McDonough, 1989). 
Furthermore, both suites show a shallow middle - heavy REE slope in addition to small negative europium anomalies that signify fractionation of plagioclase. Whereas the range of $\mathrm{La} / \mathrm{Sm}$ in rocks of the South Fiord intrusives and the Isachsen Formation lavas are similar, the South Fiord intrusive rocks exhibit a smaller range in $\mathrm{La} / \mathrm{Sm}$.

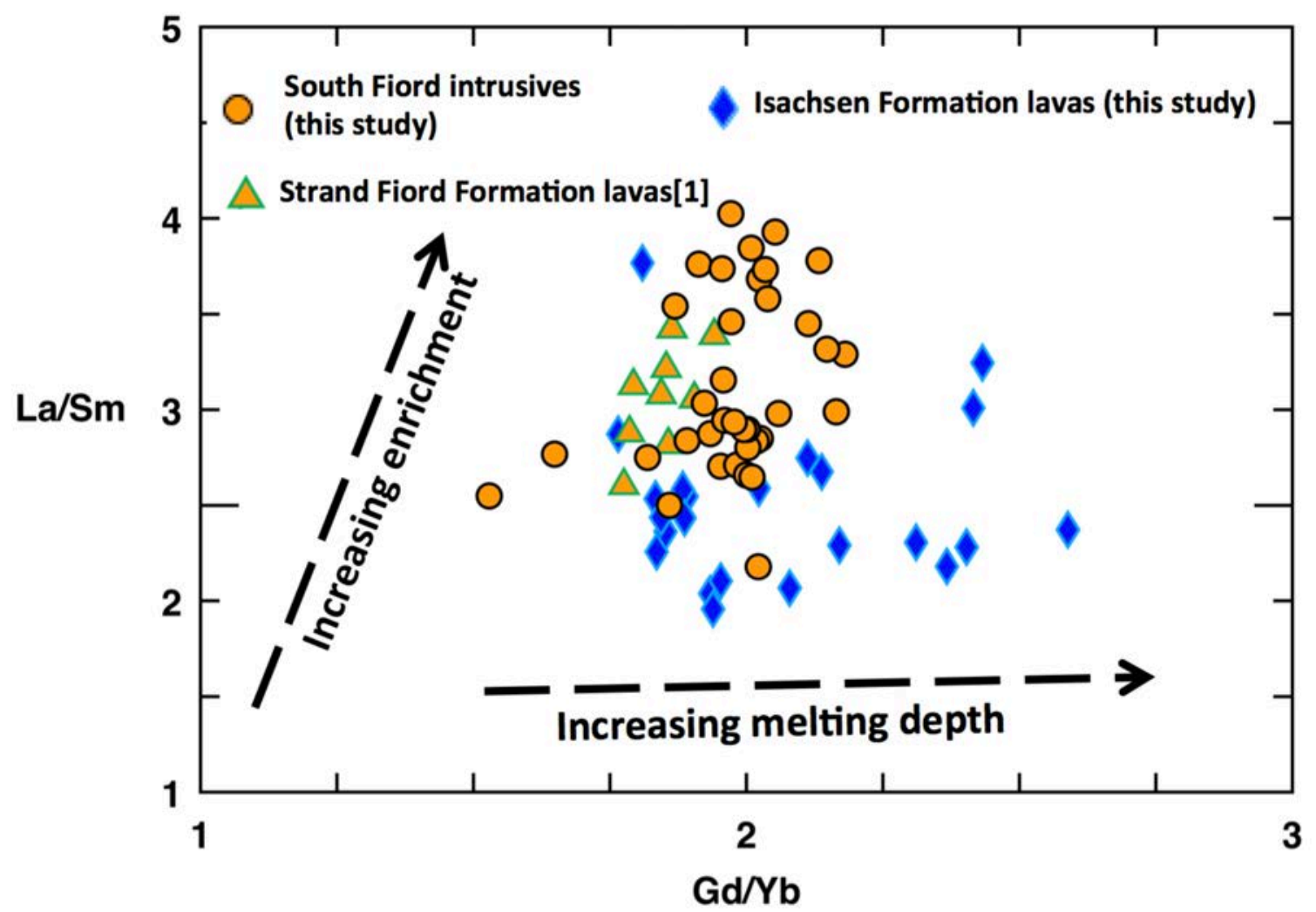

Figure 3.11: $\mathrm{Gd} / \mathrm{Yb}$ vs. La/Sm plot showing the evolutionary trends of Isachsen Formation lavas, the South Fiord intrusives and Strand Fiord Formation lavas (data from Jowitt et al., 2014). Note the wider range of $\mathrm{Gd} / \mathrm{Yb}$ of the Isachsen Formation lavas when compared to the South Fiord intrusives and Strand Fiord Formation lavas, signifying greater range of melting depth. Conversely, the wider range of $\mathrm{La} / \mathrm{Sm}$ on the part of South Fiord intrusives and Strand Fiord Formation lavas would suggest an enrichment trend. Dashed arrows denote approximate trends. Full discussion in the text. 
South Fiord intrusives

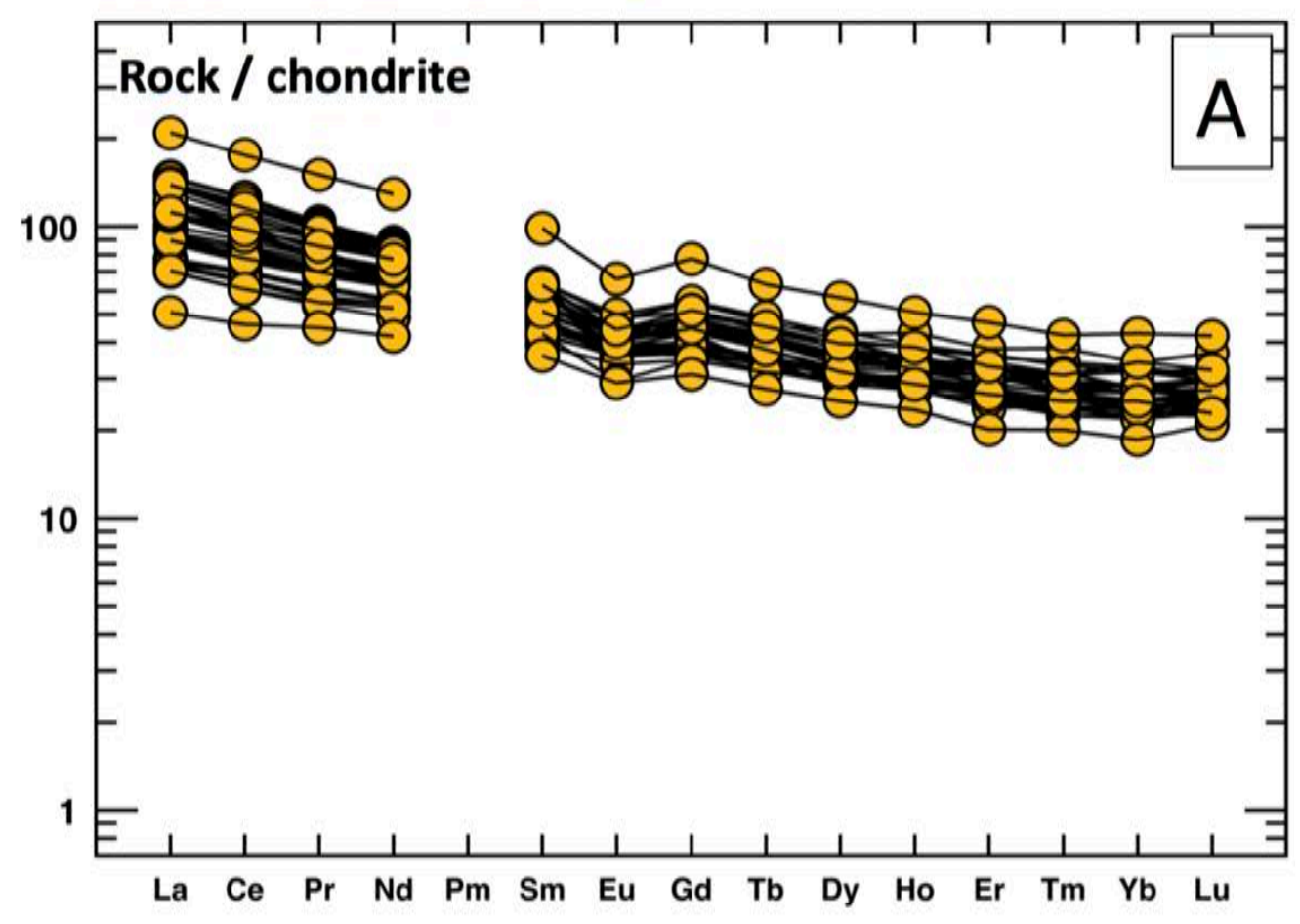

\section{Isachsen Formation lavas}

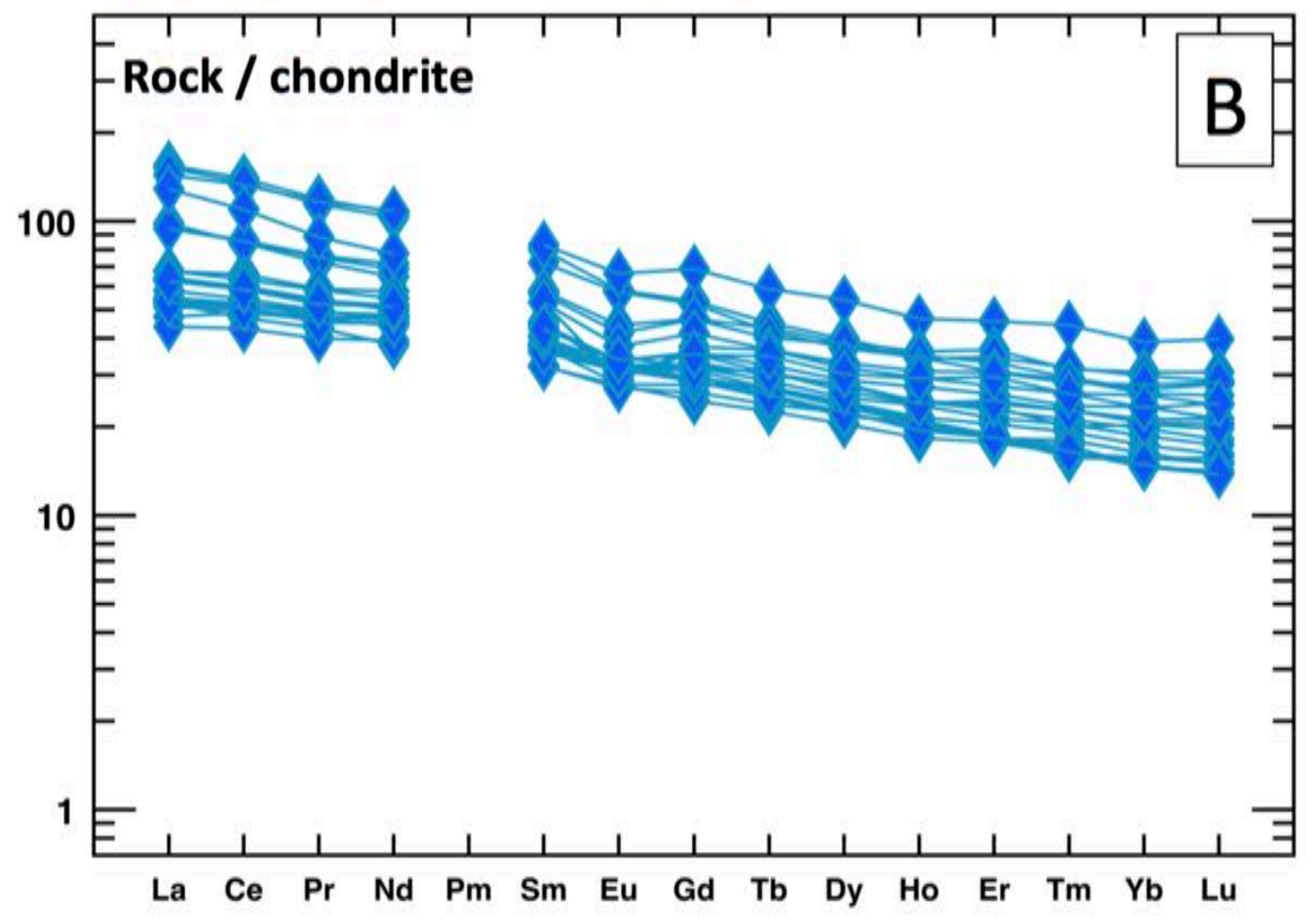

Figure 3.12: Chondrite-normalized REE diagrams normalized to Sun and McDonough (1989) of (A) South Fiord intrusives and (B) Isachsen Formation lavas. 
Primitive mantle-normalized (Sun and McDonough, 1989) incompatible element patterns in Figure 3.13 show that South Fiord intrusives (Fig. 3.13A) and Isachsen Formation lavas (Fig. 3.13B) have broadly similar patterns. They both show negative anomalies in Sr and P. Furthermore, some samples of South Fiord intrusives and Isachsen Formation lavas show small negative Nb-Ta anomalies, but there is a subpopulation of samples of each having negative $\mathrm{K}$ anomalies (adjacent to Ta) which masks the overall appearance for those samples displaying the $\mathrm{Nb}-\mathrm{Ta}$ anomaly. One feature in which the Isachsen Formation lavas as a group diverge from the South Fiord intrusives is that the Isachsen Formation lavas have more prominent negative anomalies in the largeion lithophile elements $(\mathrm{Rb}, \mathrm{K}, \mathrm{Sr})$ as well as less prominent positive $\mathrm{Pb}$ anomalies.

With the exception of a chemically evolved gabbro $(\mathrm{MgO}=1.5 \mathrm{wt} \%$; sample 13 WJA-C028-A2), $\mathrm{MgO}$ contents in the South Fiord intrusives range from $3-5 \mathrm{wt} \%$ (Fig. 3.14). Isachsen Formation lavas have $\mathrm{MgO}$ contents from 1.5 - $6 \mathrm{wt} \%$. Relative to oceanic basalts, these $\mathrm{MgO}$ contents are indicative of chemically evolved rocks that have experienced fractionation of mafic minerals. All but one sample of the South Fiord intrusives and all Isachsen lavas have Sc contents ranging from 29 to 59 ppm (Fig. 3.14A) (the evolved gabbro of Sill S10 in Chapter 2, Table 2.2 contains $21 \mathrm{ppm} \mathrm{Sc).}$ Most of the Isachsen Formation lavas have lower Sc in more evolved (lower $\mathrm{MgO}$ ) lavas suggesting that clinopyroxene was a major fractionating phase. The Strand Fiord Formation lavas (Jowitt et al., 2014) also show a clinopyroxene fractionation pattern like the Isachsen Formation lavas. The South Fiord intrusives, however, show no obvious clinopyroxene fractionation trend. Ni contents (Fig. 3.14B) for the South Fiord intrusives are $<50 \mathrm{ppm}$, whereas higher concentrations of up to $80 \mathrm{ppm}$ are recorded for the 
South Fiord intrusives

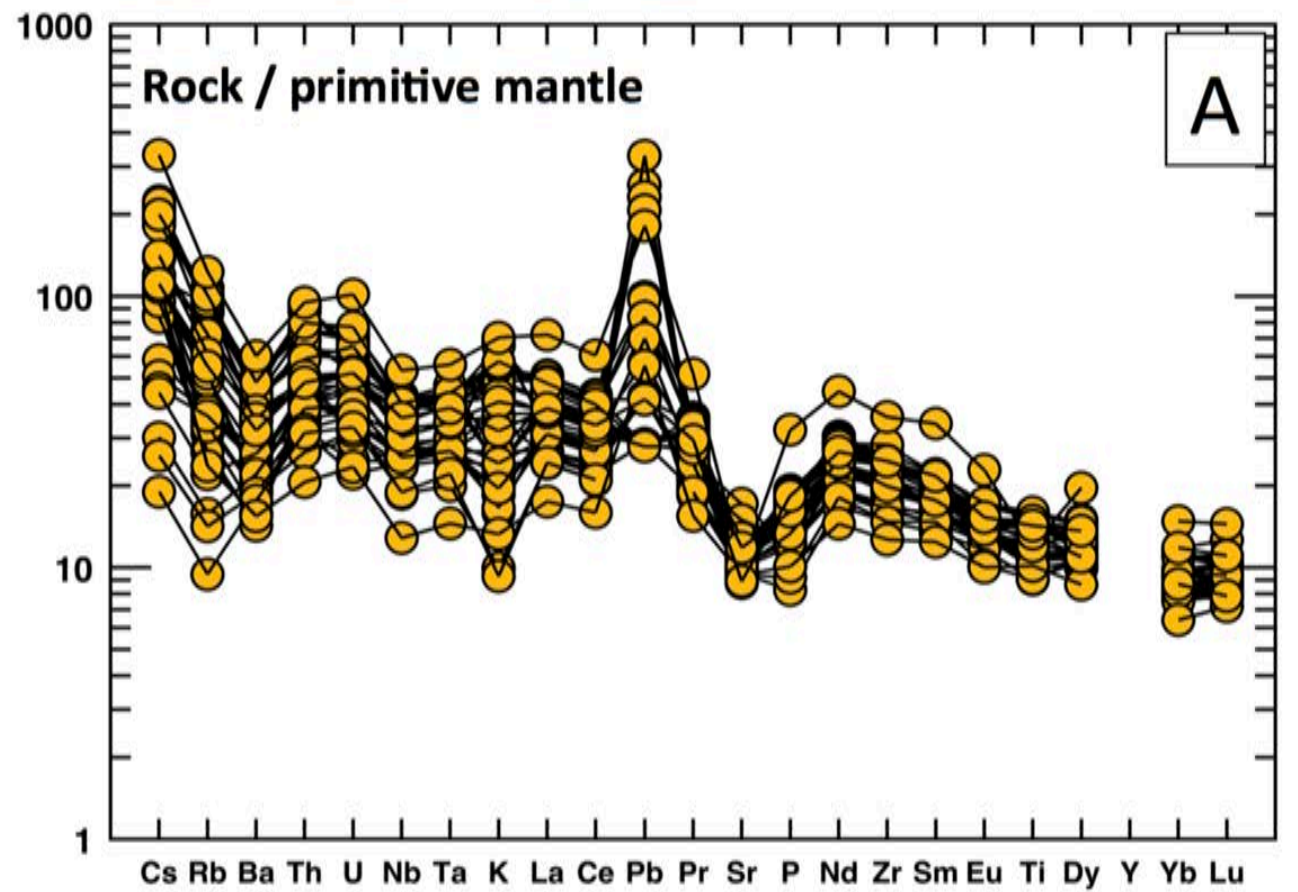

Isachsen Formation lavas

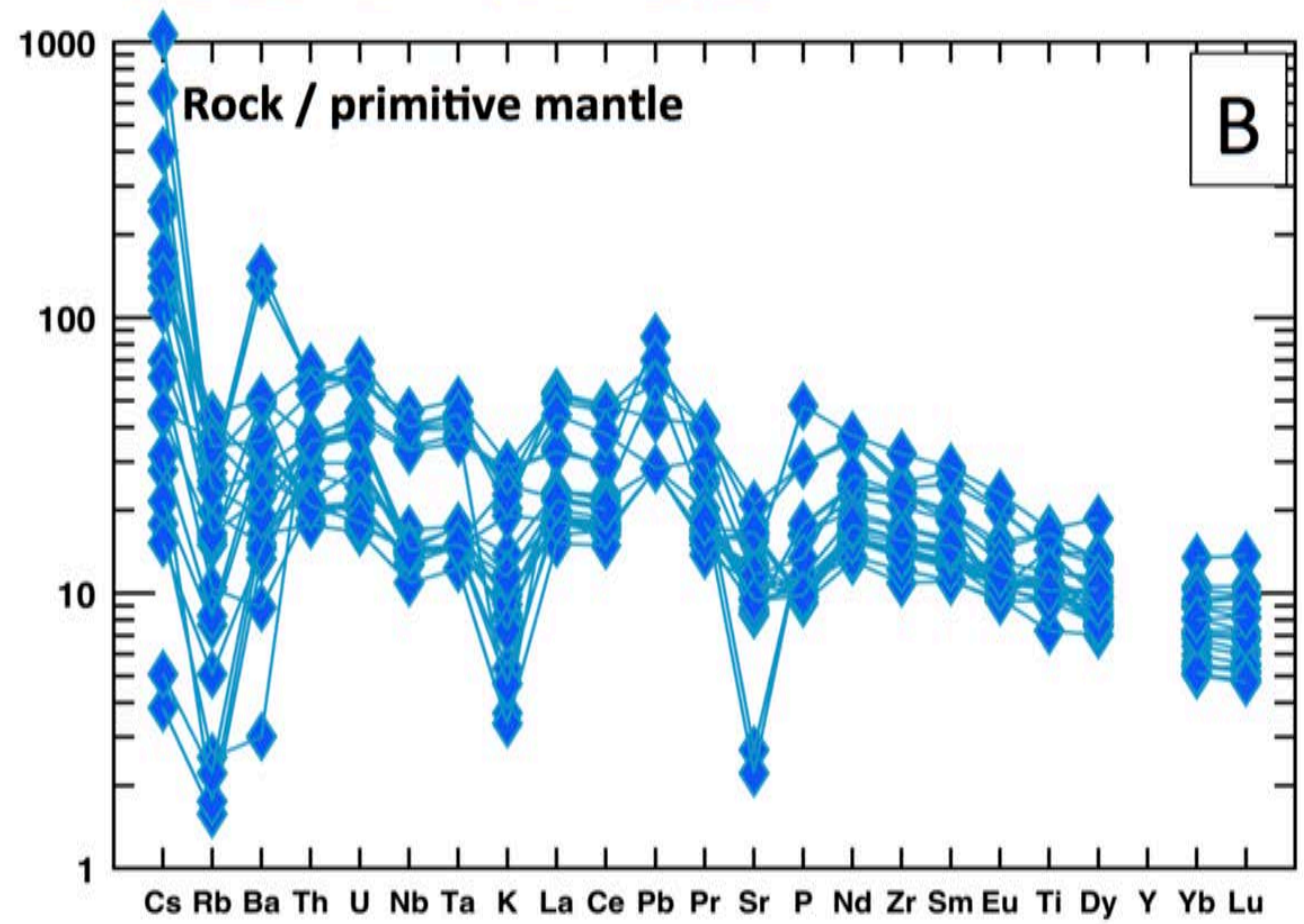

Figure 3.13: Trace element ratio diagrams normalized to primitive mantle of Sun and McDonough (1989). (A) South Fiord intrusives and (B) Isachsen Formation lavas. 

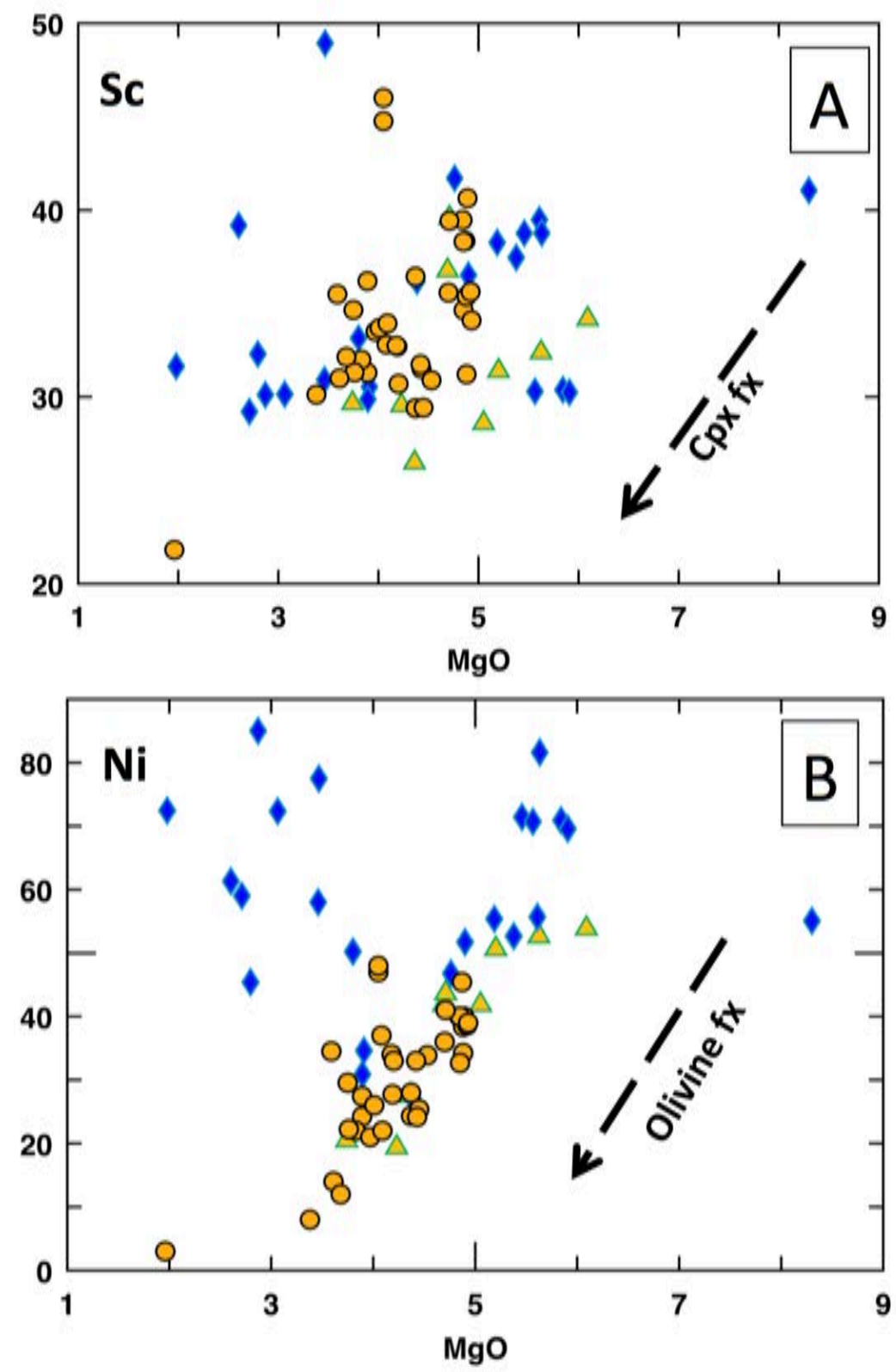

South Fiord intrusives (this study)

Isachsen Formation lavas (this study)

\section{Strand Fiord Formation lavas[1]}

Figure 3.14: (a) $\mathrm{MgO}$ (wt\%) vs. Sc (ppm) variation plot showing how South Fiord intrusives, Isachsen Formation lavas and Strand Fiord Formation lavas evolve with respect to clinopyroxene fractionation (fx). Note Isachsen Formation and Strand Fiord Formation lavas show a moderate fractionation trend. (b) $\mathrm{MgO}$ (wt \%) vs. $\mathrm{Ni}$ (ppm) variation plot showing how South Fiord intrusives, Isachsen Formation lavas and Strand Fiord Formation lavas evolve with respect to olivine fractionation (fx). Note strong olivine fractionation trend for the South Fiord intrusives and Strand Fiord Formation lavas, but no obvious olivine fractionation occurring with the Isachsen Formation lavas. 
Isachsen Formation lavas, and would indicate that Isachsen Formation lavas are less evolved. Furthermore, in these Isachsen lavas there is no consistent correlative trend between $\mathrm{Ni}$ and $\mathrm{MgO}$. On the other hand, the Strand Fiord Formation lavas (Jowitt et al., 2014) have Ni contents largely overlapping with the South Fiord intrusives (20 -55 ppm) and show a clear positive correlation (increasing $\mathrm{Ni}$ with commensurate increase in $\mathrm{MgO})$.

Figure 3.15 shows the relationship between $\mathrm{Ba} / \mathrm{Nb}$ and $\mathrm{Ba} / \mathrm{Th}$. The South Fiord intrusives have $\mathrm{Ba} / \mathrm{Nb}$ ratios between 0.5 - 16 whereas the Isachsen Formation lavas display a much wider range of $0.5-39$. Most of the Isachsen Formation lavas are enriched in $\mathrm{Ba}$ compared to $\mathrm{Nb}$ and especially to $\mathrm{Th}$ when compared to the South Fiord intrusives. Furthermore, the Isachsen Formation lavas display a strong positive correlation between $\mathrm{Ba} / \mathrm{Nb}$ and $\mathrm{Ba} / \mathrm{Th}$ whereas the South Fiord intrusives show a positive correlation, yet are more clustered as a reflection of the limited range in $\mathrm{Ba} / \mathrm{Nb}$ and $\mathrm{Ba} / \mathrm{Th}$ values. Compared to average E-MORB $(\mathrm{Ba} / \mathrm{Nb}=7 ; \mathrm{Ba} / \mathrm{Th}=95 ; \mathrm{Sun}$ and $\mathrm{McDonough}$, 1989) the South Fiord intrusions are low in $\mathrm{Ba} / \mathrm{Th}$ whereas Isachsen Formation lavas are both low and high in $\mathrm{Ba} / \mathrm{Th}$. A majority of South Fiord intrusives and Isachsen Formation lavas are enriched in $\mathrm{Ba} / \mathrm{Nb}$ compared to average $\mathrm{E}-\mathrm{MORB}$ values. Finally, when compared with the weighted compositional average of Sverdrup Basin sedimentary $\operatorname{rocks}(\mathrm{Ba} / \mathrm{Nb}=36 ; \mathrm{Ba} / \mathrm{Th}=40 ;$ Patchett et al., 2004), most samples from both South Fiord intrusives and Isachsen Formation lavas are low in $\mathrm{Ba} / \mathrm{Th}$ whereas several Isachsen Formation lavas are much higher in $\mathrm{Ba} / \mathrm{Th}$. 


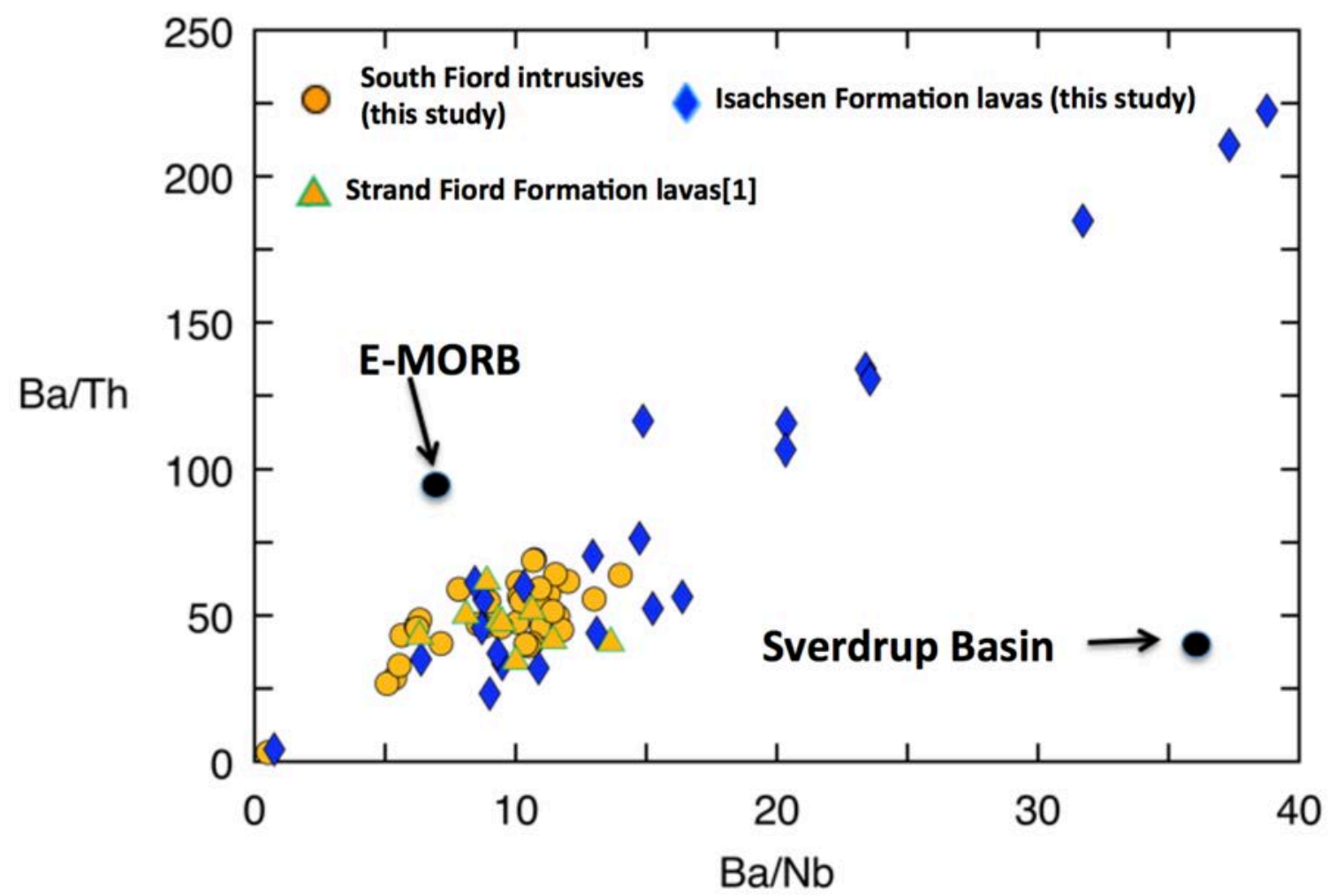

Figure 3.15: $\mathrm{Ba} / \mathrm{Nb}$ vs $\mathrm{Ba} / \mathrm{Th}$ plot showing distribution of data for the South Fiord intrusives, the Isachsen Formation lavas as well as the Strand Fiord Formation lavas. EMORB point derived from Sun and McDonough (1989) whereas Sverdrup Basin point is a weighted average (described in the text) from Patchett et al. (2004). Data from Strand Fiord Formation lavas are from Jowitt et al. (2014).

Figure 3.16 is a plot showing the relationship between Th/La and $\mathrm{Ba} / \mathrm{Th}$ in the South Fiord intrusives, Strand Fiord Formation lavas (Jowitt et al., 2014) and Isachsen Formation lavas. South Fiord intrusives, Strand Fiord Formation lavas (Jowitt et al., 2014) and a part of the Isachsen Formation lavas show wide range in Th/La $(0.13-0.25)$ with near uniform $\mathrm{Ba} / \mathrm{Th}$ ratios $(\sim 60)$. Furthermore, these data plot between E-MORB (Sun and McDonough, 1989) and the weighted average composition of sedimentary rocks of the Sverdrup Basin (Patchett et al., 2004). The remainder of the Isachsen Formation lavas (about half of the total Isachsen Formation sample set herein presented) have near uniform Th/La ratios $(\sim 0.14)$ but have a comparatively wide range in $\mathrm{Ba} / \mathrm{Th}(60-220)$. 


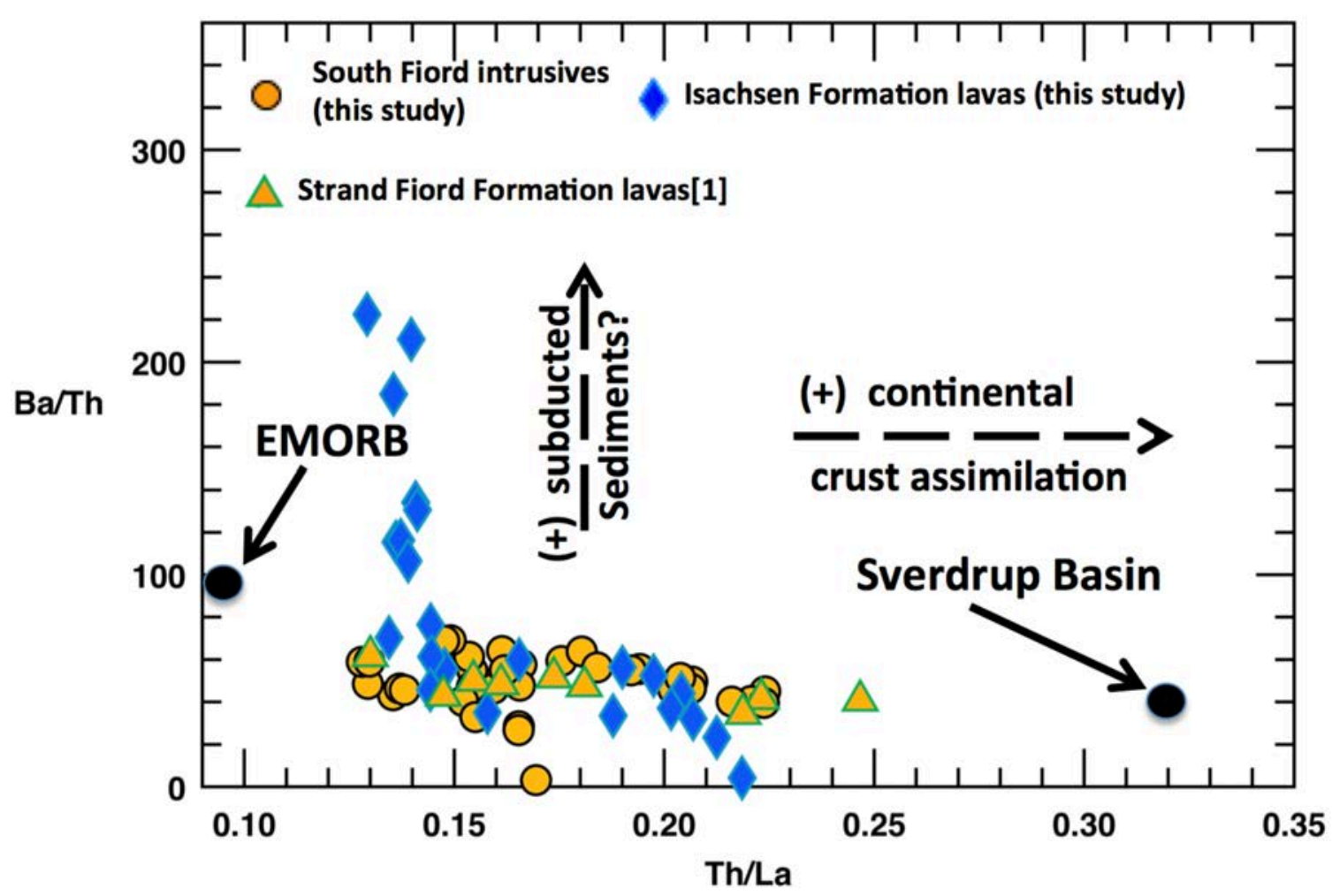

Figure 3.16: $\mathrm{Th} / \mathrm{La}$ vs $\mathrm{Ba} / \mathrm{Th}$ plot showing distribution of data for the South Fiord intrusives, the Isachsen Formation lavas as well as the Strand Fiord Formation lavas. The E-MORB point derived from Sun and McDonough (1989) whereas the Sverdrup Basin point is a weighted average (described in the text) from Patchett et al. (2004). Data from Strand Fiord Formation lavas are from Jowitt et al. (2014).

\subsubsection{Nd isotopes}

For this study, we performed Nd Isotopic analyses on eight samples from South Fiord intrusions, two samples from an Isachsen Formation lava flow exposed in the South Fiord region, and 10 samples of Isachsen Formation lavas collected in Geodetic Hills and Camp Five Creek areas (Williamson, 1988; Williamson, unpublished data). These data can be found in Appendix 3.

The South Fiord intrusives range in present-day ${ }^{143} \mathrm{Nd} /{ }^{144} \mathrm{Nd}$ from 0.51265 to $051285,{ }^{147} \mathrm{Sm} /{ }^{144} \mathrm{Nd}$ from 0.145 to 0.160 and display a modestly-scattered positive correlation on a ${ }^{147} \mathrm{Sm} /{ }^{144} \mathrm{Nd}$ vs. ${ }^{143} \mathrm{Nd} /{ }^{144} \mathrm{Nd}$ errorchron diagram (Fig. 3.17). When agecorrected to $105 \mathrm{Ma}$ (average of expected range of the main HALIP pulses between ca. 
95 and $120 \mathrm{Ma}$ ), $\varepsilon \mathrm{Nd}_{\mathrm{t}}$ ranges from +1.0 to +4.5 . Relative to the Isachsen Formation lavas (described below), less scatter exists in either ${ }^{147} \mathrm{Sm} /{ }^{144} \mathrm{Nd}$ or ${ }^{143} \mathrm{Nd} /{ }^{144} \mathrm{Nd}$ as one moves from high to low ${ }^{143} \mathrm{Nd} /{ }^{144} \mathrm{Nd}$ for the South Fiord intrusives. The South Fiord intrusives overlap with Strand Fiord Formation lavas (Estrada and Henjes-Kunst, 2004) suggesting a common source and common evolutionary processes. In contrast, Isachsen Formation lavas show high degree of scatter in ${ }^{147} \mathrm{Sm} /{ }^{144} \mathrm{Nd}(0.14-0.17)$ in lavas with the highest ${ }^{143} \mathrm{Nd} /{ }^{144} \mathrm{Nd}$. The most primitive South Fiord intrusive sample (13_WJA_C032A, $\mathrm{MgO}=4.9 \mathrm{wt} \%$ ) has an ${ }^{143} \mathrm{Nd} /{ }^{144} \mathrm{Nd}$ of 0.512808 whereas the most primitive Isachsen Formation lava selected for $\mathrm{Nd}$ isotopic analyses (AX85-263, $\mathrm{MgO}=5.9 \mathrm{wt} \%$ ) has an ${ }^{143} \mathrm{Nd} /{ }^{144} \mathrm{Nd}$ of 0.512896 (Fig. 3.14). The South Fiord intrusives, along with the Strand Fiord Formation lavas (Estrada and Henjes-Kunst, 2004), appear to form a scattered SmNd errorchron in Figure 3.17. Using equation 4.11 of Faure and Mensing (2005), we calculate a Sm-Nd errorchron age of $1.318 \pm 0.6 \mathrm{Ga}(2 \sigma, \mathrm{MSWD}=38)$ for the South Fiord intrusives [2 $\sigma$ uncertainties from Ludwig (1991)]. This age is significantly older than the 130-90 Ma emplacement ages obtained from U-Pb studies on the HALIP intrusions and thus constitutes either an errorchron or a scattered mixing line.

Figure 3.17 (Next Page): Sm-Nd whole-rock errorchron diagram. Annotated samples (circled) represent the highest $\mathrm{MgO}$ concentration amongst analyzed South Fiord intrusives (Sample 13_WJA_C032A) and Isachsen Formation lavas (Sample AX85-263). Note the more even spread of South Fiord intrusive data in contrast to the clustering of Strand Fiord Formation lava data. Also note greater scatter of the Isachsen Formation lava data relative to South Fiord intrusive rocks and Strand Fiord lavas; see discussion in the text. Data from Strand Fiord Fm lavas (orange triangles) and a portion of Isachsen Fm lavas (smaller blue diamonds) are from Estrada and Henjes-Kunst (2004). 


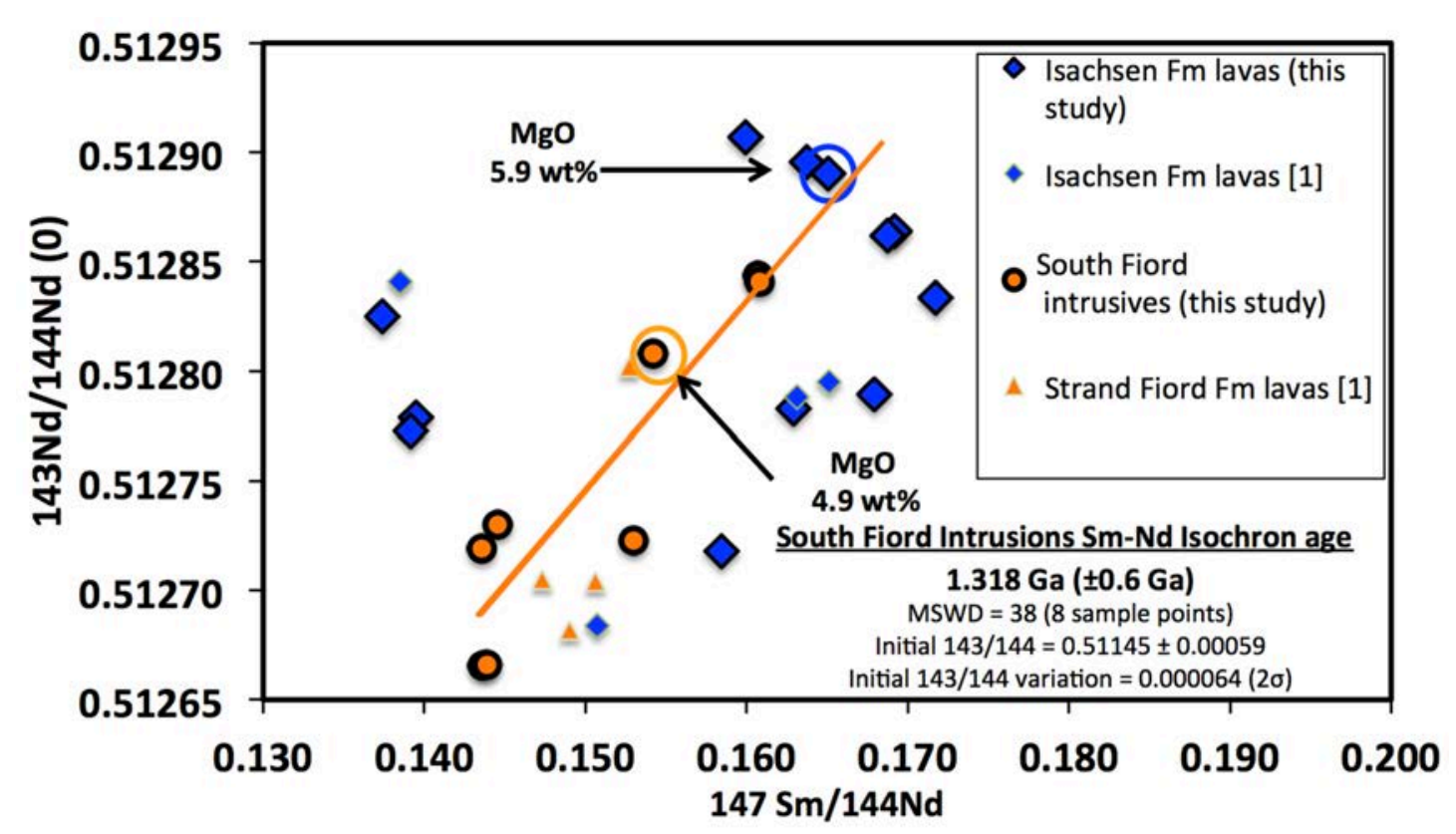

\subsection{DISCUSSION}

It has been established in Subsection 3.3.2 that all Isachsen Formation lavas and nearly all South Fiord intrusive samples are tholeiitic basalts to basaltic andesites based on major element concentrations (LeBas et al., 1986; Irvine and Baragar, 1971) however there are some samples which show silica depletion. One sample from a South Fiord intrusion is a subalkaline basaltic andesite while all others are subalkaline basalts based on trace element ratios based on the Pearce and Norry (1979) classification (Figs. 3.6, 3.7 and 3.9A, respectively). All samples show light REE enrichment with respect to middle REE along with a shallow slope between Gd and $\mathrm{Yb}$ (middle REE to heavy REE) signifying enrichment along with melting in the shallow mantle (Fig. 3.12).

A coarse-grained gabbroic sample (sample 13-WJA-C028-A2) which is used for $\mathrm{U}-\mathrm{Pb}$ age determination in Chapter 4 was collected from the exposed top of a $>50 \mathrm{~m}$ sill 
and plots in the basaltic andesite field using this scheme. The evolved nature of the gabbro likely reflects within-sill crystal settling processes whereby mafic minerals settle to the base of the sill, resulting in silica enrichment as well as enrichment of plagioclase and presence of free-quartz in trace amounts of the upper portion rather than injection of a wholly more evolved magma into the sedimentary sequence.

Differences in other trace-element ratios and isotopic signatures between the intrusive rocks of South Fiord and the Isachsen Formation lavas (described below) are a reflection of different chemical evolutionary processes within each suite. We discuss examples of such divergent chemical trajectories below based on the results we presented previously (e.g. $\mathrm{Ba} / \mathrm{Nb}, \mathrm{Ba} / \mathrm{Th}$ ), in order to elucidate potential magmatic source and crustal assimilation differences.

Based on our results, we observe that the trace element and isotopic compositions of the South Fiord intrusions are distinct from those of the Isachsen Formation (e.g. Figs. 3.10, 3.11, $3.15 \&$ 3.16). This is consistent with the Strand Fiord Formation being stratigraphically younger than the Isachsen Formation (Embry and Osadetz, 1988) and that these represent two distinct magmatic pulses, possibly from different sources, depths and degrees of partial melting. Furthermore, the chemistry of South Fiord intrusions suggests that they were likely feeders for the Strand Fiord Formation lavas (Jowitt et al., 2014).

The ratio $\mathrm{Tb} / \mathrm{Yb}$ normalized to primitive mantle values $(\mathrm{McD}$ onough and Sun, 1995, symbolized as $\mathrm{Tb} / \mathrm{Yb}_{\mathrm{N}}$ ) is used to elucidate depth of partial melt (Wang et al., 2002) along with $\mathrm{Gd} / \mathrm{Yb} . \mathrm{Tb} / \mathrm{Yb}_{\mathrm{N}}>1.8$ are interpreted to signify melting of the mantle within the garnet stability field, deeper than $\sim 75 \mathrm{~km}$ whereas $\mathrm{Tb} / \mathrm{Yb}_{\mathrm{N}}<1.8$ signify 
melting in the shallower $(<75 \mathrm{~km})$ spinel lherzolite field, although values close to 1.8 likely melted both garnet and spinel lherzolitic components (Wang et al., 2002). The South Fiord intrusive rocks along with Strand Fiord Formation lavas using $\mathrm{Tb} / \mathrm{Yb}_{\mathrm{N}}$ suggest melting in the shallow mantle less than $75 \mathrm{~m}$ at depth whereas higher $\mathrm{Tb} / \mathrm{Yb}_{\mathrm{N}}$ in some Isachsen Formation lavas suggest melting at a wider range of depths, approaching the garnet stability field (Fig. 3.10).

In Figure 3.11, both the South Fiord intrusives and Isachsen Formation lavas have low $\mathrm{Gd} / \mathrm{Yb}$ indicative of shallow melting in the spinel stability field, but there is a subpopulation of Isachsen Formation lavas that has slightly higher $\mathrm{Gd} / \mathrm{Yb}$ ratios indicating that a portion of Isachsen magmatism may have formed in the garnet stability field, much like what was shown in Figure 3.10 with $\mathrm{Tb} / \mathrm{Yb}_{\mathrm{N}}$. Furthermore, a wider range of $\mathrm{La} / \mathrm{Sm}$ values in South Fiord intrusions along with Strand Fiord Formation lavas when compared to Isachsen Formation lavas suggests a common enrichment trend (Fig. 3.11). The elevated $\mathrm{La} / \mathrm{Sm}$ may be related to initial enrichment of the source in LREE, crustal assimilation, or varying degrees of partial melting. The South Fiord intrusive rocks, along with the Strand Fiord Formation lavas, show a strong correlation of decreasing Ni with lower $\mathrm{MgO}$ suggestive of strong olivine fractionation in both suites. Olivine fractionation, however, is not as important in the evolution of Isachsen Formation lavas since no correlation of $\mathrm{MgO}$ with $\mathrm{Ni}$ is observed (Fig. 3.14). We propose, based on trace and isotopic data, that South Fiord intrusive rocks likely originated from a more chemically homogenous mantle source than that of the Isachsen Formation lavas, a conclusion that also is evident in the isotopic data from Estrada and Henjes-Kunst (2004). Based on heavy and light REE slopes (Fig. 3.12), we suggest that the Isachsen Formation 
lavas may have been sourced from a wider range in depths with varying degrees of isotopic enrichment than the South Fiord intrusive rocks. Finally, the trend of decreasing $\mathrm{Mg \#}$ with decreasing $\varepsilon \mathrm{Nd}_{\mathrm{t}}$ for the South Fiord intrusions (Fig. 3.18) suggest strongly that the apparent errorchron (Fig. 3.14) of the South Fiord intrusions is instead a mixing line between a parental magma with relatively high $\varepsilon \mathrm{Nd}$, and a contaminant with lower $\varepsilon \mathrm{Nd}$. We now turn to understanding (1) what might have caused heterogeneity within the mantle source(s) for the HALIP magmas and mantle processes and (2) the particulars of potential crustal assimilation.

\subsubsection{Mantle plume head as the driver for the HALIP:}

We suggest that the source material for the Isachsen Formation lavas and the South Fiord intrusives was the upper mantle under the influence of a mantle plume head. We base this interpretation on three factors: (1) both South Fiord intrusions and Isachsen Formation lavas have lower $\varepsilon N d$ than MORB; (2) the presence of a giant dyke swarm of Cretaceous age extending $\sim 900 \mathrm{~km}$ in a radiating pattern from a focal point at the southernmost extent of the Alpha Ridge just northeast of Ellesmere Island (Buchan and Ernst, 2013), along with tectonically reconstructed portions of the radiating pattern in Svalbard and Franz Josef Land after closure of the Nansen-Gakkel Ridge (Buchan and Ernst, 2006); and (3) sedimentary evidence in the form of regional unconformities in Svalbard which suggest Cretaceous domal uplift towards the Alpha Ridge (Maher, 2001) as well as southward prograding Barremian clinoforms on the Barents Shelf (Polteau et al., 2016) that also indicate regional domal uplift, a phenomenon associated with plume head impingement (e.g. Rainbird and Ernst, 2001). 


\subsubsection{Crustal assimilation}

We next investigate the potential role of crustal assimilation and if so, which potential packages of crustal material most strongly modified the chemistry of the magmas. One way of investigating the role of crustal assimilation is by plotting Mg\# vs. $\varepsilon \mathrm{Nd}_{\mathrm{t}}$. As Figure 3.18 shows, the intrusive rocks from South Fiord show a strong positive correlation between $\mathrm{Mg} \#$ and $\varepsilon \mathrm{Nd}_{\mathrm{t}}$. This in concert with higher $\mathrm{Th} / \mathrm{La}$ (to be discussed in the next section) with lower $\varepsilon \mathrm{Nd}_{\mathrm{t}}$ appears to suggests that assimilation of crustal material played a role in modulating the magma chemistry for these South Fiord intrusions while greater scatter in the Isachsen Formation lava data suggests a less straight forward process.

Figure 3.18 (next page): $\mathrm{Mg \#}$ vs $\varepsilon N d_{t}$ diagram showing crustal influence in South Fiord intrusives and the Isachsen Formation lavas. With the exception of the chemically evolved gabbro (circled; Mg\# 0.2; sample 13-WJA-C028A2), all South Fiord intrusive analyses show a clear and fairly cohesive correlation of lower $\varepsilon \mathrm{Nd}(\mathrm{t})$ with more chemically evolved rocks (lower Mg\#). This trend suggests that mixing with crust is an important factor in the evolution of these magmas. A similar trend exists with the Isachsen Formation lavas but with much greater scatter. Dashed arrow represents approximated trend of crustal contamination. 


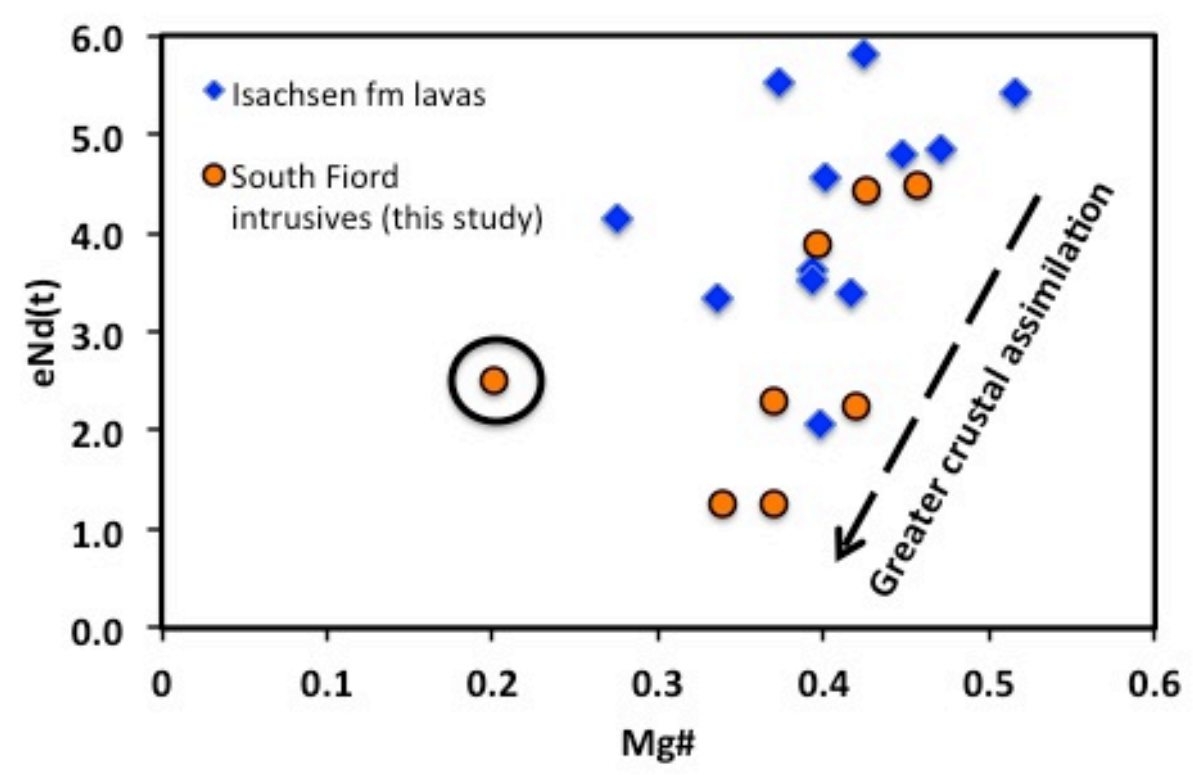

\subsubsection{Crustal assimilation modeling assumptions}

Crustal assimilation appears to have had major influence in the chemical evolution of South Fiord intrusive rocks and minor influence in the Isachsen Formation lavas. We next turn our attention to understanding the degree to which the chemical evolution of the intrusive rocks from South Fiord and the Isachsen Formation lava samples from South Fiord, Camp Five Creek and Geodetic Hills is controlled by interaction with the continental crust. As part of this section, we employ two-component modeling with an E-MORB end member and three possible crustal components as specified below.

In the $\mathrm{Nb} / \mathrm{Y}$ vs $\mathrm{Th} / \mathrm{Yb}$ classification diagram (Pearce, 2008), all samples plot above the E-MORB component of the diagonal N-MORB - OIB basalt array (Fig. 3.9B). On this basis we assume that the parental melt had chemical and Sm-Nd isotopic characteristics that, if no lithospheric interaction had occurred, would be similar to modern E-MORB. Sm-Nd isotopic assumptions are based on the arithmetic mean of samples identified as E-MORB (Waters et al., 2011). Trace element concentrations and 
all calculated trace element ratios are based on average E-MORB values (Sun and McDonough, 1989).

Magmas ascribed to the HALIP ascended through three chemically and isotopically heterogeneous packages of crustal material. The basement of Canada's Arctic islands consists of Archean- Proterozoic metasedimentary and metavolcanic rocks that, in northern Ellesmere Island, constitute the Pearya terrane (Trettin, 1987; Malone, 2012). Lying unconformably above the cratonic basement is the Cambrian - Devonian Franklinian mobile belt with sediments derived from underlying cratonic ( $>450 \mathrm{Ma})$ as well as Caledonian sources from the northeast $(<450 \mathrm{Ma})$ on the basis of $\mathrm{Nd}$ and trace element geochemistry (Patchett et al., 1999). The final package is the sedimentary sequence of the intracratonic Carboniferous - late Cretaceous Sverdrup Basin (Embry and Beauchamp, 2008).

Whereas geochemical data strongly suggest that crustal assimilation has chemically modified the composition of intrusive magmas from South Fiord as well as, but to a lesser extent, Isachsen Formation lavas, it is important to establish the level(s) within the crustal column where the assimilation occurred. Taking Sm-Nd isotopic and trace-element data from the Sverdrup Basin (Patchett et al., 2004) and the underlying Franklinian Mobile Belt (Patchett et al., 1999), the latter which represents a proxy for the cratonic basement for those sedimentary rocks older than $450 \mathrm{Ma}$, a calculation of a weighted average of the compositions of (a) the Sverdrup Basin, (b) the Franklinian Mobile Belt and (c) the underlying Archean - Proterozoic shield was made, (details in Appendix 4). A detailed methodology of these calculations and the result thereof may be found in Appendix 4 herein. Because of the paucity of S-type granites in Canada's High 
Arctic and noting that sedimentary rocks older than $~ 450$ Ma from the Franklinian mobile belt show shield-like chemical and isotopic signatures, it is assumed that these signatures were derived from the cratonic sources and thus, represent a best-case "fit" for the chemical nature of the underlying craton owing to erosive and deposition processes from disparate source regions.

\subsubsection{Two-component mixing}

Three trace element ratios that can be used to elucidate the degree of crustal involvement are $\mathrm{Th} / \mathrm{La}, \mathrm{Ba} / \mathrm{Nb}$ and $\mathrm{Nb} / \mathrm{U}$. Thus we plot each of these ratios against $\varepsilon \mathrm{Nd}_{\mathrm{t}}$ and, through two-component modeling, we use these plots in order to understand which first-order crustal package (Sverdrup Basin, Franklinian Mobile Belt and/or cratonic basement, \pm subducted sediments) had the greatest influence in chemically altering magma with a probable E-MORB starting composition.

$\mathrm{Th} / \mathrm{La}$ is a useful first-order discriminant in the level of crustal involvement in that $\mathrm{Th} / \mathrm{La}$ in oceanic rocks is $<<0.1$, but in continental crust is $\sim 0.3$ with some marine sediments up to $\sim 0.4$ (Plank, 2005). In Th/La v. $\varepsilon \mathrm{Nd}_{\mathrm{t}}$ space, both the South Fiord intrusives and Isachsen Formation lavas display a wide variance in $\mathrm{Th} / \mathrm{La}(0.13-0.21)$ and have largely overlapping chemical trajectories (Fig. 3.19). In this chemical space, the South Fiord intrusives follow most closely the Sverdrup Basin mixing curve (where assimilation of up to $20 \%$ is modeled). The trend of the Isachsen Formation lavas also tends to follow the Sverdrup Basin mixing line. Conversely, the South Fiord intrusives and Isachsen Formation lavas diverge most strongly from the cratonic mixing curve, suggesting little cratonic involvement. 


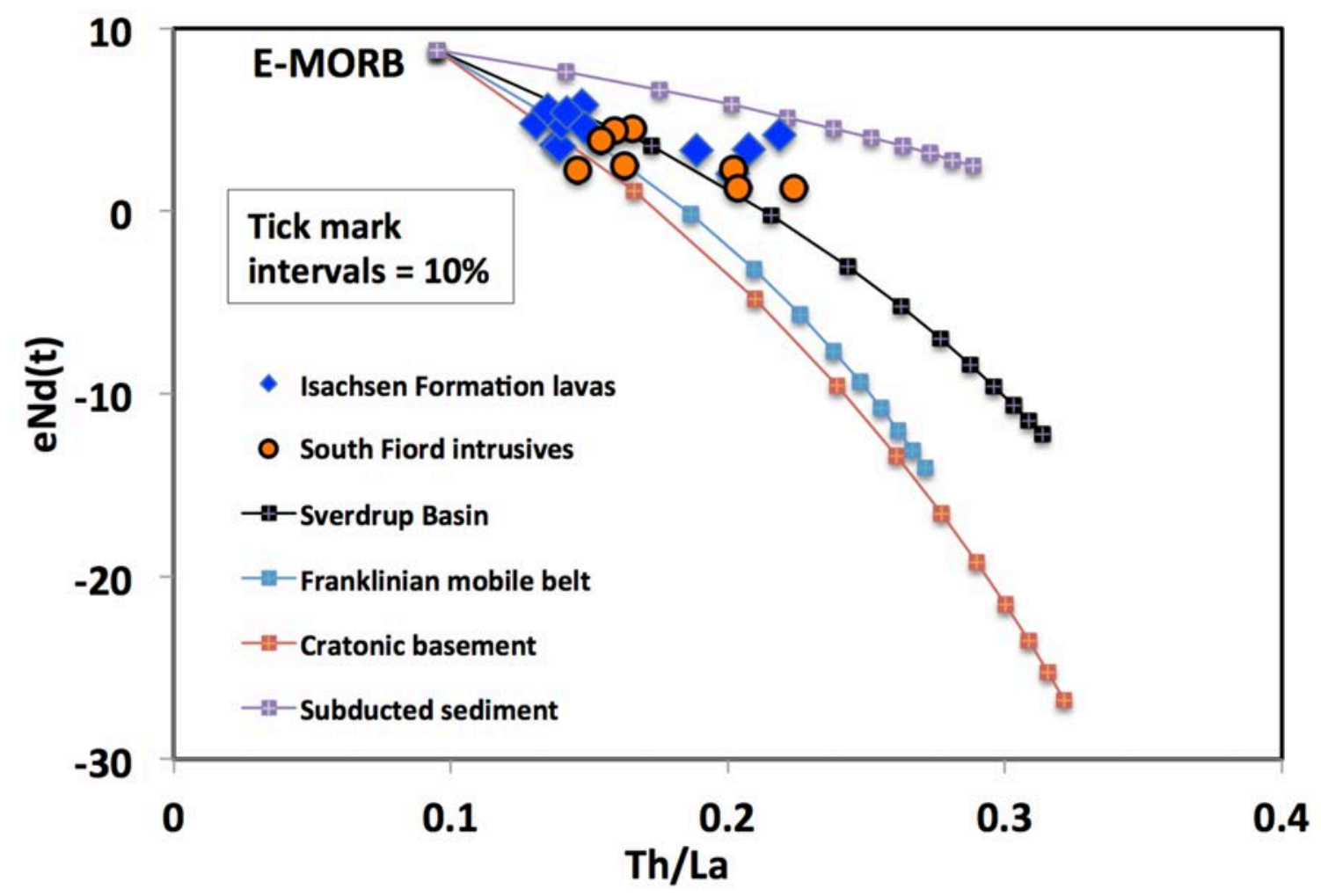

Figure 3.19: Two component mixing curves in $\mathrm{Th} / \mathrm{La} v s \mathrm{eNd}$ plot. Mixing curves connect an assumed E-MORB parent with possible crustal assimilants along with subducted sediment mixing. In this plot, both Isachsen Formation lavas and South Fiord intrusive rocks most closely follow Sverdrup basin curve. Discussion about the subducted sediment model can be found in the text. EMORB Sm-Nd data are from (Waters et al., 2011) and the E-MORB trace element composition is from Sun and McDonough (1989). Sverdrup basin crustal data weighted averages were calculated from Patchett et al. (2004), and the same for Franklinian mobile belt and cratonic data from (Patchett et al., 1999). Subducted sediment data were calculated from Plank and Langmuir (1998). Tick intervals in evolution curves are $10 \%$.

A second plot that can be used to understand the role of crustal assimilation is $\mathrm{Nb} / \mathrm{U}$ vs. $\varepsilon \mathrm{Nd}_{\mathrm{t}}$ (Fig. 3.20). Here, both the South Fiord intrusives and the Isachsen Formation lavas, again, overlap substantially (much like in the Th/La system) and range in $\mathrm{Nb} / \mathrm{U}$ from 10 - 30 with no correlation between $\varepsilon \mathrm{Nd}_{\mathrm{t}}$ and $\mathrm{Nb} / \mathrm{U}$. Two component mixing models show that the HALIP data closely follow the Sverdrup Basin curve as well as the Franklinian mobile belt curve, suggesting that $\sim 10 \%$ of crustal material was 
assimilated. Again, like the Th/La data (Fig. 3.19), there is a strong divergence between the data and the cratonic mixing curve, further confirming that cratonic basement did not play any significant role as an assimilant in the HALIP magmas (see also previous paragraph).

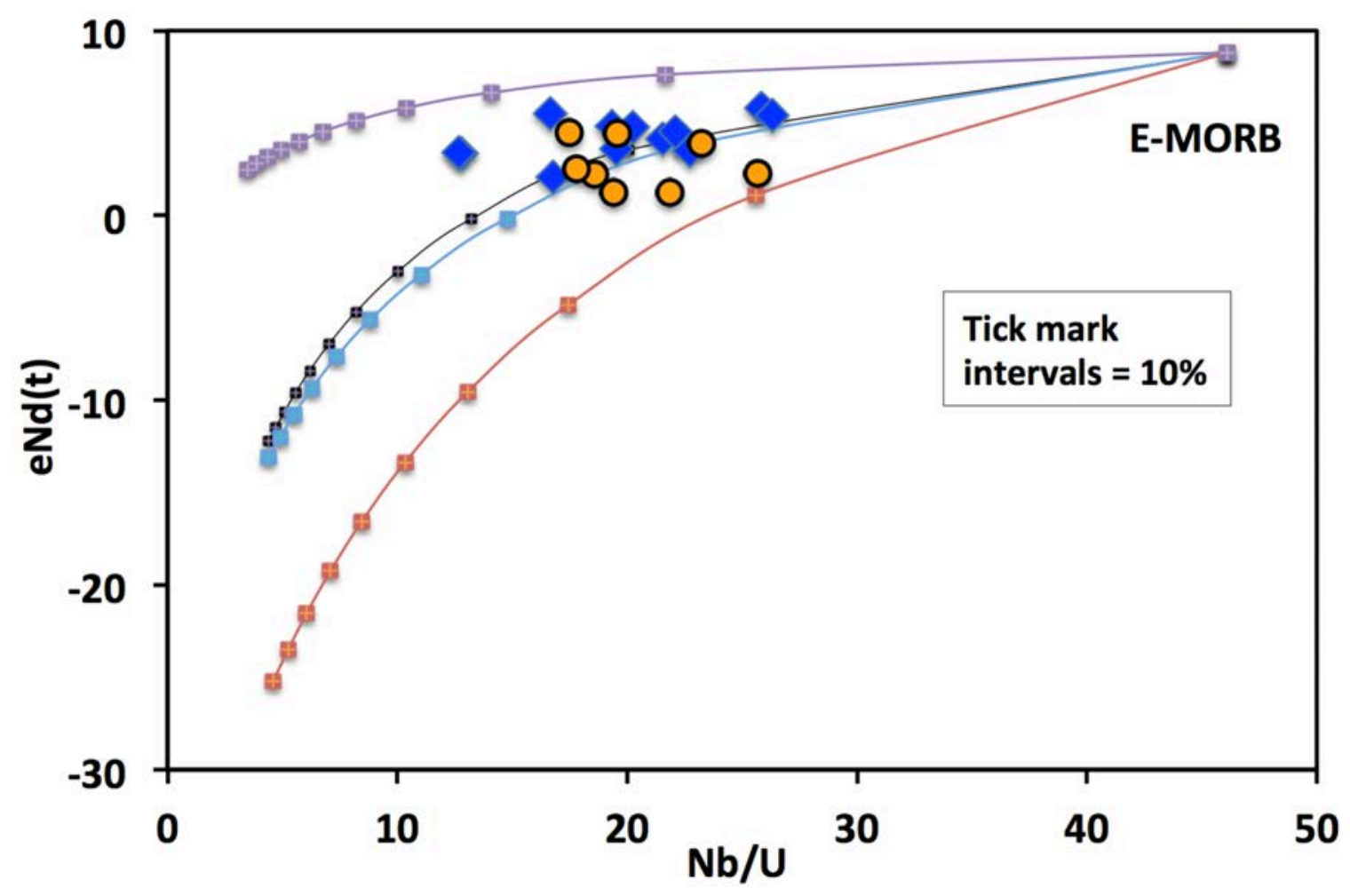

Figure 3.20: Two component mixing curves in $\mathrm{Nb} / \mathrm{U}$ vs $\varepsilon N d_{t}$ plot. In this plot, both Isachsen Formation lavas and South Fiord intrusive rocks are consistent with Sverdrup Basin and/or Franklinian mobile belt curves, but are not consistent with mixing with cratonic basement. Discussion about subducted sediment mixing can be found in the text. Mixing line colours and data symbols along with data sources are identical to those in Figure 3.19 .

One trace element ratio in which the South Fiord intrusives diverge strongly from that of the Isachsen Formation lavas is $\mathrm{Ba} / \mathrm{Nb}$ (Fig. 3.21). Whereas the South Fiord suite has $\mathrm{Ba} / \mathrm{Nb}$ values of $8-11$, the Isachsen Formation lavas display a much wider range in values $(0.8-37)$. Furthermore, in a $\mathrm{Ba} / \mathrm{Nb}$ vs. $\varepsilon \mathrm{Nd}_{\mathrm{t}}$ plot, the South Fiord intrusives show 
a tight, strongly negative correlation between $\varepsilon \mathrm{Nd}_{\mathrm{t}}(+1.2-+4.5)$ and $\mathrm{Ba} / \mathrm{Nb}$. The

Isachsen Formation lavas, on the other hand, show increasing $\mathrm{Ba} / \mathrm{Nb}$ with no systematic change in $\varepsilon \mathrm{Nd}_{\mathrm{t}}$ commensurate with the trace element ratio increase.

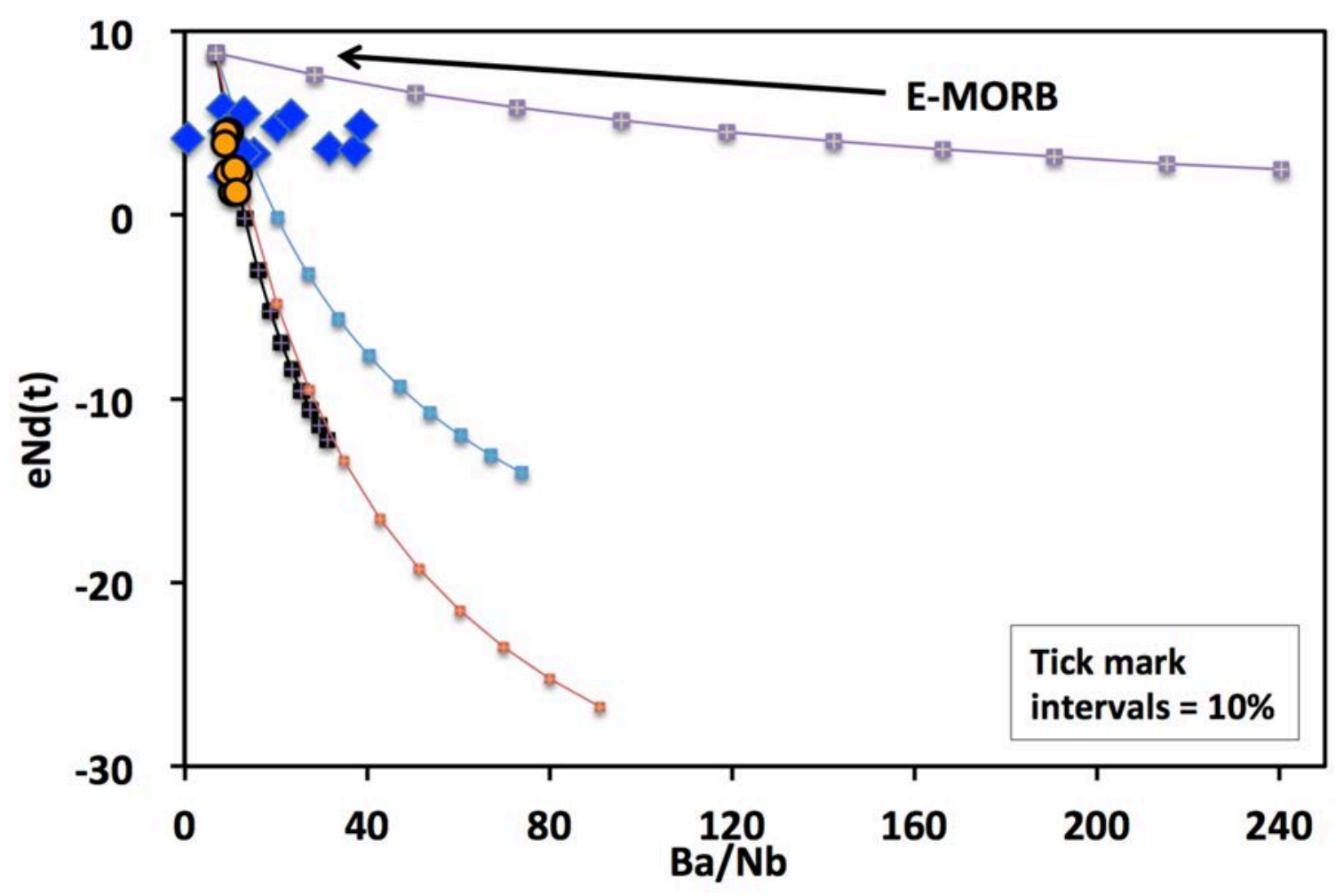

Figure 3.21: Two component mixing curves in $\mathrm{Ba} / \mathrm{Nb}$ vs $\varepsilon \mathrm{Nd}_{t}$ plot. In this plot, South Fiord Intrusive rocks show a clear mixing trend involving Sverdrup Basin crustal material whereas Isachsen Formation lavas appear to be primarily affected by a heterogenous source defined in part by incorporation of subducted sediments. Mixing line colours and data symbols along with data sources are identical to those in Figure 3.19.

In our modeling, the negative $\mathrm{Ba} / \mathrm{Nb}$ and $\varepsilon \mathrm{Nd}_{\mathrm{t}}$ correlation displayed by the South Fiord intrusives follows the mixing curves that connect E-MORB with both Sverdrup and cratonic basement, signifying that the Sverdrup Basin and/or cratonic basement rocks are likely candidates for assimilation. Owing to the shallower model path connecting EMORB with the Franklinian mobile belt, the Franklinian rocks likely did not play a substantial role in the chemical evolutionary pathway of the South Fiord intrusives. The 
apparent assimilation by South Fiord intrusive rocks of Franklinian mobile belt rocks seen in $\mathrm{Nb} / \mathrm{U}$ is more likely a function of Sverdrup Basin and Franklinian mobile belt model pathways sharing essentially identical trajectories. The Isachsen Formation lavas display a chemical trend that diverges significantly from the chemical evolution curves involving the three crustal packages, suggesting little crustal assimilation overall.

\subsubsection{Crustal interaction levels}

Taking in the above two component modeling using $\mathrm{Th} / \mathrm{La}, \mathrm{Ba} / \mathrm{Nb}$ and $\mathrm{Nb} / \mathrm{U}$ (Figs. 3.17- 19), it seems that the first-order crustal package that played the greatest role as a contaminant for South Fiord intrusives is sedimentary rocks from the Sverdrup Basin. In both $\mathrm{Th} / \mathrm{La}$ and $\mathrm{Nb} / \mathrm{U}$ vs. $\varepsilon \mathrm{Nd}_{\mathrm{t}}$ plots (Figs. $3.19 \& 3.20$ ), the modeled curve from E-MORB to cratonic values diverge significantly from the trend of both the Isachsen Formation lavas and the South Fiord intrusives. Although the South Fiord intrusives appear to follow both the Sverdrup Basin and cratonic tie-lines in $\mathrm{Ba} / \mathrm{Nb}$ space (Fig. 3.21), the Sverdrup Basin and the cratonic curves essentially overlap. The importance of Sverdrup Basin rocks supports the idea that magma storage prior to any associated eruptive events occurred within the shallow continental crust, above the level of both Franklinian and cratonic rocks.

We now turn our attention to explaining the independence of the Isachsen Formation lavas from the three first-order packages of crustal material in $\mathrm{Ba} / \mathrm{Nb}$ space (Fig. 3.21). Subducted sediments are heavily enriched in Ba that, in the case of the modern Aleutian Arc as an example, is the result of Ba precipitates and crusts derived from Ba-rich fluids from cold seeps (Suess et al., 1998) whereas the continental crust is a 
Th reservoir (Plank and Langmuir, 1998; Plank, 2005). Therefore the ratio Ba/Th may be used in part to discriminate between effects from crustal involvement and possible influences from subducted sediments. We propose the following two hypotheses to explain evolution of Isachsen Formation Lavas: (1) that the plume head which fed Isachsen Formation lavas incorporated sediments transported to the mantle from subductions zones ancestral to the present-day Aleutian and Alaska subduction zones and (2) that Isachsen Formation lavas may also have interacted with evaporite diapirs of the Otto Fiord Formation.

\subsubsection{Subducted sediment as a driver for mantle heterogeneity?}

As mentioned above, based on trace element and isotopic parameters, a heterogeneous mantle is invoked for the Isachsen Formation magmas. What might have been the cause of this heterogeneity? Based on time-integrated tomographic modeling, multiple north-verging paleo-subduction zone fronts have been hypothesized to have existed beneath Canada's Arctic Islands (Shephard et al., 2013, 2014). An issue to address here is whether there is evidence to suggest the chemistry of magmas feeding either the South Fiord intrusions (which we suggest is linked with the younger Strand Fiord Formation lavas) or the older Isachsen Formation lavas, were affected by subducted sediment in the upper mantle.

In Figure 3.15, as well as stated in the results section, both E-MORB and Sverdrup Basin sedimentary rocks have $\mathrm{Ba} / \mathrm{Th}$ ratios of 95, and 40, respectively (Sun and McDonough, 1989; Patchett et al., 2004). Whereas a population of Isachsen Formation lavas plot close to the values of E-MORB and Sverdrup Basin sedimentary rocks, a 
number of samples plot significantly higher than these (up to $\mathrm{Ba} / \mathrm{Th}=220$ ). Therefore, magmas which fed Isachsen Formation lavas must have drawn $\mathrm{Ba}$ from a chemical reservoir other than continental crust or direct melt of an E-MORB composition. We therefore propose the mantle plume head intersected a batch of sediment entrained in the mantle in extinct subduction zones. In terms of certain ocean island basalts (from Gough Island, for example), $\mathrm{Ba} / \mathrm{Th}$ along with $\mathrm{Ba} / \mathrm{Nb}$ are significantly higher when compared with data from Ascension, St. Helena, Bouvet and Tristan da Cunha islands, and Weaver et al. (1986) uses this to in part, suggest that Gough Island magmas incorporated small amounts of ancient subducted sediment. Furthermore, certain lavas in Hawai'i also show evidence of small degrees of subducted carbonate-rich sediment (Huang et al., 2009; Huang et al., 2011).

In contrast with the Isachsen Formation samples, those from the South Fiord intrusives and lavas (Jowitt et al., 2014) have uniformly low $\mathrm{Ba} / \mathrm{Nb}$ and $\mathrm{Ba} / \mathrm{Th}$, and with respect with $\mathrm{Ba} / \mathrm{Th}$, plot between E-MORB and Sverdrup Basin sedimentary rocks possibly suggesting that these rocks did not incorporate entrained ancient subducted sediment but rather have the signature of upper crustal contamination by sedimentary rocks.

For the purposes of modeling subducted sediment, we use the closest modern subduction zone to Axel Heiberg Island, the Alaska - Aleutian subduction zone, located about 3,000 km to the west-northwest. For modeling purposes, we take the relevant Sm$\mathrm{Nd}$ along with $\mathrm{Ba}, \mathrm{Nb}$, and Th concentration data from the "Aleut" and "Alaska" dataset from (Plank and Langmuir, 1998) and apply a weighting equal to the length of each arc as a percentage of the combined length of the two arcs. 
Figure $3.21\left(\mathrm{Ba} / \mathrm{Nb}\right.$ vs. $\left.\varepsilon \mathrm{Nd}_{\mathrm{t}}\right)$ shows that the trend of the Isachsen Formation lavas is not consistent with crustal assimilation models. Isachesen Formation lavas thus require a potential assimilant that remains within approximately five time-integrated epsilon $\mathrm{Nd}$ units from chondritic values. Our trench-length-weighted average $\varepsilon \mathrm{Nd}_{\mathrm{t}}$ for Aleutian and Alaska subduction zones is $\sim+2.5$. This, coupled with our weighted average $\mathrm{Ba} / \mathrm{Nb}$ (Plank and Langmuir, 1998) of 240 make an plausible mixing line describing the chemical behavior of the Isachsen Formation lavas. Furthermore, Figure 3.15 shows that a substantial number of samples from the Isachsen Formation have $\mathrm{Ba} / \mathrm{Th}$ ratios substantially higher than that of E-MORB and Sverdrup Basin sedimentary rocks, necessitating a source other than E-MORB or Sverdrup Basin crust to explain these high ratios. Based on a weighted average of the modern Aleutian and Alaska arcs (Plank and Langmuir, 1998) the $\mathrm{Ba} / \mathrm{Th}$ and $\mathrm{Ba} / \mathrm{Nb}$ ratios are 356 and 0.29 , respectively. This $\mathrm{Ba} / \mathrm{Th}$ ratio is substantially higher than for E-MORB and Sverdrup Basin sedimentary rocks as shown above. Simple two component modeling between E-MORB and the weighted average of subducted sediments on a $\mathrm{Ba} / \mathrm{Nb}$ vs. Ba/Th plot (Fig. 3.20) shows that a substantial number of Isachsen Formation lavas follow the mixing curve between the two end-members and therefore require addition of subducted sediments of up to $10 \%$. Our major assumption in constructing the subducted sediment mixing model is that the $\mathrm{Ba} / \mathrm{Nb}, \mathrm{Ba} / \mathrm{Th}$ and time-integrated $\mathrm{Sm}-\mathrm{Nd}$ isotopic composition that have been compiled for the Aleutian and Alaska subduction zones (Plank and Langmuir, 1998) remained essentially constant from 200 Ma to the present-day in the north Pacific Ocean (Shephard et al., 2013). Figure $3.21\left(\mathrm{Ba} / \mathrm{Nb}\right.$ vs $\left.\varepsilon \mathrm{Nd}_{\mathrm{t}}\right)$ and Figure $3.20(\mathrm{Ba} / \mathrm{Nb}$ vs. Ba/Th) show that the Isachsen Formation lavas follow the mixing curve between E-MORB and 
the weighted average of the Aleutian and Alaska subducted sediment compositions.

However, the South Fiord intrusives do not follow this trend. Thus, Isachsen Formation magmas may have included a subducted sediment component whereas the South Fiord intrusive magmas did not.

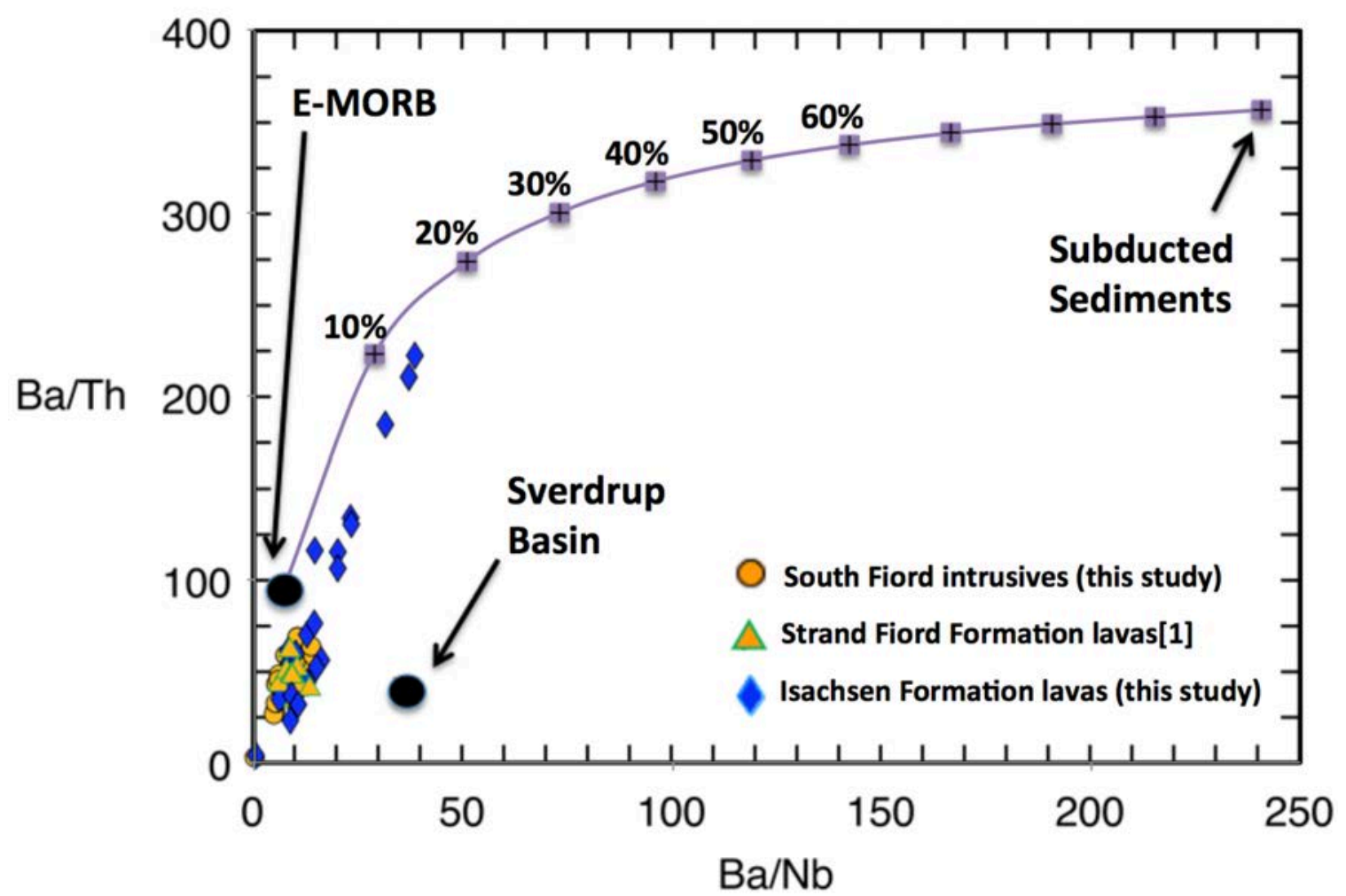

Figure 3.22: Two-component mixing curve between E-MORB and subducted sediments in $\mathrm{a} \mathrm{Ba} / \mathrm{Nb}$ vs $\mathrm{Ba} / \mathrm{Th}$ plot. The E-MORB point derived from Sun and McDonough (1989), the Sverdrup Basin point is a weighted average (described in the text) from Patchett et al. (2004) and the weighted average composition of Aleutian and Alaskan subducted sediments is from Plank and Langmuir (1998). Data from Strand Fiord Formation lavas are from Jowitt et al. (2014).

It has been speculated that the down-going slab imaged in tomographic models are the remains of the Farallon, Izanagi and Cache Creek slabs (depending on specific location: Shephard et al., 2013, 2014) which are precursors to the present day Juan de Fuca and Aleutian subduction zones. Based on seismic and numerical modeling, only 
about $15-30 \%$ of sediment gets accreted onto accretionary wedges at subduction zones, the balance $(70-85 \%)$ gets subducted into the Earth's interior (eg., von Huene and Scholl, 1991). Furthermore, of those sediments that get subducted, about $20 \%$ get entrained into arc magmatic systems leaving $80 \%$ of the remaining sediment being fully incorporated into the mantle (Plank and Langmuir, 1993). Thus we conservatively calculate that if $70 \%$ of sediments go down into subduction zones and that $80 \%$ of that $70 \%$ also bypassed a volcanic arc system, then slightly more than half $(\sim 55 \%)$ of sediment that encounters a subduction zone trench ultimately makes it into the mantle. Furthermore, recent geophysical modeling of subducted sediment shows that these sediments may detach from the subducting slab via a buoyant horizontal sediment plume intruding into the back-arc mantle and laterally propagate $100 \mathrm{~s}$ of $\mathrm{km}$ from the subduction front (Currie et al., 2007) thereby providing the sediment signature required for high $\mathrm{Ba} / \mathrm{Nb}, \mathrm{Ba} / \mathrm{Th}$ as well as comparatively low $\mathrm{Th} / \mathrm{La}$ for some of the Isachsen Formation lavas.

Based on the background presented in the previous paragraph, it is speculated that enroute to the base of the lithosphere, the plume head responsible for the production of early HALIP magmas intersected subducted sediments that were transported into the mantle via extinct subduction zones. This plume then scavenged Ba from the sediments at depth and subsequently transferred high-Ba material to the source region of the magmas feeding Isachsen Formation lavas. However, these sediments were not apparently intersected during the time period associated with the South Fiord intrusives.

A mechanism which may explain the lack of an apparent subducted sediment signature in the Strand Fiord mantle source posits that the sediment the mantle plume 
head initially intersected in the lead-up to erupting Isachsen Formation lavas was swept clear of the sediments by the time Strand Fiord Formation lavas began erupting. In this model, sediments could be incorporated into the ascending plume through thermal conduction, as models predict that plumes are hotter than the surrounding mantle (Campbell and Griffiths, 1990). The centre of the plume would be hot enough to interact with and assimilate subducted sediment plume in the mantle, thereby releasing $\mathrm{Ba}$ (and other large ion lithophile elements) from the sediment into the magmas which fed Isachsen Formation lavas.

\subsubsection{Alternative model of interaction with evaporite}

While trace element ratios of $\mathrm{Ba} / \mathrm{Nb}$ and $\mathrm{Ba} / \mathrm{Th}$ coupled with the two-component mixing between E-MORB and Aleutian-Alaskan subducted sediment indicates one possible mechanism regarding Isachsen Formation lavas being influenced by subducted sediments, major element analysis presented in Figures 3.6 and 3.8 shows major silica depletion in many of these same samples. This depletion could suggest that the compositional variation of these Isachsen Formation lavas may instead reflect a postemplacement alteration process affecting the lavas of the Isachsen Formation lavas but not the South Fiord intrusions and Strand Fiord Formation lavas. Furthermore, some of the Isachsen Formation samples with anomalously low silica also show high $\mathrm{Na}_{2} \mathrm{O}$ (Fig.3.8) along with high $\mathrm{CaO}$ (Fig. 3.23).

A way of explaining the Isachsen Formation chemistry with respect to this apparent large-ion-lithophile enrichment may be through interaction with evaporites derived from the Otto Fiord Formation. Much of the evaporite diapirs from the Otto Fiord 
Formation consist of anhydrite $\left(\mathrm{CaSO}_{4}\right)$ along with minor halite $(\mathrm{NaCl})$ and limestones (Nassichuk and Davies, 1980; see Chapter 1, Section 1.7 for a full discussion). If this scenario is correct, then as magmas which fed the Isachsen Formation, ascended through the crust and interacted with the evaporites, the basaltic magmas would assimilate $\mathrm{Ca}$ from the anhydrite along with $\mathrm{Na}$ from the halite, and in doing so also lose silica from the lavas. As of now it is difficult to say for certain if contamination with respect to the Otto Fiord Formation is indeed the case because, to the author's knowledge, no trace element analysis has been performed on evaporites from the Otto Fiord Formation (S. Grasby, written commun, 2015). Such an analysis would allow two-component chemical modeling to evaluate degrees of assimilation between lavas and evaporites. A detailed trace element analysis on the Otto Fiord Formation along with acid leached $\mathrm{Rb}-\mathrm{Sr}$ isotopic analysis on Isachsen Formation lavas (following the method of Cousens et al., 1993) would be necessary to more fully evaluate this hypothesis.

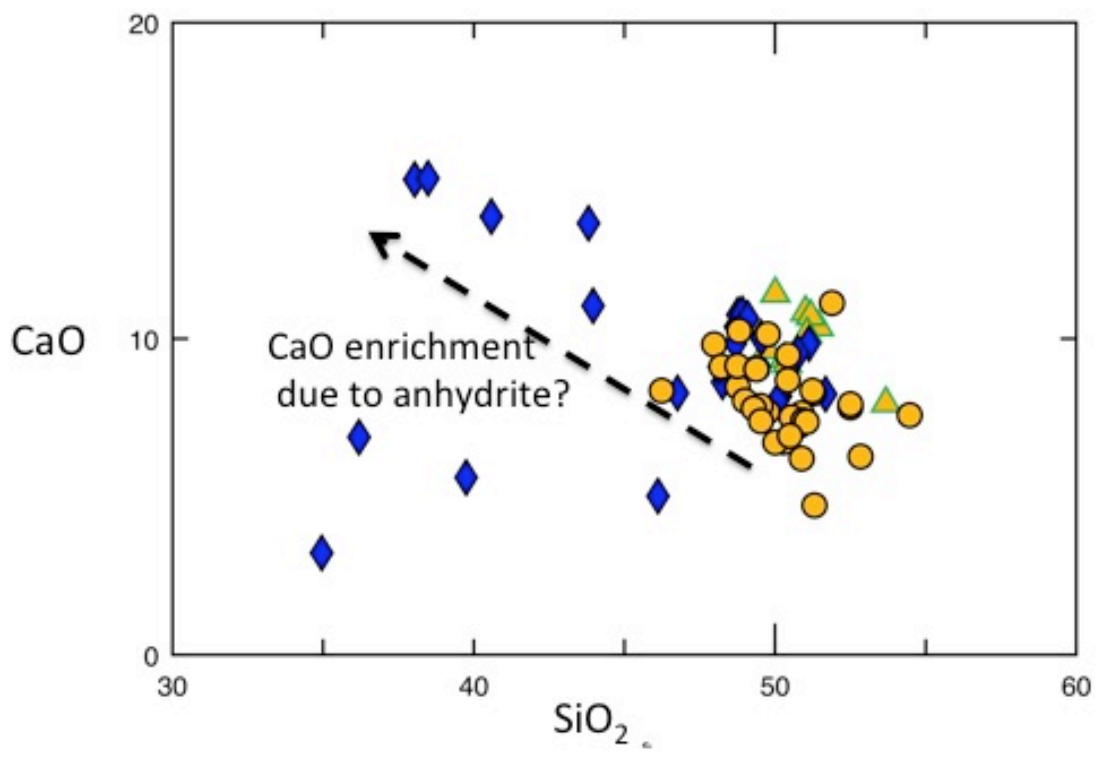

Figure 3.23: Silica versus $\mathrm{CaO}$ diagram showing that some Isachsen Formation samples that are silica-poor are enriched in $\mathrm{CaO}$. Dashed arrow marks estimated trend of assimilation of anhydrite in samples with high $\mathrm{CaO}$. 


\subsubsection{Crustal influences on Strand Fiord and Isachsen Formation lavas}

The question of why the South Fiord intrusions along with Strand Fiord Formation lavas show evidence for crustal contamination whereas lavas within the Isachsen Formation do not may have to do with the frequency of eruptions within each pulse of the HALIP. The stratigraphy of Isachsen Formation measured in Chapter 2 (Fig. 2.15) along with sections in Camp Five Creek and Geodetic Hills (both on Axel Heiberg Island) reported in Williamson (1988) shows intervening sedimentary rocks throughout the section whereas the Strand Fiord Formation lavas lack such intervening sedimentary rocks between the lava flows. This suggests that the frequency of eruptions within the Strand Fiord Formation was much greater than those within Isachsen Formation. It is thus possible that the frequency of the Strand Fiord Formation eruptions maintained an intervening thermal anomaly (causing domal uplift) affecting the sedimentary rocks of the Sverdrup Basin. This in turn, promoted crustal contamination. It is possible that Isachsen Formation eruptions were infrequent enough for a thermal anomaly to persist within the Sverdrup Basin between eruptions that would be needed for assimilation.

\subsection{CONCLUSIONS}

The South Fiord intrusions, along with Isachsen and Strand Fiord Formation lavas are mostly classified as basalts to basaltic andesites based on total alkali vs. silica systematics as well as tholeiitic on AFM systematics (LeBas et al., 1986; Irvine and Baragar, 1971). Petrographically, the characteristic mineral assemblages of these samples contain plagioclase and clinopyroxene with trace amounts of quartz in the more 
chemically evolved sample (13-WJA-C028-A2). A number of South Fiord intrusive samples along with the Isachsen Formation lavas show evidence of secondary alteration.

In terms of their trace element classifications, all samples are subalkaline basalts except for one, sample 13-WJA-C028-A2, that is basaltic andesite. New trace element and isotopic data reported herein show that the South Fiord intrusives are chemically distinct from the Isachsen Formation volcanic rocks. Furthermore, we conclude that the South Fiord intrusives likely have chemical affinities with the Strand Fiord Formation lavas. Trace-element and isotopic results indicate a homogenous upper mantle source coupled with a strong Sverdrup Basin assimilation signature for the South Fiord intrusives (matching Strand Fiord Formation lavas). Conversely, using the same plots, older Isachsen Formation lavas probably originated from a chemically heterogeneous mantle source with less crustal assimilation. It is speculated that mantle heterogeneity in the Isachsen Formation lavas is strongly defined by the interaction with a subducted sediment component (Fig. 3.21) derived from extinct, Jura-Cretaceous subduction zones (see Section 4.4). Furthermore, the potential presence of a subducted sediment signature in the Isachsen Formation lavas and the lack thereof in the South Fiord intrusives, coupled with a strong crustal assimilation signature in the South Fiord intrusives may be the result of a subducted slab impacting the Isachsen lavas. In this model, the subducting slab provides the sediments necessary for higher $\mathrm{Ba} / \mathrm{Nb}$ and especially $\mathrm{Ba} / \mathrm{Th}$. Such sediment may detach from the subducting slab and laterally propagate 100s of km into the back-arc (Currie et al., 2007) providing the sediment signature required for high $\mathrm{Ba} / \mathrm{Nb}, \mathrm{Ba} / \mathrm{Th}$ and comparatively low $\mathrm{Th} / \mathrm{La}$. It is also equally possible that the high $\mathrm{Ba} / \mathrm{Th}, \mathrm{Ba} / \mathrm{Nb}$ along with high $\mathrm{Ca}$ and $\mathrm{Na}$ in some samples of Isachsen Formation lavas 
could have been derived from interaction with evaporite diapirs from the Otto Fiord Formation. Further isotopic work (e.g. Rb-Sr) along with the trace element analyses of the Otto Fiord Formation (evaporates) will help clarify the nature of contaminants (subducted sediment vs. anhydrite interaction) discussed above with respect to the Isachsen Formation.

\subsection{CHAPTER REFERENCES}

Amundsen, H., Evdokimov, A., Dibner, V.D., and Andresen, A., 1998, Geochemistry and petrogenetic significance of Mesozoic magmatism on Franz Josef Land, northeastern Russia, in Solheim, A., Mustatov, E., and Heinz, N. eds., Geological Aspects of Franz Josef Land and the Northerenmost Barents Sea, Norsk Polarinstitutt, p. 105120.

Bailey, J.C., and Brooks, K., 1988, Petrochemistry and tectonic setting of Lower Cretaceous tholeiites from Franz Josef Land, U.S.S.R.: Bulletin of the Geological Society, v. 37, p. 31-49.

Buchan, K.L., and Ernst, R.E., 2013, Diabase dyke swarms of Nunavut, Northwest Territories and Yukon, Canada: Geological Survey of Canada Open File 7464, 2013; 24 pages (1 sheet),.

Buchan, K.L., and Ernst, R.E., 2006, Giant dyke swarms and the reconstruction of the Canadian Arctic islands , Greenland , Svalbard and Franz Josef Land, in Hanski, E., Mertanen, S., Ramo, T., and Vuollo, J. eds., Dyke Swarms - Time Markers of Crustal Evolution, Taylor \& Francis, p. 27-48.

Campbell, I.H., and Griffiths, R.W., 1990, Implications of mantle plume structure for the evolution of flood basalts: Earth and Planetary Science Letters, v. 99, no. 1-2, p. 79- 
93, doi: 10.1016/0012-821X(90)90072-6.

Cohen, K.M., Finney, S.C., Gibbard, P.L., and Fan, J.-X., 2013, The ICS International Chronostratigraphic Chart: Episodes, v. 36, p. 199-204, doi: 10.1111/j.15023931.1980.tb01026.x.

Corfu, F., Polteau, S., Planke, S., Faleide, J.I., Svensen, H., Zayoncheck, A., and Stolbov, N., 2013, U-Pb geochronology of Cretaceous magmatism on Svalbard and Franz Josef Land, Barents Sea Large Igneous Province: Geological Magazine, v. 150, no. 6, p. 1127-1135, doi: 10.1017/S0016756813000162.

Cousens, B.L., Spera, F.J., and Dobson, P.F., 1993, Post-eruptive alteration of silicic ignimbrites and lavas, Gran Canaria, Canary Islands: Strontium, neodymium, lead, and oxygen isotopic evidence: Geochimica et Cosmochimica Acta, v. 57, no. 3, p. 631-640, doi: 10.1016/0016-7037(93)90374-6.

Currie, C.A., Beaumont, C., and Huismans, R.S., 2007, The fate of subducted sediments: A case for backarc intrusion and underplating: Geology, v. 35, no. 12, p. 1111-1114, doi: 10.1130/G24098A.1.

Døssing, A., Jackson, H.R., Matzka, J., Einarsson, I., Rasmussen, T.M., Olesen, A. V, and Brozena, J.M., 2013, On the origin of the Amerasia Basin and the High Arctic Large Igneous Province -- Results of new aeromagnetic data: Earth and Planetary Science Letters, v. 363, p. 219-230.

Drachev, S., and Saunders, A., 2006, The early Cretaceous Arctic LIP: its geodynamic setting and implications for Canada Basin opening, in Scott, R.A. and Thurston, D.K. eds., Proceedings of the Fourth International Conference on Arctic Margins, Anchorage, USA. 
Embry, A.F., 2011, Chapter 36 Petroleum prospectivity of the Triassic-Jurassic succession of Sverdrup Basin, Canadian Arctic Archipelago: Geological Society, London, Memoirs, v. 35, no. 1, p. 545-558, doi: 10.1144/M35.36.

Embry, A.F., and Beauchamp, B., 2008, Chapter 13: Sverdrup Basin, in Miall, A.D. ed., Sedimentary Basins of the World: Volume 5, p. 451-471.

Embry, A.F., and Osadetz, K.G., 1988, Stratigraphy and tectonic significance of Cretaceous volcanism in the Queen Elizabeth Islands, Canadian Arctic Archipelago: Canadian Journal of Earth Sciences, vol. 25, p. 1209-1219.

Ernst, R.E., 2014, Large Igneous Provinces: Cambridge University Press, Cambridge, $\mathrm{UK}, 653 \mathrm{p}$.

Ernst, R.E., and Buchan, K.L., 2003, Recognizing mantle plumes in the geological record: Annual Review of Earth and Planetary Sciences, v. 31, no. 1, p. 469-523, doi: 10.1146/annurev.earth.31.100901.145500.

Estrada, S., and Henjes-Kunst, F., 2013, 40Ar-39Ar and U-Pb dating of Cretaceous continental rift-related magmatism on the northeast Canadian Arctic margin: Zeitschrift der Deutschen Gesellschaft für Geowissenschaften, v. 164, no. 1, p. $107-$ 130, doi: 10.1127/1860-1804/2013/0005.

Estrada, S., and Henjes-Kunst, F., 2004, Volcanism in the Canadian High Arctic related to the opening of the Arctic Ocrean: Z. dt. geol. Ges, v. 154, no. 4, p. 579-603. Evenchick, C.A., Davis, B.J., Bedard, J.H., Hayward, N., and Friedman, R.M., 2014, Ages of magmatism in the central Sverdrup Basin, Canadian Arctic Islands, from volcanigenic rocks, geochronology, and paleo-depths of saucer-shaped sills, in Geological Society of America Abstracts with Programs, p. 567. 
Evenchick, C.A., Davis, W.J., Bédard, J.H., Hayward, N., and Friedman, R.M., 2015, Evidence for protracted High Arctic large igneous province magmatism in the central Sverdrup Basin from stratigraphy, geochronology, and paleodepths of saucer-shaped sills: Geological Society of America Bulletin, p. B31190.1, doi: 10.1130/B31190.1.

Faure, G., and Mensing, T.M., 2005, Isotopes: Prinicpals and Applications: John Wiley \& Sons, Hoboken, New Jersey, 896 p.

Huang, S., Abouchami, W., Blichert-Toft, J., Clague, D.A., Cousens, B.L., Frey, F.A., and Humayun, M., 2009, Ancient carbonate sedimentary signature in the Hawaiian plume: Evidence from Mahukona volcano, Hawaii: Geochemistry Geophysics Geosystems, v. 10, no. 8, doi: 10.1029/2009GC002418.

Huang, S., Farkaš, J., and Jacobsen, S.B., 2011, Stable calcium isotopic compositions of Hawaiian shield lavas: Evidence for recycling of ancient marine carbonates into the mantle: Geochimica et Cosmochimica Acta, v. 75, no. 17, p. 4987-4997, doi: 10.1016/j.gca.2011.06.010.

von Huene, R., and Scholl, D.W., 1991, Observations at convergent margins concerning sediment subduction, subduction erosion, and the growth of continental crust: Reviews of Geophysics, v. 29, no. 3, p. 279, doi: 10.1029/91RG00969. Irvine, T.N., and Baragar, W.R. A., 1971, A Guide to the Chemical Classification of the Common Volcanic Rocks: Canadian Journal of Earth Sciences, v. 8, p. 523-548, doi: 10.1139/e71-055.

Jowitt, S.M., Williamson, M., and Ernst, R.E., 2014, Geochemistry of the 130 to $80 \mathrm{Ma}$ Canadian High Arctic Large Igneous Province (HALIP) Event and Implications for 
Ni-Cu-PGE Prospectivity: Economic Geology, v. 109, no. 2, p. 281-307.

Kingsbury, C.G., Williamson, M.-C., Day, S.J., and McNeil, R.J., 2014, The 2013

Isachsen expedition to Axel Heiberg Island, Nunavut, Canada: a field report:

Geological Survey of Canada, Open File 7539, 2014; 6 pages (1 sheet), doi: $10.4095 / 293842$.

LeBas, M.J., LeMaitre, R.W., Streckeisen, A., and Zanettin, B., 1986, A Chemical Classification of Volcanic Rocks Based on the Total Alkali-Silica Diagram: Journal of Petrology, v. 27, no. 1984, p. 745-750.

Levskii, L.K., Stolbov, N.M., Bogomolov, E.S., Vasil'eva, I.M., and Makar'eva, E.M., 2006, Sr-Nd-Pb isotopic systems in basalts of the Franz Josef Land Archipelago:

Geochemistry International, v. 44, no. 4, p. 327-337, doi:

10.1134/S0016702906040021.

Ludwig, K.R., 1991, ISOPLOT; a plotting and regression program for radiogenic-isotope data; version 2.53: U.S. Geological Survey Open File Report 91-445, p. 39.

Maher, H.D., 2001, Manifestations of the Cretaceous High Arctic Large Igneous Province in Svalbard: The Journal of Geology, v. 109, no. 1, p. 91-104, doi: 10.1086/317960.

Malone, S.J., 2012, Tectonic evolution of northern Ellesmere Island : insights from the Pearya Terrane , Ellesmerian Clastic Wedge And Sverdrup Basin: Ph.D. thesis, University of Iowa, Iowa City, 276 p.

Marzoli, A., 1999, Extensive 200-Million-Year-Old Continental Flood Basalts of the Central Atlantic Magmatic Province: Science, v. 284, no. 5414, p. 616-618, doi: 10.1126/science.284.5414.616. 
McDonough, W.F., and Sun, S. -s., 1995, The Composition of the Earth: Chemical Geology, v. 120, p. 223-253.

Milner, S.C., Duncan, A.R., Whittinham, A.M., and Ewart, A., 1995, Trans-Atlantic coorelation of eruptive sequences and individual silicic volcanic units within the Parana - Etendeka igneous province: Journal of Volcanology and Geothermal Research, v. 69, p. 137-157.

Nassichuk, W.W., and Davies, G.R., 1980, Stratigraphy and sedimentation of the Otto Fiord formation - a major Mississippian-Pennsylvanian evaporite of subaqueous origin in the Canadian Arctic Archipelago, in Irish, E.J.W. ed., Geological Survey of Canada Bulletin 286, Ottawa, ON, p. 87.

Nejbert, K., Krajewski, K.P., Dubinska, E., and Pécskay, Z., 2011, Dolerites of Svalbard, north-west Barents Sea Shelf: age, tectonic setting and significance for geotectonic interpretation of the High-Arctic Large Igneous Province: Polar Research, v. 30, p. 1-24, doi: 10.3402/polar.v30i0.7306.

Patchett, P.J., Embry, A.F., Ross, G.M., Beauchamp, B., Harrison, J.C., Mayr, U., Isachsen, C.E., Rosenberg, E.J., and Spence, G.O., 2004, Sedimentary Cover of the Canadian Shield through Mesozoic Time Reflected by Nd Isotopic and Geochemical Results for the Sverdrup Basin, Arctic Canada: The Journal of Geology, v. 112, no. 1, p. 39-57.

Patchett, P.J., Roth, M.A., Canale, B.S., de Freitas, T.A., Harrison, J.C., Embry, A.F., and Ross, G.M., 1999, Nd isotopes, geochemistry, and constraints on sources of sediments in the Franklinian mobile belt, Arctic Canada: Geological Society of America Bulletin, v. 111, no. 4, p. 578-589, doi: 10.1130/0016- 
7606(1999)111<0578:NIGACO>2.3.CO;2.

Pearce, J.A., 2008, Geochemical fingerprinting of oceanic basalts with applications to ophiolite classification and the search for Archean oceanic crust: Lithos, v. 100, no. 1-4, p. 14-48, doi: 10.1016/j.lithos.2007.06.016.

Pearce, J.A., and Norry, M.J., 1979, Petrogenetic implications of Ti, Zr, Y, and Nb variations in volcanic rocks: Contributions to Mineralogy and Petrology, v. 69, no. 1, p. 33-47, doi: 10.1007/BF00375192.

Peate, D.W., 1997, The Parana-Etendeka Province, in Mahony, J.J. and Coffin, M.F. eds., Large Igneous Provinces, American Geophysical Union, Washington, DC, p. 217245.

Plank, T., 2005, Constraints from Thorium/Lanthanum on Sediment Recycling at Subduction Zones and the Evolution of the Continents: Journal of Petrology, v. 46, no. 5, p. 921-944, doi: 10.1093/petrology/egi005.

Plank, T., and Langmuir, C.H., 1998, The chemical composition of subducting sediment and its consequences for the crust and mantle: Chemical Geology, v. 145, no. 3-4, p. 325-394, doi: 10.1016/S0009-2541(97)00150-2.

Plank, T., and Langmuir, C.H., 1993, Tracing trace elements from sediment input to volcanic output at subduction zones: Nature, v. 362, no. 6422, p. 739-743, doi: 10.1038/362739a0.

Polteau, S., Hendriks, B.W.H., Planke, S., Ganerød, M., Corfu, F., Faleide, J.I., Midtkandal, I., Svensen, H.S., and Myklebust, R., 2016, The Early Cretaceous Barents Sea Sill Complex: Distribution, 40Ar/39Ar geochronology, and implications for carbon gas formation: Palaeogeography, Palaeoclimatology, Palaeoecology, v. 
441, p. 83-95, doi: 10.1016/j.palaeo.2015.07.007.

Rainbird, R.H., and Ernst, R.E., 2001, The sedimentary record of mantle-plume uplift, in Ernst, R.E. and Buchan, K.L. eds., Mantle Plumes: Their Identification Through Time, Geological Society of America Special Paper 352, p. 227-245.

Richard, P., Shimizu, N., and Allègre, C.J., 1976, 143Nd/146Nd, a natural tracer: an application to oceanic basalts: Earth and Planetary Science Letters, v. 31, no. 2, p. 269-278, doi: 10.1016/0012-821X(76)90219-3.

Senger, K., Tveranger, J., Ogata, K., Braathen, A., and Planke, S., 2014, Late Mesozoic magmatism in Svalbard: A review: Earth-Science Reviews, v. 139, p. 123-144, doi: 10.1016/j.earscirev.2014.09.002.

Shephard, G.E., Flament, N., Williams, S., Seton, M., Gurnis, M., and Müller, R.D., 2014, Circum-Arctic mantle structure and long-wavelength topography since the Jurassic: Journal of Geophysical Research: Solid Earth, v. 119, no. 1, p. 7889-7908, doi: 10.1002/2014JB011078.Received.

Shephard, G.E., Müller, R.D., and Seton, M., 2013, The tectonic evolution of the Arctic since Pangea breakup: Integrating constraints from surface geology and geophysics with mantle structure: Earth-Science Reviews, v. 124, p. 148-183, doi: 10.1016/j.earscirev.2013.05.012.

Smallwood, J.R., and White, R.S., 2002, Ridge-plume interaction in the North Atlantic and its influence on continental breakup and seafloor spreading, in Jolley, D.W. and Bell, B.R. eds., The North Atlantic Igneous Province: Stratigraphy, Tectonic, Volcanic and Magmatic Processes, Geological Society, London, p. 15-37.

Suess, E., Bohrmann, G., von Huene, R., Linke, P., Wallmann, K., Lammers, S., Sahling, 
H., Winckler, G., Lutz, R.A., and Orange, D., 1998, Fluid venting in the eastern Aleutian Subduction Zone: Journal of Geophysical Research, v. 103, no. B2, p. 2597-2614, doi: 10.1029/97JB02131.

Sun, S. -s., and McDonough, W.F., 1989, Chemical and isotopic systematics of oceanic basalts: implications for mantle composition and processes: Geological Society, London, Special Publications, v. 42, no. 1, p. 313-345, doi:

10.1144/GSL.SP.1989.042.01.19.

Tegner, C., Storey, M., Holm, P.M., Thorarinsson, S.B., Zhao, X., Lo, C.-H., and Knudsen, M.F., 2011, Magmatism and Eurekan deformation in the High Arctic Large Igneous Province: 40Ar-39Ar age of Kap Washington Group volcanics, North Greenland: Earth and Planetary Science Letters, v. 303, no. 3-4, p. 203-214, doi: 10.1016/j.eps1.2010.12.047.

Trettin, H.P., 1987, Pearya: a composite terrane with Caledonian affinities in northern Ellesmere Island: Canadian Journal of Earth Sciences , v. 24, no. 2, p. 224-245, doi: 10.1139/e87-025.

Trettin, H.P., and Parrish, R., 1987, Late Cretaceous bimodal magmatism, northern Ellesmere Island: isotopic age and origin: Canadian Journal of Earth Sciences, v. 24, p. $257-265$.

Villeneuve, M., and Williamson, M.-C., 2006, 40Ar-39Ar dating of mafic magmatism from the Sverdrup Basin Magmatic Province, in Scott, R.A. and Thurston, D.K. eds., Proceedings of the Fourth International Conference on Arctic Margins, p. 206215.

Wang, K., Plank, T., Walker, J.D., and Smith, E.I., 2002, A mantle melting profile across 
the Basin and Range, SW USA: Journal of Geophysical Research, v. 107, no. B1. Waters, C.L., Sims, K.W.W., Perfit, M.R., Blichert-Toft, J., and Blusztajn, J., 2011, Perspective on the Genesis of E-MORB from Chemical and Isotopic Heterogeneity at 9-10 N East Pacific Rise: Journal of Petrology, v. 52, no. 3, p. 565-602, doi: 10.1093/petrology/egq091.

Weaver, B.L., Wood, D.A., Tarney, J., and Joron, J.L., 1986, Role of subducted sediment in the genesis of ocean-island basalts: Geochemical evidence from South Atlantic Ocean islands: Geology, v. 14, p. 275, doi: 10.1130/00917613(1986)14<275:ROSSIT>2.0.CO;2.

White, R., and McKenzie, D., 1989, Magmatism at Rift Zones : The Generation of Volcanic Continental Margins: Journal of Geophysical Research, v. 94, no. B6, p. $7685-7729$.

Williamson, M.-C., 1988, The Cretaceous igneous province of the Sverdrup Basin, Canadian Arctic: Field relations and petrochemical studies: Ph.D. thesis, Dalhousie University, Halifax, Nova Scotia, 417 p. 


\section{Chapter 4}

\section{U-Pb Geochronology of the HALIP from Axel Heiberg Island in Nunavut, Canada: implications for magmatic evolution of the Strand Fiord formation.}

\subsection{INTRODUCTION}

\subsubsection{Chapter introduction and scope}

This chapter is focused on presenting the results of precise $\mathrm{U}-\mathrm{Pb}$ age determinations that date two intrusives which are feeders for the Strand Fiord Formation. What follows is an overview of the Strand Fiord Formation along with existing age constraints, both in terms of chronostratigraphy and analytical age determinations in addition to gaps in knowledge that this chapter seeks to fulfill.

\subsubsection{The Strand Fiord Formation}

Much of the early work in describing the Strand Fiord Formation was from Ricketts et al. (1985) and Williamson (1988), and a brief summary of this research is provided here. The Strand Fiord Formation consists of a laterally extensive package of predominantly subaerial mafic lava flows that together mark a major pulse of volcanic activity in Canada's Arctic. Individual lava flows within the Bunde Fiord section (NW Axel Heiberg Island, near Artharber Creek) are 35-60 m in thickness with the volcanic stratigraphy in total approaching close to $800 \mathrm{~m}$, marking among the thickest succession of these flows (Ricketts et al., 1985). From Bunde Fiord, moving in a SSE transect along Axel Heiberg Island's west coast, the Strand Fiord Formation lavas taper in total thickness to $285 \mathrm{~m}$ in the vicinity of Strand Fiord (150 km SSE of Bunde Fiord) and taper further to zero thickness $70 \mathrm{~km} \mathrm{SSE}$ of Strand Fiord (See Chapter 1, Fig. 1.5 for 
geographic distribution; Ricketts et al., 1985). In some stratigraphic sections in the Strand Fiord Formation, subaerial lavas constitute $>85 \%$ of the total thickness of their respective section with the remainder taken up by laharic breccia and shale interbeds (Ricketts et al., 1985). The total proportion of the lavas decreases and the percentage of breccia and shale interbeds as a whole increases dramatically along a W-E transect from the entrance of Expedition Fiord to the head of Strand Fiord (near Bastion Ridge) along the central portion of Axel Heiberg Island's west coast (Williamson, 1988; Ricketts et al., 1985).

\subsubsection{Chronostratigraphy}

As discussed in Chapter 1, based on stratigraphic position, Embry and Osadetz (1988) identified four cycles of HALIP-related volcanic activity in northern Canada (Fig. 4.1): Cycle 1 (Valanginian - early Barremian) and Cycle 2 (Late Barremian - Aptian) constitute the Paterson Island and Walker Island members of the Isachsen Formation, respectively. Cycle 3 (late Aptian - Cenomanian) is represented by the continental flood basalt stack of the Strand Fiord Formation, and lastly the late Cenomanian Maastrichtian Hansen Point volcanics constitute Cycle 4 (Embry and Osadetz, 1988). Historically, the HALIP has been divided into two broad episodes, based on chemistry: tholeiitic magmas comprise the initial phase between 130 - 80 Ma while a later alkaline phase ensued between 85 - 60 Ma (Tegner et al., 2011). In Canada, Cycles 1-3 are tholeiitic whereas Cycle 4 (the Hansen Point Volcanics) are alkaline (Embry and Osadetz, 1988). Cycle 4, which would also include the alkaline Wootton Igneous Complex on northern Ellesmere Island (Estrada and Henjes-Kunst, 2013), may be related to initial rifting that ultimately led to the formation of the Nansen-Gakkel spreading ridge and thus could be unrelated to the HALIP (Thórarinsson et al., 2015). This stratigraphic 
framework is thought to also provide a context for the intrusive component, in that the intrusive component should be linked to the volcanic rocks. However, to make the specific links between the intrusive component and the volcanic rocks requires high precision dating (particularly using the $\mathrm{U}-\mathrm{Pb}$ method), on the intrusive rocks.

Furthermore, knowing the precise intrusive ages, contributes more precise constraints on the timing of the correlated volcanic units, whose chronostratigraphic ages can have significant uncertainties

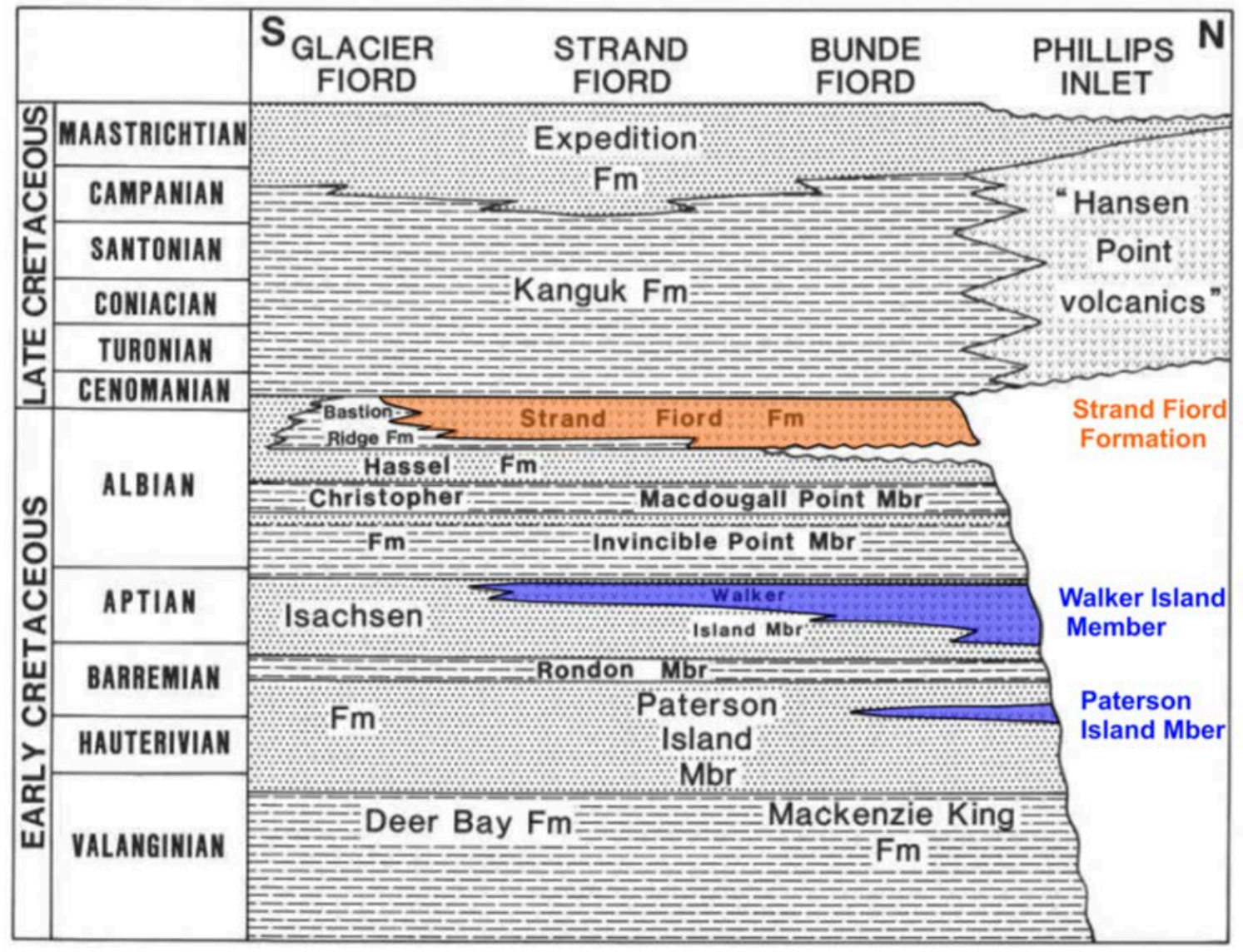

Figure 4.1: Chronostratigraphy of the Cretaceous component of the Sverdrup Basin highlighting HALIP volcanism associated with the Isachsen Formation along with the Strand Fiord Formation flood lavas. Note how the Strand Fiord Formation as drawn bisects the Cenomanian and Albian stages. Original figure from Embry and Osadetz (1988) as modified in Kingsbury et al. (2016). Location of N-S transect of this figure is shown on Figure 4.2. 


\subsubsection{Review of previous geochronology}

Initial age determinations of HALIP mafic rocks were largely $\mathrm{K}$-Ar and ${ }^{40} \mathrm{Ar} /{ }^{39} \mathrm{Ar}$ whole-rock analyses with ancillary determinations based on $\mathrm{Rb}-\mathrm{Sr}$ dating (Table 4.1). Ages from the initial pulse of the High Arctic LIP (largely commensurate with Cycles 1 and 2 of Embry and Osadetz (1988)) include a K-Ar age of 123 Ma from a dyke on Melville Island, and 131 and 152 Ma determinations (also by K-Ar) for sills intersected by borehole drilled on Sabine Peninsula, Mellvile Island (Fig. 4.2; Balkwill and Haimila, 1978). Approximately $330 \mathrm{~km} \mathrm{NE}$ of Sabine Peninsula on the Grinnell Peninsula of Devon Island, two K-Ar ages derived from dykes yield ages of $115 \pm 5 \mathrm{Ma}$ and $117 \pm 5 \mathrm{Ma}$ (Stevens et al., 1982). Both of these dykes on Sabine and Grinnell Peninsulas are from the radiating Queen Elizabeth Islands swarm, discussed in Chapter 1 of this thesis (Buchan and Ernst, 2013). On Axel Heiberg Island, $\mathrm{a}^{40} \mathrm{Ar} /{ }^{39} \mathrm{Ar}$ age from a Queen Elizabeth Island dyke near Lightfoot River yielded an age of 128.2 $\pm 2.1 \mathrm{Ma}$ (Villeneuve and Williamson, 2006). On the Eurasian side of the Arctic margin, specifically Svalbard, K-Ar age determinations of diabasic rocks yield a histogram of ages ranging from 78 $125 \mathrm{Ma}$ with a peak at $115 \mathrm{Ma}$ (Fig. 12a in Nejbert et al., 2011). Preliminary ${ }^{40} \mathrm{Ar} /{ }^{39} \mathrm{Ar}$ ages of basalts on Kong Karls Land ( $150 \mathrm{~km}$ east from mainland Svalbard) give Barremian - Albian ages which correspond with 100 - 129 Ma (Grogan et al., 2000; Cohen et al., 2013) and $\mathrm{a}^{40} \mathrm{Ar} /{ }^{39} \mathrm{Ar}$ age of $120.22 \pm 1.87 \mathrm{Ma}$ was obtained from plagioclase in a mafic sill in Svalbard (Polteau et al., 2016). On Franz Josef Land (Russia), three ${ }^{40} \mathrm{Ar} /{ }^{39} \mathrm{Ar}$ ages from a dyke, flow and sill yield $125.2 \pm 5.5,156.5 \pm 5.5$ and 189.1 \pm 11.4 Ma determinations, respectively (Koryakin and Shipilov, 2009). 


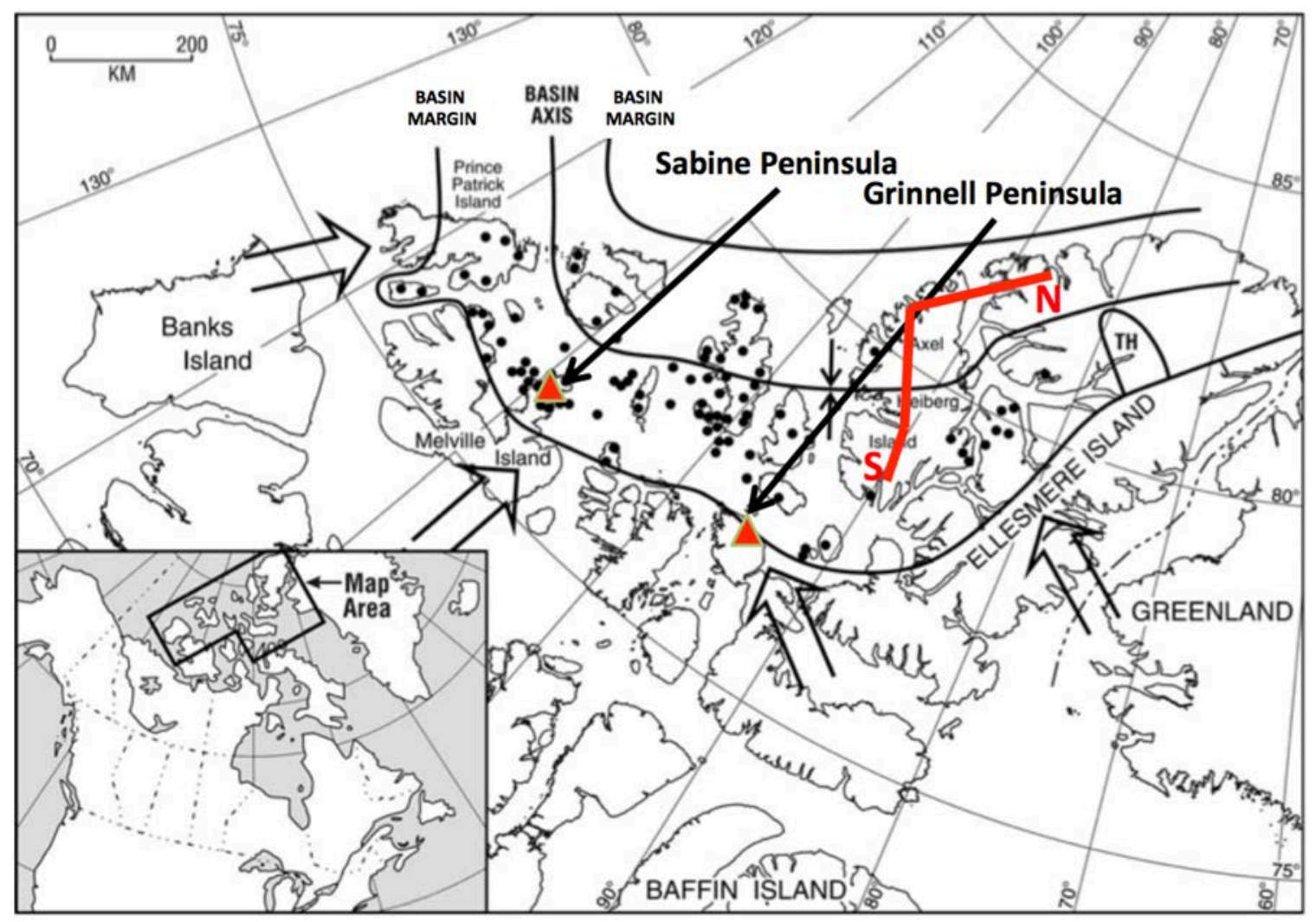

Figure 4.2: Detailed outline map of the Sverdrup Basin axis and margins in Canada's Arctic Islands Showing the locations of the Sabine and Grinnell Peninsulas discussed in the text. $\mathrm{TH}=$ Tanquary High and the black dots denote exploratory well location, some of which encountered HALIP. N-S line (red) represents transect of Sverdrup Basin as shown in Figure 4.1 (from Embry and Osadetz (1988). Map slightly modified from (Embry and Beauchamp, 2008).

As described previously, Cycle 3 of Embry and Osadetz (1988) is manifested in the Strand Fiord Formation flood basalt lavas. Six age results using the ${ }^{40} \mathrm{Ar} /{ }^{39} \mathrm{Ar}$ method from tholeiitic lavas of the Strand Fiord Formation yield ages between 80 and $100 \mathrm{Ma}$ which would imply that magmatism associated with the Strand Fiord Formation lavas was protracted (Villeneuve and Williamson, 2006; Tarduno et al., 1998). However, two reported younger ages of 80 and 83 Ma conflict with the stratigraphic position of the Strand Fiord Formation lava within the Sverdrup Basin (Villeneuve and Williamson, 2006; Embry and Osadetz, 1988) so these younger ages may be unreliable. In northern 
Greenland, ${ }^{40} \mathrm{Ar} /{ }^{39} \mathrm{Ar}$ dating of alkaline dykes yield ca. 80 - 85 Ma ages (Kontak et al., 2001).

\begin{tabular}{|c|c|c|c|c|c|}
\hline Region & Sub-region & Structure & Method & Age +2-sigma & Reference \\
\hline Canada & Axel Heiberg Is & Lava Flow & Ar-Ar & $80.7 \pm 1.1 \mathrm{Ma}$ & Villeneuve \& Williamson (2006) \\
\hline Canada & Axel Heiberg Is & Lava Flow & Ar-Ar & $83.8 \pm 1.2 \mathrm{Ma}$ & Villeneuve \& Williamson (2006) \\
\hline Canada & Axel Heiberg Is & Lava Flow & $\mathrm{Ar}-\mathrm{Ar}$ & $92.3 \pm 1.1 \mathrm{Ma}$ & Villeneuve \& Williamson (2006) \\
\hline Canada & Axel Heiberg Is & Lava Flow & Ar-Ar & $95.3 \pm 0.2 \mathrm{Ma}$ & Tarduno et al. (1998) \\
\hline Canada & Axel Heiberg Is & Lava Flow & $\mathrm{Ar}-\mathrm{Ar}$ & $96.1 \pm 1.9 \mathrm{Ma}$ & Villeneuve \& Williamson (2006) \\
\hline Canada & Devon Is & Dyke & K-Ar & $115 \pm 5 \mathrm{Ma}$ & Stevens et al. (1982) \\
\hline Canada & Devon Is & Dyke & K-Ar & $117 \pm 5 \mathrm{Ma}$ & Stevens et al. (1982) \\
\hline Canada & Melville Is & Dyke & K-Ar & $123 \pm 6 \mathrm{Ma}$ & Balkwill \& Haimila (1978) \\
\hline Canada & Melville Is & Sill & $\mathrm{K}-\mathrm{Ar}$ & $133 \pm 6 \mathrm{Ma}$ & Balkwill \& Haimila (1978) \\
\hline Canada & Melville Is & Sill & K-Ar & $152 \pm 6 \mathrm{Ma}$ & Balkwill \& Haimila (1978) \\
\hline Canada & Axel Heiberg Is & Dyke & Ar-Ar & $128.2 \pm 2.1 \mathrm{Ma}$ & Villeneuve \& Williamson (2006) \\
\hline Norway & Svalbard & & K-Ar & (78 - 125 [115 Ma]) & Nejbert et al. (2011) \\
\hline Norway & Svalbard & Sill & Ar-Ar & $120.22 \pm 1.87 \mathrm{Ma}$ & Polteau et al. (2016) \\
\hline Russia & Franz Josef Land & Dyke & $\mathrm{Ar}-\mathrm{Ar}$ & $125.2 \pm 5.5 \mathrm{Ma}$ & Koryakin \& Shipilov (2009) \\
\hline Russia & Franz Josef Land & Lava & Ar-Ar & $156 \pm 7.5 \mathrm{Ma}$ & Koryakin \& Shipilov (2009) \\
\hline Russia & Franz Josef Land & Sill & Ar-Ar & $189.1 \pm 11.4 \mathrm{Ma}$ & Koryakin \& Shipilov (2009) \\
\hline Russia & Franz Josef Land & & Ar-Ar & Barremian - Albian & Grogan et al. (2000) \\
\hline
\end{tabular}

Notes: Age determinations ordered by their age and grouped according to their broad age similarites tied to magmatic pulse(s).

Relative to the number of early $\mathrm{K}-\mathrm{Ar}$ and ${ }^{40} \mathrm{Ar} /{ }^{39} \mathrm{Ar}$ age determinations, the number of highly precise U-Pb ages from the High Arctic LIP is small but expanding, enabling refinement on magmatic and volcanic episodes linked to the High Arctic LIP (Table 4.2; Fig. 4.3). U-Pb ages yield robust magmatic ages between 121-126 Ma on Svalbard (Norway), Franz Josef Land (Russia) and Ellef Ringnes Island and 92 Ma on the Wootton Igneous Complex in northern Ellesmere Island (Evenchick et al., 2014; Evenchick et al., 2015; Estrada and Henjes-Kunst, 2013; Corfu et al., 2013; Trettin and 
Parrish, 1987; Thórarinsson et al., 2015). On the Eurasian side of the Arctic (Svalbard, Norway and Franz Josef Land, Russia) six U-Pb ages from four diabasic sills (two each from Svalbard and Franz Josef Land) along with a bentonite ash layer yield a tight age range from $122-126 \mathrm{Ma}$ (Corfu et al., 2013). Note that this is a much tighter age range than reported in Svalbard and Kong Karls Land by Nejbert and others (2011) along with Grogan and others (2000) using the K-Ar and ${ }^{40} \mathrm{Ar} /{ }^{39} \mathrm{Ar}$ methods. In Canada, three U-Pb ages from two diabasic sills and a single pyroclastic unit on Ellef Ringnes Island are 120 and $126 \mathrm{Ma}$ (sills) and $105 \mathrm{Ma}$ (pyroclastic unit; Evenchick et al., 2014; Evenchick et al., 2015). The pyroclastic unit dated may not be part of the HALIP but instead may have been derived from unrelated distant volcanism. 


\begin{tabular}{|c|c|c|c|c|c|}
\hline Region & Sub-region & $\begin{array}{l}\text { Structure / } \\
\text { Swarm }\end{array}$ & Material [1] & Age +2-sigma & Reference \\
\hline Greenland & & N-S dykes & dolerite & $80.8 \pm 0.6 \mathrm{Ma}$ & Thórarinsson et al. (2015) \\
\hline Greenland & & E-W dykes & dolerite & $82.1 \pm 1.5 \mathrm{Ma}$ & Thórarinsson et al. (2015) \\
\hline Canada & Ellesmere Is & Wootton I.C. & & $92.0 \pm 1 \mathrm{Ma}$ & Trettin \& Parrish (1987) \\
\hline Canada & Ellesmere Is & Wootton I.C. & $\mathrm{Gbo}+\mathrm{Gr}+\mathrm{QzSy}$ & $92.1 \pm 0.1 \mathrm{Ma}$ & Estrada \& Henjes-Kunst (2013) \\
\hline Canada & Ellesmere Is & Wootton I.C. & Microgranite & $92.7 \pm 0.3 \mathrm{Ma}$ & Estrada \& Henjes-Kunst (2013) \\
\hline Canada & $\begin{array}{l}\text { Ellef } \\
\text { Ringnes Is }\end{array}$ & Tuff layer & Hyalotuff & $105.4 \pm 0.22 \mathrm{Ma}$ & Evenchick et al. (2015) \\
\hline Canada & $\begin{array}{l}\text { Ellef } \\
\text { Ringnes Is } \\
\text { Franz Josef }\end{array}$ & Sill & gabbro & $120.8 \pm 0.8 \mathrm{Ma}$ & Evenchick et al. (2015) \\
\hline Russia & $\begin{array}{l}\text { Land } \\
\text { Franz Josef }\end{array}$ & Sill & mafic & $122.2 \pm 1.1 \mathrm{Ma}$ & Corfu et al. (2013) \\
\hline Russia & Land & Sill & mafic & $122.7 \pm 0.3 \mathrm{Ma}$ & Corfu et al. (2013) \\
\hline Norway & Svalbard & Tuff layer & Bentonite & $123.3 \pm 0.2 \mathrm{Ma}$ & Corfu et al. (2013) \\
\hline Norway & Svalbard & Sill & mafic & $124.5 \pm 0.2 \mathrm{Ma}$ & Corfu et al. (2013) \\
\hline Norway & $\begin{array}{l}\text { Svalbard } \\
\text { Ellef }\end{array}$ & Sill & mafic & $124.7 \pm 0.3 \mathrm{Ma}$ & Corfu et al. (2013) \\
\hline Canada & Ringnes Is & Sill & diabase & $126.6 \pm 1.2 \mathrm{Ma}$ & Evenchick et al. (2015) \\
\hline
\end{tabular}

Notes: Age determinations grouped according to their broad age similarities and thereby magmatic pulse(s)

[1] The terminology used is as reported in the

respective reference

I.C. = Igneous Complex

Figure 4.3 (next page): U-Pb age spectrum "barcode" of dated mafic intrusions ascribed to the HALIP. Thin horizontal lines represent individual reported ages with grey vertical rectangles representing $2 \sigma$ uncertainties. Lower-case " $b$ " represents age determinations from baddeleyite, lower-case " $t$ " represent age of titanite, determinations without lowercase letters are from zircon. Orange rectangles in the Canada/Greenland column represent the four volcanic cycles of Embry and Osadetz (1988). Key to abbreviations: PIM, IF = Paterson Island Member of Isachsen Formation; WIM, IF = Walker Island Member of Isachsen Formation; SFF = Strand Fiord Formation; HPV = Hansen Point Volcanics; W.I.C. = Wootton Igneous Complex; EI= Ellesmere Island; AHI = Axel Heiberg Island, EHI = Ellef Ringnes Island; Svbd = Svalbard (Norway); FJL = Franz Josef Land (Russia). Key to data sources: A and B this study; 1 = Thórarinsson et al. (2015); 2 = Trettin and Parrish (1987); 3 = Estrada and Henjes-Kunst (2013); 4 = Evenchick et al. (2015); 5 = Corfu et al. (2013). 


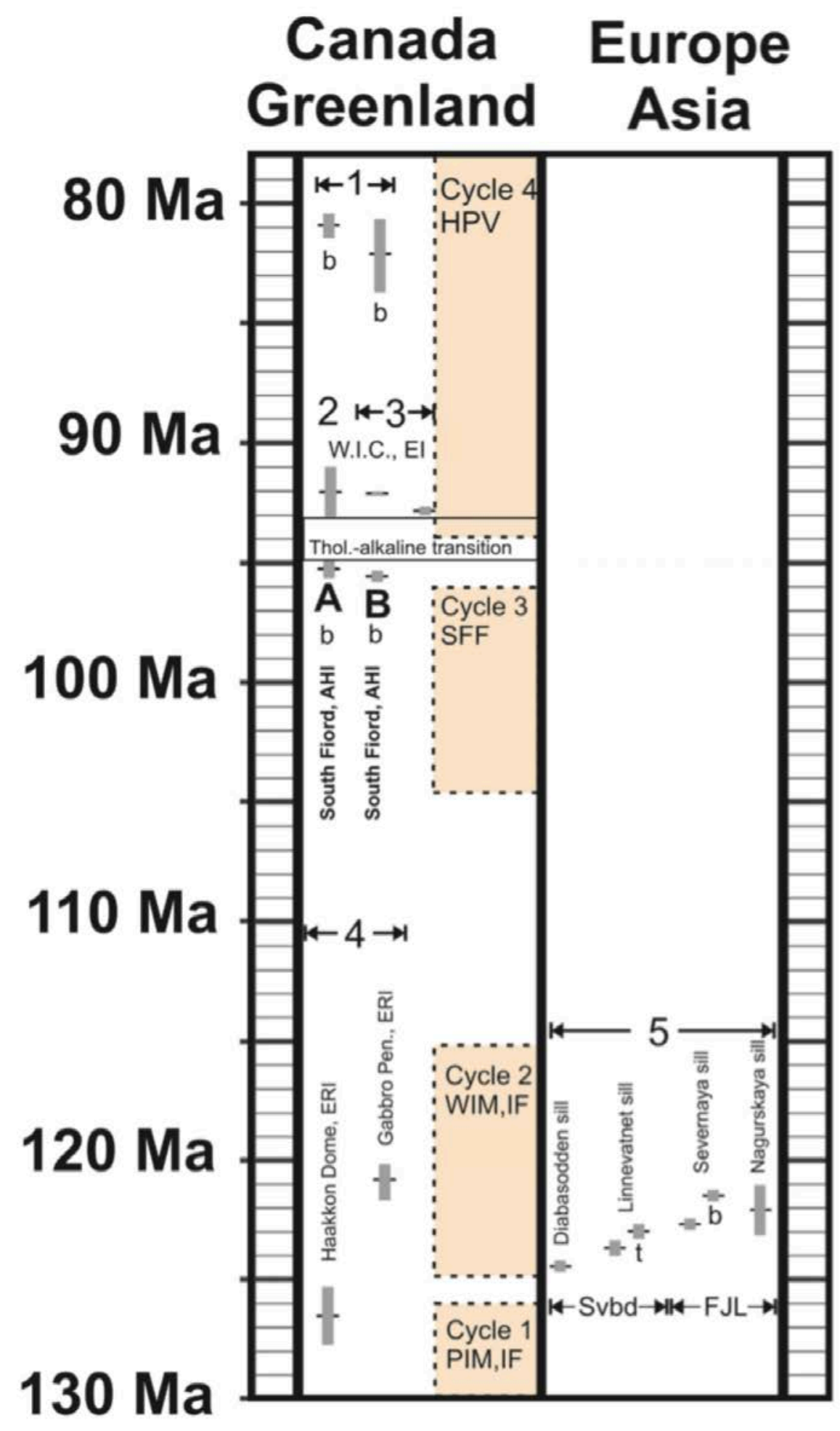


The 120-125 Ma pulse of magmatism is scattered about the Arctic Margins (e.g. Evenchick et al., 2015; Corfu et al., 2013) which in Canada corresponds with volcanic Cycles 1 and 2 (Embry and Osadetz, 1988). A younger pulse ensued approximately 30 Ma later, affecting the Canadian side of the Arctic Ocean. Two separate studies on the gabbroic - microgranite Wootton Igneous Complex yielded U-Pb ages of $92.0 \pm 1.0 \mathrm{Ma}$ (Trettin and Parrish, 1987) and 92.1 $\pm 0.1 \mathrm{Ma}$ (Estrada and Henjes-Kunst, 2013) on the gabbroic component along with $92.7 \pm 0.3 \mathrm{Ma}$ for three micro-granite analyses (Estrada and Henjes-Kunst, 2013). The Wootton Igneous Complex at first glance, represents a plausible intrusive component connected with the plumbing system which fed the Strand Fiord Formation volcanism (Cycle 3), and thus far, the only intrusion that has produced precise $\mathrm{U}-\mathrm{Pb}$ ages in the $90-100 \mathrm{Ma}$ range associated with the High Arctic LIP in Canada. However, based on geochemical studies coupled with the U-Pb dates presented above, the Wootton Igneous Complex is predominantly alkaline and so would represent initiation of the alkaline period of magmatism (Estrada and Henjes-Kunst, 2013) and by extension not be associated with tholeiitic South Fiord intrusive and the Strand Fiord volcanism (Chapter 3). Finally, two U-Pb determinations of alkaline dykes on Greenland give ages of 81 and $82 \mathrm{Ma}$, and their emplacement is linked to initial events that led to rifting of the Gakkel Ridge, and are thus distinct from older LIP-related subalkaline magmatism (Thórarinsson et al., 2015).

In the following, we report the first precise $\mathrm{U}-\mathrm{Pb}$ baddeleyite ages from mafic intrusions in the South Fiord region of Axel Heiberg Island, and these age are consistent with the timing of the Late Cretaceous Strand Fiord Formation. These new ages are then used to (a) refine our understanding of the magmatic evolution of the third volcanic cycle 
of HALIP (Fig. 4.1; Embry and Osadetz, 1988) by focusing on how the Strand Fiord Formation lavas evolved through time in terms of duration, and (2) make broader scale inferences about the geometry of the Strand Fiord Formation plumbing system based on mapping in the South Fiord region (Chapter 2).

\subsection{METHODS}

\subsubsection{Field work}

As noted in Chapter 2, field work was conducted in the summer of 2013 in the vicinity of South Fiord, located on the central portion of Axel Heiberg Island's west coast (yellow box in Fig. 4.4; Kingsbury et al., 2014). The purpose of this field campaign was to collect samples of mafic rocks from tabular intrusions comprising the South Fiord intrusive suite along with a lava flow exposed within the dominantly siliciclastic Isachsen Formation (labeled Ki in Fig. 4.5) in order to understand the chemical evolution of these rocks (Chapter 3 ) in addition to obtaining high-precision $\mathrm{U}-\mathrm{Pb}$ age determinations. This field area is characterized by high-relief topography owing to tectonism associated with the Paleocene - Eocene Eurekan orogeny, a period of mountain building, as well as present-day deformation due to upwelling evaporite diapirs such as the South Fiord Diapir and East Fiord Diapir - South (Jackson and Harrison, 2006; Embry and Beauchamp, 2008). For geochronology, two samples were collected and the sample locations for this study are shown in Figure 4.5. The sample locations contained outcrops of coarse-grained mafic rocks that are needed (as discussed in the next section) to permit extraction of baddeleyite. 


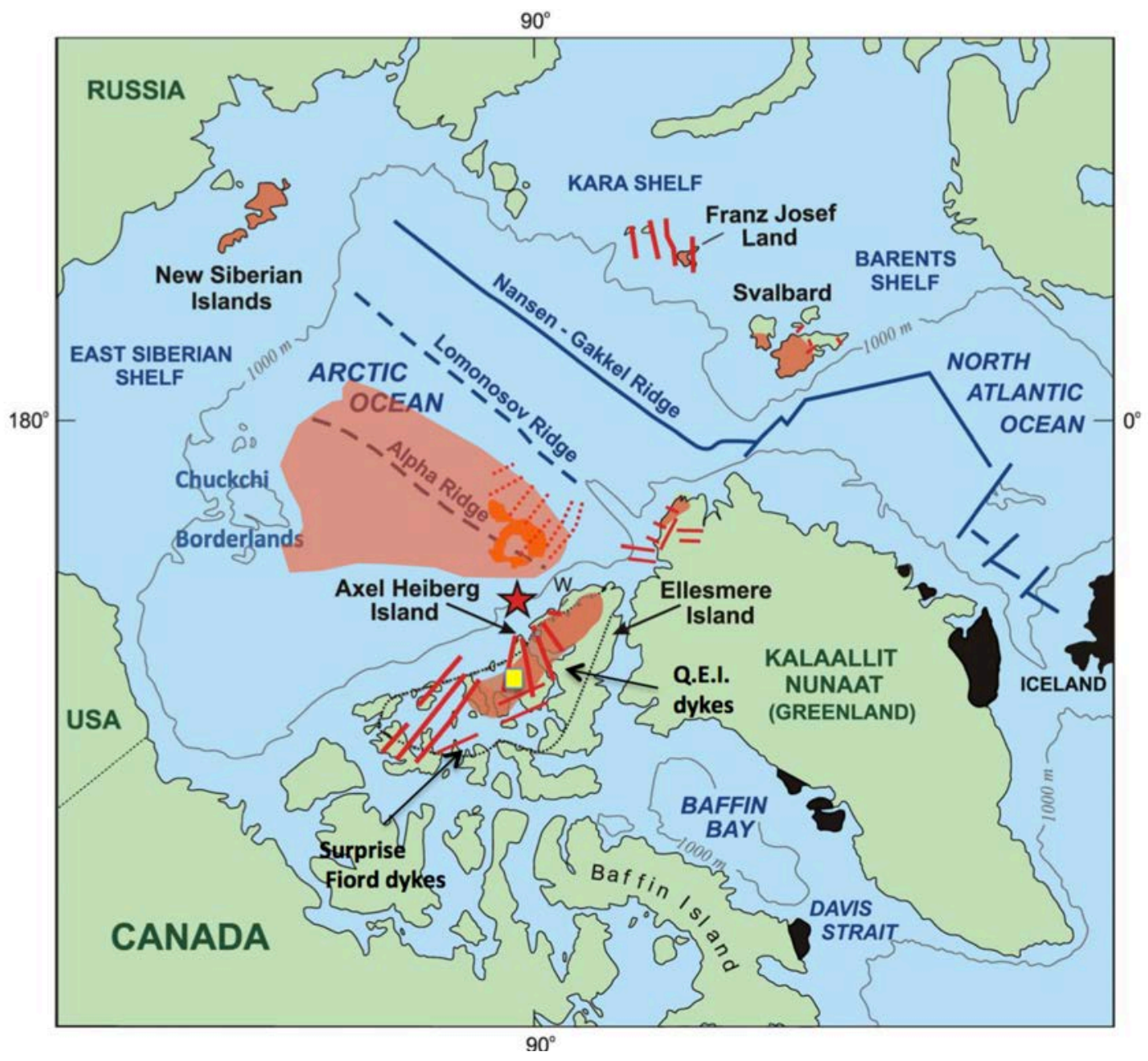

Figure 4.4: Generalized map showing circumpolar distribution of the HALIP. Yellow Box on Axel Heiberg Island represents the location of the South Fiord study area discussed in this text. Orange shading in Alpha Ridge approximates distribution of the portion of the HALIP associated with a deep-crustal root based on aeromagnetic modeling (Saltus et al., 2011; Oakey and Saltus, 2016). Red lines denote orientation of dyke swarms ascribed to HALIP (Buchan and Ernst, 2006) that in Canada have been classified into the Queen Elizabeth Island (Q.E.I.) dyke swarm originally identified in Embry and Osadetz, (1988). Red star denotes the probable location of mantle plume impingement based on the converging radiating dykes. Small grey rectangle just south of "W" marks the location of the Wootton Igneous Complex dated by Trettin and Parrish (1987) as well as Estrada and Henjes-Kunst, (2013). Black stippled line outlines the Sverdrup Basin from Embry and Osadetz, (1988). Black shading in on Greenland's central coasts represents the unrelated North Atlantic Igneous Province. Map modified from Jowitt et al. (2014). 


\subsubsection{Sample selection and processing}

Samples showing potential evidence for analyzable baddeleyite crystals such as coarse grained texture (diabasic - gabbroic) along with elevated $\mathrm{Zr}$ concentrations (greater than $\sim 200 \mathrm{ppm}$ ) as determined from bulk composition analyses, were slabbed and made into single-polished thin sections. Thin sections were then visually searched using the electron microprobe at Carleton University in order to determine whether samples contained baddeleyite of sufficient size ( $>\sim 20$ microns) and abundance to permit successful separation. From these samples, two samples with confirmed baddeleyite of sufficient size ( $>20 \mu \mathrm{m})$ and abundance were selected for further processing and analysis. From each of these two samples (see Section 3.2), slabs were cut weighing $~ 1$ $\mathrm{kg}$ were placed into separate and sealed labeled bags and shipped for baddeleyite processing at the Lund University (Sweden) in the laboratory of Prof. U. Söderlund. At Lund University, baddeleyites were separated using the method developed by Söderlund and Johansson (2002). This method loads milled sample onto a shaking table, using water to preferentially separate higher density minerals from lower density fractions and then uses a magnet to remove any remaining magnetite. Then baddeleyite grains were hand picked from the heavy mineral separate under a binocular microscope. Grains from each sample were then secured in separate, sealed and labeled dishes and then sent to the Jack Satterly Geochronology Lab at the University of Toronto, Canada for dating by Dr. S. Kamo using the isotope dilution-thermal ionization mass spectrometer (ID-TIMS) method. 


\subsubsection{Mass spectrometry}

$\mathrm{U}-\mathrm{Pb}$ analysis was by isotope dilution thermal ionization mass spectrometry methods (ID-TIMS) at the Jack Satterly Geochronology Laboratory at the University of Toronto. Prior to analysis, the baddeleyite crystal separates were cleaned in $8 \mathrm{~N} \mathrm{HNO}_{3}$ at room temperature. For dissolution, the separates were placed in Teflon capsules with a known quantity of a mixed ${ }^{205} \mathrm{~Pb}-{ }^{233-235} \mathrm{U}$ spike (from the EARTHTIME Project; http://www .earth-time.org/u-pb.html) and $\sim 0.10 \mathrm{ml}$ of concentrated HF acid and $\sim 0.02 \mathrm{ml}$ of $7 \mathrm{~N} \mathrm{HNO}_{3}$ at $195^{\circ} \mathrm{C}$ for $\sim 3$ days (Krogh, 1973). Samples were dried to a precipitate and re-dissolved in $\sim 0.15 \mathrm{ml}$ of $3 \mathrm{~N} \mathrm{HCl}$ overnight. $\mathrm{U}$ and $\mathrm{Pb}$ were isolated from the zircon solution using anion exchange columns and $\mathrm{HCl}$ (Krogh, 1973), deposited onto outgassed rhenium filaments with silica gel (Gerstenberger and Haase, 1997), and analyzed in a VG354 mass spectrometer using a Daly detector in pulse counting mode. Corrections to the ${ }^{206} \mathrm{~Pb}^{238} \mathrm{U}$ ages for initial ${ }^{230} \mathrm{Th}$ disequilibrium in the zircon have been made assuming a $\mathrm{Th} / \mathrm{U}$ ratio in the magma of 4.2. All common $\mathrm{Pb}$ was assigned to procedural Pb blank. Dead time of the measuring system for Pb and $\mathrm{U}$ was 16 and $14 \mathrm{~ns}$, respectively. The mass discrimination correction for the Daly detector is constant at $0.05 \%$ per atomic mass unit. Amplifier gains and Daly characteristics were monitored using the SRM $982 \mathrm{~Pb}$ standard. Thermal mass discrimination corrections are $0.10 \%$ per atomic mass unit for both $\mathrm{Pb}$ and U. Decay constants are those of Jaffey et al. (1971). All age errors quoted in the text and table, and error ellipses in the Concordia diagrams are given at the $95 \%$ confidence interval. VG Sector software was used for data acquisition. In-house data reduction software in Visual Basic by D.W. Davis was used. Plotting and age calculations were done using Isoplot 3.00 (Ludwig, 2003). 


\subsection{RESULTS}

\subsubsection{Sample and collection site descriptions}

\subsubsection{1: Sample 13-CK-16 (Lat 79.3766 N, Long 93.6315 W)}

This sample of diabase was collected from along a NW-SE trending ridge from a small ( $\sim 5 \mathrm{~m} \mathrm{x} \sim 5 \mathrm{~m})$ subcrop of metre-sized diabasic rocks within a talus slope. Because ridge and mountain slopes surrounding the collection site are mantled with significant talus (as well as the field area more broadly) it is difficult to be certain whether the sampled body is a dyke or a sill. However, this diabase likely is from a dyke (Fig. 4.5) on the basis of $\sim 45^{\circ} \mathrm{NE}$ dipping tops of columnar cooling joints on a ridge $\sim 700 \mathrm{~m}$ along strike SSE of the sample location whereas sedimentary rocks on geologic maps dip west (Jackson and Harrison, 2010; Thorsteinsson and Tozer, 1971; see Chapter 2). If so, then this dyke would have a trend between that of the SE-trending Cornwall dyke swarm and the N-S trending Lightfoot River dykes of the radiating Queen Elizabeth swarm (Buchan and Ernst, 2013). Chemically, this sample is classified as a subalkaline basalt following the scheme of Pearce and Norry (1979) and contains 249 ppm $\mathrm{Zr}$ (Chapter 3). A more complete discussion of geochemistry of this sample is provided in Chapter 3.

\subsubsection{2: Sample 13-WJA-C028-A2 (Lat 79.2797 N, Long 94.1806 W)}

This sample is a coarse-grained gabbro and was collected from the upper part of a $>50 \mathrm{~m}$ thick sill that forms a prominent ridge that is exposed on the peninsula south of the 2013 field area (Fig. 4.5; Chapter 2). Buchan and Ernst (2013) originally identified this body as a dyke of the SW-NE trending Surprise Fiord swarm. However, on the basis of field observation during the 2013 field expedition (Kingsbury et al., 2014), it was determined to be a sill. Kingsbury et al. (2014) noted vertically-oriented sets of 
hexagonal cooling joints on the cliff-face. The true thickness of this sill is unknown because the sample site on the top of the ridge contains coarse-grained gabbroic rock thereby implying that the upper portion (medium to fine-grained to chilled) was removed by erosion. Chemically, this sample is a subalkaline basaltic andesite based on the systematics of Pearce and Norry (1979). This is the only sample collected in the South Fiord area which falls outside the subalkaline basalt field in the Pearce and Norry (1979). It is a subalkaline basaltic andesite, which may be explained by in-situ crystal settling of mafic minerals towards the base of the sill thereby enriching this upper part in silica in the form of plagioclase and trace quantities of quartz (Chapter 3). On the basis of its high $\mathrm{Zr}$ content, $405 \mathrm{ppm}$, it represented a good target for U-Pb dating. See more detailed geochemical discussion of this and related samples in Chapter 3.

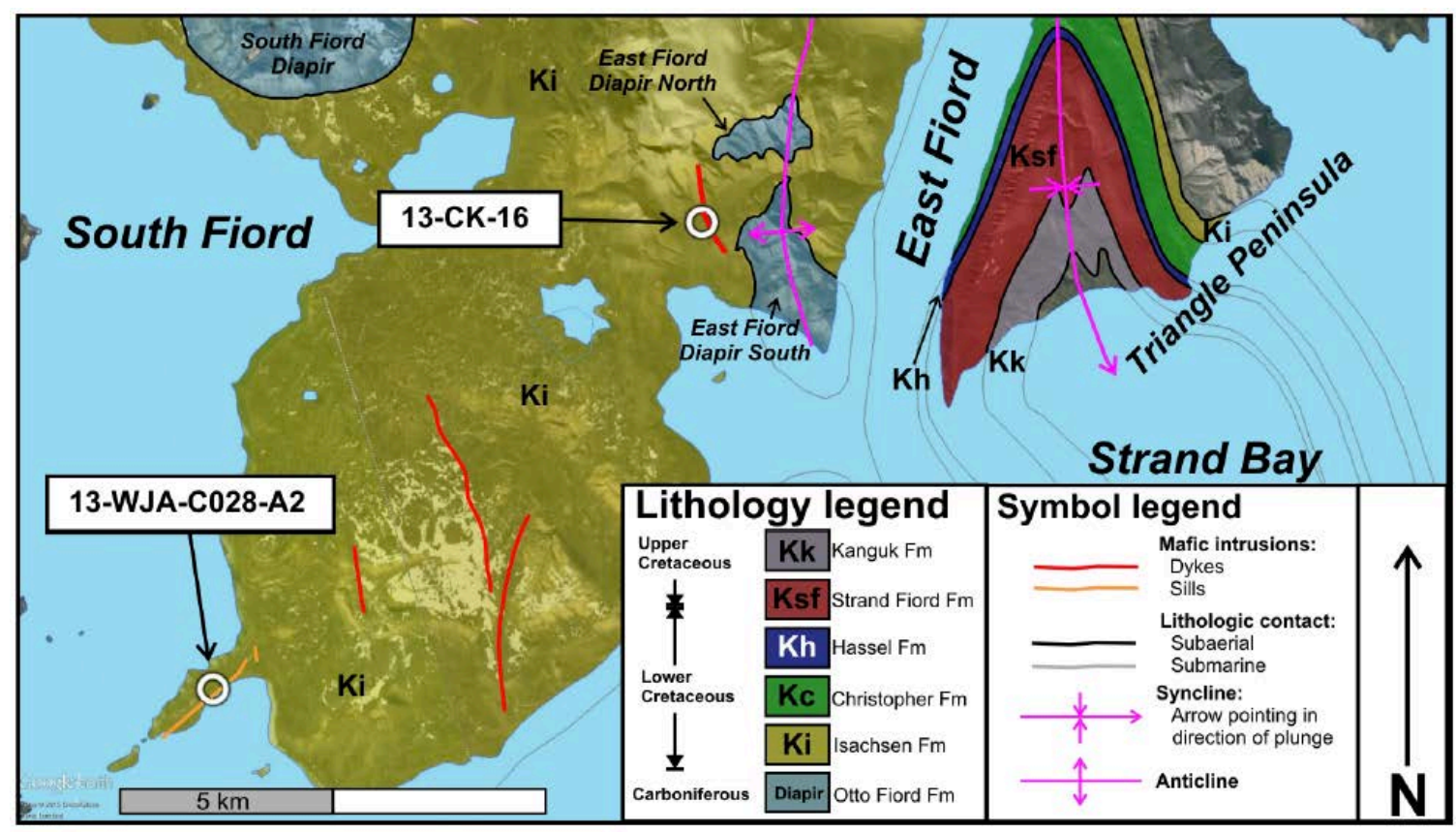

Figure 4.5: Geologic map draped onto Google Earth ${ }^{\circledR}$ showing the general geology of the South Fiord region along with the location of the two samples selected for U-Pb dating. Geology from Jackson and Harrison (2010) and intrusions from Buchan and Ernst (2013) with the exception of the dyke from where sample 13-CK-16 was collected and mapped in Chapter 2. Scale bar is $10 \mathrm{~km}$ separated into two $5 \mathrm{~km}$ segments. 


\subsubsection{Baddeleyite morphology and characteristics}

Baddeleyite grains, both those imaged under the electron microprobe as well as those extracted in both samples, show the characteristic prismatic to blocky morphology that typifies baddeleyite (Figs. 4.6 and 4.7). Because sample 13-WJA-C028-A2 is a coarse-grained gabbro while 13-CK-16 is diabasic, baddeleyites were significantly larger in the gabbro than the diabase sample. The largest baddeleyite grain in the diabase found using the electron microprobe measured approximately $25 \mu \mathrm{m}$ in the longest dimension (Fig. 4.6A) while grains with maximum dimensions of $50 \mu \mathrm{m}$ were ultimately extracted (Fig. 4.6B). In the gabbro, the grain with the longest dimension found using the electron microprobe was $\sim 100 \mu \mathrm{m}$ (Fig. 4.7A) with similar approximate measurements for extracted grains (Fig. 4.7B). Owing to relatively fresh and non-metamorphic nature of the diabase and gabbro, no polycrystalline metamorphic zircon rims were observed, as is often the case in mafic rocks that undergo even low-grade metamorphism (Heaman and LeCheminant, 1993; Söderlund et al., 2013). 


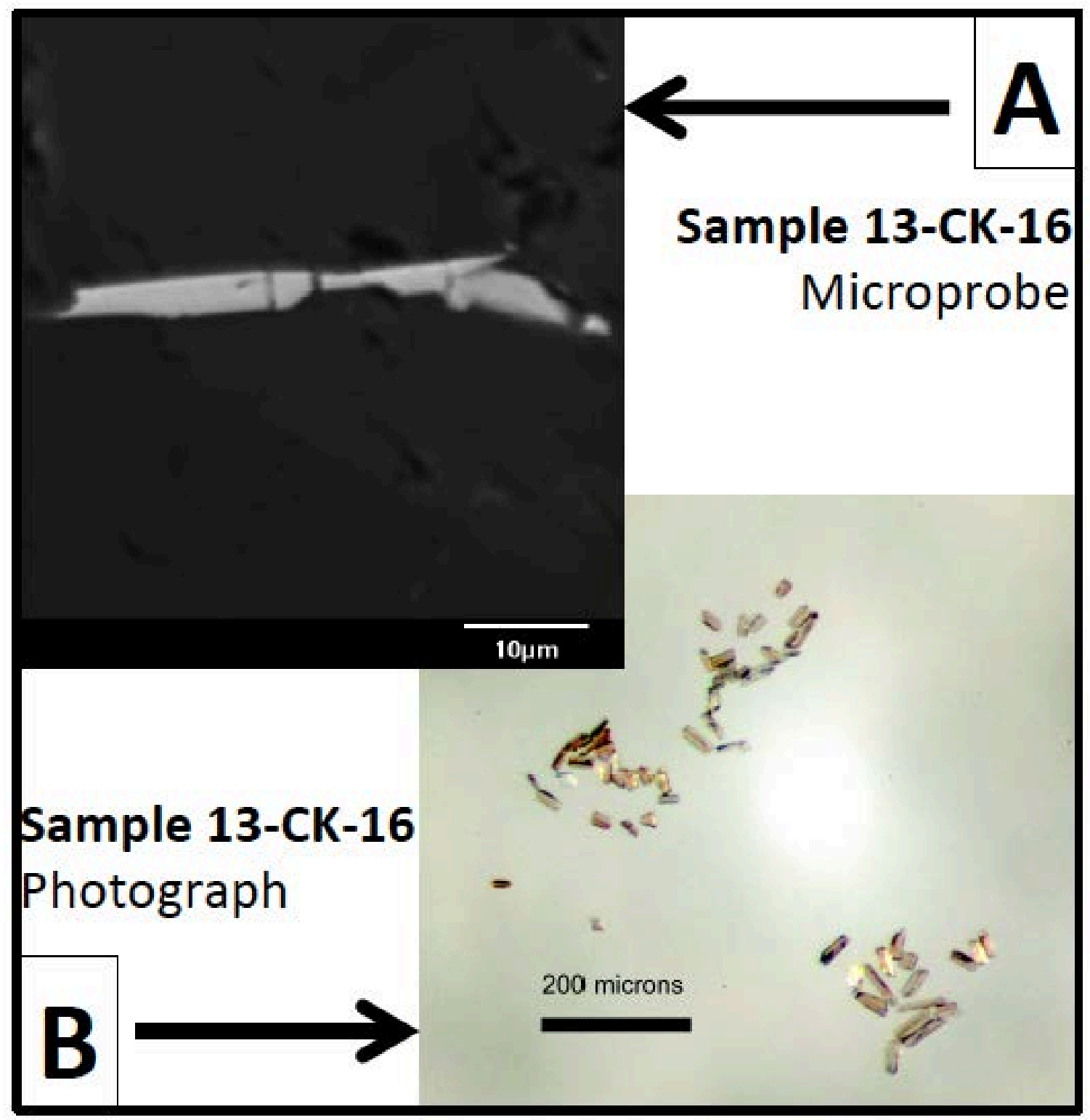

Figure 4.6: A) Scanning Electron Microscope (SEM) - Backscattered Electron imaging (BSE) and (B) photograph of baddeleyite grains from sample 13-CK-16. Note translucent colour and general lath-shaped morphology of the grains. 


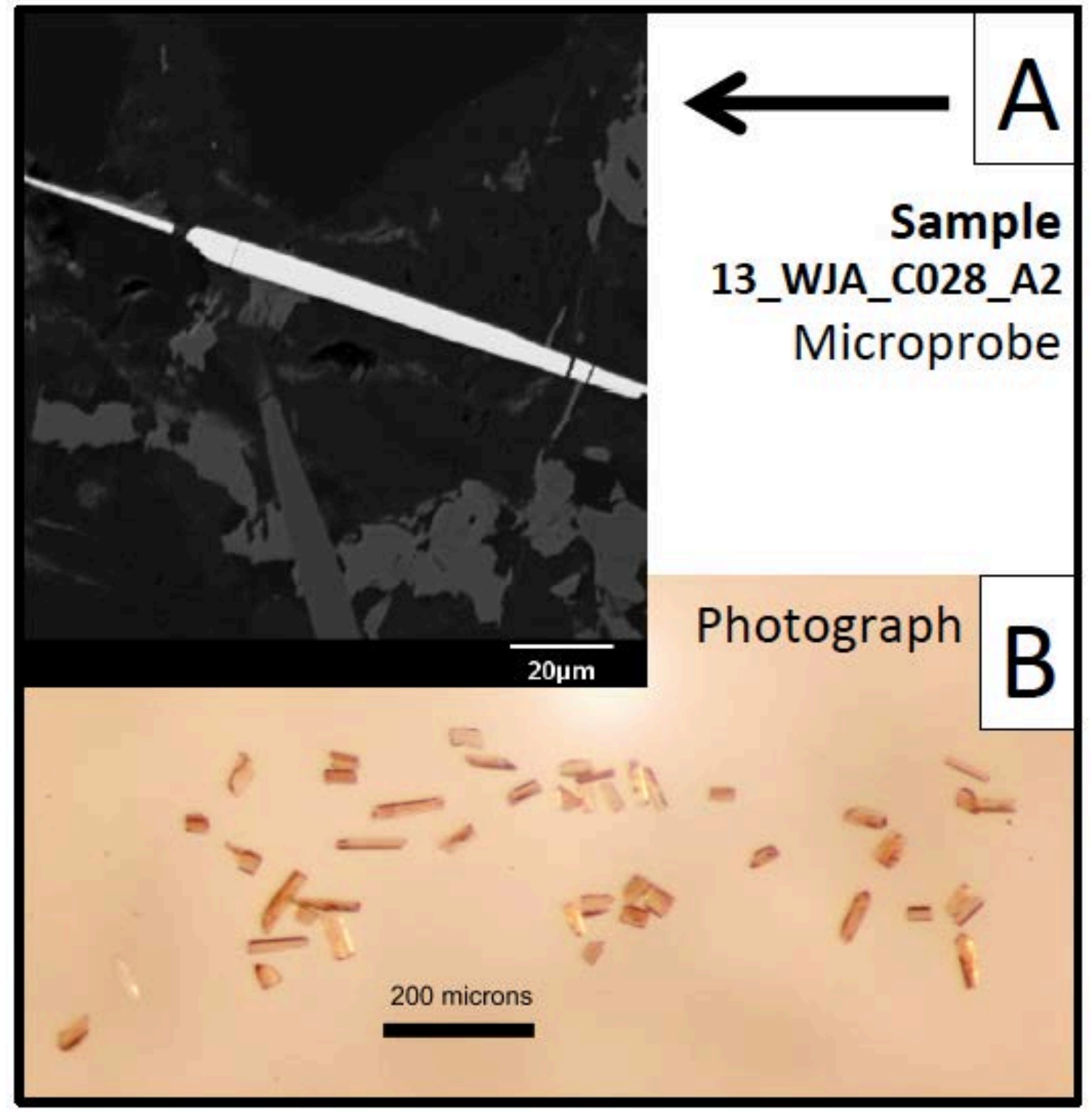

Figure 4.7: (A) SEM-BSE and (B) photograph of baddeleyite grains from sample 13_WJA-C028_A2. Note translucent colour as well as the larger grain size compared with sample 13-CK-16 (Fig. 4.6). 


\subsubsection{U-Pb Geochronology}

\subsubsection{1: Sample 13-CK-16}

For this sample, baddeleyite laths which lacked visible alteration were separated into three fractions that were analyzed via ID-TIMS at the University of Toronto for their $\mathrm{U}$ and $\mathrm{Pb}$ contents and $\mathrm{Pb}$ isotopic compositions. The analytical results (Fig. 4.8;

Appendix 5) produces an overlapping and concordant ${ }^{206} \mathrm{~Pb} /{ }^{238} \mathrm{U}$ weighted mean age of $95.18 \pm 0.35 \mathrm{Ma}(2 \sigma ; \mathrm{MSWD}=0.02)$ that is interpreted to mark the time of emplacement of this dyke.

\subsubsection{2: Sample 13-WJA-CO28-A2}

Alteration-free baddeleyite grains were separated into three multi-grain fractions that were analyzed for their $\mathrm{U}$ and $\mathrm{Pb}$ concentrations and $\mathrm{Pb}$ isotopic compositions via ID-TIMS. Much like sample 13-CK-16, the analyses resulted in concordant data with some overlap; however there is some scatter between the fractions. Nonetheless, the ${ }^{206} \mathrm{~Pb} /{ }^{238} \mathrm{U}$ weighted mean age of the three-fraction data is $95.56 \pm 0.24 \mathrm{Ma}(2 \sigma ; \mathrm{MSWD}=$ 1.9) (Fig. 4.9; Appendix 5).

Both samples discussed above (13-CK-16 and 13-WJA-C028-A2) have baddeleyite determinations that are close enough in age (difference of $0.38 \mathrm{Ma}$ ) that when coupled with their individual analytical uncertainties, their ages cannot be statistically resolved from each other. If we assume that the two samples (which were collected $\sim 16$ $\mathrm{km}$ apart in the field) were derived from the same magmatic event, a weighted composite age determination based on all three fractions of both 13-CK-16 and 13-WJA-C028-A2 is $95.44 \pm 0.20 \mathrm{Ma}(2 \sigma ; \mathrm{MSWD}=1.5 ;$ Fig. 4.10). 


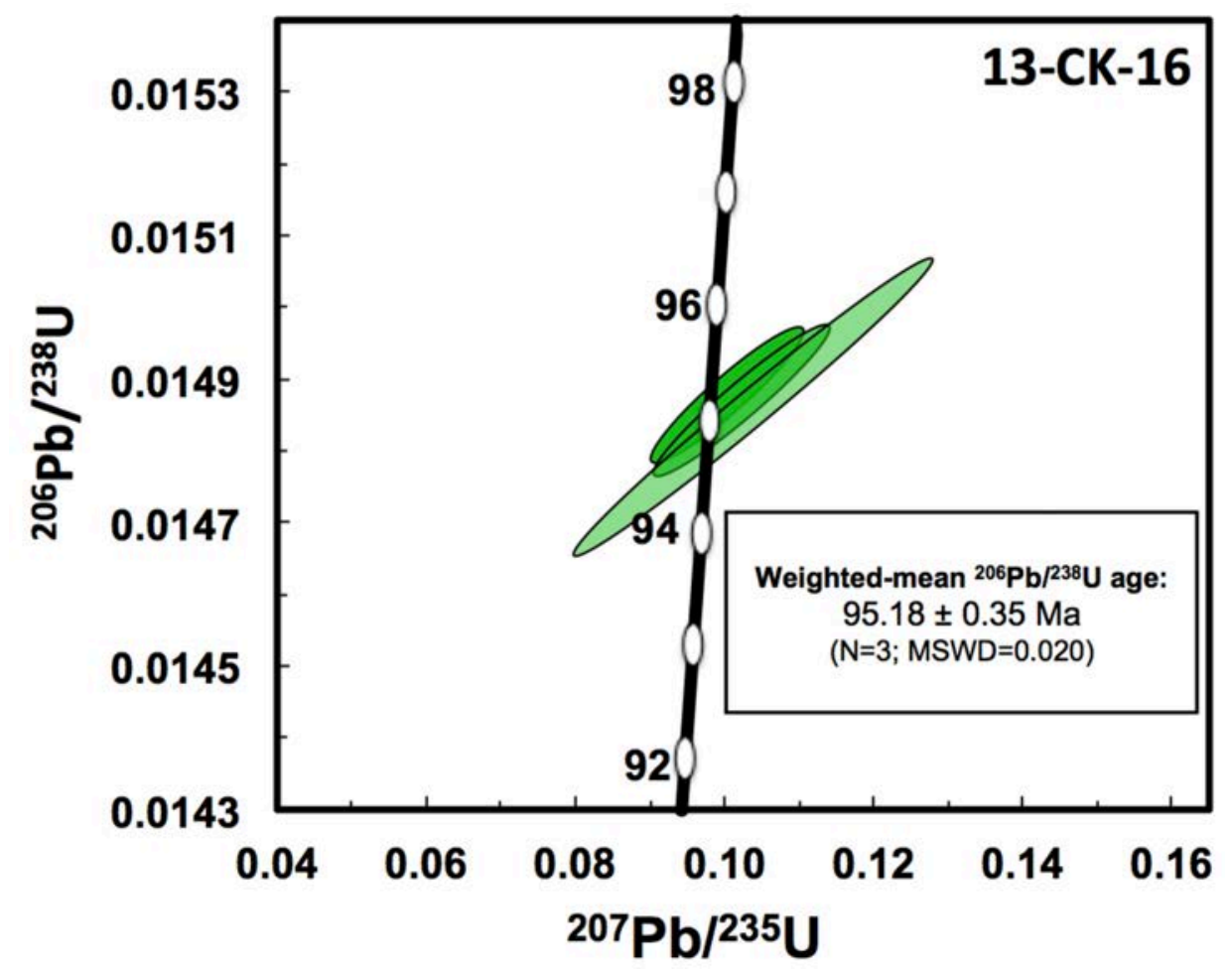

Figure 4.8: U-Pb age concordia diagram from Sample 13-CK-16 (dyke).

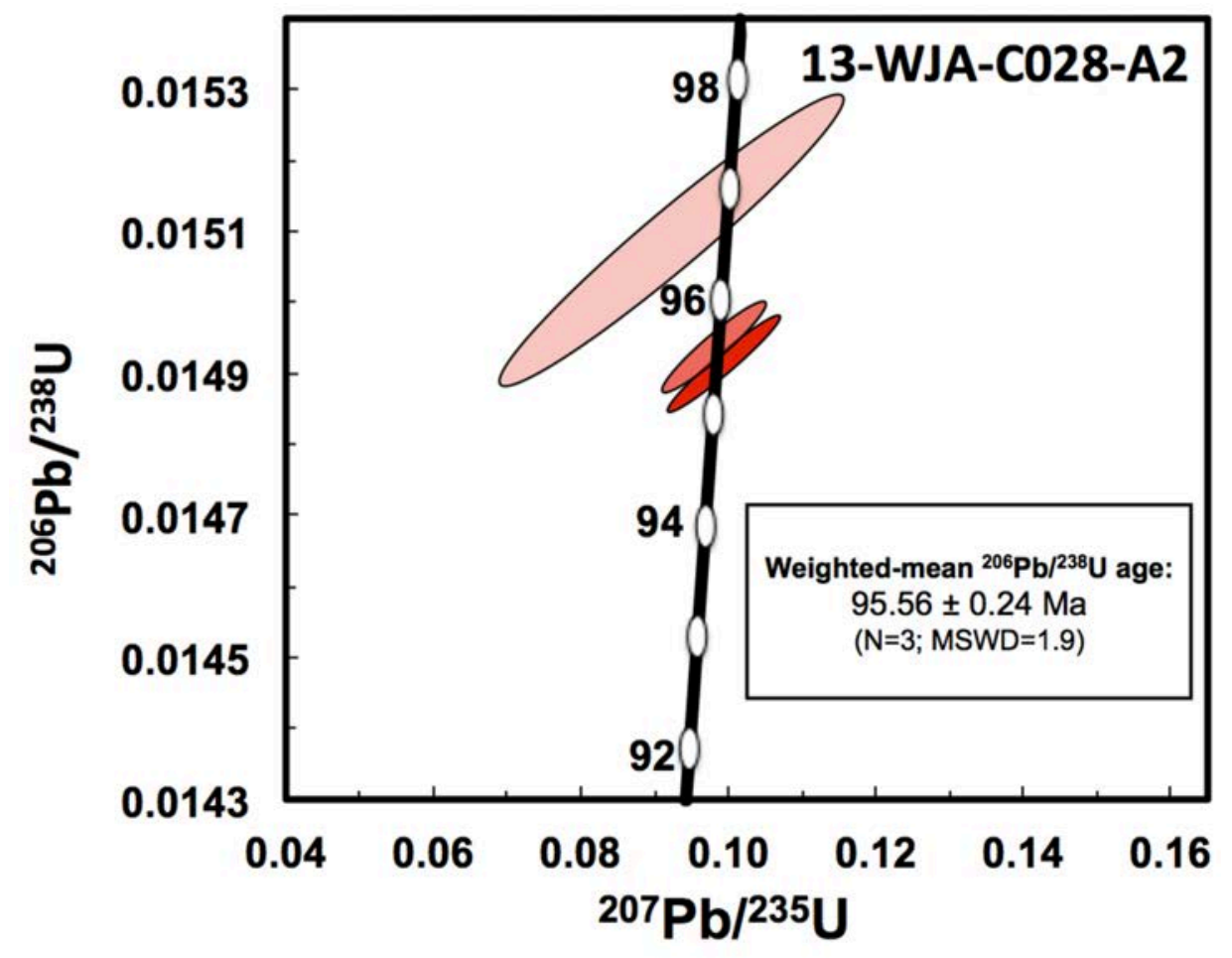

Figure 4.9: U-Pb age concordia diagram from Sample 13-WJA-C028-A2 (sill). 


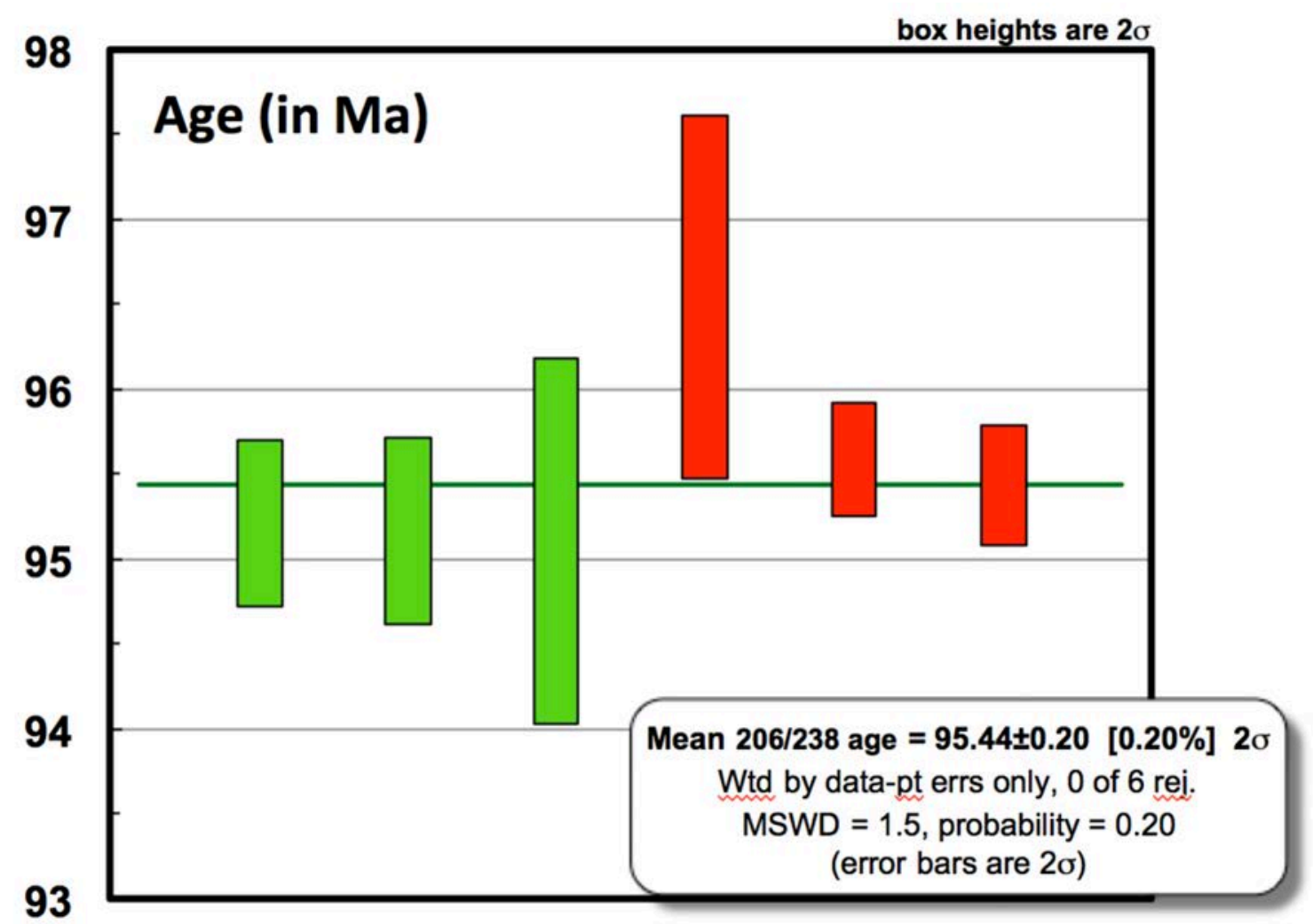

Figure 4.10: Weighted mean U-Pb age of the two samples dated herein. Key to coloured bars: green $=$ Sample 13-CK-16 (dyke); red = sample 13-WJA-C028-A2 (sill). The relative $\mathrm{x}$-axis positions for the three age fractions for each sample are arbitrary.

\subsection{DISCUSSION}

A graphical summary of the new ages and how they fit within the broader family of $\mathrm{U}-\mathrm{Pb}$ ages derived from the HALIP is shown in the age spectrum "barcode" (Fig. 4.3). We now turn towards discussing how these new ages improve our understanding of the magmatic evolution of the HALIP in the South Fiord area (in the 90 - 100 Ma period). 


\subsubsection{Magmatic evolution of the HALIP}

The reported $\mathrm{U}-\mathrm{Pb}$ ages of $95.18 \pm 0.35 \mathrm{Ma}$ and $95.51 \pm 0.24$ for the intrusive units, as described in the previous section, place magmatic activity in the vicinity of South Fiord within the Cenomanian period 94.1 Ma - 100.5 Ma (Cohen et al., 2013; Eldrett et al., 2014; Barker et al., 2011; Ogg et al., 2016) which is consistent with the Cenomanian portion of the Strand Fiord Formation (Cycle 3) as reported in Embry and Osadetz (1988). Furthermore, this period of magmatism occurred c. 3 Ma prior to the emplacement of the alkaline Wootton igneous complex which Estrada and Henjes-Kunst (2013) interpret as marking the start of the bimodal alkaline phase of magmatic and volcanic activity associated with continental rifting. Therefore, the new age determinations represent the time within which plume-head-related magmatism (see Chapter 3) associated with the tholeiitic HALIP waned in connection with regional tectono-magmatic factors that would favour bimodal alkaline magmatic activity such as active rifting in the Arctic margins of Greenland and adjacent parts of Ellesmere Island (Thórarinsson et al., 2011; Thórarinsson et al., 2015; Estrada and Henjes-Kunst, 2013).

\subsubsection{Nature of magmatism in South Fiord}

As stated previously, the slight difference in the two high-precision ages reported above is not statistically significant, but there are slight differences in chemistry between the two dated samples that are outside of analytical uncertainties. In Figure 4.11, Mg\# is plotted against initial ${ }^{143} \mathrm{Nd} /{ }^{144} \mathrm{Nd}$ ratio (modified from Fig. 3.18 in Chapter 3). ${ }^{143} \mathrm{Nd} /{ }^{144} \mathrm{Nd}$ is not affected by pure fractional crystallization, whereas Mg\# decreases with increasing fractional crystallization. In contrast, both ${ }^{143} \mathrm{Nd} /{ }^{144} \mathrm{Nd}$ (and $\varepsilon \mathrm{Nd}$ ) and the $\mathrm{Mg \#}$ would be 
expected to decrease upon contamination from continental crust components (see Chapter 3, Section 3.4.4). In general the South Fiord intrusives trend towards lower Mg\# at less radiogenic $\mathrm{Nd}$ isotope ratios signifying that crustal assimilation is an important process in magmatic evolution, as further evidenced by the commensurate wide range in $\mathrm{Th} / \mathrm{La}$ ratios (Chapter 3). Superimposed on this general assimilation trend of the South Fiord intrusives are three distinct fractional crystallization series based on statistically

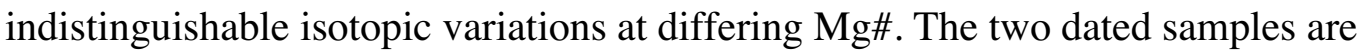
statistically different on the basis of their ${ }^{143} \mathrm{Nd} /{ }^{144} \mathrm{Nd}$ and occupy different positions in two of these three or four horizontal fractional crystallization arrays. Based on the evolutionary patterns just discussed, these fractional crystallization arrays are interpreted as distinct magmatic batches of magma labeled A and B (both of which are dated) and C (that remains undated). Thus, the evolution of magma within the South Fiord field area was largely driven by variable assimilation of sedimentary rocks of the Sverdrup Basin (Chapter 3). These variably contaminated magma batches would then accumulate in a shallow magma chamber and then undergo variable fractional crystallization (to produce the horizontal trends). In the case of sample 13-WJA-C028-A2 the composition may have become more evolved through the process of crystal settling and plagioclase enrichment at the upper part of the sill. Batch $\mathrm{C}$ might actuality be two batches, but equally could be one batch, as small but significant degrees of isotopic heterogeneity are known to exist within single magmatic systems (e.g. small seamounts; Zindler and Hart, 1986). Each of these magmatic batches potentially fed separate flows of the Strand Fiord Formation lavas but could also have been the product of magma emplacement that did not lead to eruption. 


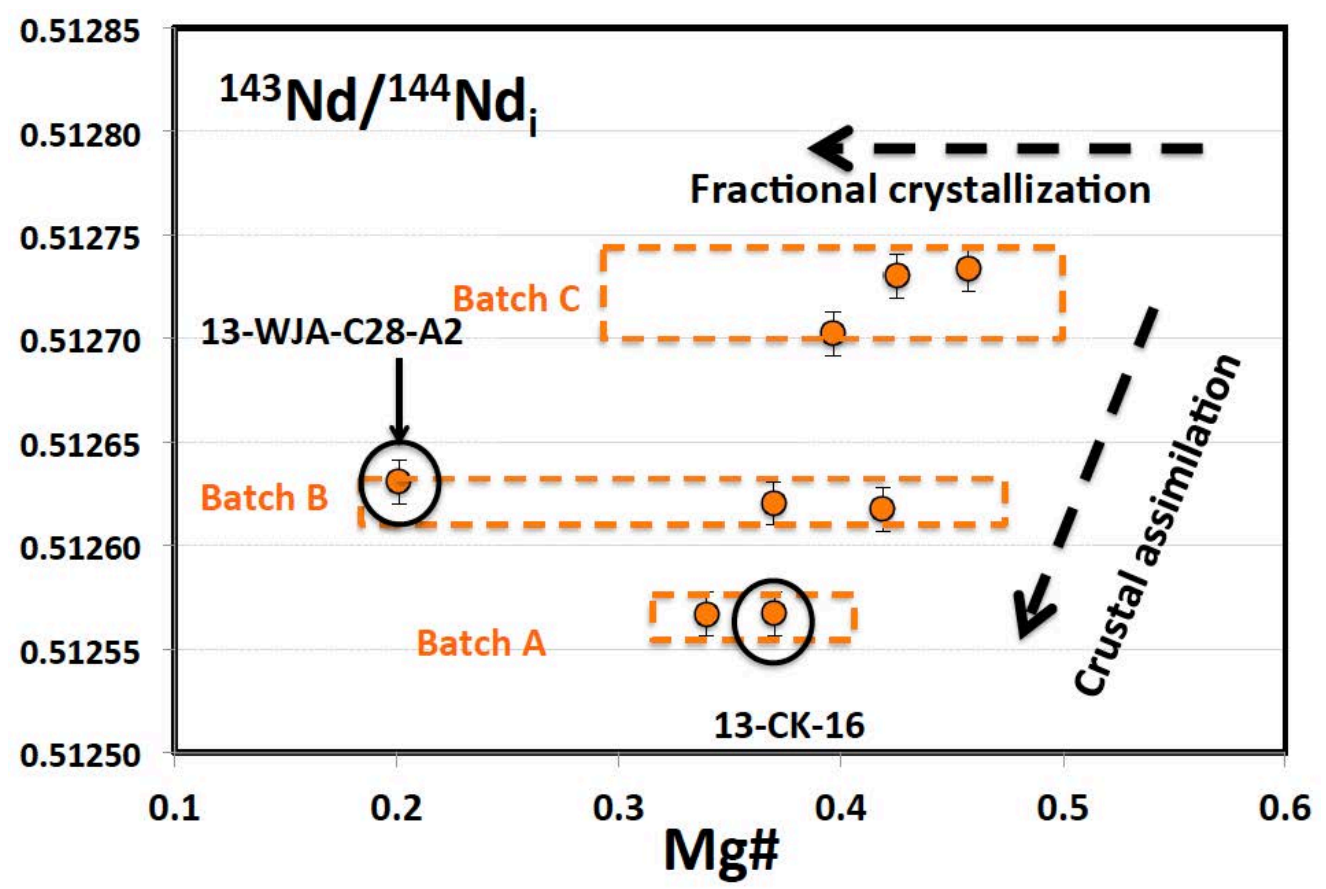

Figure 4.11: $\mathrm{Mg \#}$ vs. ${ }^{143} \mathrm{Nd} /{ }^{144} \mathrm{Nd}_{\mathrm{i}}$ diagram showing chemical signatures of South Fiord intrusives. Black circles and labels highlight the composition in this system of the two dated intrusions discussed herein along with interpreted batches $\mathrm{A}-\mathrm{C}$. Vertical bars denote $2 \sigma$ uncertainties. Chemical data and figure modified from Kingsbury et al. (2016) - Chapter 3. Circled sample in Batch A (13-CK-16) = 95.18 $\pm 0.35 \mathrm{Ma}$; circled sample in Batch B (13-WJA-C028-A2) = 95.56 $\pm 0.24 \mathrm{Ma}$.

\subsubsection{Duration of the Strand Fiord Formation lavas}

The two new ages presented here, allow us to make initial observations about the duration of the Strand Fiord Formation. The chronostratigraphy of the Sverdrup Basin as presented in Embry and Osadetz (1988) implies that intrusions fed older flows of the Strand Fiord Formation lavas during a magmatic pulse that bisected the AlbianCenomanian boundary at 100.5 Ma (Cohen et al., 2013; Ogg et al., 2016). The new ages presented here suggest either that this period of magmatism crossed the Albian-

Cenomanian boundary or that the chronostatigraphic placement of the older flows of the Strand Fiord Formation appearing to span the Albian-Cenomanian boundary as shown by Figure 3 in Embry and Osadetz (1988) may be related to uncertainties in the 
biostratigraphic age. If their stratigraphic placement relative to the geologic time scale of Cohen et al. (2013) as summarized in Ogg et al. (2016) is correct then the duration of the Strand Fiord Formation eruptive sequence is at least $5 \mathrm{Ma}$ and there should be intrusions which fed older Strand Fiord volcanic rocks such as the ca. 100 Ma lavas reported by Villeneuve and Williamson (2006).

Based on stratigraphic measurements of sections around Strand Fiord which contain the highest percentage of volcanic flows with respect with volcaniclastic and epiclastic units (Ricketts et al., 1985; Williamson, 1988), there are two distinct beds of shale which separate basal flows from the more continuous overlying flood basalt package in these sections. In one instance, the shale bed reaches thicknesses of up to 20 $\mathrm{m}$ though more typically is $5-10 \mathrm{~m}$ thick. Thus, it is possible that a small number of Strand Fiord Formation lava flows erupted some time earlier than the bulk of the volcanic sequence and that these basal flows may be Albian in age rather than Cenomanian, consistent with Embry and Osadetz (1988). Consequently, the Strand Fiord Formation lavas may be divided into a "precursory phase" that might extend into the Albian and a "main phase" that is Cenomanian, and therefore the two new U-Pb baddelyite ages date the "main phase" of the Strand Fiord Formation. The idea of a precursory phase of activity occurring before widespread flood volcanism has been noted in the Parana Etendeka LIP, Deccan LIP and the North Atlantic Igneous Province (Jerram and Widdowson, 2005). However, it is unlikely that the Strand Fiord Formation is older than $105 \mathrm{Ma}$ in age, based on a U-Pb age of $105 \mathrm{Ma}$ was obtained from a hyalotuff on Ellef Ringnes Island. The tuff is situated at the boundary between the Invincible Point Member and Macdougall Point Member of the Christopher Formation (Evenchick et al. 2015) - 
stratigraphically below the Hassel Formation which is coeval with the Strand Fiord Formation (Embry and Beauchamp, 2008). It also should be noted that an occurrence of basaltic rocks of transitional subalkaline - alkaline composition erupted within an occurrence of the Hassel Formation located in northern Ellesmere Island (Lake Hazen), with a mean Ar-Ar age of $96 \mathrm{Ma}$, appears to coincide in age with, but is chemically distinct from, the Strand Fiord Formation (Estrada, 2014). In summary, it is further possible that the Strand Fiord Formation lavas began and ceased quickly without any preceding or succeeding episodes which foretell or conclude the main phase of the eruptive period. As alluded to above, the $\sim 20 \mathrm{~m}$ shale deposit identified separating a basal flow with those above it in one stratigraphic column seem to argue against a shorter duration (Williamson, 1988). More U-Pb age analyses from the Strand Fiord Formation feeder system will further refine the timing and duration of the Strand Fiord Formation eruptive sequence.

\subsection{4: Relations to underlying magmatic intrusions}

The intrusions exposed in the local South Fiord region of Axel Heiberg Island are shown to be connected to Strand Fiord Formation volcanism. However, the underlying structure of the Strand Fiord Formation plumbing system on a regional scale is unclear, especially when considering there are other dykes with age determinations commensurate with the older Isachsen Formation lavas (e.g. Villeneuve and Williamson, 2006). Discriminating between dyke sets that fed Strand Fiord Formation lavas rather than the older Isachsen Formation flows is an issue in the study of the Canadian sector of the HALIP. For example, determining the trends of the dyke sets which fed the younger Strand Fiord Formation lavas as opposed to those feeding the older Isachsen Formation 
flows may reveal a transition in tectonic stressors in the intervening c. 30 Ma between the two magmatic pulses, (c.f.. Hou, 2012) or changes in the underlying mantle flow patterns. From the perspective of this study of South Fiord intrusions it is noted in the Results section (Section 4.3) that sample 13-CK-16 was collected from a dyke that trends SSE and that is approximately parallel to a system of dykes that Buchan and Ernst (2013) assign to the Cornwall dyke swarm (Fig. 4.12). Analyzing the dyke distribution on Google Earth ${ }^{\circledR}$ reveals that much of the Cornwall swarm is concentrated along the western margins of Axel Heiberg Island, and that this swarm strikes generally SE. Furthermore, it is important to note that the aforementioned dykes closely overlap in geographic extent and follow the general oblong SSE geographic distribution of the Strand Fiord Formation which generally thins to the SSE (e.g. Section 4.1.1; Fig. 8 in Estrada and Henjes-Kunst, 2004; Fig. 1 in Ricketts et al., 1985) with the significant caveat that its present extent is limited by c. 95 Myr of erosion associated with Eurekan deformation. Furthermore it is highly probable that many dykes are concealed within the ice-fields which occupy central Axel Heiberg Island. This leads to a tentative conclusion that dykes which strike SSE, especially along western Axel Heiberg Island, are likely feeders to the Strand Fiord Formation lavas. In a compilation of Circum-Arctic dyke swarms, Buchan and Ernst (2013) have classified SE trending dykes mainly on western Axel Heiberg Island as being part of the Cornwall dyke swarm and would, according to the analysis herein, likely represent feeders for the Strand Fiord Formation lavas, whereas the radiating Queen Elizabeth Islands dykes are likely feeders for the older Isachsen Formation lavas on the basis of a $128 \mathrm{Ma}$ Ar-Ar age for one such dyke near Lightfoot River (Villeneuve and Williamson, 2006). 


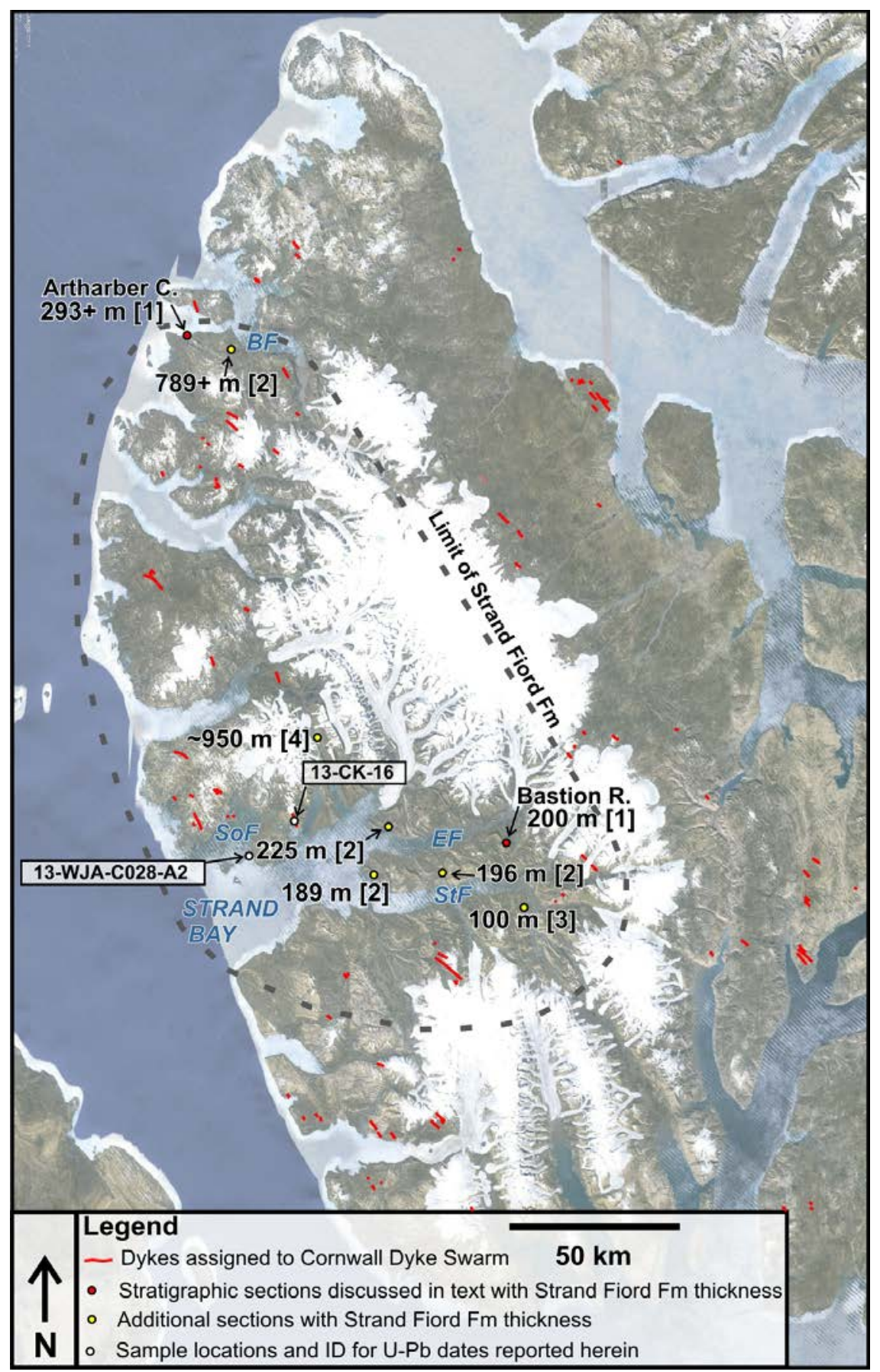

Figure 4.12: Map showing the relations between the geographic distribution of Strand Fiord Formation lavas and the distribution of SE trending dykes (classified as the Cornwall swarm) ascribed to the HALIP (Buchan and Ernst, 2013; Fig. 1A in Estrada and Henjes-Kunst, 2013). The thickness of Strand Fiord Formation lavas from Bastion Ridge and Artharber Creek localities along with select supplementary sections of the Strand Fiord Formation are shown. Key to Strand Fiord Formation thickness data sources: $1=$ Williamson (1988) ; 2= Ricketts et al. (1985); 3 = Embry and Osadetz (1988); 4 = Saumur et al. (2016). 


\subsection{CONCLUSIONS}

Two new U-Pb ages of ca. 95 Ma provide the first high-precision U-Pb ages which date the intrusions on Axel Heiberg Island, and show that they acted as feeders for the Strand Fiord Formation lavas as opposed to lavas of the Isachsen Formation.

Furthermore, these represent the youngest ages (95 Ma vs c. $120 \mathrm{Ma}$ ) obtained using the $\mathrm{U}-\mathrm{Pb}$ method on tholeiitic magmas ascribed to the HALIP, noting that the U-Pb ages derived from the Wootton igneous complex - an alkaline body - are c. 3 Ma younger (Trettin and Parrish, 1987; Estrada and Henjes-Kunst, 2013). These new c. $95 \mathrm{Ma}$ U-Pb ages provide important constraints on the Strand Fiord pulse of volcanism on Canada's Arctic Margins, along with helping to constrain the timing of the transition between earlier tholeiitic magmas and later alkaline magmas to between 95 and $92 \mathrm{Ma}$.

Despite these two U-Pb ages providing additional constraints into the timing of the Strand Fiord Formation lavas, the paucity of U-Pb ages and the uncertainty in the ArAr ages require that additional $\mathrm{U}-\mathrm{Pb}$ ages be determined in order to provide more control in the timing of the Strand Fiord Formation lavas. Whereas the two new ages reported herein are not statistically distinguishable, they are distinguishable in trace element and Sm-Nd isotopic chemistry. This leads to the conclusion that at least two, but likely three individual batches of magma transited through the South Fiord field area at ca. 95 Ma.

On the basis that sample (13-CK-16) was collected from a dyke which strikes SSE, in line with the general distribution of Stand Fiord Formation lavas (Ricketts et al., 1985; Estrada and Henjes-Kunst, 2004) a tentative conclusion is that SSE-striking dykes in the western part of Axel Heiberg Island are likely feeders for the Strand Fiord 
Formation lavas. These dykes have been assigned to the Cornwall dyke swarm (Buchan and Ernst, 2013).

\subsection{CHAPTER REFERENCES}

Balkwill, H.R., and Haimila, N.E., 1978, K/Ar ages and significance of mafic rocks, Sabine Peninsula, Melville Island, District of Franklin, in Current Research, Part C, Geol. Sur. Can., Paper 78-1C, p. 35-38.

Barker, I.R., Moser, D.E., Kamo, S.L., and Plint, A.G., 2011, High-precision U-Pb zircon ID-TIMS dating of two regionally extensive bentonites: Cenomanian Stage, Western Canada Foreland Basin: Canadian Journal of Earth Sciences, v. 48, no. 2, p. 543-556, doi: 10.1139/E10-042.

Buchan, K.L., and Ernst, R.E., 2013, Diabase dyke swarms of Nunavut, Northwest Territories and Yukon, Canada: Geological Survey of Canada Open File 7464, 2013; 24 pages ( 1 sheet),

Buchan, K.L., and Ernst, R.E., 2006, Giant dyke swarms and the reconstruction of the Canadian Arctic islands , Greenland , Svalbard and Franz Josef Land, in Hanski, E., Mertanen, S., Ramo, T., and Vuollo, J. eds., Dyke Swarms - Time Markers of Crustal Evolution, Taylor \& Francis, p. 27-48.

Cohen, K.M., Finney, S.C., Gibbard, P.L., and Fan, J.-X., 2013, The ICS International Chronostratigraphic Chart: Episodes, v. 36, p. 199-204, doi: 10.1111/j.15023931.1980.tb01026.x.

Corfu, F., Polteau, S., Planke, S., Faleide, J.I., Svensen, H., Zayoncheck, A., and Stolbov, N., 2013, U-Pb geochronology of Cretaceous magmatism on Svalbard and Franz 
Josef Land, Barents Sea Large Igneous Province: Geological Magazine, v. 150, no. 6, p. 1127-1135, doi: 10.1017/S0016756813000162.

Eldrett, J.S., Minisini, D., and Bergman, S.C., 2014, Decoupling of the carbon cycle during Ocean Anoxic Event 2: Geology, v. 42, no. 7, p. 567-570, doi: $10.1130 / \mathrm{G} 35520.1$.

Embry, A.F., and Beauchamp, B., 2008, Chapter 13: Sverdrup Basin, in Miall, A.D. ed., Sedimentary Basins of the World: v. 5, p. 451-471.

Embry, A.F., and Osadetz, K.G., 1988, Stratigraphy and tectonic significance of Cretaceous volcanism in the Queen Elizabeth Islands, Canadian Arctic Archipelago: Canadian Journal of Earth Sciences, v. 25, p. 1209-1219.

Estrada, S., 2014, Geochemical and $\mathrm{Sr}-\mathrm{Nd}$ isotope variations within Cretaceous continental flood-basalt suites of the Canadian High Arctic, with a focus on the Hassel Formation basalts of northeast Ellesmere Island: International Journal of Earth Sciences, doi: 10.1007/s00531-014-1066-x.

Estrada, S., and Henjes-Kunst, F., 2013, 40Ar-39Ar and U-Pb dating of Cretaceous continental rift-related magmatism on the northeast Canadian Arctic margin: Zeitschrift der Deutschen Gesellschaft für Geowissenschaften, v. 164, no. 1, p. 107130, doi: 10.1127/1860-1804/2013/0005.

Estrada, S., and Henjes-Kunst, F., 2004, Volcanism in the Canadian High Arctic related to the opening of the Arctic Ocrean: Z. dt. geol. Ges, v. 154, no. 4, p. 579-603.

Evenchick, C.A., Davis, B.J., Bedard, J.H., Hayward, N., and Friedman, R.M., 2014, Ages of magmatism in the central Sverdrup Basin, Canadian Arctic Islands, from volcanigenic rocks, geochronology, and paleo-depths of saucer-shaped sills, in 
Geological Society of America Abstracts with Programs, p. 567.

Evenchick, C.A., Davis, W.J., Bédard, J.H., Hayward, N., and Friedman, R.M., 2015, Evidence for protracted High Arctic large igneous province magmatism in the central Sverdrup Basin from stratigraphy, geochronology, and paleodepths of saucer-shaped sills: Geological Society of America Bulletin, p. B31190.1, doi: 10.1130/B31190.1.

Gerstenberger, H., and Haase, G., 1997, A highly effective emitter substance for mass spectrometric $\mathrm{Pb}$ isotope ratio determinations: Chemical Geology, v. 136, p. 309312.

Grogan, P., Nyberg, K., Fotland, B., Myklebust, R., Dahlgren, S., and Riis, F., 2000, Cretaceous magmatism south and east of Svalbard: Evidence from seismic reflection and magnetic data: Polarforschung, v. 68, no. May 1999, p. 25-34.

Heaman, L.M., and LeCheminant, A.N., 1993, Paragenesis and U-Pb systematics of baddeleyite (Zr02): Chemical Geology, v. 110, p. 95-126.

Hou, G., 2012, Mechanism for three types of mafic dyke swarms: Geoscience Frontiers, v. 3, no. 2, p. 217-223, doi: 10.1016/j.gsf.2011.10.003.

Jackson, M.P.A., and Harrison, J.C., 2006, An allochthonous salt canopy on Axel Heiberg Island, Sverdrup Basin, Arctic Canada: Geology, v. 34, no. 12, p. 10451048.

Jackson, M.P., and Harrison, J.C., 2010, Geology, Strand Fiord-Expedition Fiord Area, Western Axel Heiberg Island, Nunavut.: Geological Survey of Canada, Map 2157A, scale 1:100,000.

Jaffey, A.H., Flynn, K.F., Glendenin, L.E., Bentley, W.C., and Essling, A.M., 1971, 
Precision measurement of half-lives and specific activities of $235 \mathrm{U}$ and $238 \mathrm{U}$ :

Physical Review, v. 4, p. 1889-1906.

Jerram, D.A., and Widdowson, M., 2005, The anatomy of Continental Flood Basalt Provinces: geological constraints on the processes and products of flood volcanism: Lithos, v. 79, no. 3-4, p. 385-405, doi: 10.1016/j.lithos.2004.09.009.

Jowitt, S.M., Williamson, M., and Ernst, R.E., 2014, Geochemistry of the 130 to $80 \mathrm{Ma}$ Canadian High Arctic Large Igneous Province (HALIP) Event and Implications for Ni-Cu-PGE Prospectivity: Economic Geology, v. 109, no. 2, p. 281-307.

Kingsbury, C.G., Ernst, R.E., Cousens, B.L., and Williamson, M.-C., 2016, The High Arctic LIP in Canada: Trace element and Sm-Nd Isotopic evidence for the role of mantle heterogeneity and crustal assimilation: Norwegian Journal of Geology, v. 96, no. 2 , p. 13-33.

Kingsbury, C.G., Williamson, M.-C., Day, S.J., and McNeil, R.J., 2014, The 2013 Isachsen expedition to Axel Heiberg Island, Nunavut, Canada: a field report: Geological Survey of Canada, Open File 7539, 2014; 6 pages (1 sheet), doi:10.4095/293842, .

Kontak, D.J., Jensen, S.M., Dostal, J., Archibald, D.A., and Kyser, T.K., 2001, Cretaceous mafic dyke swarm, Peary Land, Northernmost Greenland: Geochronology and petrology: Canadian Mineralogist, v. 39, no. 4, p. 997-1020, doi: 10.2113/gscanmin.39.4.997.

Koryakin, Y. V., and Shipilov, E. V., 2009, Geochemical specifics and 40Ar/39Ar age of the basaltoid magmatism of the Alexander Land, Northbrook, Hooker, and Hayes islands (Franz Josef Land Archipelago): Doklady Earth Sciences, v. 425, no. 1, p. 
260-263, doi: 10.1134/S1028334X09020196.

Krogh, T.E., 1973, A low contamination method for hydrothermal decomposition of zircon and extraction of $\mathrm{U}$ and $\mathrm{Pb}$ for isotopic age determinations: Geochimica et Cosmochimica Acta, v. 37, p. 485-494.

Ludwig, K.R., 2003, User's manual for Isoplot 3.00: A geochronological toolkit for Microsoft Excel.: Berkeley Geochronology Center, Special Publication No. 4, p. 71.

Nejbert, K., Krajewski, K.P., Dubinska, E., and Pécskay, Z., 2011, Dolerites of Svalbard, north-west Barents Sea Shelf: age, tectonic setting and significance for geotectonic interpretation of the High-Arctic Large Igneous Province: Polar Research, v. 30, no. 0, p. 1-24, doi: 10.3402/polar.v30i0.7306.

Oakey, G.N., and Saltus, R.W., 2016, Geophysical analysis of the Alpha-Mendeleev ridge complex: Characterization of the High Arctic Large Igneous Province: Tectonophysics, doi: 10.1016/j.tecto.2016.08.005.

Ogg, J.G., Ogg, G.M., and Gradstien, F.M., 2016, A Concise Geologic Time Scale: Elsevier.

Pearce, J.A., and Norry, M.J., 1979, Petrogenetic implications of Ti, Zr, Y, and Nb variations in volcanic rocks: Contributions to Mineralogy and Petrology, v. 69, no. 1, p. 33-47, doi: 10.1007/BF00375192.

Polteau, S., Hendriks, B.W.H., Planke, S., Ganerød, M., Corfu, F., Faleide, J.I., Midtkandal, I., Svensen, H.S., and Myklebust, R., 2016, The Early Cretaceous Barents Sea Sill Complex: Distribution, 40Ar/39Ar geochronology, and implications for carbon gas formation: Palaeogeography, Palaeoclimatology, Palaeoecology, v. 441, p. 83-95, doi: 10.1016/j.palaeo.2015.07.007. 
Ricketts, B., Osadetz, K.G., and Embry, A.F., 1985, Volcanic style in the Strand Fiord Formation (Upper Cretaceous), Axel Heiberg Island, Canadian Arctic Archipelago: Polar Research, v. 3, no. 1, p. 107-122, doi: 10.1111/j.1751-8369.1985.tb00497.x.

Saltus, R.W., Miller, E.L., Gaina, C., and Brown, P.J., 2011, Chapter 4: Regional magnetic domains of the Circum-Arctic: A framework for geodynamic interpretation: Geological Society Memoir, v. 35, p. 49-60, doi: 10.1144/M35.4.

Saumur, B.-M., Dewing, K., and Williamson, M.-C., 2016, Architecture of the Canadian portion of the High Arctic Large Igneous Province and implications for magmatic Ni-Cu potential: Canadian Journal of Earth Sciences, v. 53, p. 528-542.

Söderlund, U., Ibanez-Mejia, M., El Bahat, A., Ernst, R.E., Ikenne, M., Soulaimani, A., Youbi, N., Cousens, B.L., El Janati, M., and Hafid, A., 2013, Reply to Comment on " $\mathrm{U}-\mathrm{Pb}$ baddeleyite ages and geochemistry of dolerite dykes in the Bas-Drâa inlier of the Anti-Atlas of Morocco: Newly identified 1380Ma event in the West African Craton” by André Michard and Dominique Gasquet: Lithos, v. 174, p. 101-108, doi: 10.1016/j.lithos.2013.04.003.

Söderlund, U., and Johansson, L., 2002, A simple way to extract baddeleyite (ZrO2): Geochemistry, Geophysics, Geosystems, v. 3, no. 2, p. 1-7.

Stevens, R.D., Delabio, R.N., and Lachance, G.R., 1982, K-Ar Isotopic Ages, Report 16, Paper 82-2, in Age determinations and geological studies, Geological Survey of Canada.

Tarduno, J.A., Brinkman, D.B., Renne, P.R., Cottrell, R.D., Scher, H., and Castillo, P., 1998, Evidence for Extreme Climatic Warmth from Late Cretaceous Arctic Vertebrates: Science, v. 282, no. 5397, p. 2241-2243, doi: 
10.1126/science.282.5397.2241.

Tegner, C., Storey, M., Holm, P.M., Thorarinsson, S.B., Zhao, X., Lo, C.-H., and Knudsen, M.F., 2011, Magmatism and Eurekan deformation in the High Arctic Large Igneous Province: 40Ar-39Ar age of Kap Washington Group volcanics, North Greenland: Earth and Planetary Science Letters, v. 303, no. 3-4, p. 203-214, doi: 10.1016/j.eps1.2010.12.047.

Thórarinsson, S.B., Holm, P.M., Tappe, S., Heaman, L.M., and Tegner, C., 2011, Late Cretaceous - Palaeocene continental rifting in the High Arctic : $\mathrm{U}-\mathrm{Pb}$ geochronology of the Kap Washington Group volcanic sequence, North Greenland: Journal of the Geological Society, v. 168, p. 1093-1106, doi: 10.1144/001676492011-018.

Thórarinsson, S.B., Söderlund, U., Døssing, A., Holm, P.M., Ernst, R.E., and Tegner, C., 2015, Rift magmatism on the Eurasia basin margin : $\mathrm{U}-\mathrm{Pb}$ baddeleyite ages of alkaline dyke swarms in North Greenland: Journal of the Geological Society, v. 172, no. 6, doi: 10.1144/jgs2015-049.

Thorsteinsson, R., and Tozer, E.T., 1971, Geology, Middle Fiord, District of Franklin: Geological Survey of Canada, Map 1299A, scale 1:250,000.

Trettin, H.P., and Parrish, R., 1987, Late Cretaceous bimodal magmatism, northern Ellesmere Island: isotopic age and origin: Canadian Journal of Earth Sciences, v. 24, p. 257-265.

Villeneuve, M., and Williamson, M.-C., 2006, 40Ar-39Ar dating of mafic magmatism from the Sverdrup Basin Magmatic Province, in Scott, R.A. and Thurston, D.K. eds., Proceedings of the Fourth International Conference on Arctic Margins, p. 206- 
215.

Williamson, M.-C., 1988, The Cretaceous igneous province of the Sverdrup Basin, Canadian Arctic: Field relations and petrochemical studies: Ph.D. thesis, Dalhousie University, Halifax, Nova Scotia, 417 p.

Zindler, A., and Hart, S., 1986, Chemical Geodynamics: Annual Review of Earth and Planetary Sciences, v. 14, no. 1, p. 493-571, doi:

10.1146/annurev.ea.14.050186.002425. 


\section{Chapter 5 \\ Conclusions:}

\subsection{REVIEW OF THESIS OBJECTIVES:}

This thesis has explored the Canadian portion of the High Arctic Large Igneous Province (HALIP) from field, geochemical and geochronology aspects through the lens of exposed intrusions and lava flows in the South Fiord region of Axel Heiberg Island along with lavas from Camp Five Creek and Geodetic Hills localities, also on Axel Heiberg Island (Chapter 1, Fig. 1.5). Based on these investigations presented herein, I conclude the following:

\subsection{FIELD AND REMOTE SENSING (Chapter 2):}

- Geologic investigation in the South Fiord region demonstrates that a highly remote field area Axel Heiberg Island can be mapped effectively using a combination of field and remote sensing techniques - especially using SPOT-6 which allows for the capability to not only sense general rock type information, but also outcrop characteristics. A map was produced showing the mafic intrusions (dykes and sills) and Isachsen mafic volcanic rocks in the region (Fig. 2.17), and the geometric characteristics of each mafic unit were summarized in Table 2.2.

- The South Fiord field area contains a network of mafic sills that range from $2-50$ $\mathrm{m}$ (averaging $5-10 \mathrm{~m}$ ) along with dykes which trend SE - SSE that belong to the 
regionally extensive Cornwall swarm identified by Buchan and Ernst (2013). The identification of many sill bodies and a dyke swarm in a previously unmapped and geographically small area portends that the plumbing system of the HALIP is more complex than previously recognized and matches the complexity recently observed in other areas of the HALIP (e.g. Saumur et al., 2016; Williamson et al., 2016; Evenchick et al., 2015), and in other LIP events (Ernst, 2014). With the exception of the $50 \mathrm{~m}$ sill, the relatively thin sills in the South Fiord area further imply low magmatic flux within these thin sills.

- The sandstone-shale sedimentary sequence well preserved at Cuesta Ridge, South Fiord region, marks a succession of marginal marine facies that, when combined with the two newly mapped subaerial lavas suggest the lavas erupted in a coastal plain environment, which is supportive of recent suggestions for a passive margin at the time of HALIP emplacement in the Sverdrup basin (Hadlari et al., 2016).

\subsection{GEOCHEMISTRY AND SM-ND ISOTOPES (CHAPTER 3)}

- Petrographic analysis of South Fiord intrusive samples typically reveal diabasic and sub-ophitic textures consisting of clinopyroxene and plagioclase feldspar, the latter often displaying evidence of sericitization, but the clinopyroxene is often left unaltered. The sample collected from the upper part of a $>50 \mathrm{~m}$ gabbroic sill (Chapter 2, Table 2.2; sill no. S10) shows plagioclase and clinopyroxene with trace amounts of free quartz. Isachsen Formation lavas display porphyritic textures consisting of mm-sized plagioclase phenocrysts set in a groundmass of 
plagioclase, clinopyroxene and glass in which some samples show evidence of sericitic alteration.

- Based on chemical systematics, all samples studied herein are tholeiitic. Furthermore, Isachsen Formation lavas as well as all South Fiord intrusive samples, with the exception of one, are chemically equivalent to subalkaline basalts. The lone exception was the sample collected from the upper portion of the sill mentioned above which is chemically equivalent to subalkaline basaltic andesite.

- Trace-element (e.g. mantle normalized $\mathrm{Tb} / \mathrm{Yb}, \mathrm{REE}$ ) and $\mathrm{Nd}$ - isotopic results indicate a homogenous upper asthenospheric source coupled with a strong Sverdrup Basin assimilation signature (10 - 20\% crustal assimilation) for the South Fiord intrusives. These magmatic and crustal signatures, in turn appear to match ca. 90-100 Ma Strand Fiord Formation lavas, and are distinct from the older ca. $125 \mathrm{Ma}$ Isachsen Formation mafic volcanic rocks, which lack a crustal contamination signature.

- Using the same trace-element and isotopic plots, the Isachsen Formation lavas likely originated from a chemically heterogeneous mantle source, which partially melted over a wide range of depth including some melting in the garnet peridotite field, and featuring a weak to non-existent crustal assimilation signature. 
- On the basis of elevated $\mathrm{Ba} / \mathrm{Th}$ (up to 200 ) and $\mathrm{Ba} / \mathrm{Nb}$ (up to 40 ) in some of the Isachsen Formation lavas, it is suggested that the heterogeneous mantle tapped by Isachsen Formation lavas may include a subducted sediment component that was derived from subduction zones ancestral to the present-day Aleutian subduction zone and incorporated into the mantle plume head, potentially similar to what has been proposed for the plume which is feeding Hawai'i volcanism (Huang et al., 2009). A recent complementary study using geophysical methods suggests the presence of a subducted slab beneath Canada's Arctic Islands and Greenland at the time HALIP was active (Shephard et al., 2016).

- The high $\mathrm{CaO}$ and $\mathrm{Na}_{2} \mathrm{O}$ in certain samples of the Isachsen Formation lavas in concert with anomalously low $\mathrm{SiO}_{2}$ may also indicate that these particular rocks were interacting with the extensive evaporite diapirs derived from the Carboniferous Otto Fiord Formation at depth.

- The crustal contamination signature of the South Fiord intrusions along with the ca. 95 Ma Strand Fiord Formation flood basalts and the lack thereof in the ca. 125 Ma Isachsen Formation lavas may relate to the frequency with which the two HALIP pulses erupted lavas. The higher frequency of eruptions within the Strand Fiord Formation lavas inferred based on the lack of sedimentary rocks between the majority of the flows (Williamson, 1988) may have maintained a thermal anomaly within the Sverdrup Basin between eruptions, promoting greater contamination efficiency. 


\subsection{U-PB GEOCHRONOLOGY (CHAPTER 4)}

- U-Pb baddeleyite ages of $95.18 \pm 0.35 \mathrm{Ma}$ and 95.56 $\pm 0.24 \mathrm{Ma}$ were obtained from two intrusions in South Fiord, and along with their geochemistry, demonstrate that these intrusions (the South Fiord intrusions) are part of the plumbing system which fed the Cenomanian Strand Fiord Formation basaltic lavas rather than the older Isachsen Formation basaltic lavas. The lavas therefore mapped in South Fiord within the Isachsen Formation stratigraphic succession (Chapter 2, Fig. 2.17) are not linked with the South Fiord intrusive bodies despite being proximal to these flows.

- The $95 \mathrm{Ma}$ age determinations represent the youngest ages obtained from tholeiitic magmas ascribed to HALIP and are 3 Ma older than the alkaline magmas which form the 92 Ma Wootton Igneous Complex, of northern Ellesmere Island, providing a new robust constraint on the timing of the transition from tholeiitic to alkaline magmatism in the Canadian High Arctic (Trettin and Parrish, 1987; Estrada and Henjes-Kunst, 2013).

- One of the two dated samples was obtained from a dyke that strikes SSE (mapped in Chapter 2). This dyke parallels a swarm of dykes designated as the Cornwall dyke swarm by Buchan and Ernst (2013) that occur on the western portion of Axel Heiberg Island. The SE-SSE orientation of these dykes parallels the major axis of the oblong areal extent of the Strand Fiord Formation (Fig. 1a in Estrada 
and Henjes-Kunst, 2013; Ricketts et al., 1985). This suggests that these SE- SSE trending dykes concentrated along the western part of Axel Heiberg Island form the plumbing system of the 95 Ma Strand Fiord Formation lavas, rather than the radiating Queen Elizabeth Islands swarm associated with ca. $125 \mathrm{Ma}$ Isachsen Formation magmatism.

\subsection{DEMONSTRATED INTEGRATION}

A clear framework towards deciphering the geochemical trends of the mafic intrusions and lava flows exposed at South Fiord (Chapter 3) first necessitated detailed mapping of the igneous units that intruded into, along with the lavas that flowed atop, the ca. 125 Ma Isachsen Formation sediments (Chapter 2). The lack of any feeder systems connecting the lava flows and intrusions exposed at South Fiord (Chapter 2) in concert with the geochemical distinctions thereof presented in Chapter 3 along with high precision $95 \mathrm{Ma} \mathrm{U}-\mathrm{Pb}$ age determinations from South Fiord intrusions in Chapter 4, demonstrate a genetic link between the South Fiord intrusions and the younger $95 \mathrm{Ma}$ pulse of the Strand Fiord Formation basalts rather than with the older pulse of volcanism associated with the c. 125 Ma Isachsen Formation. This thesis therefore, provided a detailed examination of a small portion of the plumbing system along with lava flows associated with a regionally extensive Cretaceous magmatic event that affected Canada's Queen Elizabeth Islands: the Canadian component of the High Arctic Large Igneous Province (HALIP). 


\subsection{CHAPTER REFERENCES}

Buchan, K.L., and Ernst, R.E., 2013, Diabase dyke swarms of Nunavut, Northwest Territories and Yukon, Canada: Geological Survey of Canada Open File 7464, 2013; 24 pages (1 sheet).

Ernst, R.E., 2014, Large Igneous Provinces: Cambridge University Press, Cambridge, $\mathrm{UK}, 653 \mathrm{p}$.

Estrada, S., and Henjes-Kunst, F., 2013, 40Ar-39Ar and U-Pb dating of Cretaceous continental rift-related magmatism on the northeast Canadian Arctic margin: Zeitschrift der Deutschen Gesellschaft für Geowissenschaften, v. 164, no. 1, p. 107130, doi: 10.1127/1860-1804/2013/0005.

Evenchick, C.A., Davis, W.J., Bédard, J.H., Hayward, N., and Friedman, R.M., 2015, Evidence for protracted High Arctic large igneous province magmatism in the central Sverdrup Basin from stratigraphy, geochronology, and paleodepths of saucer-shaped sills: Geological Society of America Bulletin, p. B31190.1, doi: 10.1130/B31190.1.

Hadlari, T., Midwinter, D., Galloway, J.M., Dewing, K., and Durbano, A.M., 2016, Mesozoic rift to post-rift tectonostratigraphy of the Sverdrup Basin, Canadian Arctic: Marine and Petroleum Geology, v. 76, p. 148-158, doi: 10.1016/j.marpetgeo.2016.05.008.

Huang, S., Abouchami, W., Blichert-Toft, J., Clague, D.A., Cousens, B.L., Frey, F.A., and Humayun, M., 2009, Ancient carbonate sedimentary signature in the Hawaiian plume: Evidence from Mahukona volcano, Hawaii: Geochemistry Geophysics Geosystems, v. 10, no. 8, doi: 10.1029/2009GC002418. 
Ricketts, B., Osadetz, K.G., and Embry, A.F., 1985, Volcanic style in the Strand Fiord Formation (Upper Cretaceous), Axel Heiberg Island, Canadian Arctic Archipelago: Polar Research, v. 3, no. 1, p. 107-122, doi: 10.1111/j.1751-8369.1985.tb00497.x.

Saumur, B.-M., Dewing, K., and Williamson, M.-C., 2016, Architecture of the Canadian portion of the High Arctic Large Igneous Province and implications for magmatic Ni-Cu potential: Canadian Journal of Earth Sciences, v. 53, p. 528-542.

Shephard, G.E., Trønnes, R.G., Spakman, W., Panet, I., and Gaina, C., 2016, Evidence for slab material under Greenland and links to Cretaceous High Arctic magmatism: Geophysical Research Letters, v. 43, p. 1-10, doi: 10.1002/2016GL068424.

Trettin, H.P., and Parrish, R., 1987, Late Cretaceous bimodal magmatism, northern Ellesmere Island: isotopic age and origin: Canadian Journal of Earth Sciences, v. 24, p. 257-265.

Williamson, M.-C., 1988, The Cretaceous igneous province of the Sverdrup Basin, Canadian Arctic: Field relations and petrochemical studies: Ph.D. thesis, Dalhousie University, Halifax, Nova Scotia, 417 p.

Williamson, M.-C., Saumur, B.-M., and Evenchick, C.A., 2016, HALIP volcanicintrusive complexes, Axel Heiberg Island, Nunavut in Williamson, M.-C., ed: Report of Activities for High Arctic Large Igneous Province (HALIP)-GEM 2 Western Arctic Region Project: Bedrock Mapping and Mineral Exploration: Geological Survey of Canada Open File 7950, p. 14-26, doi: 10.4095/297487. 


\section{Appendix 1: Field Data}

\section{Field Notes for the foot traverse area}

\section{Uncorrected S/D = strike and dip not corrected for magnetic}

declination

\begin{tabular}{|c|c|c|c|c|}
\hline Date & GSC_StalD & Lat & Long & Descr \\
\hline 11-Jul-13 & 13WJA_01 & 79.3662 & -93.5390 & $\begin{array}{l}\text { Subcrop/outcrop of fine gabbroic intrusion, } \\
\text { fresh surfaces black to dark-grey in colour } \\
\text { with } 1-2 \mathrm{~mm} \text { sized crystals in a phaneritic } \\
\text { groundmass. No obvious phoenocrysts. } \\
\text { Outcrop weathers to red-orange colour. } \\
\text { Portions of the outcrop appear to weather } \\
\text { into mm-sized dark-greenish-grey gruss. }\end{array}$ \\
\hline \multirow[t]{4}{*}{ 13-Jul-13 } & 13WJA_Q002 & 79.3653 & -93.5497 & $\begin{array}{l}\text { Near Contact with anhydrite dome. } \\
\text { Aphanitic basaltic rock with mm-sized } \\
\text { phenocrysts of buff-coloured plagioclase } \\
\text { perhaps signifying alteration. Extensive } \\
\text { fracture network filled with anhydrite within } \\
1-2 \mathrm{~m} \text { of the dome. One well-developed } \\
\sim \text { metre wide subvertical colum with } \\
\text { transverse fractures. }\end{array}$ \\
\hline & 13WJA_Q003A & 79.3655 & -93.5483 & $\begin{array}{l}\text { Outcrop of massive fractured dark grey to } \\
\text { black basaltic rock. Weathers to burnt-red } \\
\text { and orange. Some surfaces impart a } \\
\text { greenish hint perhaps signifying chloritic } \\
\text { alteration. }\end{array}$ \\
\hline & 13WJA_Q004 & 79.3664 & -93.5413 & $\begin{array}{l}\text { Station location by the creekside, however } \\
\text { the intended target is the fall-line direction } \\
\text { that delimits contact between burnt- } \\
\text { red(mafic) and light green outcrop on top } \\
\text { of inaccessible ridge just west. }\end{array}$ \\
\hline & 13WJA_Q005 & 79.3672 & -93.5382 & $\begin{array}{l}\text { Head of "Chimney Gossan" Contact } \sim 50 \\
\mathrm{~m} \text { upslope of ridge to west of Anhydrite } \\
\text { dome to right and what appears to be a } \\
\text { single well-formed } \sim 2-5 \mathrm{~m} \text { wide column of } \\
\text { mafic rock.column is sub-verticle in plan } \\
\text { view though could not deduce any dip. } \\
\text { Perhaps another column much less } \\
\text { developed is present and } \sim 2 \mathrm{~m} \text { wide. }\end{array}$ \\
\hline 15-Jul-13 & 13WJA_Q006 & 79.3740 & -93.6267 & $\begin{array}{l}\text { Loc: West side of "hip wadder creek" on } \\
\text { front side of mound behind Camp facing } \\
\text { river. Sig: Contact between mafic rock and } \\
\text { isachesen sandstone. Crude columnar } \\
\text { jointing. } 1-2 \text { mm, medium grained } \\
\text { phaneritic mafic rock. UNCORRECTED } \\
\text { S/D taken on columns } 315 / 50 \text {. }\end{array}$ \\
\hline
\end{tabular}




\begin{tabular}{|c|c|c|c|c|}
\hline & 13WJA_Q007 & 79.3767 & -93.6315 & $\begin{array}{l}\text { Loc: West-facing slope of Backyard Knoll } \\
\text { facing Drinkwater creek. Obs: Small scree } \\
\text { field }(\sim 10 \times 10 \mathrm{~m}) \text { of large } 10 \text { s of } \mathrm{cm} \text {-sized } \\
\text { dark grey showing dabasic texture. } \\
\text { Localised area in a light orange } \\
\text { weathering field of distinctively smaller } \\
\text { size. Localized field perhaps means } \\
\text { outcrop relatively close to surface? }\end{array}$ \\
\hline & 13WJA_Q008 & 79.3791 & -93.6227 & $\begin{array}{l}12 \times 8 \times 7 \mathrm{~cm} \text { boulder in stream outwash of } \\
\text { vesicular basalt "top" grading to massive } \\
\text { over } 1 \mathrm{~cm} \text {.Brownish-grey in colour. } \\
\text { Significance: Upstream from this location } \\
\text { exists a LIKELY lava flow. Perhaps the } \\
\text { horizontal igneous layers are Flows rather } \\
\text { than sills? }\end{array}$ \\
\hline & 13WJA_Q009 & 79.3815 & -93.6239 & $\begin{array}{l}\text { Loc: High above hipwader creek.Can see } \\
\text { Stand Fiord Fm on Triangle penninsula } \\
\text { and top of anhydrite dome. Obs: Diabasic } \\
\text { texture with laths of plagioclase } 1-2 \mathrm{~mm} \text { in } \\
\text { size and dark grey in colour. M-scale } \\
\text { columnar jointing sub-horizontal. } \\
\text { UNCORRECTED S/D 285/25. }\end{array}$ \\
\hline \multirow[t]{5}{*}{ 16-Jul-13 } & & & & $\begin{array}{l}\text { Preliminary thoughts: Based on attitude } \\
\text { measurements made on the top of a } \\
\text { columnin a relatively isolated exposure, } \\
\text { (13CGK009) showing a dip to the } \\
\text { northeast; further, based on the geological } \\
\text { map of Thorsteinsson \& Tozer (1971) } \\
\text { showing estimated dip to the southwest } \\
\text { on a SW limb of an anticine cored by an } \\
\text { anhydrite dom, leads me to suggest that } \\
\text { the long penatrative ridge which cross- } \\
\text { cuts hip-wader creekis the topographic } \\
\text { expression of a tectonically tilted dyke. the } \\
\text { sandstone then could be a large xenolith, }\end{array}$ \\
\hline & ??? & 79.3713 & -93.6258 & $\begin{array}{l}\text { Contact between mafic tabular intrusion } \\
\text { and fragmental (calc-silicate?) }\end{array}$ \\
\hline & 13WJA_C002 & 79.3717 & -93.6239 & $\begin{array}{l}\text { Massive medium grey sandstone } \\
\text { weathers to light medium orange (ochure). } \\
\text { Scree covered in lichen. Quartz } \\
\text { arenitemassive cross-stratification. } \\
\text { UNCORRECTED S/D on poor-quality bed: } \\
\text { 335/10 NE }\end{array}$ \\
\hline & 13WJA_C004A & 79.3742 & -93.6120 & $\begin{array}{l}\text { On top of Near ridge east of camp. Mafic } \\
\text { igneous dyke outcrop showing columnar } \\
\text { jointing dipping NE. Measured width } \sim 5 \mathrm{~m} \text {. } \\
\text { Fresh colour: dark grey weathering to dark } \\
\text { orange/red/grey. }\end{array}$ \\
\hline & 13WJA_C005 & 79.3705 & -93.6057 & $\begin{array}{l}\text { Near seaward end of ridge top that } \\
\text { CGK015 refers to }\end{array}$ \\
\hline 17-Jul-13 & 13WJA_C006 & 79.3684 & -93.6022 & $\begin{array}{l}\text { Control point. Base of tilted dyke at the far } \\
\text { end of dyke from camp. Scree slope and } \\
\text { no outcrop. Follow trend of 13CGK015 } \\
\text { and 13CGK016. Stream cut }\end{array}$ \\
\hline
\end{tabular}




\begin{tabular}{|c|c|c|c|c|}
\hline & 13WJA_C007 & 79.3708 & -93.5963 & $\begin{array}{l}\text { 2-3 m thich tabular intrusion of diabase. } \\
\text { Column sets dipping NW, which appears } \\
\text { to be roughly concordant with the } \\
\text { stratigraphy of sedimentary rocks (of the } \\
\text { geologic map) Sill potentially. Columns } \\
\text { dipping in opposite direction from the dyke } \\
\text { ridge at } 3 \text { previous stations. } \\
\text { UNCORRECTED S/D } 240 / 30 \mathrm{~W}\end{array}$ \\
\hline & 13WJA_C008 & 79.3722 & -93.3931 & $\begin{array}{l}\sim 5 \mathrm{~m} \text { wide mafic tabular intrusion. Dip } \\
\text { consistent with a sill tilted during tectonism } \\
\text { as shown in geological map of } \\
\text { Thorstiensson (1976). } \\
\text { Massive/homogenous. UNCORRECTED } \\
\text { S/D Colums 225/45 }\end{array}$ \\
\hline & 13WJA_C009 & 79.3743 & -93.5867 & $\begin{array}{l}\text { High point on ridge overlookingsouth } \\
\text { Fiord. Likely highest station. Crumply } \\
\text { subcrop of mafic intrusio. Medium grained } \\
\text { phaneritic groundmass.Margins not well } \\
\text { exposed. Medium grey-fresh, brown } \\
\text { weathered. }\end{array}$ \\
\hline & 13WJA_C010 & 79.3745 & -93.5969 & $\begin{array}{l}\text { On covered contact between medium } \\
\text { grainec sandstone w/mafic igneous unit. } \\
\text { Appears tabular but hard to deduce owing } \\
\text { to frost-heaving and very little stucture. } \\
\text { Medium grey when fresh, weathers to } \\
\text { dark-medium brown. "West Stooge" }\end{array}$ \\
\hline \multirow[t]{3}{*}{ 19-Jul-13 } & 13WJA_C015 & 79.3765 & -93.6610 & $\begin{array}{l}\text { Loc: W-E trending tabular intrusion } \\
\text { adjacent to Cascade Gossan. Thickness } \\
\text { indeterminate. Chilled margin medium } \\
\text { grey, weathering to medium } \\
\text { orange/brown. Centre colour dark grey } \\
\text { weathering to dark broun. } \\
\text { UNCORRECTED S/D (3)30/25 }\end{array}$ \\
\hline & 13WJA_C016 & 79.3782 & -93.6685 & $\begin{array}{l}\text { Outcrop of beige sandstone along banks } \\
\text { of Side river opposite Cascades Gossan } \\
\text { upstream to "columnar jointed knickpoints. } \\
\text { Purpose to ascertain orientation of tabular } \\
\text { intrusion in area. UNCORRECTED S/D on } \\
\text { ss bedding plane } 80 / 20 \mathrm{~S}\end{array}$ \\
\hline & 13WJA_C017 & 79.3821 & -93.6657 & $\begin{array}{l}\text { O/C Characteristics: intact but rubbly } \\
\text { appearance Crude columns (?) dip steeply } \\
\text { to the NE. Thickness } \sim 5 \mathrm{~m} \text {. This o/c is on } \\
\text { strike with and the psudo colums dip in the } \\
\text { same directipn as the dyke ridge located } \\
\text { east of camp location. Dark Grey-black } \\
\text { when fresh, weathering to medium } \\
\text { brown/orange aphanitic mafic rock. Sub- } \\
\text { mm-sized phenocrysts of } 15-20 \% \\
\text { abundance. Some rocks contain }<2 \mathrm{~mm} \\
\text { sized amygdalized vesicles. }\end{array}$ \\
\hline
\end{tabular}




\begin{tabular}{|c|c|c|c|c|}
\hline & 13WJA_C018 & 79.3832 & -93.6693 & $\begin{array}{l}\text { HIGHEST STATION!!!! Opposite } \\
\text { drinkwater creek. Medium grey to dark } \\
\text { grey tabular mafic unit. Columns dip } \\
\text { broadly to the southwest. Nearly } \\
\text { concordant to -C016. Weathers to } \\
\text { brownish purple. Thickness } \sim 180 \mathrm{~cm} \text { with } \\
\text { a distinct zone } 60 \mathrm{~cm} \text { from the top of } \\
\text { apparent } 2-3 \mathrm{~cm} \text { laths of plagioclase } \\
\text { phenocrysts. Is it meerly a weathering } \\
\text { effect that is bringing it out in this region or } \\
\text { is itsomething else? } 160 \mathrm{~cm} \text { from the top } \\
\text { are zones of mm-sized vesicles. }\end{array}$ \\
\hline \multirow[t]{4}{*}{ 20-Jul-13 } & 13WJA_C019 & 79.3682 & -93.6587 & $\begin{array}{l}\text { "Pseudo gossan" visible to west on side of } \\
\text { ridge next to camp. } 8 \mathrm{~m} \times 5 \mathrm{~m} \text { wide zone of } \\
\text { yellow-greenish yellow surficial alteration } \\
\text { in a heavily fractured host rock "breccia" }\end{array}$ \\
\hline & 13WJA-C020 & 79.3773 & -93.6912 & $\begin{array}{l}\text { Base of Stratigraphic section - Basal } \\
\text { Sandstone }\end{array}$ \\
\hline & 13WJA-C021 & 79.3773 & -93.6937 & Flow 1 \\
\hline & 13WJA-C022 & 79.3775 & -93.6944 & Flow 2 \\
\hline
\end{tabular}

\section{Sample collection for the foot traverse area}

\begin{tabular}{|l|l|l|}
\hline Date & GSC_StaID & Samples \\
\hline 11-Jul-13 & 13WJA_01 & 13CK001: Sample taken from $30 \mathrm{~m}$ from E. Fiord Dome \\
\hline & & 13CK002: ibid \\
\hline 13-Jul-13 & 13WJA_Q002 & 13CK003: Thin Section \\
\hline & & 13CK004: Representative \\
\hline & & 13CK005: Whole Rock \\
\hline & & 13WJA_Q002A \\
\hline & & 13CK006: Whole Rock \\
\hline & & 13CK007: RE/TE \\
\hline & 13WJA_Q004 & 13WJA_Q003A \\
\hline & & 13CK008: Thin Section \\
\hline & & 13CK009: Rep \\
\hline & & 13WJA_Q004A: Representative \\
\hline & 13WJA_Q005 & NO SAMPLES \\
\hline 15-Jul-13 & 13WJA_C011 & 13CK010: Thin Section \\
\hline & & 13CK011: Whole Rock \\
\hline & & 13CK012: Representative \\
\hline & & 13CK013: Age \\
\hline & & 13WJA_Q006 \\
\hline & & 13CK014: Age/Thin section \\
\hline & & 13CK015: Age/Thin Section \\
\hline & & 13CK016: Omni \\
\hline & & 13WJA_Q007A \\
\hline & & 13CK017: Representative \\
\hline & & \\
\hline
\end{tabular}




\begin{tabular}{|c|c|c|}
\hline & & 13WJA_Q008A: Representative \\
\hline & 13WJA_C014 & $13 \mathrm{CK} 018$ \\
\hline & & 13WJA_Q009A \\
\hline \multirow[t]{7}{*}{ 16-Jul-13 } & & $13 \mathrm{CK} 019$ \\
\hline & & 13CK020-grey unit \\
\hline & & 13CK021-chilled margin \\
\hline & 13WJA_C002 & $13 \mathrm{CK} 022$ \\
\hline & 13WJA_C004A & 13CK023: Chilled margin \\
\hline & & 13CK024: Centre dyke \\
\hline & 13WJA_C005 & NO SAMPLES \\
\hline \multirow[t]{5}{*}{ 17-Jul-13 } & 13WJA_C006 & NO SAMPLES \\
\hline & 13WJA_C007 & 13WJA_C007A1 \\
\hline & 13WJA_C008 & SAMPLE INFO PENDING \\
\hline & 13WJA_C009 & 13WJA_C009A \\
\hline & 13WJA_C010 & 13WJA_C010A \\
\hline \multirow[t]{13}{*}{ 19-Jul-13 } & 13WJA_C015 & 13WJA_C015A Chilled \\
\hline & & 13WJA_C015B1 Centre \\
\hline & & 13WJA_C015B2 Centre \\
\hline & & 13WJA_C015B3 Centre \\
\hline & 13WJA_C016 & 13WJA_C016A1 \\
\hline & & 13WJA_C016A2 \\
\hline & 13WJA_C017 & 13WJA_C017A1 \\
\hline & & 13WJA_C017A2 \\
\hline & & 13WJA_C017A3 \\
\hline & 13WJA_C018 & 13WJA_C018A1 "Not porphyritic" \\
\hline & & 13WJA_C018A2 "Not porphyritic" \\
\hline & & 13WJA_C018B1 "porphyritic" \\
\hline & & 13WJA_C018B2 "porphyritic" \\
\hline \multirow[t]{10}{*}{$20-J u l-13$} & 13WJA_C019 & 13WJA_C019A (Fire assay) \\
\hline & 13WJA_C021 & 13WJA_C021A1 Centre \\
\hline & & 13WJA_C021A2 Centre \\
\hline & & 13WJA_C021B1 Top \\
\hline & 13WJA_C022 & 13WJA_C022A1 "Skarn" \\
\hline & & 13WJA_C022A2 "Skarn" \\
\hline & & 13WJA_C022B1 Basal "glassy" \\
\hline & & 13WJA_C022B2 Basal glassy" \\
\hline & & 13WJA_C022C1 top \\
\hline & & 13WJA_C022C2 top \\
\hline
\end{tabular}




\section{Appendix 2: Major and trace elements Detection limits}

LLOD = Lower limit of detection. Information from ALS Laboratories 2016 Schedule of Services (www.alsglobal.com)

\begin{tabular}{|c|c|c|c|}
\hline Major Element & $\begin{array}{l}\text { LLOD } \\
(w t \%)\end{array}$ & $\begin{array}{l}\text { Trace element } \\
\text { (continued) }\end{array}$ & $\begin{array}{r}\text { LLOD } \\
\text { (ppm) }\end{array}$ \\
\hline $\mathrm{SiO} 2$ & 0.01 & $\mathrm{La}$ & 0.5 \\
\hline TiO2 & 0.01 & $\mathrm{Ce}$ & 0.5 \\
\hline $\mathrm{Al} 2 \mathrm{O} 3$ & 0.01 & $\operatorname{Pr}$ & 0.03 \\
\hline $\mathrm{Fe} 2 \mathrm{O}^{*} *$ & 0.01 & $\mathrm{Nd}$ & 0.1 \\
\hline $\mathrm{MnO}$ & 0.01 & $\mathrm{Sm}$ & 0.03 \\
\hline $\mathrm{MgO}$ & 0.01 & $\mathrm{Eu}$ & 0.03 \\
\hline $\mathrm{CaO}$ & 0.01 & $\mathrm{Gd}$ & 0.05 \\
\hline $\mathrm{Na} 2 \mathrm{O}$ & 0.01 & $\mathrm{~Tb}$ & 0.01 \\
\hline $\mathrm{K} 2 \mathrm{O}$ & 0.01 & Dy & 0.05 \\
\hline $\mathrm{P} 2 \mathrm{O} 5$ & 0.01 & Ho & 0.01 \\
\hline \multirow[t]{2}{*}{ LOI } & 0.01 & Er & 0.03 \\
\hline & & $\mathrm{Tm}$ & 0.01 \\
\hline Trace element & $\begin{array}{l}\text { LLOD } \\
\text { (ppm) }\end{array}$ & $\mathrm{Yb}$ & 0.03 \\
\hline V & 5 & $\mathrm{Lu}$ & 0.01 \\
\hline $\mathrm{Cr}$ & 10 & $\mathrm{Rb}$ & 0.2 \\
\hline Co & 1 & $\mathrm{Sr}$ & 0.1 \\
\hline $\mathrm{Ni}$ & 1 & $\mathrm{Nb}$ & 0.2 \\
\hline $\mathrm{Zn}$ & 2 & Cs & 0.01 \\
\hline $\mathrm{Rb}$ & 0.2 & $\mathrm{Hf}$ & 0.2 \\
\hline $\mathrm{Sr}$ & 0.1 & Ta & 0.1 \\
\hline Y & 0.5 & Th & 0.05 \\
\hline $\mathrm{Zr}$ & 2 & $\mathrm{U}$ & 0.05 \\
\hline $\mathrm{Nb}$ & 0.2 & Y & 0.5 \\
\hline \multirow[t]{3}{*}{$\mathrm{Ba}$} & 0.5 & $\mathrm{Zr}$ & 2 \\
\hline & & $\mathrm{Sc}$ & 1 \\
\hline & & $\mathrm{Pb}$ & 2 \\
\hline
\end{tabular}




\section{Major and trace element data (start next page)}

Notes:

1. The foregoing table is a modified version of the first supplementary table in (Kingsbury et al., 2016) which is a paper that also serves as Chapter 3 in this thesis. The modification relates to showing the correct significant figures - refer to the preface for more information.

2. $\mathrm{Mg} \#=$ atomic $\mathrm{MgO} /\left(\mathrm{MgO}+\mathrm{Fe}_{2} \mathrm{O}_{3}\right)$ assuming $\mathrm{Fe}_{2} \mathrm{O}_{3}$ constitutes $85 \%$ of total $\mathrm{Fe}$.

3. Cells with dash $=$ concentration lower than lower limit of detection (see previous page). 


\begin{tabular}{|c|c|c|c|c|c|c|c|}
\hline Sample & 13_CK_001 & 13_CK_002 & 13_CK_003 & 13_CK_016 & 13_CK_004 & 13_CK_005 & 13_CK_006 \\
\hline Suite & S. Fiord & S. Fiord & S. Fiord & S. Fiord & S. Fiord & S. Fiord & S. Fiord \\
\hline $\mathrm{SiO} 2(\mathrm{wt} \%)$ & 50.6 & 50.5 & 47.3 & 50.0 & 47.8 & 47.3 & 49.3 \\
\hline TiO2 & 2.67 & 2.68 & 2.44 & 3.06 & 2.45 & 2.55 & 2.13 \\
\hline $\mathrm{A} 12 \mathrm{O} 3$ & 13.05 & 13.00 & 11.55 & 12.10 & 12.05 & 12.35 & 13.40 \\
\hline $\mathrm{Fe} 2 \mathrm{O} 3 \mathrm{t}$ & 15.96 & 16.24 & 13.63 & 16.74 & 15.29 & 13.79 & 15.63 \\
\hline $\mathrm{MnO}$ & 0.21 & 0.21 & 0.16 & 0.22 & 0.13 & 0.14 & 0.20 \\
\hline $\mathrm{MgO}$ & 4.31 & 4.39 & 3.55 & 4.22 & 3.68 & 3.54 & 4.83 \\
\hline $\mathrm{CaO}$ & 8.17 & 8.24 & 10.15 & 7.46 & 8.76 & 9.68 & 7.62 \\
\hline $\mathrm{Na} 2 \mathrm{O}$ & 3.36 & 3.32 & 2.37 & 2.94 & 2.75 & 2.59 & 3.65 \\
\hline $\mathrm{K} 2 \mathrm{O}$ & 1.44 & 1.42 & 0.51 & 1.41 & 0.47 & 0.49 & 2.04 \\
\hline $\mathrm{P} 2 \mathrm{O} 5$ & 0.32 & 0.33 & 0.28 & 0.36 & 0.32 & 0.30 & 0.26 \\
\hline LOI & 1.72 & 1.87 & 7.90 & 1.14 & 5.88 & 7.21 & 1.53 \\
\hline Total & 100.09 & 100.33 & 91.94 & 98.51 & 98.08 & 98.59 & 99.09 \\
\hline **Mg\# & 0.39 & 0.39 & 0.38 & 0.37 & 0.36 & 0.37 & 0.42 \\
\hline $\mathrm{V}(\mathrm{ppm})$ & 413.00 & 417.00 & 433.00 & 425.00 & 398.00 & 413.00 & 406.00 \\
\hline $\mathrm{Cr}$ & 50 & 30 & 30 & 40 & 30 & 30 & 60 \\
\hline Co & 37.00 & 37.00 & 12.00 & 39.00 & 24.00 & 40.00 & 34.00 \\
\hline $\mathrm{Ni}$ & 24 & 25 & 25 & 23 & 29 & 34 & 45 \\
\hline $\mathrm{Zn}$ & 144.00 & 145.00 & 43.00 & 137.00 & 52.00 & 40.00 & 74.00 \\
\hline $\mathrm{Nb}$ & 28.7 & 28.2 & 18.2 & 29.1 & 19.3 & 18.3 & 18.0 \\
\hline $\mathrm{Ba}$ & 293.00 & 286.00 & 101.00 & 332.00 & 97.90 & 98.20 & 252.00 \\
\hline $\mathrm{La}$ & 27.80 & 27.60 & 19.80 & 31.70 & 22.20 & 20.80 & 21.90 \\
\hline $\mathrm{Ce}$ & 59.2 & 58.1 & 46.8 & 69.4 & 51.6 & 48.9 & 50.3 \\
\hline $\operatorname{Pr}$ & 7.41 & 7.24 & 6.34 & 8.85 & 7.06 & 6.53 & 6.77 \\
\hline $\mathrm{Nd}$ & 30.60 & 30.20 & 28.00 & 36.80 & 30.90 & 29.80 & 29.60 \\
\hline $\mathrm{Sm}$ & 7.85 & 7.34 & 7.32 & 9.19 & 7.45 & 7.30 & 7.22 \\
\hline $\mathrm{Eu}$ & 2.19 & 2.13 & 2.26 & 2.39 & 2.32 & 2.16 & 2.17 \\
\hline Gd & 7.72 & 7.46 & 8.24 & 9.49 & 8.71 & 8.02 & 8.25 \\
\hline $\mathrm{Tb}$ & 1.23 & 1.25 & 1.34 & 1.52 & 1.39 & 1.32 & 1.30 \\
\hline Dy & 8.00 & 7.92 & 8.61 & 9.76 & 8.08 & 7.58 & 7.72 \\
\hline Ho & 1.57 & 1.54 & 1.69 & 1.89 & 1.77 & 1.61 & 1.72 \\
\hline $\mathrm{Er}$ & 4.53 & 4.44 & 4.64 & 5.16 & 4.66 & 4.58 & 4.59 \\
\hline $\mathrm{Tm}$ & 0.64 & 0.61 & 0.65 & 0.77 & 0.67 & 0.64 & 0.64 \\
\hline $\mathrm{Yb}$ & 4.13 & 3.90 & 4.22 & 4.49 & 4.23 & 3.96 & 4.29 \\
\hline $\mathrm{Lu}$ & 0.61 & 0.58 & 0.62 & 0.71 & 0.64 & 0.61 & 0.63 \\
\hline $\mathrm{Rb}$ & 46.0 & 45.7 & 18.0 & 52.6 & 17.0 & 16.6 & 58.3 \\
\hline $\mathrm{Sr}$ & 272 & 270 & 253 & 235 & 230 & 226 & 359 \\
\hline Cs & 1.63 & 1.63 & 0.84 & 1.60 & 0.74 & 0.67 & 0.91 \\
\hline $\mathrm{Hf}$ & 6.1 & 5.9 & 5.6 & 6.8 & 6.1 & 6.2 & 5.9 \\
\hline Тa & 1.6 & 1.5 & 1.0 & 1.6 & 1.2 & 1.1 & 1.1 \\
\hline Th & 5.34 & 5.08 & 3.07 & 6.46 & 3.67 & 3.44 & 3.95 \\
\hline $\mathrm{U}$ & 1.28 & 1.22 & 0.85 & 1.50 & 0.70 & 0.71 & 0.71 \\
\hline Y & 40.7 & 40.5 & 43.4 & 49.7 & 44.6 & 41.2 & 42.7 \\
\hline $\mathrm{Zr}$ & 211 & 208 & 197 & 249 & 231 & 225 & 221 \\
\hline $\mathrm{Sc}$ & 29 & 29 & 33 & 30 & 34 & 35 & 38 \\
\hline $\mathrm{Pb}$ & 18 & 23 & 15 & 14 & - & - & - \\
\hline
\end{tabular}




\begin{tabular}{|c|c|c|c|c|c|c|c|}
\hline $\begin{array}{l}\text { Sample } \\
\text { Suite } \\
\end{array}$ & $\begin{array}{r}\text { 13_CK_007 } \\
\text { S. Fiord } \\
\end{array}$ & $\begin{array}{r}13 \_C K \_008 \\
\text { S. Fiord } \\
\end{array}$ & $\begin{array}{r}\text { 13_CK_010 } \\
\text { S. Fiord } \\
\end{array}$ & $\begin{array}{r}\text { 13_CK_011 } \\
\text { S. Fiord } \\
\end{array}$ & $\begin{array}{r}\text { 13_CK_012 } \\
\text { S. Fiord } \\
\end{array}$ & $\begin{array}{r}13 \_C K \_015 \\
\text { S. Fiord } \\
\end{array}$ & $\begin{array}{r}\text { 13_CK_018 } \\
\text { S. Fiord } \\
\end{array}$ \\
\hline $\mathrm{SiO} 2(\mathrm{wt} \%)$ & 47.9 & 46.7 & 50.2 & 50.9 & 50.3 & 51.0 & 49.7 \\
\hline $\mathrm{TiO} 2$ & 2.27 & 3.11 & 3.09 & 3.11 & 3.06 & 3.09 & 2.69 \\
\hline $\mathrm{A} 12 \mathrm{O} 3$ & 12.10 & 12.55 & 12.55 & 12.75 & 12.65 & 12.60 & 12.75 \\
\hline $\mathrm{Fe} 2 \mathrm{O} 3 \mathrm{t}$ & 15.63 & 19.97 & 17.19 & 17.35 & 17.24 & 17.91 & 18.08 \\
\hline $\mathrm{MnO}$ & 0.21 & 0.19 & 0.22 & 0.21 & 0.20 & 0.22 & 0.22 \\
\hline $\mathrm{MgO}$ & 4.85 & 4.90 & 3.85 & 3.83 & 3.72 & 4.23 & 4.55 \\
\hline $\mathrm{CaO}$ & 9.06 & 8.44 & 7.37 & 7.64 & 7.18 & 7.59 & 7.91 \\
\hline $\mathrm{Na} 2 \mathrm{O}$ & 3.76 & 4.54 & 2.80 & 2.74 & 2.75 & 2.93 & 3.02 \\
\hline $\mathrm{K} 2 \mathrm{O}$ & 1.03 & 0.06 & 1.53 & 1.60 & 1.62 & 1.70 & 1.47 \\
\hline $\mathrm{P} 2 \mathrm{O} 5$ & 0.27 & 0.24 & 0.38 & 0.38 & 0.39 & 0.37 & 0.30 \\
\hline LOI & 3.78 & 2.31 & 1.56 & 1.21 & 1.57 & 1.02 & 1.45 \\
\hline Total & 99.34 & 101.00 & 99.06 & 100.04 & 99.01 & 100.92 & 100.37 \\
\hline ** Mg\# & 0.42 & 0.36 & 0.34 & 0.34 & 0.33 & 0.35 & 0.37 \\
\hline $\mathrm{V}(\mathrm{ppm})$ & 405.00 & 616.00 & 409.00 & 414.00 & 398.00 & 414.00 & 524.00 \\
\hline $\mathrm{Cr}$ & 20 & 30 & 30 & 30 & 20 & 30 & 30 \\
\hline Co & 25.00 & 48.00 & 40.00 & 42.00 & 39.00 & 42.00 & 43.00 \\
\hline $\mathrm{Ni}$ & 34 & 33 & 24 & 22 & 22 & 28 & 34 \\
\hline $\mathrm{Zn}$ & 60.00 & 34.00 & 135.00 & 150.00 & 138.00 & 145.00 & 101.00 \\
\hline $\mathrm{Nb}$ & 20.3 & 20.7 & 29.1 & 29.5 & 28.9 & 28.9 & 28.5 \\
\hline $\mathrm{Ba}$ & 145.00 & 10.50 & 302.00 & 310.00 & 307.00 & 340.00 & 269.00 \\
\hline $\mathrm{La}$ & 23.60 & 20.00 & 34.80 & 35.00 & 34.40 & 33.70 & 28.90 \\
\hline $\mathrm{Ce}$ & 54.4 & 48.0 & 76.3 & 77.1 & 75.4 & 74.3 & 62.0 \\
\hline $\operatorname{Pr}$ & 7.38 & 6.48 & 9.79 & 9.81 & 9.49 & 9.47 & 7.87 \\
\hline $\mathrm{Nd}$ & 33.00 & 27.40 & 40.30 & 41.30 & 39.80 & 39.90 & 32.00 \\
\hline $\mathrm{Sm}$ & 8.32 & 6.69 & 9.21 & 8.91 & 8.95 & 9.15 & 7.18 \\
\hline $\mathrm{Eu}$ & 2.38 & 2.07 & 2.33 & 2.35 & 2.35 & 2.37 & 2.08 \\
\hline Gd & 9.04 & 7.23 & 9.62 & 9.79 & 9.14 & 9.31 & 7.61 \\
\hline $\mathrm{Tb}$ & 1.48 & 1.15 & 1.54 & 1.57 & 1.49 & 1.52 & 1.25 \\
\hline Dy & 8.51 & 6.62 & 8.74 & 8.90 & 8.38 & 8.95 & 7.34 \\
\hline Но & 1.84 & 1.38 & 1.93 & 1.91 & 1.87 & 1.90 & 1.56 \\
\hline $\mathrm{Er}$ & 5.30 & 3.87 & 5.17 & 5.40 & 5.02 & 5.13 & 4.16 \\
\hline $\mathrm{Tm}$ & 0.74 & 0.51 & 0.69 & 0.74 & 0.68 & 0.71 & 0.60 \\
\hline $\mathrm{Yb}$ & 4.48 & 3.34 & 4.51 & 4.77 & 4.55 & 4.60 & 3.86 \\
\hline $\mathrm{Lu}$ & 0.71 & 0.53 & 0.75 & 0.76 & 0.74 & 0.71 & 0.57 \\
\hline $\mathrm{Rb}$ & 32.9 & 0.6 & 57.1 & 58.7 & 57.2 & 58.1 & 48.0 \\
\hline $\mathrm{Sr}$ & 296 & 59 & 211 & 212 & 208 & 230 & 263 \\
\hline Cs & 0.75 & 0.39 & 1.75 & 1.77 & 1.54 & 1.75 & 0.95 \\
\hline $\mathrm{Hf}$ & 6.0 & 5.5 & 7.4 & 7.6 & 7.3 & 7.2 & 5.9 \\
\hline $\mathrm{Ta}$ & 1.2 & 1.2 & 1.8 & 1.8 & 1.8 & 1.8 & 1.8 \\
\hline Th & 3.59 & 3.39 & 7.52 & 7.83 & 7.59 & 7.55 & 5.84 \\
\hline $\mathrm{U}$ & 0.69 & 0.61 & 1.31 & 1.35 & 1.34 & 1.41 & 1.11 \\
\hline Y & 48.3 & 36.0 & 48.2 & 49.3 & 46.7 & 48.6 & 40.5 \\
\hline $\mathrm{Zr}$ & 227 & 197 & 277 & 289 & 279 & 281 & 226 \\
\hline $\mathrm{Sc}$ & 31 & 35 & 31 & 32 & 31 & 33 & 31 \\
\hline $\mathrm{Pb}$ & 2 & - & 7 & 2 & - & 3 & - \\
\hline
\end{tabular}




\begin{tabular}{|c|c|c|c|c|c|c|c|}
\hline Sample & 13_CK_019 & 13_CK_021 & 13_CK_023 & $\begin{array}{l}\text { 13-WJA- } \\
\text { C004_A }\end{array}$ & $\begin{array}{l}\text { 13-WJA- } \\
\text { C007_A1 }\end{array}$ & $\begin{array}{r}\text { 13-WJA- } \\
\text { C008_A1 }\end{array}$ & $\begin{array}{l}\text { 13-WJA- } \\
\text { C008_A2 }\end{array}$ \\
\hline Suite & S. Fiord & S. Fiord & S. Fiord & S. Fiord & S. Fiord & S. Fiord & S. Fiord \\
\hline $\mathrm{SiO} 2(\mathrm{wt} \%)$ & 49.6 & 49.5 & 49.8 & 51.7 & 48.7 & 48.6 & 49.0 \\
\hline $\mathrm{TiO} 2$ & 2.64 & 2.63 & 1.66 & 3.18 & 3.02 & 2.55 & 2.58 \\
\hline $\mathrm{A} 12 \mathrm{O} 3$ & 12.75 & 12.70 & 13.95 & 12.55 & 12.40 & 12.20 & 12.30 \\
\hline $\mathrm{Fe} 2 \mathrm{O} 3 \mathrm{t}$ & 19.30 & 19.02 & 13.01 & 16.20 & 16.15 & 16.45 & 16.75 \\
\hline $\mathrm{MnO}$ & 0.23 & 0.22 & 0.16 & 0.22 & 0.23 & 0.24 & 0.24 \\
\hline $\mathrm{MgO}$ & 4.96 & 4.97 & 6.06 & 4.03 & 4.78 & 4.81 & 4.81 \\
\hline $\mathrm{CaO}$ & 8.63 & 8.12 & 7.80 & 7.52 & 7.70 & 8.92 & 8.98 \\
\hline $\mathrm{Na} 2 \mathrm{O}$ & 3.24 & 3.12 & 4.15 & 2.97 & 2.79 & 2.61 & 2.65 \\
\hline $\mathrm{K} 2 \mathrm{O}$ & 0.82 & 1.05 & 0.78 & 1.68 & 1.28 & 0.70 & 0.65 \\
\hline $\mathrm{P} 2 \mathrm{O} 5$ & 0.27 & 0.27 & 0.17 & 0.38 & 0.39 & 0.26 & 0.27 \\
\hline LOI & 1.16 & 1.28 & 2.14 & 1.00 & 1.29 & 1.06 & 0.90 \\
\hline Total & 101.72 & 101.03 & 98.44 & 101.49 & 98.80 & 98.44 & 99.18 \\
\hline$* * \mathrm{Mg} \#$ & 0.37 & 0.38 & 0.52 & 0.37 & 0.41 & 0.41 & 0.40 \\
\hline $\mathrm{V}(\mathrm{ppm})$ & 476.00 & 465.00 & 312.00 & 417.00 & 458.00 & 477.00 & 483.00 \\
\hline $\mathrm{Cr}$ & 50 & 50 & 150 & 30 & 70 & 60 & 50 \\
\hline Co & 47.00 & 48.00 & 42.00 & 42.00 & 43.00 & 50.00 & 49.00 \\
\hline $\mathrm{Ni}$ & 39 & 39 & 76 & 21 & 40 & 39 & 40 \\
\hline $\mathrm{Zn}$ & 145 & 121 & 66 & 147 & 163 & 150 & 149 \\
\hline $\mathrm{Nb}$ & 17.8 & 17.4 & 7.7 & 27.0 & 24.0 & 16.6 & 16.9 \\
\hline $\mathrm{Ba}$ & 190.00 & 186.50 & 137.00 & 301.00 & 239.00 & 131.00 & 131.50 \\
\hline $\mathrm{La}$ & 18.70 & 18.10 & 13.10 & 31.50 & 25.40 & 17.10 & 17.50 \\
\hline $\mathrm{Ce}$ & 43.8 & 42.7 & 30.4 & 67.2 & 56.6 & 38.7 & 39.8 \\
\hline $\operatorname{Pr}$ & 6.02 & 5.86 & 4.24 & 8.64 & 7.52 & 5.26 & 5.45 \\
\hline $\mathrm{Nd}$ & 26.80 & 26.00 & 19.20 & 36.80 & 33.40 & 24.90 & 25.00 \\
\hline $\mathrm{Sm}$ & 6.90 & 6.46 & 5.27 & 8.43 & 8.95 & 6.43 & 7.00 \\
\hline $\mathrm{Eu}$ & 2.18 & 2.15 & 1.44 & 2.33 & 2.47 & 2.04 & 2.24 \\
\hline $\mathrm{Gd}$ & 7.79 & 7.51 & 5.90 & 9.62 & 10.10 & 7.92 & 8.18 \\
\hline $\mathrm{Tb}$ & 1.28 & 1.21 & 0.91 & 1.49 & 1.66 & 1.28 & 1.32 \\
\hline Dy & 7.52 & 7.40 & 5.46 & 9.17 & 9.47 & 7.57 & 7.64 \\
\hline Ho & 1.68 & 1.57 & 1.12 & 1.81 & 1.92 & 1.54 & 1.60 \\
\hline $\mathrm{Er}$ & 4.47 & 4.16 & 3.07 & 5.16 & 5.61 & 3.87 & 4.45 \\
\hline $\mathrm{Tm}$ & 0.58 & 0.58 & 0.47 & 0.76 & 0.79 & 0.61 & 0.62 \\
\hline $\mathrm{Yb}$ & 3.93 & 3.75 & 2.67 & 4.92 & 5.34 & 3.96 & 4.40 \\
\hline $\mathrm{Lu}$ & 0.62 & 0.59 & 0.36 & 0.66 & 0.81 & 0.56 & 0.60 \\
\hline $\mathrm{Rb}$ & 25.1 & 31.5 & 28.4 & 61.1 & 45.8 & 21.2 & 21.0 \\
\hline $\mathrm{Sr}$ & 292 & 319 & 251 & 218 & 218 & 208 & 216 \\
\hline Cs & 0.89 & 0.83 & 2.19 & 1.54 & 1.07 & 0.65 & 0.75 \\
\hline $\mathrm{Hf}$ & 5.2 & 5.1 & 4.3 & 7.2 & 7.4 & 4.9 & 4.9 \\
\hline $\mathrm{Ta}$ & 1.1 & 1.1 & 0.5 & 1.7 & 1.6 & 1.0 & 1.1 \\
\hline Th & 2.76 & 2.70 & 2.69 & 6.50 & 3.90 & 2.22 & 2.24 \\
\hline $\mathrm{U}$ & 0.53 & 0.47 & 0.58 & 1.53 & 0.97 & 0.61 & 0.66 \\
\hline $\mathrm{Y}$ & 41.5 & 40.1 & 28.1 & 46.9 & 50.9 & 39.5 & 40.7 \\
\hline $\mathrm{Zr}$ & 195 & 188 & 147 & 262 & 263 & 177 & 183 \\
\hline $\mathrm{Sc}$ & 36.0 & 36.0 & 32.0 & 34.0 & 39.0 & 40.0 & 38.0 \\
\hline $\mathrm{Pb}$ & 3 & - & - & 7 & 4 & 2 & 3 \\
\hline
\end{tabular}




\begin{tabular}{|c|c|c|c|c|c|c|c|}
\hline Sample & $\begin{array}{l}\text { 13-WJA- } \\
\text { C009_A }\end{array}$ & $\begin{array}{l}\text { 13-WJA- } \\
\text { C010_A }\end{array}$ & $\begin{array}{l}\text { 13-WJA- } \\
\text { C015_A }\end{array}$ & $\begin{array}{l}\text { 13-WJA- } \\
\text { C015_B1 }\end{array}$ & $\begin{array}{l}\text { 13-WJA- } \\
\text { C015_B2 }\end{array}$ & $\begin{array}{l}\text { 13-WJA- } \\
\text { C015_B3 }\end{array}$ & $\begin{array}{l}\text { 13-WJA- } \\
\text { C017_A1 }\end{array}$ \\
\hline Suite & S. Fiord & S. Fiord & S. Fiord & S. Fiord & S. Fiord & S. Fiord & S. Fiord \\
\hline $\mathrm{SiO} 2(\mathrm{wt} \%)$ & 51.5 & 51.3 & 50.1 & 50.3 & 49.8 & 50.3 & 54.8 \\
\hline $\mathrm{TiO} 2$ & 3.01 & 2.51 & 3.14 & 3.30 & 3.45 & 3.45 & 2.29 \\
\hline $\mathrm{Al} 2 \mathrm{O} 3$ & 12.65 & 13.25 & 12.70 & 12.35 & 12.20 & 11.95 & 11.90 \\
\hline $\mathrm{Fe} 2 \mathrm{O} 3 \mathrm{t}$ & 15.85 & 15.65 & 16.80 & 16.60 & 16.80 & 16.55 & 13.40 \\
\hline $\mathrm{MnO}$ & 0.22 & 0.22 & 0.22 & 0.22 & 0.22 & 0.22 & 0.19 \\
\hline $\mathrm{MgO}$ & 4.05 & 4.46 & 4.75 & 3.61 & 3.66 & 3.37 & 4.10 \\
\hline $\mathrm{CaO}$ & 7.44 & 6.26 & 7.48 & 6.73 & 6.69 & 6.90 & 7.63 \\
\hline $\mathrm{Na} 2 \mathrm{O}$ & 2.98 & 3.48 & 3.35 & 4.03 & 3.93 & 3.87 & 2.19 \\
\hline $\mathrm{K} 2 \mathrm{O}$ & 1.69 & 2.00 & 0.98 & 0.71 & 0.71 & 0.79 & 0.73 \\
\hline $\mathrm{P} 2 \mathrm{O} 5$ & 0.39 & 0.33 & 0.36 & 0.42 & 0.41 & 0.41 & 0.29 \\
\hline LOI & 1.04 & 1.30 & 1.22 & 1.69 & 1.67 & 1.74 & 3.03 \\
\hline Total & 100.89 & 100.82 & 101.15 & 100.01 & 99.59 & 99.60 & 100.60 \\
\hline$* * \mathrm{Mg} \#$ & 0.37 & 0.40 & 0.40 & 0.34 & 0.34 & 0.32 & 0.42 \\
\hline $\mathrm{V}(\mathrm{ppm})$ & 418.00 & 420.00 & 496.00 & 358.00 & 405.00 & 277.00 & 405.00 \\
\hline $\mathrm{Cr}$ & 40 & 30 & 40 & 10 & 10 & & 40 \\
\hline Co & 43.00 & 45.00 & 45.00 & 39.00 & 39.00 & 37.00 & 38.00 \\
\hline $\mathrm{Ni}$ & 26 & 33 & 36 & 14 & 12 & 8 & 37 \\
\hline $\mathrm{Zn}$ & 159 & 119 & 89 & 94 & 99 & 95 & 125 \\
\hline $\mathrm{Nb}$ & 27.5 & 27.5 & 21.9 & 28.1 & 27.3 & 29.7 & 18.4 \\
\hline $\mathrm{Ba}$ & 354.00 & 297.00 & 138.50 & 177.50 & 166.50 & 168.00 & 185.00 \\
\hline $\mathrm{La}$ & 32.80 & 28.60 & 22.00 & 28.20 & 26.20 & 28.80 & 20.80 \\
\hline $\mathrm{Ce}$ & 69.0 & 59.5 & 49.4 & 62.1 & 58.9 & 64.4 & 46.6 \\
\hline $\operatorname{Pr}$ & 8.90 & 7.66 & 6.78 & 8.60 & 8.26 & 8.73 & 6.49 \\
\hline $\mathrm{Nd}$ & 37.70 & 31.40 & 31.40 & 37.60 & 35.60 & 38.70 & 29.10 \\
\hline $\mathrm{Sm}$ & 8.79 & 7.99 & 8.31 & 9.81 & 9.04 & 9.78 & 7.18 \\
\hline $\mathrm{Eu}$ & 2.53 & 2.26 & 2.52 & 2.81 & 2.78 & 2.89 & 2.17 \\
\hline $\mathrm{Gd}$ & 9.97 & 8.89 & 9.91 & 10.50 & 11.15 & 11.35 & 8.12 \\
\hline $\mathrm{Tb}$ & 1.47 & 1.25 & 1.60 & 1.72 & 1.76 & 1.82 & 1.29 \\
\hline Dy & 9.45 & 8.16 & 9.42 & 11.05 & 10.35 & 10.80 & 8.20 \\
\hline Ho & 2.02 & 1.64 & 2.00 & 2.22 & 2.16 & 2.43 & 1.61 \\
\hline $\mathrm{Er}$ & 5.49 & 4.33 & 5.49 & 6.01 & 5.86 & 6.27 & 4.48 \\
\hline $\mathrm{Tm}$ & 0.76 & 0.59 & 0.71 & 0.85 & 0.87 & 0.97 & 0.60 \\
\hline $\mathrm{Yb}$ & 4.90 & 4.36 & 4.93 & 5.43 & 5.57 & 5.79 & 4.07 \\
\hline $\mathrm{Lu}$ & 0.77 & 0.64 & 0.66 & 0.78 & 0.78 & 0.93 & 0.62 \\
\hline $\mathrm{Rb}$ & 61.7 & 68.6 & 33.1 & 24.0 & 23.6 & 23.3 & 14.5 \\
\hline $\mathrm{Sr}$ & 261 & 273 & 199 & 235 & 234 & 194 & 210 \\
\hline Cs & 1.52 & 1.45 & 0.86 & 0.46 & 0.40 & 0.36 & 0.35 \\
\hline $\mathrm{Hf}$ & 7.6 & 6.3 & 6.6 & 8.6 & 8.1 & 8.4 & 6.2 \\
\hline $\mathrm{Ta}$ & 1.8 & 1.7 & 1.4 & 1.7 & 1.8 & 1.9 & 1.2 \\
\hline Th & 6.37 & 5.02 & 3.04 & 3.65 & 3.59 & 3.90 & 3.37 \\
\hline $\mathrm{U}$ & 1.46 & 1.38 & 0.80 & 0.94 & 1.03 & 1.08 & 1.01 \\
\hline $\mathrm{Y}$ & 48.6 & 41.5 & 47.9 & 55.3 & 54.9 & 57.7 & 41.1 \\
\hline $\mathrm{Zr}$ & 265 & 226 & 235 & 294 & 287 & 316 & 230 \\
\hline $\mathrm{Sc}$ & 34 & 32 & 36 & 31 & 32 & 30 & 33 \\
\hline $\mathrm{Pb}$ & 6 & 2 & - & 2 & - & 2 & 3 \\
\hline
\end{tabular}




\begin{tabular}{|c|c|c|c|c|c|c|c|}
\hline Sample & $\begin{array}{l}\text { 13-WJA- } \\
\text { C017_A2 }\end{array}$ & $\begin{array}{l}\text { 13-WJA- } \\
\text { C018_A1 }\end{array}$ & $\begin{array}{l}\text { 13-WJA- } \\
\text { C018_A2 }\end{array}$ & $\begin{array}{l}\text { 13-WJA- } \\
\text { C019_A1 }\end{array}$ & $\begin{array}{l}\text { 13-WJA- } \\
\text { C022_A2 }\end{array}$ & $\begin{array}{l}\text { 13-WJA- } \\
\text { C022_B2 }\end{array}$ & $\begin{array}{l}\text { 13-WJA- } \\
\text { C022_C1 }\end{array}$ \\
\hline Suite & S. Fiord & S. Fiord & S. Fiord & S. Fiord & Isachsen & Isachsen & Isachsen \\
\hline $\mathrm{SiO} 2(\mathrm{wt} \%)$ & 52.9 & 48.9 & 48.8 & 51.4 & 34.8 & 46.9 & 43.8 \\
\hline $\mathrm{TiO} 2$ & 2.31 & 1.93 & 1.97 & 3.24 & 2.63 & 1.67 & 1.65 \\
\hline $\mathrm{Al} 2 \mathrm{O} 3$ & 11.85 & 13.25 & 13.30 & 12.90 & 14.10 & 14.75 & 14.00 \\
\hline $\mathrm{Fe} 2 \mathrm{O} 3 \mathrm{t}$ & 13.85 & 11.00 & 12.75 & 16.30 & 23.10 & 10.85 & 10.15 \\
\hline $\mathrm{MnO}$ & 0.20 & 0.18 & 0.19 & 0.24 & 0.25 & 0.13 & 0.12 \\
\hline $\mathrm{MgO}$ & 4.21 & 3.98 & 4.05 & 4.10 & 3.78 & 3.47 & 2.86 \\
\hline $\mathrm{CaO}$ & 7.99 & 9.97 & 10.25 & 4.74 & 3.21 & 8.31 & 11.00 \\
\hline $\mathrm{Na} 2 \mathrm{O}$ & 2.19 & 3.16 & 3.22 & 3.79 & 4.62 & 3.56 & 3.12 \\
\hline $\mathrm{K} 2 \mathrm{O}$ & 0.59 & 0.29 & 0.28 & 1.73 & 0.11 & 0.12 & 0.13 \\
\hline $\mathrm{P} 2 \mathrm{O} 5$ & 0.29 & 0.18 & 0.20 & 0.40 & 0.35 & 0.21 & 0.21 \\
\hline LOI & 4.33 & 5.41 & 4.94 & 1.27 & 12.60 & 10.30 & 12.55 \\
\hline Total & 100.76 & 98.28 & 99.98 & 100.17 & 99.56 & 100.31 & 99.63 \\
\hline$* * \mathrm{Mg} \#$ & 0.41 & 0.46 & 0.43 & 0.37 & 0.28 & 0.43 & 0.40 \\
\hline $\mathrm{V}(\mathrm{ppm})$ & 412.00 & 450.00 & 470.00 & 442.00 & 440.00 & 295.00 & 294.00 \\
\hline $\mathrm{Cr}$ & 30 & 30 & 30 & 30 & 40 & 100 & 100 \\
\hline Co & 39.00 & 41.00 & 43.00 & 38.00 & 50.00 & 34.00 & 34.00 \\
\hline $\mathrm{Ni}$ & 34 & 46 & 48 & 22 & 50 & 58 & 85 \\
\hline $\mathrm{Zn}$ & 123 & 54 & 51 & 140 & 55 & 106 & 34 \\
\hline $\mathrm{Nb}$ & 18.3 & 13.1 & 13.5 & 28.8 & 27.8 & 7.5 & 7.7 \\
\hline $\mathrm{Ba}$ & 155.00 & 128.50 & 123.00 & 338.00 & 20.90 & 62.90 & 86.40 \\
\hline $\mathrm{La}$ & 21.40 & 16.30 & 16.70 & 32.90 & 23.20 & 12.80 & 13.10 \\
\hline $\mathrm{Ce}$ & 47.9 & 36.5 & 37.3 & 70.9 & 51.4 & 29.0 & 30.0 \\
\hline $\operatorname{Pr}$ & 6.69 & 5.01 & 5.22 & 9.18 & 6.86 & 4.04 & 4.41 \\
\hline $\mathrm{Nd}$ & 29.30 & 22.40 & 24.50 & 38.10 & 30.10 & 18.40 & 19.70 \\
\hline $\mathrm{Sm}$ & 7.29 & 5.89 & 6.55 & 9.51 & 8.08 & 4.66 & 5.06 \\
\hline $\mathrm{Eu}$ & 2.29 & 1.92 & 1.71 & 2.55 & 1.66 & 1.53 & 1.53 \\
\hline $\mathrm{Gd}$ & 8.03 & 7.04 & 7.14 & 10.65 & 7.66 & 5.47 & 5.36 \\
\hline $\mathrm{Tb}$ & 1.31 & 1.31 & 1.18 & 1.63 & 1.36 & 0.96 & 0.88 \\
\hline Dy & 8.08 & 8.00 & 7.79 & 9.74 & 8.02 & 5.20 & 5.22 \\
\hline Ho & 1.55 & 1.65 & 1.66 & 2.00 & 1.66 & 1.07 & 1.08 \\
\hline $\mathrm{Er}$ & 4.27 & 4.43 & 4.79 & 5.26 & 4.53 & 2.76 & 2.75 \\
\hline $\mathrm{Tm}$ & 0.62 & 0.65 & 0.68 & 0.79 & 0.66 & 0.38 & 0.38 \\
\hline $\mathrm{Yb}$ & 4.06 & 4.27 & 4.67 & 5.40 & 4.34 & 2.59 & 2.65 \\
\hline $\mathrm{Lu}$ & 0.62 & 0.66 & 0.65 & 0.75 & 0.60 & 0.41 & 0.31 \\
\hline $\mathrm{Rb}$ & 10.3 & 8.4 & 6.2 & 64.0 & 1.6 & 1.2 & 1.5 \\
\hline $\mathrm{Sr}$ & 213.0 & 198.0 & 198.5 & 185.5 & 56.5 & 152.0 & 190.5 \\
\hline Cs & 0.24 & 0.20 & 0.15 & 1.58 & 0.14 & 0.08 & 0.08 \\
\hline $\mathrm{Hf}$ & 6.6 & 4.6 & 4.9 & 7.9 & 6.0 & 3.6 & 3.9 \\
\hline $\mathrm{Ta}$ & 1.1 & 0.8 & 0.9 & 1.8 & 1.6 & 0.5 & 0.5 \\
\hline Th & 3.30 & 2.70 & 2.66 & 6.80 & 5.07 & 2.72 & 2.71 \\
\hline $\mathrm{U}$ & 0.84 & 0.75 & 0.69 & 1.62 & 1.29 & 0.64 & 0.67 \\
\hline $\mathrm{Y}$ & 41.0 & 41.9 & 42.6 & 50.9 & 43.3 & 26.4 & 26.8 \\
\hline $\mathrm{Zr}$ & 226 & 162 & 165 & 277 & 230 & 132 & 136 \\
\hline $\mathrm{Sc}$ & 33 & 44 & 46 & 34 & 33 & 31 & 30 \\
\hline $\mathrm{Pb}$ & 5 & - & - & 2 & 6 & - & - \\
\hline
\end{tabular}




\begin{tabular}{|c|c|c|c|c|c|c|c|}
\hline Sample & $\begin{array}{l}\text { 13-WJA- } \\
\text { C022_C2 }\end{array}$ & $\begin{array}{l}\text { 13-WJA- } \\
\text { C024_A1 }\end{array}$ & $\begin{array}{l}\text { 13-WJA- } \\
\text { C027_A2 }\end{array}$ & $\begin{array}{l}\text { 13-WJA- } \\
\text { C028_A2 }\end{array}$ & $\begin{array}{r}\text { 13-WJA- } \\
\text { C029_A }\end{array}$ & $\begin{array}{l}\text { 13-WJA- } \\
\text { C032_A }\end{array}$ & AX85-241 \\
\hline Suite & Isachsen & S. Fiord & S. Fiord & S. Fiord & S. Fiord & S. Fiord & Isachsen \\
\hline $\mathrm{SiO} 2(\mathrm{wt} \%)$ & 43.5 & 50.9 & 51.2 & 53.3 & 48.6 & 50.1 & 49.3 \\
\hline $\mathrm{TiO} 2$ & 1.57 & 2.98 & 2.23 & 2.62 & 2.88 & 3.13 & 3.07 \\
\hline $\mathrm{A} 12 \mathrm{O} 3$ & 13.70 & 12.85 & 14.80 & 11.60 & 12.85 & 12.45 & 12.30 \\
\hline $\mathrm{Fe} 2 \mathrm{O} 3 \mathrm{t}$ & 9.46 & 15.65 & 14.35 & 18.35 & 16.70 & 16.95 & 13.85 \\
\hline $\mathrm{MnO}$ & 0.14 & 0.23 & 0.20 & 0.27 & 0.24 & 0.24 & 0.19 \\
\hline $\mathrm{MgO}$ & 2.69 & 4.24 & 4.44 & 1.98 & 4.92 & 4.78 & 3.84 \\
\hline $\mathrm{CaO}$ & 13.55 & 8.77 & 9.62 & 6.32 & 9.11 & 9.16 & 8.04 \\
\hline $\mathrm{Na} 2 \mathrm{O}$ & 2.13 & 2.53 & 2.67 & 3.17 & 2.86 & 2.54 & 2.44 \\
\hline $\mathrm{K} 2 \mathrm{O}$ & 0.16 & 1.11 & 0.41 & 2.14 & 1.23 & 0.97 & 0.60 \\
\hline $\mathrm{P} 2 \mathrm{O} 5$ & 0.20 & 0.37 & 0.22 & 0.71 & 0.35 & 0.41 & 0.63 \\
\hline LOI & 12.15 & 1.27 & 1.35 & 0.34 & -0.10 & 0.66 & 3.85 \\
\hline Total & 99.30 & 100.96 & 101.52 & 100.87 & 99.70 & 101.45 & 98.25 \\
\hline$* * \mathrm{Mg} \#$ & 0.40 & 0.39 & 0.42 & 0.20 & 0.41 & 0.40 & 0.39 \\
\hline $\mathrm{V}(\mathrm{ppm})$ & 282.00 & 419.00 & 413.00 & 82.00 & 421.00 & 450.00 & 300.00 \\
\hline $\mathrm{Cr}$ & 100 & 40 & 20 & & 30 & 60 & 40 \\
\hline Co & 36.00 & 40.00 & 39.00 & 34.00 & 47.00 & 46.00 & 38.00 \\
\hline $\mathrm{Ni}$ & 59 & 33 & 28 & 3 & 39 & 42 & 34 \\
\hline $\mathrm{Zn}$ & 58 & 145 & 119 & 219 & 144 & 152 & 217 \\
\hline $\mathrm{Nb}$ & 10.4 & 23.4 & 9.3 & 38.3 & 21.5 & 25.8 & 28.5 \\
\hline $\mathrm{Ba}$ & 92.30 & 268.00 & 110.00 & 425.00 & 247.00 & 227.00 & 904.00 \\
\hline $\mathrm{La}$ & 12.40 & 25.90 & 12.20 & 50.00 & 25.90 & 26.90 & 36.10 \\
\hline $\mathrm{Ce}$ & 28.5 & 57.2 & 28.7 & 108.5 & 56.6 & 60.4 & 84.1 \\
\hline $\operatorname{Pr}$ & 4.09 & 7.78 & 4.34 & 14.40 & 7.54 & 8.26 & 11.10 \\
\hline $\mathrm{Nd}$ & 17.60 & 33.20 & 19.90 & 60.90 & 33.10 & 36.60 & 49.10 \\
\hline $\mathrm{Sm}$ & 4.87 & 8.21 & 5.60 & 15.20 & 7.81 & 9.78 & 12.00 \\
\hline $\mathrm{Eu}$ & 1.60 & 2.51 & 1.71 & 3.87 & 2.31 & 2.61 & 3.32 \\
\hline $\mathrm{Gd}$ & 5.01 & 9.28 & 6.49 & 16.05 & 9.17 & 10.75 & 10.80 \\
\hline $\mathrm{Tb}$ & 0.84 & 1.56 & 1.05 & 2.39 & 1.41 & 1.72 & 1.66 \\
\hline Dy & 5.16 & 9.31 & 6.48 & 14.60 & 8.04 & 10.20 & 9.93 \\
\hline Ho & 1.03 & 1.85 & 1.35 & 2.90 & 1.62 & 2.21 & 1.95 \\
\hline $\mathrm{Er}$ & 2.91 & 4.82 & 3.38 & 7.84 & 4.38 & 5.56 & 5.38 \\
\hline $\mathrm{Tm}$ & 0.41 & 0.81 & 0.52 & 1.09 & 0.64 & 0.80 & 0.74 \\
\hline $\mathrm{Yb}$ & 2.65 & 4.74 & 3.21 & 7.36 & 4.27 & 5.91 & 4.47 \\
\hline $\mathrm{Lu}$ & 0.38 & 0.70 & 0.54 & 1.08 & 0.58 & 0.83 & 0.70 \\
\hline $\mathrm{Rb}$ & 1.3 & 37.7 & 15.6 & 78.7 & 38.4 & 35.5 & 15.9 \\
\hline $\mathrm{Sr}$ & 264.0 & 209.0 & 201.0 & 216.0 & 249.0 & 191.0 & 368.0 \\
\hline $\mathrm{Cs}$ & 0.03 & 0.89 & 0.89 & 2.64 & 1.11 & 0.89 & 5.11 \\
\hline $\mathrm{Hf}$ & 3.5 & 6.8 & 4.4 & 10.9 & 6.2 & 7.7 & 7.3 \\
\hline $\mathrm{Ta}$ & 0.6 & 1.4 & 0.6 & 2.3 & 1.4 & 1.6 & 1.8 \\
\hline Th & 2.50 & 4.18 & 1.78 & 8.13 & 4.30 & 4.15 & 4.89 \\
\hline $\mathrm{U}$ & 0.62 & 1.12 & 0.50 & 2.15 & 1.10 & 1.11 & 1.43 \\
\hline $\mathrm{Y}$ & 25.9 & 46.4 & 34.1 & 74.7 & 42.9 & 55.5 & 49.7 \\
\hline $\mathrm{Zr}$ & 121 & 242 & 144 & 405 & 222 & 280 & 277 \\
\hline $\mathrm{Sc}$ & 29 & 31 & 37 & 22 & 34 & 40 & 30 \\
\hline $\mathrm{Pb}$ & 2 & 2 & 4 & 13 & - & 3 & 3 \\
\hline
\end{tabular}




\begin{tabular}{|c|c|c|c|c|c|c|c|}
\hline $\begin{array}{l}\text { Sample } \\
\text { Suite } \\
\end{array}$ & $\begin{array}{r}\text { AX85-242 } \\
\text { Isachsen } \\
\end{array}$ & $\begin{array}{r}\text { AX85-243 } \\
\text { Isachsen } \\
\end{array}$ & $\begin{array}{r}\text { AX85-244 } \\
\text { Isachsen } \\
\end{array}$ & $\begin{array}{r}\text { AX85-245 } \\
\text { Isachsen } \\
\end{array}$ & $\begin{array}{r}\text { AX85-246 } \\
\text { Isachsen } \\
\end{array}$ & $\begin{array}{r}\text { AX85-247 } \\
\text { Isachsen } \\
\end{array}$ & $\begin{array}{r}\text { AX85-250 } \\
\text { Isachsen } \\
\end{array}$ \\
\hline $\mathrm{SiO} 2(\mathrm{wt} \%)$ & 51.9 & 45.2 & 35.5 & 48.1 & 49.2 & 47.3 & 47.2 \\
\hline $\mathrm{TiO} 2$ & 3.14 & 3.63 & 3.04 & 2.39 & 2.41 & 3.53 & 3.50 \\
\hline $\mathrm{Al} 2 \mathrm{O} 3$ & 12.60 & 14.65 & 16.80 & 12.85 & 12.95 & 11.20 & 11.50 \\
\hline $\mathrm{Fe} 2 \mathrm{O} 3 \mathrm{t}$ & 14.10 & 12.15 & 13.65 & 14.50 & 14.85 & 17.10 & 16.90 \\
\hline $\mathrm{MnO}$ & 0.21 & 0.22 & 0.25 & 0.21 & 0.21 & 0.24 & 0.24 \\
\hline $\mathrm{MgO}$ & 3.91 & 1.94 & 3.40 & 5.54 & 5.15 & 5.52 & 5.35 \\
\hline $\mathrm{CaO}$ & 8.28 & 4.92 & 6.75 & 10.25 & 9.96 & 8.46 & 8.93 \\
\hline $\mathrm{Na} 2 \mathrm{O}$ & 2.93 & 3.79 & 4.05 & 2.38 & 2.37 & 2.11 & 2.31 \\
\hline $\mathrm{K} 2 \mathrm{O}$ & 0.75 & 0.87 & 0.41 & 0.29 & 0.57 & 0.82 & 0.85 \\
\hline $\mathrm{P} 2 \mathrm{O} 5$ & 0.64 & 1.02 & 0.35 & 0.22 & 0.24 & 0.38 & 0.38 \\
\hline LOI & 1.79 & 9.55 & 13.85 & 1.98 & 1.34 & 1.28 & 0.82 \\
\hline Total & 100.43 & 98.02 & 98.09 & 98.79 & 99.31 & 98.02 & 98.04 \\
\hline$* * \mathrm{Mg} \#$ & 0.39 & 0.27 & 0.37 & 0.47 & 0.45 & 0.43 & 0.42 \\
\hline $\mathrm{V}(\mathrm{ppm})$ & 303.00 & 323.00 & 522.00 & 415.00 & 423.00 & 540.00 & 519.00 \\
\hline $\mathrm{Cr}$ & 40 & 50 & 120 & 90 & 80 & 130 & 130 \\
\hline Co & 35.00 & 145.00 & 63.00 & 46.00 & 46.00 & 48.00 & 45.00 \\
\hline $\mathrm{Ni}$ & 31 & 71 & 76 & 55 & 55 & 80 & 70 \\
\hline $\mathrm{Zn}$ & 155 & 99 & 23 & 121 & 121 & 156 & 147 \\
\hline $\mathrm{Nb}$ & 28.4 & 32.0 & 11.9 & 8.9 & 9.1 & 23.6 & 23.0 \\
\hline $\mathrm{Ba}$ & 1060.00 & 330.00 & 103.50 & 345.00 & 185.00 & 351.00 & 194.00 \\
\hline $\mathrm{La}$ & 36.00 & 33.30 & 15.70 & 12.00 & 12.50 & 22.00 & 21.90 \\
\hline $\mathrm{Ce}$ & 83.2 & 79.7 & 39.6 & 30.0 & 31.9 & 51.6 & 51.3 \\
\hline $\operatorname{Pr}$ & 10.90 & 10.85 & 5.49 & 4.43 & 4.64 & 7.11 & 7.01 \\
\hline $\mathrm{Nd}$ & 48.40 & 49.60 & 26.40 & 21.40 & 22.30 & 32.80 & 31.50 \\
\hline $\mathrm{Sm}$ & 11.10 & 12.45 & 6.86 & 5.81 & 6.14 & 8.68 & 8.48 \\
\hline $\mathrm{Eu}$ & 3.34 & 3.77 & 1.73 & 1.98 & 1.87 & 2.52 & 2.37 \\
\hline Gd & 10.80 & 13.85 & 7.13 & 6.49 & 6.64 & 9.38 & 9.34 \\
\hline $\mathrm{Tb}$ & 1.59 & 2.16 & 1.12 & 1.06 & 1.12 & 1.59 & 1.47 \\
\hline Dy & 9.45 & 13.45 & 6.91 & 6.31 & 6.97 & 9.62 & 9.53 \\
\hline Ho & 1.96 & 2.59 & 1.35 & 1.32 & 1.36 & 2.00 & 1.90 \\
\hline Er & 5.12 & 7.42 & 3.70 & 3.50 & 3.83 & 5.93 & 5.59 \\
\hline $\mathrm{Tm}$ & 0.74 & 1.11 & 0.53 & 0.51 & 0.51 & 0.78 & 0.79 \\
\hline $\mathrm{Yb}$ & 4.44 & 6.48 & 3.29 & 3.12 & 3.44 & 5.12 & 4.96 \\
\hline $\mathrm{Lu}$ & 0.65 & 0.99 & 0.45 & 0.43 & 0.50 & 0.76 & 0.72 \\
\hline $\mathrm{Rb}$ & 17.5 & 19.0 & 12.2 & 9.4 & 15.1 & 27.6 & 26.9 \\
\hline $\mathrm{Sr}$ & 445.0 & 266.0 & 45.9 & 261.0 & 223.0 & 172.5 & 176.0 \\
\hline Cs & 8.44 & 2.05 & 1.88 & 3.15 & 0.55 & 1.23 & 0.99 \\
\hline $\mathrm{Hf}$ & 7.3 & 8.5 & 5.3 & 4.3 & 4.7 & 6.7 & 6.9 \\
\hline $\mathrm{Ta}$ & 1.7 & 2.0 & 0.7 & 0.6 & 0.6 & 1.5 & 1.4 \\
\hline Th & 5.03 & 5.51 & 2.27 & 1.55 & 1.74 & 3.02 & 3.17 \\
\hline $\mathrm{U}$ & 1.26 & 1.17 & 0.50 & 0.45 & 0.45 & 0.93 & 0.87 \\
\hline $\mathrm{Y}$ & 48.9 & 72.7 & 32.6 & 33.1 & 34.8 & 50.9 & 50.4 \\
\hline $\mathrm{Zr}$ & 271 & 352 & 191 & 159 & 169 & 251 & 252 \\
\hline $\mathrm{Sc}$ & 30 & 31 & 48 & 39 & 38 & 38 & 38 \\
\hline $\mathrm{Pb}$ & 5 & 4 & 4 & - & - & - & - \\
\hline
\end{tabular}




\begin{tabular}{|c|c|c|c|c|c|c|c|}
\hline $\begin{array}{l}\text { Sample } \\
\text { Suite } \\
\end{array}$ & $\begin{array}{r}\text { AX85-251 } \\
\text { Isachsen } \\
\end{array}$ & $\begin{array}{r}\text { AX85-252 } \\
\text { Isachsen } \\
\end{array}$ & $\begin{array}{r}\text { AX85-260 } \\
\text { Isachsen } \\
\end{array}$ & $\begin{array}{r}\text { AX85-261 } \\
\text { Isachsen } \\
\end{array}$ & $\begin{array}{r}\text { AX85-262 } \\
\text { Isachsen } \\
\end{array}$ & $\begin{array}{r}\text { AX85-263 } \\
\text { Isachsen } \\
\end{array}$ & $\begin{array}{r}\text { AX85-264 } \\
\text { Isachsen } \\
\end{array}$ \\
\hline $\mathrm{SiO} 2(\mathrm{wt} \%)$ & 39.7 & 37.7 & 48.3 & 48.3 & 40.4 & 48.7 & 50.5 \\
\hline $\mathrm{TiO} 2$ & 2.60 & 2.02 & 2.30 & 2.22 & 2.31 & 2.27 & 2.04 \\
\hline $\mathrm{A} 12 \mathrm{O} 3$ & 15.30 & 11.25 & 14.05 & 14.10 & 15.05 & 14.15 & 12.70 \\
\hline $\mathrm{Fe} 2 \mathrm{O} 3 \mathrm{t}$ & 14.60 & 12.05 & 13.25 & 12.85 & 11.95 & 12.85 & 13.70 \\
\hline $\mathrm{MnO}$ & 0.12 & 0.25 & 0.21 & 0.18 & 0.26 & 0.18 & 0.20 \\
\hline $\mathrm{MgO}$ & 8.29 & 2.77 & 5.51 & 5.77 & 3.05 & 5.86 & 5.31 \\
\hline $\mathrm{CaO}$ & 5.60 & 14.90 & 10.65 & 10.65 & 13.80 & 10.55 & 9.72 \\
\hline $\mathrm{Na} 2 \mathrm{O}$ & 4.07 & 2.14 & 2.31 & 2.27 & 2.21 & 2.26 & 2.23 \\
\hline $\mathrm{K} 2 \mathrm{O}$ & 0.31 & 0.10 & 0.35 & 0.24 & 0.14 & 0.25 & 0.27 \\
\hline $\mathrm{P} 2 \mathrm{O} 5$ & 0.25 & 0.23 & 0.22 & 0.20 & 0.21 & 0.21 & 0.21 \\
\hline LOI & 8.98 & 15.65 & 1.81 & 1.91 & 10.10 & 1.84 & 1.83 \\
\hline Total & 99.88 & 99.11 & 99.04 & 98.76 & 99.55 & 99.20 & 98.77 \\
\hline$* * \mathrm{Mg} \#$ & 0.57 & 0.35 & 0.49 & 0.51 & 0.37 & 0.52 & 0.47 \\
\hline $\mathrm{V}(\mathrm{ppm})$ & 454.00 & 347.00 & 352.00 & 350.00 & 355.00 & 346.00 & 370.00 \\
\hline $\mathrm{Cr}$ & 110 & 70 & 100 & 100 & 110 & 100 & 60 \\
\hline Co & 44.00 & 34.00 & 44.00 & 42.00 & 44.00 & 44.00 & 46.00 \\
\hline $\mathrm{Ni}$ & 55 & 45 & 70 & 70 & 72 & 69 & 52 \\
\hline $\mathrm{Zn}$ & 120 & 18 & 106 & 102 & 98 & 105 & 121 \\
\hline $\mathrm{Nb}$ & 9.7 & 7.7 & 10.1 & 9.8 & 10.0 & 10.0 & 10.1 \\
\hline $\mathrm{Ba}$ & 61.80 & 113.50 & 238.00 & 199.50 & 129.50 & 234.00 & 154.00 \\
\hline $\mathrm{La}$ & 11.20 & 10.30 & 12.90 & 12.70 & 13.70 & 12.40 & 14.90 \\
\hline $\mathrm{Ce}$ & 29.8 & 26.2 & 31.9 & 30.9 & 33.2 & 30.8 & 36.3 \\
\hline $\operatorname{Pr}$ & 4.40 & 3.77 & 4.46 & 4.31 & 4.71 & 4.27 & 5.04 \\
\hline $\mathrm{Nd}$ & 20.60 & 18.20 & 22.00 & 20.70 & 21.70 & 20.80 & 23.90 \\
\hline $\mathrm{Sm}$ & 5.72 & 4.90 & 5.60 & 5.83 & 5.77 & 5.44 & 6.12 \\
\hline $\mathrm{Eu}$ & 1.62 & 1.56 & 1.82 & 1.79 & 1.87 & 1.79 & 1.72 \\
\hline $\mathrm{Gd}$ & 5.69 & 5.34 & 6.04 & 5.80 & 6.39 & 6.03 & 6.73 \\
\hline $\mathrm{Tb}$ & 1.02 & 0.88 & 0.99 & 0.93 & 1.01 & 0.95 & 1.11 \\
\hline Dy & 6.18 & 5.63 & 5.87 & 5.46 & 6.03 & 5.66 & 7.02 \\
\hline Ho & 1.22 & 1.12 & 1.15 & 1.16 & 1.18 & 1.09 & 1.36 \\
\hline Er & 3.38 & 2.99 & 3.03 & 3.01 & 3.10 & 3.02 & 3.91 \\
\hline $\mathrm{Tm}$ & 0.49 & 0.46 & 0.40 & 0.43 & 0.42 & 0.42 & 0.57 \\
\hline $\mathrm{Yb}$ & 2.94 & 2.74 & 2.61 & 2.45 & 2.47 & 2.51 & 3.57 \\
\hline $\mathrm{Lu}$ & 0.41 & 0.38 & 0.40 & 0.36 & 0.35 & 0.35 & 0.53 \\
\hline $\mathrm{Rb}$ & 6.6 & 1.1 & 9.9 & 4.8 & 1.4 & 5.2 & 10.3 \\
\hline $\mathrm{Sr}$ & 186 & 229 & 322 & 335 & 352 & 348 & 227 \\
\hline Cs & 0.48 & 0.22 & 0.35 & 0.17 & 0.04 & 0.25 & 0.83 \\
\hline $\mathrm{Hf}$ & 5.0 & 3.6 & 4.4 & 4.2 & 4.3 & 4.2 & 4.8 \\
\hline $\mathrm{Ta}$ & 0.6 & 0.5 & 0.7 & 0.6 & 0.6 & 0.6 & 0.7 \\
\hline Th & 1.77 & 1.49 & 1.82 & 1.73 & 1.84 & 1.75 & 2.94 \\
\hline $\mathrm{U}$ & 0.44 & 0.35 & 0.37 & 0.41 & 0.60 & 0.38 & 0.77 \\
\hline Y & 30.5 & 28.6 & 29.4 & 29.1 & 30.5 & 29.4 & 36.2 \\
\hline $\mathrm{Zr}$ & 165 & 135 & 153 & 149 & 155 & 152 & 174 \\
\hline $\mathrm{Sc}$ & 41 & 32 & 30 & 30 & 30 & 30 & 37 \\
\hline $\mathrm{Pb}$ & 2 & - & - & - & - & - & - \\
\hline
\end{tabular}




\begin{tabular}{|c|c|c|c|c|}
\hline $\begin{array}{l}\text { Sample } \\
\text { Suite }\end{array}$ & $\begin{array}{r}\text { AX85-265 } \\
\text { Isachsen } \\
\end{array}$ & $\begin{array}{r}\text { AX85-266 } \\
\text { Isachsen } \\
\end{array}$ & $\begin{array}{r}\text { AX85-267 } \\
\text { Isachsen } \\
\end{array}$ & $\begin{array}{r}\text { AX85-268 } \\
\text { Isachsen }\end{array}$ \\
\hline $\mathrm{SiO} 2(\mathrm{wt} \%)$ & 38.3 & 48.0 & 50.1 & 49.9 \\
\hline $\mathrm{TiO} 2$ & 2.17 & 1.97 & 2.58 & 2.17 \\
\hline $\mathrm{A} 12 \mathrm{O} 3$ & 14.20 & 12.90 & 12.95 & 12.50 \\
\hline $\mathrm{Fe} 2 \mathrm{O} 3 \mathrm{t}$ & 11.95 & 14.80 & 15.15 & 15.30 \\
\hline $\mathrm{MnO}$ & 0.22 & 0.22 & 0.22 & 0.21 \\
\hline $\mathrm{MgO}$ & 2.59 & 4.83 & 4.36 & 4.68 \\
\hline $\mathrm{CaO}$ & 15.00 & 9.72 & 8.59 & 9.38 \\
\hline $\mathrm{Na} 2 \mathrm{O}$ & 2.08 & 2.39 & 2.94 & 2.52 \\
\hline $\mathrm{K} 2 \mathrm{O}$ & 0.22 & 0.73 & 0.68 & 0.34 \\
\hline $\mathrm{P} 2 \mathrm{O} 5$ & 0.25 & 0.22 & 0.29 & 0.21 \\
\hline LOI & 12.50 & 2.75 & 1.53 & 1.06 \\
\hline Total & 99.53 & 98.59 & 99.45 & 98.31 \\
\hline$* * \mathrm{Mg} \#$ & 0.34 & 0.43 & 0.40 & 0.42 \\
\hline $\mathrm{V}(\mathrm{ppm})$ & 393.00 & 357.00 & 498.00 & 458.00 \\
\hline $\mathrm{Cr}$ & 70 & 70 & 20 & 40 \\
\hline Co & 49.00 & 43.00 & 40.00 & 47.00 \\
\hline $\mathrm{Ni}$ & 61 & 51 & 27 & 46 \\
\hline $\mathrm{Zn}$ & 123 & 113 & 133 & 130 \\
\hline $\mathrm{Nb}$ & 10.6 & 9.8 & 28.3 & 10.0 \\
\hline $\mathrm{Ba}$ & 100.50 & 160.50 & 248.00 & 131.00 \\
\hline $\mathrm{La}$ & 16.00 & 15.00 & 30.30 & 14.60 \\
\hline $\mathrm{Ce}$ & 38.5 & 36.2 & 66.7 & 35.2 \\
\hline $\operatorname{Pr}$ & 5.52 & 5.09 & 8.34 & 4.89 \\
\hline $\mathrm{Nd}$ & 25.40 & 22.90 & 36.00 & 23.50 \\
\hline Sm & 6.78 & 6.15 & 8.05 & 6.47 \\
\hline $\mathrm{Eu}$ & 1.94 & 1.74 & 2.17 & 1.93 \\
\hline $\mathrm{Gd}$ & 7.34 & 6.38 & 8.49 & 7.13 \\
\hline $\mathrm{Tb}$ & 1.20 & 1.13 & 1.36 & 1.28 \\
\hline Dy & 7.28 & 6.61 & 8.34 & 7.54 \\
\hline Ho & 1.54 & 1.34 & 1.74 & 1.62 \\
\hline $\mathrm{Er}$ & 4.26 & 4.01 & 5.04 & 4.82 \\
\hline $\mathrm{Tm}$ & 0.60 & 0.57 & 0.72 & 0.65 \\
\hline $\mathrm{Yb}$ & 3.96 & 3.46 & 4.69 & 3.88 \\
\hline $\mathrm{Lu}$ & 0.54 & 0.51 & 0.72 & 0.60 \\
\hline $\mathrm{Rb}$ & 3.2 & 22.7 & 21.5 & 15.0 \\
\hline $\mathrm{Sr}$ & 214 & 200 & 244 & 195 \\
\hline $\mathrm{Cs}$ & 0.12 & 0.35 & 1.34 & 1.09 \\
\hline $\mathrm{Hf}$ & 5.3 & 5.0 & 7.0 & 4.8 \\
\hline $\mathrm{Ta}$ & 0.7 & 0.6 & 1.8 & 0.6 \\
\hline Th & 3.01 & 2.85 & 4.48 & 2.98 \\
\hline $\mathrm{U}$ & 0.83 & 0.77 & 1.27 & 0.78 \\
\hline Y & 39.0 & 35.7 & 45.3 & 40.2 \\
\hline $\mathrm{Zr}$ & 192 & 176 & 256 & 171 \\
\hline $\mathrm{Sc}$ & 39 & 36 & 36 & 41 \\
\hline $\mathrm{Pb}$ & 2 & - & 2 & - \\
\hline
\end{tabular}




\section{Analysis of internal standard 10-LT-o5}

ALS Laboratories data and statistics of internal Standard 10-LT-05 from Lake Tahoe, CA. Uncert $=$ uncertainty.

\begin{tabular}{|c|c|c|c|c|}
\hline $\begin{array}{l}\text { Standard } \\
\text { ID }\end{array}$ & $\begin{array}{r}\text { 10-LT-05 } \\
\text { Batch 1 }\end{array}$ & $\begin{array}{r}\text { 10-LT-05 } \\
\text { Batch } 2\end{array}$ & $\begin{array}{r}10-\mathrm{LT}-05 \\
14 \text { run } \\
\text { average }\end{array}$ & $\begin{array}{l}\text { 10-LT-05 } \\
1 \sigma \text { uncert. }\end{array}$ \\
\hline $\begin{array}{l}\mathrm{SiO} 2 \\
(\%)\end{array}$ & 48.1 & 47.9 & 49.25 & 0.49 \\
\hline $\mathrm{TiO} 2$ & 1.48 & 1.48 & 1.47 & 0.03 \\
\hline $\mathrm{A} 12 \mathrm{O} 3$ & 17.9 & 17.8 & 17.975 & 0.20 \\
\hline $\mathrm{Fe} 2 \mathrm{O} 3$ & 9.46 & 9.46 & 9.615 & 0.11 \\
\hline $\mathrm{MnO}$ & 0.14 & 0.15 & 0.145 & 0.00 \\
\hline $\mathrm{MgO}$ & 6.51 & 6.68 & 6.755 & 0.09 \\
\hline $\mathrm{CaO}$ & 9.51 & 9.72 & 9.725 & 0.15 \\
\hline $\mathrm{Na} 2 \mathrm{O}$ & 3.6 & 3.59 & 3.62 & 0.12 \\
\hline $\mathrm{K} 2 \mathrm{O}$ & 1.01 & 1.02 & 1.035 & 0.01 \\
\hline $\mathrm{P} 2 \mathrm{O} 5$ & 0.38 & 0.39 & 0.38 & 0.01 \\
\hline LOI & 1.06 & 0.9 & 0.9 & 0.17 \\
\hline Total & 99.35 & 99.29 & 101.07 & 0.64 \\
\hline $\mathrm{V}(\mathrm{ppm})$ & 181 & 185 & 164.6 & 8.29 \\
\hline $\mathrm{Cr}$ & 180 & 210 & 192 & 11.63 \\
\hline Co & 41 & 39 & 37.75 & 1.60 \\
\hline $\mathrm{Ni}$ & 118 & 108 & 115.75 & 4.79 \\
\hline $\mathrm{Zn}$ & 90 & 90 & 92.75 & 2.62 \\
\hline $\mathrm{Nb}$ & 11.4 & 10.2 & 10.78 & 0.30 \\
\hline $\mathrm{Ba}$ & 554 & 513 & 530.4 & 15.84 \\
\hline $\mathrm{La}$ & 24.4 & 22.2 & 21.82 & 0.81 \\
\hline $\mathrm{Ce}$ & 52.7 & 47.8 & 47.14 & 1.97 \\
\hline $\operatorname{Pr}$ & 6.83 & 5.96 & 6.072 & 0.26 \\
\hline $\mathrm{Nd}$ & 28 & 25.1 & 25.52 & 0.93 \\
\hline $\mathrm{Sm}$ & 4.98 & 4.84 & 5.046 & 0.25 \\
\hline $\mathrm{Eu}$ & 1.62 & 1.69 & 1.578 & 0.05 \\
\hline $\mathrm{Gd}$ & 4.83 & 4.89 & 4.458 & 0.23 \\
\hline $\mathrm{Tb}$ & 0.7 & 0.68 & 0.656 & 0.03 \\
\hline Dy & 3.71 & 3.55 & 3.508 & 0.14 \\
\hline Ho & 0.75 & 0.73 & 0.708 & 0.04 \\
\hline $\mathrm{Er}$ & 1.95 & 2.03 & 1.958 & 0.06 \\
\hline $\mathrm{Tm}$ & 0.26 & 0.28 & 0.256 & 0.02 \\
\hline $\mathrm{Yb}$ & 1.59 & 1.77 & 1.618 & 0.11 \\
\hline $\mathrm{Lu}$ & 0.27 & 0.28 & 0.246 & 0.01 \\
\hline $\mathrm{Rb}$ & 13.1 & 12.7 & 12.78 & 0.32 \\
\hline $\mathrm{Sr}$ & 913 & 951 & 934.6 & 16.02 \\
\hline Cs & 0.25 & 0.21 & 0.22 & 0.03 \\
\hline $\mathrm{Hf}$ & 3.7 & 3.6 & 3.54 & 0.15 \\
\hline $\mathrm{Ta}$ & 0.6 & 0.6 & 0.62 & 0.05 \\
\hline Th & 2.37 & 2.08 & 1.984 & 0.09 \\
\hline $\mathrm{U}$ & 0.46 & 0.66 & 0.55 & 0.05 \\
\hline $\mathrm{Y}$ & 19.4 & 19.1 & 18.5 & 0.57 \\
\hline $\mathrm{Zr}$ & 160 & 155 & 145.8 & 5.17 \\
\hline $\mathrm{Sc}$ & 16 & 16 & 16 & 0.99 \\
\hline $\mathrm{Pb}$ & $<2$ & 2 & 4.7 & 1.64 \\
\hline
\end{tabular}




\section{Appendix 3: Sm-Nd Isotopes}

Notes:

1. The foregoing table is a reproduction of the second supplementary table in (Kingsbury et al., 2016) which is a paper that also serves as Chapter 3 in this thesis - refer to the preface for more information.

2. ${ }^{*} \mathrm{NdPBC}=$ Neodymium procedural blank code. Batch $\mathrm{A}=38 \mathrm{pg} ;$ Batch $\mathrm{B}=8 \mathrm{pg}$.

3. $\wedge^{\wedge}$ Uncertainty (next page) is relative to ${ }^{143} \mathrm{Nd} /{ }^{144} \mathrm{Nd}(\mathrm{t})$

\begin{tabular}{|c|c|c|c|c|c|}
\hline Sample & Suite & $\begin{array}{r}\text { Age } \\
\text { Correction } \\
(\mathrm{Ma}) \\
\end{array}$ & $\mathrm{NdPBC}^{*}$ & $\begin{array}{l}\mathrm{Nd} \\
(\mathrm{ppm})\end{array}$ & $143 \mathrm{Nd} / 144 \mathrm{Nd}(0)$ \\
\hline 13_WJA_C018_A1 & S. Fiord & 105 & $A$ & 21.50 & 0.512844 \\
\hline 13_WJA_C018_A2 & S. Fiord & 105 & A & 22.44 & 0.512841 \\
\hline 13_WJA_C027_A2 & S. Fiord & 105 & A & 18.54 & 0.512723 \\
\hline 13_WJA_C028_A2 & S. Fiord & 105 & $A$ & 58.83 & 0.512730 \\
\hline 13_WJA_C032_A & S. Fiord & 105 & A & 33.66 & 0.512808 \\
\hline 13_CK_011 & S. Fiord & 105 & A & 36.61 & 0.512665 \\
\hline 13_CK_016 & S. Fiord & 105 & A & 35.23 & 0.512666 \\
\hline 13_CK_018 & S. Fiord & 105 & A & 28.59 & 0.512719 \\
\hline 13_WJA_C022_A2 & Isachsen & 105 & A & 27.53 & 0.512833 \\
\hline 13_WJA_CO22_C2 & Isachsen & 105 & A & 16.57 & 0.512718 \\
\hline AX85-241 & Isachsen & 120 & B & 51.32 & 0.512779 \\
\hline AX85-242 & Isachsen & 120 & B & 50.45 & 0.512773 \\
\hline$A \times 85-245$ & Isachsen & 120 & B & 22.53 & 0.512864 \\
\hline AX85-246 & Isachsen & 120 & B & 23.24 & 0.512862 \\
\hline$A \times 85-250$ & Isachsen & 120 & B & 34.21 & 0.512907 \\
\hline AX85-262 & Isachsen & 120 & B & 22.56 & 0.512896 \\
\hline AX85-263 & Isachsen & 120 & B & 21.71 & 0.512890 \\
\hline AX85-265 & Isachsen & 120 & B & 26.65 & 0.512783 \\
\hline AX85-267 & Isachsen & 120 & B & 36.94 & 0.512825 \\
\hline AX85-268 & Isachsen & 120 & B & 23.66 & 0.512789 \\
\hline
\end{tabular}

Table continues next page 
Table continued from previous page.

\begin{tabular}{|c|c|c|c|c|c|}
\hline Sample & $\begin{array}{l}\text { Sm } \\
\text { (ppm) }\end{array}$ & $143 \mathrm{Nd} / 144 \mathrm{Nd}(\mathrm{t})$ & $147 \mathrm{Sm} / 143 \mathrm{Nd}$ & $\varepsilon N d(t)$ & $\begin{array}{l}\text { Uncertainty^ } \\
(2 \sigma)\end{array}$ \\
\hline 13_WJA_C018_A1 & 5.71 & 0.512733 & 0.16068 & 4.5 & 0.000011 \\
\hline 13_WJA_C018_A2 & 5.97 & 0.512730 & 0.16083 & 4.4 & 0.000011 \\
\hline 13_WJA_C027_A2 & 4.69 & 0.512618 & 0.15301 & 2.2 & 0.000010 \\
\hline 13_WJA_C028_A2 & 14.07 & 0.512631 & 0.14455 & 2.5 & 0.000010 \\
\hline 13_WJA_C032_A & 8.58 & 0.512702 & 0.15419 & 3.9 & 0.000011 \\
\hline 13_CK_011 & 8.70 & 0.512567 & 0.14359 & 1.2 & 0.000010 \\
\hline 13_CK_016 & 8.39 & 0.512567 & 0.14391 & 1.3 & 0.000010 \\
\hline 13_CK_018 & 6.79 & 0.512620 & 0.14354 & 2.3 & 0.000010 \\
\hline 13_WJA_C022_A2 & 7.82 & 0.512715 & 0.17174 & 4.1 & 0.000011 \\
\hline 13_WJA_C022_C2 & 4.34 & 0.512609 & 0.15844 & 2.1 & 0.000011 \\
\hline AX85-241 & 11.84 & 0.512669 & 0.13950 & 3.6 & 0.000010 \\
\hline AX85-242 & 11.61 & 0.512663 & 0.13915 & 3.5 & 0.000010 \\
\hline AX85-245 & 6.31 & 0.512731 & 0.16918 & 4.8 & 0.000011 \\
\hline AX85-246 & 6.49 & 0.512729 & 0.16874 & 4.8 & 0.000011 \\
\hline AX85-250 & 9.05 & 0.512781 & 0.15992 & 5.8 & 0.000011 \\
\hline AX85-262 & 6.11 & 0.512767 & 0.16372 & 5.5 & 0.000011 \\
\hline AX85-263 & 5.93 & 0.512761 & 0.16505 & 5.4 & 0.000011 \\
\hline AX85-265 & 7.18 & 0.512655 & 0.16290 & 3.3 & 0.000011 \\
\hline AX85-267 & 8.39 & 0.512717 & 0.13740 & 4.6 & 0.000010 \\
\hline AX85-268 & 6.57 & 0.512657 & 0.16790 & 3.4 & 0.000011 \\
\hline
\end{tabular}




\section{Appendix 4: Crustal composition model}

\section{Crustal modeling methodology}

Trace element and Nd isotopic crustal composition for the Sverdrup Basin, Franklin Mobile Belt and the cratonic proxy derived from Franklin units older than 450 Ma are compiled from datasets derived from (Patchett et al., 2004) in the case of the Sverdrup Basin and (Patchett et al., 1999) for the Franklin Mobile Belt and cratonic proxy. These formed the basis for crustal contamination models used in Chapter 3 (Kingsbury et al., 2016). For the Sverdrup Basin, units older than and including the Christopher Formation of 110 Ma (Patchett et al., 2004) were used in the calculation.

Calculating the estimated bulk composition of each crustal package: If we let $C_{E}$ represent the concentration of a certain element $E$ in a lithological unit $(L U)$, contained within a crustal package (Sverdrup Basin, Franklinian Mobile Belt and the cratonic proxy derived from the latter), then the average $(\bar{x})$ concentration of $\mathrm{E}$ in the crustal package concerned is represented by the general equation:

$$
C_{E}=\frac{\left[\left(\bar{x}_{L U_{1}}\right)+\left(\bar{x}_{L U_{2}}\right)+\left(\bar{x}_{L U_{3}}\right)+\cdots+\left(\bar{x}_{L U_{n}}\right)\right]}{n_{L U}}
$$

where $n$ is the number of lithological units measured by Patchett. This approach assumes that each individual sedimentary package has a sub-equal chance to contribute to the contamination of the mafic HALIP intrusive and extrusive for those rocks that show evidence of contamination. 


\section{Crustal modeling data:}

\begin{tabular}{|c|c|c|c|}
\hline \multirow[b]{2}{*}{ Element } & \multicolumn{3}{|c|}{$\begin{array}{c}\text { Crustal } \\
\text { Package }\end{array}$} \\
\hline & Sverdrup & Franklin & Cratonic \\
\hline $\mathrm{Li}$ & 71.86 & - & - \\
\hline $\mathrm{Be}$ & - & - & - \\
\hline Sc & 10.26 & 9.67 & 6.03 \\
\hline V & 95.33 & 103.57 & 21.73 \\
\hline $\mathrm{Rb}$ & 66.75 & 85.65 & 72.07 \\
\hline $\mathrm{Sr}$ & 258.82 & 137.65 & 427.06 \\
\hline Y & 21.91 & 17.61 & 14.47 \\
\hline $\mathrm{Zr}$ & 189.13 & 137.60 & 241.47 \\
\hline $\mathrm{Nb}$ & 11.85 & 8.36 & 6.24 \\
\hline Mo & 1.42 & 1.27 & 0.52 \\
\hline Cs & 3.98 & 3.95 & 1.11 \\
\hline $\mathrm{Ba}$ & 370.79 & 617.15 & 567.66 \\
\hline La & 31.03 & 27.28 & 25.91 \\
\hline $\mathrm{Ce}$ & 62.74 & 55.19 & 55.16 \\
\hline $\mathrm{Pr}$ & 7.32 & 6.51 & 6.33 \\
\hline $\mathrm{Nd}$ & 28.97 & 24.40 & 23.75 \\
\hline Sm & 5.30 & 4.41 & 4.04 \\
\hline $\mathrm{Eu}$ & 1.09 & 0.84 & 0.88 \\
\hline $\mathrm{Gd}$ & 4.76 & 3.71 & 3.29 \\
\hline $\mathrm{Tb}$ & 0.68 & 0.52 & 0.43 \\
\hline Dy & 4.17 & 3.25 & 2.64 \\
\hline Ho & 0.83 & 0.66 & 0.51 \\
\hline $\mathrm{Er}$ & 2.41 & 1.87 & 1.40 \\
\hline $\mathrm{Yb}$ & 2.39 & 1.81 & 1.26 \\
\hline Lu & 0.36 & 0.28 & 0.20 \\
\hline $\mathrm{Hf}$ & 5.66 & 3.73 & 6.89 \\
\hline $\mathrm{Ta}$ & 0.95 & 0.56 & 0.38 \\
\hline $\mathrm{Tl}$ & 0.51 & 0.54 & 0.38 \\
\hline $\mathrm{Pb}$ & 18.96 & 11.16 & 13.80 \\
\hline $\mathrm{Bi}$ & 0.21 & 0.24 & 0.10 \\
\hline Th & 9.73 & 7.40 & 8.33 \\
\hline U & 2.69 & 2.09 & 1.54 \\
\hline $\mathrm{La} / \mathrm{Sm}$ & 6.09 & 7.08 & 6.57 \\
\hline $\mathrm{Ba} / \mathrm{Nb}$ & 36.08 & 82.69 & 98.33 \\
\hline $\mathrm{Nb} / \mathrm{La}$ & 0.37 & 0.36 & 0.23 \\
\hline $\mathrm{Nb} / \mathrm{U}$ & 4.40 & 3.89 & 4.17 \\
\hline Th/La & 0.32 & 0.30 & 0.33 \\
\hline $\mathrm{Ba} / \mathrm{Th}$ & 39.96 & 93.63 & 73.69 \\
\hline$\varepsilon \mathrm{Nd}_{\mathrm{T}-105 \mathrm{Ma}}$ & -11.1 & -14.0 & -26.7 \\
\hline
\end{tabular}




\section{Appendix 5: U-Pb geochronology data}

Notes:

1. The U-Pb geochronology table (next page) is associated with Chapter 4 of this thesis.

2. EARTHTIME tracer ET535 $\left({ }^{205} \mathrm{~Pb}^{233-235} \mathrm{U}\right)$ was used.

3. Th/U calculated from radiogenic ${ }^{208} \mathrm{~Pb} /{ }^{206} \mathrm{~Pb}$ ratio and ${ }^{207} \mathrm{~Pb} /{ }^{206} \mathrm{~Pb}$ age assuming concordance.

4. $\mathrm{Pb}_{\text {total }}$ is total amount of $\mathrm{Pb}$ excluding blank.

5. $\mathrm{PbC}$ is total amount of common $\mathrm{Pb}$ in pictograms; assigned the isotopic. composition of laboratory blank.

6. ${ }^{206} \mathrm{~Pb} /{ }^{204} \mathrm{~Pb}$ corrected for fractionation and common $\mathrm{Pb}$ in the spike.

7. $\mathrm{Pb} / \mathrm{U}$ ratios corrected for fractionation, common $\mathrm{Pb}$ in the spike, and blank.

8. Correction for ${ }^{230} \mathrm{Th}$ disequilibrium in ${ }^{206} \mathrm{~Pb} /{ }^{238} \mathrm{~Pb}$ and ${ }^{207} \mathrm{~Pb} /{ }^{206} \mathrm{~Pb}$ assuming $\mathrm{Th} / \mathrm{U}$ of 4.2 in the magma.

9. Disc $=$ percentage discordance for the ${ }^{207} \mathrm{~Pb} /{ }^{206} \mathrm{~Pb}$ age.

10. Error Corr $=$ correlation coefficient of $\mathrm{X}-\mathrm{Y}$ errors on the concordia plot. 


\begin{tabular}{|c|c|c|c|c|c|c|}
\hline \multirow{2}{*}{$\begin{array}{l}\text { Sample ID } \\
\text { Analysis \# }\end{array}$} & \multicolumn{3}{|c|}{ 13-СК-16 } & \multicolumn{3}{|c|}{ 13-WJA-C028-A2 } \\
\hline & B1 & $B 2$ & B3 & B1 & $B 2$ & B3 \\
\hline $\mathrm{Th} / \mathrm{U}$ & 0.13 & 0.16 & 0.10 & 0.01 & 0.09 & 0.07 \\
\hline $\mathrm{Pb}_{\text {total }}(\mathrm{pg})$ & 1.0 & 1.0 & 2.1 & 2.4 & 6.3 & 3.8 \\
\hline $\mathrm{PbC}(\mathrm{pg})$ & 0.40 & 0.42 & 2.1 & 2.4 & 2.0 & 1.3 \\
\hline${ }^{206} \mathrm{~Pb} /{ }^{204} \mathrm{~Pb}$ (meas) & 188.8 & 186.5 & 84.5 & 87.7 & 240.4 & 226.0 \\
\hline${ }^{207} \mathrm{~Pb} /{ }^{235} \mathrm{U}$ & 0.1005 & 0.1024 & 0.1040 & 0.0925 & 0.0981 & 0.0995 \\
\hline $2 \sigma$ & 0.0084 & 0.0096 & 0.0197 & 0.0191 & 0.0057 & 0.0063 \\
\hline${ }^{206} \mathrm{~Pb} /{ }^{238} \mathrm{U}$ & 0.014879 & 0.014871 & 0.014861 & 0.015088 & 0.014938 & 0.014914 \\
\hline $2 \sigma$ & 0.000077 & 0.000086 & 0.000169 & 0.000168 & 0.000053 & 0.000056 \\
\hline Error Corr & 0.938 & 0.955 & 0.988 & 0.966 & 0.944 & 0.965 \\
\hline${ }^{207} \mathrm{~Pb} /{ }^{206} \mathrm{~Pb}$ & 0.0490 & 0.0499 & 0.0507 & 0.0444 & 0.0477 & 0.0484 \\
\hline $2 \sigma$ & 0.0039 & 0.0044 & 0.0091 & 0.0087 & 0.0026 & 0.0029 \\
\hline${ }^{206} \mathrm{~Pb} /{ }^{238} \mathrm{U}$ Age (Ma) & 95.21 & 95.16 & 95.10 & 96.53 & 95.58 & 95.43 \\
\hline $2 \sigma$ & 0.49 & 0.55 & 1.07 & 1.07 & 0.33 & 0.35 \\
\hline${ }^{207} \mathrm{~Pb} /{ }^{235} \mathrm{U}$ Age (Ma) & 97.2 & 99.0 & 100.4 & 89.8 & 95.1 & 96.3 \\
\hline $2 \sigma$ & 7.8 & 8.9 & 18.2 & 17.8 & 5.3 & 5.8 \\
\hline$\%$ Disc & 35 & 51 & 59 & 33 & -17 & 19 \\
\hline
\end{tabular}




\section{Appendix 6: Appendices References}

Kingsbury, C.G., Ernst, R.E., Cousens, B.L., and Williamson, M.-C., 2016, The High Arctic LIP in Canada: Trace element and Sm-Nd Isotopic evidence for the role of mantle heterogeneity and crustal assimilation: Norwegian Journal of Geology, v. 96, no. 2, p. 13-33.

Patchett, P.J., Embry, A.F., Ross, G.M., Beauchamp, B., Harrison, J.C., Mayr, U., Isachsen, C.E., Rosenberg, E.J., and Spence, G.O., 2004, Sedimentary Cover of the Canadian Shield through Mesozoic Time Reflected by Nd Isotopic and Geochemical Results for the Sverdrup Basin , Arctic Canada: The Journal of Geology, v. 112, no. 1, p. 39-57.

Patchett, P.J., Roth, M.A., Canale, B.S., de Freitas, T.A., Harrison, J.C., Embry, A.F., and Ross, G.M., 1999, Nd isotopes, geochemistry, and constraints on sources of sediments in the Franklinian mobile belt, Arctic Canada: Geological Society of America Bulletin, v. 111, no. 4, p. 578-589, doi: 10.1130/00167606(1999)111<0578:NIGACO>2.3.CO;2. 